Débora Consoni Gouveia

\title{
A AUTORIDADE PARENTAL NAS FAMÍLIAS RECONSTITUÍDAS
}

DISSERTAÇÃO DE MESTRADO

ORIENTADOR: PROFESSOR DOUTOR ROBERTO JOÃO ELIAS

FACULDADE DE DIREITO DA UNIVERSIDADE DE SÃO PAULO

SÃO PAULO

2010 
DÉBORA CONSONI GOUVEIA

\section{A AUTORIDADE PARENTAL NAS FAMÍLIAS RECONSTITUÍDAS}

DisSERTAÇÃO DE MESTRADO APRESENTADA aO Departamento de Direito Civil DA FACUlDADE DE DiREITO DA UNIVERSIDADE DE SÃo PAUlo, COMO REQUiSito PARCIAL PARA OBTENÇÃO DO TÍTUlO DE MESTRE.

ORIENTADOR: PROFESSOR DOUTOR ROBERTO JOÃo ELIAS. 
BANCA EXAMINADORA 
AOS MEUS QUERIDOS PAIS POR TODO CARINHO, APOIO, ATENÇÃO, E, ESPECIALMENTE, POR MINHA EDUCAÇÃO E PELOS VALORES TRANSMITIDOS.

AO MEU QUERIDO MARIDO, CASSIO CAMBI GOUVEIA, PELO AMOR, DEDICAÇÃO E COMPREENSÃO, PELO CONSTANTE INCENTIVO E, PRINCIPALMENTE, POR SEMPRE ACREDITAR E ME FAZER ACREDITAR QUE TUDO É POSSÍVEL. AO PROFESSOR ORIENTADOR DOUTOR ROBERTO JOÃO ELIAS PELA CONFIANÇA DEPOSITADA. 


\section{RESUMO}

O objetivo do presente trabalho é demonstrar a possibilidade de atuação dos pais afins nas famílias reconstituídas, assim entendidas como aquelas formadas em segundas núpcias, em que pelo menos um dos cônjuges ou companheiro possui filhos de uma união anterior, de forma complementar e subsidiária aos pais biológicos, com vista a integrar a parentalidade, visando ao melhor interesse da criança e do adolescente à luz da Constituição Federal, do Estatuto da Criança e do Adolescente e do Código Civil. Com base no princípio do valor jurídico do afeto e no instituto da paternidade socioafetiva, busca-se evidenciar a importância do exercício da autoridade parental, de forma complementar, pelos pais afins nos lares reconstituídos. A convivência, os cuidados diários, a dedicação fazem nascer entre os integrantes das famílias reconstituídas vínculos de afetividade, que se revelam importantes e relevantes para o pleno desenvolvimento do menor. E apenas o pleno exercício da autoridade parental nas famílias reconstituídas permitirá uma adequada estruturação familiar, com atribuição de funções definidas aos membros integrantes desta complexa estrutura familiar, onde os papéis não são definidos e a legislação em nada orienta o comportamento, especialmente, dos pais afins. Para esta plena integração e bom funcionamento da estrutura familiar reconstituída, tendo em vista o melhor interesse do menor, objetiva-se demonstrar a necessidade de legitimação da conduta dos pais afins, no âmbito da família, hoje, vedada pelo ordenamento jurídico brasileiro.

PALAVRAS-CHAVE: Direito de Família - novas estruturas familiares famílias reconstituídas - autoridade parental 


\begin{abstract}
The purpose of this study is to demonstrate the possibility of actions of step parents in reconstituted families, those formed in remarriages in which at least one spouse or partner has children from a previous union, in a complementary and subsidiary way to biological parents with the purpose to integrate parenthood, aiming for the best interests of children and adolescents in the light of the Federal Constitution, the Statute of Children and Adolescents and the Civil Code. Based on the principle of the legal value of affection and the institute of socio-affective parenthood, it is sought to highlight the importance of the exercise of parental authority, as complementary, by the step parents in the rebuilt homes. Coexistence, the daily care and dedication create among the members of reconstituted families ties of affection which are important and relevant to the full development of the child. Only the full exercise of parental authority in reconstituted families will allow a proper family structuring, with attribution of tasks to members of this complex family structure, in which nowadays roles are not defined and the legislation does nothing to guide behavior, especially of step parentes. For this full integration and smooth functioning of the reconstituted family structure, in view of the best interests of the child, the objective is to demonstrate the need to legitimize the conduct of the step parentes in the family, today prohibited under Brazilian law.
\end{abstract}

KEY-WORDS: Family law - families structures - reconstituted family parental authority. 


\section{A AUTORIDADE PARENTAL NAS FAMÍLIAS RECONSTITUÍDAS}

\section{SUMÁRIO}

I - Introdução

II - A Família: evolução

1. Evolução do instituto 03

2. A família no ordenamento jurídico brasileiro ..................................... 14

3. A família pós-moderna.................................................................... 28

III - As novas estruturas familiares: famílias reconstituídas

1. A família plural constitucionalizada ..................................................... 35

2. A significativa expressão da família reconstituída ................................. 39

3. Família reconstituída: uma estrutura complexa ................................... 43 IV - Parentesco.

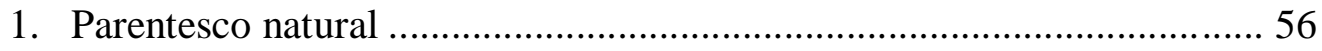

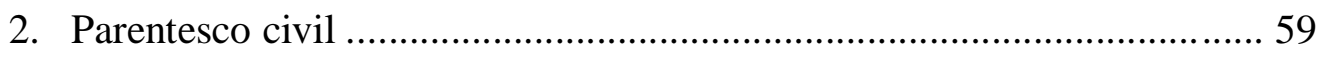

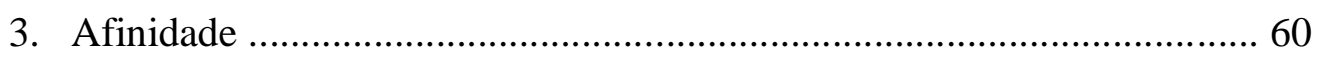

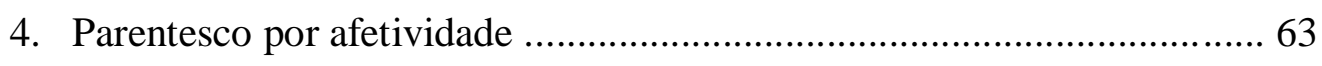

V - Paternidade, filiação e afeto.

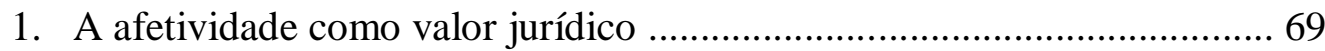

2. Paternidade: proteção dos filhos na Constituição Federal de 1988........... 85

3. A paternidade e seu conteúdo afetivo. Posse de estado de filho ............. 97

4. Conceito contemporâneo de paternidade .............................................. 105

5. Paternidade socioafetiva. Reconhecimento e justificativas ................... 109

VI - Poder familiar ou autoridade parental?

1. Do pátrio poder ao poder familiar ....................................................... 126

2. Poder ou autoridade? ........................................... 129

3. O exercício da autoridade parental e suas características ...................... 134

VII - Autoridade parental nas famílias reconstituídas

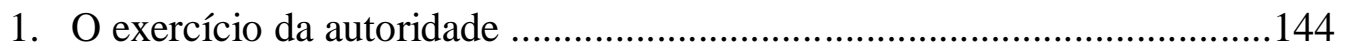

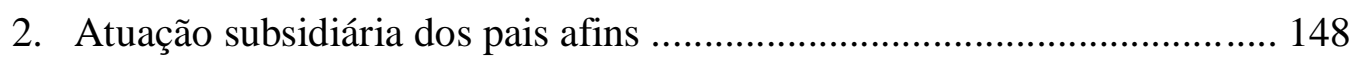

2.1. Atuação dos pais afins quando os pais biológicos são ativos ............. 154

2.1.1. Estabelecimento do vínculo com os pais afins em razão da idade ..... 156 
2.3. A questão econômica como influência na qualidade do vínculo familiar 160

3. Crítica ao artigo 1.636 do CCB/2002

VIII - Legislação estrangeira.

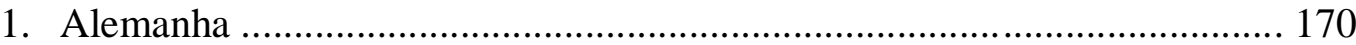

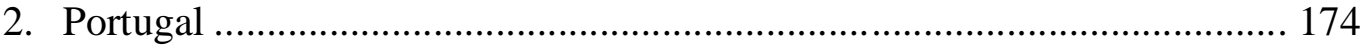

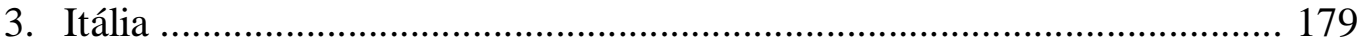

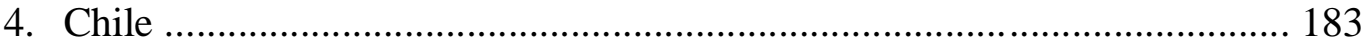

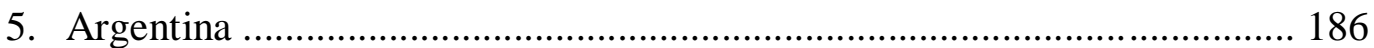

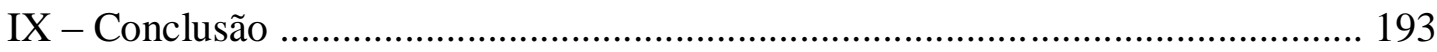

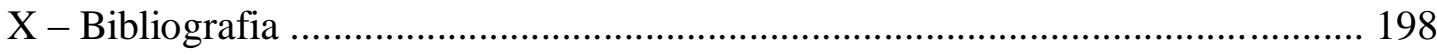





\section{I - INTRODUÇÃO}

A presente pesquisa tem como objetivo estudar a autoridade parental nas famílias reconstituídas, especialmente no tocante às funções dos pais socioafetivos, quando o pai biológico continua exercendo ativamente suas funções, em diferentes graus.

Ao longo do estudo pretende-se desenvolver maior reflexão sobre as questões jurídicas, sociais e psicológicas nas famílias reconstituídas, assim entendidas como famílias formadas em segundas núpcias em que pelo menos um dos cônjuges ou companheiros possua filho do relacionamento anterior, em especial sobre o tema da paternidade socioafetiva, visando ao melhor interesse da criança e do adolescente à luz da Constituição Federal, do Estatuto da Criança e do Adolescente e do Código Civil.

O instituto jurídico familiar identificado como paternidade socioafetiva, ainda não respaldado pela legislação civil em voga, mas já admitido pelos Tribunais do país, enquadrado como um fato social e, sendo integrado ao sistema de direito, concretizará a mais importante de todas as formas jurídicas de paternidade, em que seguirão como filhos legítimos os que descendem do amor e dos vínculos puros de espontânea afeição, tendo por vezes significado mais profundo que a verdade biológica.

O amor paterno, a convivência, os cuidados diários e a natural dedicação ao filho revelam uma verdade afetiva, uma paternidade que vai sendo construída pelo livre desejo de atuar em interação paterno-filial, formando laços sólidos e sinceros de afeto, em decorrência da solidariedade familiar, que não necessariamente estão presentes na filiação biológica. O estabelecimento de tal vínculo afetivo também se dá nas famílias reconstituídas entre pais e filhos afins, fato que permite o desenvolvimento da paternidade afetiva de forma complementar à paternidade biológica, quando o pai biológico está ativo.

O exercício pleno da autoridade parental nos lares reconstituídos permitirá uma adequada estruturação familiar, assim, tendo seus membros suas funções definidas, propiciarão melhores condições para o desenvolvimento dos menores, no seio da nova família.

Para todos esses caracteres citados, a nossa legislação civil nada aponta, pois, na medida em que não protegem a filiação por afeto, realmente não exerce a completa proteção dos entes familiares, não estimula os compromissos e nem as responsabilidades dentro das famílias reconstituídas. 
Dentro do tema acima apresentado, a pesquisa tem como objetivo demonstrar a importância dos vínculos de afetividade nas famílias reconstituídas para o pleno desenvolvimento do menor; diagnosticar as principais dificuldades no exercício da autoridade parental nas famílias reconstituídas; e, principalmente, evidenciar a falta de reconhecimento pelo direito brasileiro aos pais afins mediante a afirmação de certos direitos e responsabilidades. Para tanto serão utilizand0s os subsídios oferecidos pela Doutrina, Jurisprudência e pela legislação (interna e externa), sem abdicar da necessária interdisciplinaridade para o desenvolvimento do projeto, utilizando subsídios de diversas áreas do conhecimento além da jurídica. 


\section{II - A FAMÍLIA: EVOLUÇÃO.}

\section{EVOLUÇÃO DO INSTITUTO}

Não há no ordenamento jurídico um conceito de família e, dificilmente, será possível atribuir-lhe uma definição predeterminada, aplicável a todas às épocas e povos distintos. Isto porque, a família vive em constante transformação em razão de sua função, natureza e concepção.

A família, enquanto instituição, sempre esteve inserida no contexto histórico, político e social da civilização humana. A reunião de pessoas à volta de um núcleo familiar é das instituições mais antigas. A sua realização na história se deu e, atualmente se dá de inúmeras formas, diga-se, não estáticas, o que torna tão instigante e intrigante o seu estudo.

As pessoas mudam e assim mudam as suas aspirações, suas necessidades e seus ideais, contudo a família ainda permanece como base do agrupamento das pessoas, enquanto transmissora de valores e princípios. No entanto sua forma de organização, como veremos, se altera constante e significativamente nas diversas culturas e épocas

A família reflete diretamente cada momento histórico vivido pela humanidade, podendo ter sido estruturada por razões econômicas, políticas, sociais, religiosas, procriativas, afetivas, entre outras.

A alteração das características dos grupos familiares pode-se dar em função da época, da geografia, do desenvolvimento econômico, técnico e social, de classe social, da política e da evolução de idéias.

Nestas circunstâncias, Ricardo C. Perez Manrique lembra que não existe no direito internacional uma definição do conceito de família, não obstante inúmeros instrumentos internacionais a ele façam referência. Para o autor, os instrumentos internacionais, em linhas gerais, consagram princípios de proteção da família, da igualdade e da não discriminação e da autonomia familiar. Sendo que o conceito de família é mutante e está em contínuo processo de construção, desconstrução e nova formação. Cada época, com sua realidade social e seus parâmetros econômicos, políticos, morais e religiosos, reconhecerá formas predominantes de relações familiares ou de famílias propriamente ditas. Assim pode-se afirmar que a família se converteu em um centro de imputação 
jurídica em que se devem observar as normas de respeito e não discriminação de todos os seus integrantes - mulheres e filhos incluídos. ${ }^{1}$

Pois bem, a família, enquanto forma específica de agregação tem dinâmica própria, mas que é afetada pelos processos social, econômico e político. Por esta razão, a estrutura social é uma espécie de esqueleto sobre o qual a sociedade e suas operações estão fundadas. Supõe-se que, quando este muda, todo resto também tende a mudar, pois os contextos culturais e subculturais em que se está imerso, os contextos histórico, político, econômico, religioso, de meio ambiente, de peculiaridades de região, país ou hemisfério sustentam e compõem o universo relacional do indivíduo. ${ }^{2}$

Nesta linha, precisa a lição da professora Giselda Maria Fernandes Novaes Hironaka: "Mudam os homens. Mudam seus agrupamentos sociais. Mudam as instituições. Mudam os institutos jurídicos. Muda a família. Mudam as relações familiais não para serem outras, mas para desempenharem novos e distintos papéis." 3

Para Eduardo Bittar, a família está constantemente se modificando "pela erosão de valores, pela alteração de parâmetros de comportamento, pela decrepitude e pela inadequação das instituições aos desafios presentes, pelas mudanças socioeconômicas, pelas crises simultâneas que afetam diversos aspectos da vida organizada em sociedade, pela explosão de complexidade provocada pela emergência de novos conflitos socioinstitucionais, pela requalificação dinâmica dos modos de produção, pelas alterações nos modos tradicionais de se conceber o ferramental jurídico para a construção de regras sociais."

Relata a história a transformação da família através das diversas conotações a ela dada ao longo do tempo. Entre algumas, lembramos da família enquanto agrupamento religioso e político, da família clássica, da família moderna contemporânea e

\footnotetext{
1 "No existe em el derecho Internacional de los Derechos Humanos uma definición del concepto de familia, no obstante numerosos instrumentos internacionales hacen referencia al mismo". E continua o autor: "Los instrumentos internacionales em líneas generales consagran los princípios de Protección de la Familia, de Igualdad y No Discriminación y Autonomia Familiar". Concluindo, que, "el concepto de Familia es cambiante, em continuo proceso de construcción, desconstucción y nueva formación. Cada época, com su realidad social y sus parâmetros econômicos, políticos, morales y religiosos reconocerá formas predominantes de relaciones familiares o de famílias propriamente dichas. Se puede afirmar que la Familia se há convertido así en un centro de imputación jurídica em cuyo desarrollo deben acatarse las normas de respeto y no discriminación respecto de todos sus integrantes - mujeres y ninos incluídos" MANRIQUE, Ricardo C. Perez. Nuevas formas familiares - Demografía Y Derecho de Familia. In. DIAS, Maria Berenice e BASTOS, Eliene Ferreira. Família além dos mitos, Ed. Del Rey, Belo Horizonte, 2008, pág. 261/264.

2 TEIXEIRA, Ana Carolina Brochado. Família, Guarda e Autoridade parental. Ed. Renovar, 2005, pág. 12

${ }^{3}$ HIRONAKA, Giselda Maria Fernandes Novaes. A incessante travessia dos tempos e a renovação dos paradigmas: a família, seu status e seu enquadramento na pós-modernidade. In. DIAS, Maria Berenice e BASTOS, Eliene Ferreira. Família além dos mitos. Ed. Del Rey, Belo Horizonte, 2008, pág 52.

4 BITTAR, Eduardo C.B. O Direito na pós-modernidade. Rio de Janeiro. Forense Universitária, 2005, p. 6.
} 
da pós-moderna, famílias que foram se sucedendo, com a mudança dos costumes, com a alteração de valores, com a introdução de novos comportamentos e princípios e até mesmo com o abandono de costumes e tradições.

Maria Berenice Dias e Rodrigo da Cunha Pereira indicam, ainda, fatores que influenciaram as alterações da família contemporânea "sexo, casamento e reprodução sempre foram os elementos estruturadores da família, servindo de paradigma para a sua organização jurídica. No entanto, não mais é necessário ato sexual para a concepção e, ademais, o casamento deixou de ser o único meio de legitimar as relações afetivas. Conseqüentemente, a dissociação desses elementos impõe que se reveja o conceito de família. Mas, ainda assim, não se pode dizer que tenha ela sofrido um processo de desagregação. É irrefutável a premissa de que a família ainda é o que sempre foi e será: a célula básica da sociedade, ponto de partida a possibilitar o desenvolvimento das outras relações sociais". 5

É por isto que a lei não define a família, nem é possível dar-lhe um conceito geral porque o grupo familiar tem distinta amplitude nos diversos aspectos em que é considerado.

Quanto à conceituação da família, explica Marisa Herrera que no direito argentino tanto os tratados internacionais de direitos humanos como a Constituição Argentina, em seu artigo 14, utilizam uma fórmula ampla sobre a família. Não se tenta defini-la, as normas apenas sinalizam que a família deve ser protegida, dado seu caráter de núcleo social e célula básica da sociedade. ${ }^{6}$

De fato, desta ou daquela forma, com estas ou aquelas palavras, o conceito de família atravessa o tempo, sempre tentando clarear e demarcar o seu limite, especialmente para fins de Direito.

Neste contexto, na busca do significado do termo família, como produto cultural, que, ao longo dos tempos, tem-se apresentado de formas distintas, o termo provém do latim "famulia", por derivação de "famulus", i, do osco "famel", designando o

\footnotetext{
${ }^{5}$ DIAS, Maria Berenice. PEREIRA, Rodrigo da Cunha (coord.). Direito de Família e o novo código civil. Belo Horizonte, Del Rey, 2005, prefácio, pág. Vii.

6 "em el derecho argentino, desde la perspectiva constitucional - reitero, mirada suprema y obligada - cabe destacar que, tanto los tratados internacionales de derechos humanos como la Constitución Nacional Argentina em su art. 14 bis, utilizan uma fórmula amplia sobre la família. No se la intenta definir, y consigo circunscribir. Todo lo contrario, estas normativas solo se detienen a senalar que la família debe ser protegida dado su caracter de núcleo social o célula básica de la sociedad.". HERRERA, Marisa. Filiación, adoptión y distintas estructuras familiares em los albores del siglo XXI. In. DIAS, Maria Berenice e BASTOS, Eliene Ferreira. Família além dos mitos. Ed. Del Rey, Belo Horizonte, 2008, pág. 151/200.
} 
conjunto de pessoas submetidas à autoridade do 'pater famílias', pessoa que, na família romana, tinha poderes absolutos sobre as pessoas e coisas a ele submetidos.

E, para compreender tal origem da família, necessário conhecer as etapas de sua evolução nas diferentes civilizações, especialmente na romana, que fortemente influenciou a nossa sociedade.

No direito romano, a família foi comunidade política, religiosa e econômica. Para o seu estudo e melhor contextualização dentro da evolução histórica da sociedade romana, necessária a divisão em períodos, assim recomendados: o direito préclássico - das origens de Roma, que segundo a tradição foi fundada em 754 a.C., até aproximadamente 126 a.C.; o direito clássico - da data do término do direito pré-clássico ao término do reinado de Diocleciano em 305 d.C. -; e o direito pós-clássico - da data do término do direito clássico à morte de Justiniano, em 565d.C..

A família romana, enquanto grupo de pessoas vinculadas pelo parentesco ou pelo casamento poderia ser classificada em cinco grupos: as gens (cujos membros, que se denominavam gentiles, se julgavam descendentes de um antepassado comum, lendário e imemorável, do qual recebiam o nome gentílico, que os unia); a família 'comune iure' (conjunto de pessoas que, sendo agnados, isto é, ligadas pelo parentesco agnatício, que se transmitia apenas pelo homem, estavam sujeitas à 'potesta' de um 'pater familias' comum); a família 'proprio iure' (complexo de pessoas que se encontravam sob a 'potestas' de um 'pater familias'); o conjunto de cognados (aqueles que estavam ligados apenas pelo parentesco sanguíneo) e; a família natural (agrupamento constituído apenas dos cônjuges e de seus filhos independente de o marido e pai, ser ou não, 'pater familias' da mulher e dos descendentes imediatos). Cada uma destas formas familiares teve destaque em determinado período, especialmente, as gens no direito pré-clássico e a família 'proprio iuri’ no final do direito pré-clássico e início do direito clássico e a família natural no direito pós-clássico.

No direito pré-clássico a família romana tinha como acentuada característica o patriarcado, aparecendo a figura do patriarca, 'pater familias', como chefe de família, como senhor e proprietário de todos os demais membros e de todo o patrimônio.

Foi em Roma, o reinado e florescimento do regime da família patriarcal, com as características que influenciaram e influenciam considerável parte do mundo ocidental. A concentração do patrimônio da família fez com que as tarefas dentro do lar fossem divididas, aumentando a importância do homem na família. O patriarcado 
determinava o parentesco, a hereditariedade, a posição das crianças de uma família a partir do tronco paterno. Surge então a noção de pátrio poder.

A família era, a um só tempo, unidade política, religiosa e econômica. $\mathrm{O}$ chefe de família concentrava todas estas funções, simbolizando a soberania doméstica. $\mathrm{O}$ 'pater familias' era um homem protetor do lar, provedor da família, sacerdote e transmissor da herança de seus antepassados, inclusive religiosa. Aparece nítido, assim, o termo família ligado com a idéia de servir a um senhor.

O poder do 'pater familias' - coluna vertebral da família patriarcal - era a um só tempo o de um sacerdote, de um legislador, de um juiz e de um senhorio da vida e das fazendas dos que integravam o culto doméstico, exercido de forma absoluta, sem limites e de duração prolongada. Uma das características da 'potestas' era a vitaliciedade.

Registra José Carlos Moreira Alves que "são absolutos os poderes do 'pater familias' sobre as pessoas e coisas a ele submetidas. É ele o chefe militar da família, seu sacerdote e juiz; tem poder de vida e morte sobre todos os membros da família - pode até expor os filhos, ao nascerem; ou depois, vendê-los, no estrangeiro, como escravos. Todo o patrimônio da família lhe pertence; daí, tudo o que as pessoas, que lhe são submetidas, adquirem passa a pertencer a ele. Somente ingressa na família quem o 'pater familias' quiser, até os filhos de sua esposa ele deverá reconhecê-los como seus. E para que uma pessoa 'alieni iuris' saia de sua família é necessário que o 'pater familias' o consinta, pela emancipação ou pela extinção da 'manus maritalis"

Quando morria o 'pater familias' teoricamente a família se dividia em quantos 'filii familias' que ficavam sem ascendente masculino vivo, a que estivessem sujeitos. Contudo, o jurista italiano Bonfante, com base na estrutura do direito hereditário romano, aponta ser possível que esta divisão não ocorresse, observa que, com a morte do 'pater familias' ocorria apenas a sua substituição por um dos 'filii familias' previamente designado, permanecendo indivisível o agrupamento familiar. ${ }^{8}$

O agrupamento familiar gozava de relativa autonomia em face do Estado, posto que o Estado não interferia nas questões surgidas no seio da família, as quais eram soberanamente decididas pelo 'pater familias', chefe absoluto, que não possui, na linha masculina ascendente vivo a que esteja sujeito.

Neste período, por boa parte, predominou como forma de agrupamento familiar as 'gens', que além de serem unidades religiosas e econômicas, tinham, em

\footnotetext{
${ }^{7}$ ALVES. José Carlos Moreira.Direito Romano. 14ª edição, Ed. Forense, Rio de Janeiro, 2008, pág. 605.

${ }^{8}$ BONFANTE. Corso di Diritto Romano I, Diritto de Famiglia, reimpressão, p. 11 e segs., Milano, 1963.
} 
especial, caráter político, dada sua finalidade de manutenção da ordem e de proteção contra inimigos externos.

O fundamento da família era o matrimônio. Ela não era natural, mas uma criação do Direito. Era como se fosse um pequeno Estado que tinha em sua cabeça um soberano despótico. Sua legislação começava sempre pela teoria do poder. O vínculo estabelecido não era o de sangue, mas aquele produzido pelo parentesco a um antepassado comum ou pelo matrimônio.

No final do período pré-clássico e início do período clássico, predominou a 'familia próprio iure' - complexo de pessoas que estavam sujeitas a 'potestas' do pater familias'-, uma das principais formas de agrupamento familiar a ser estudada no direito de família romano, dada a sua importância na sociedade.

O ingresso na 'familia proprio iure' se dava pela procriação em justas núpcias (criança nascida de justas núpcias no seio da família); pela adoção (ato jurídico pelo qual alguém ingressa como 'filius familias' em família que não é a sua de origem) ou pela legitimação (filhos nascidos de concubinato adquirem a condição de filhos legítimos) que somente foi admitida no direito pós-clássico.

As mulheres ingressavam na família do marido, sujeitando-se à 'manus' - poder marital - ou, se seu marido fosse 'alieni iuris' ao poder de seu 'pater familias'. A 'conventio in manu' podia se dar pela 'confarreatio' (cerimônia religiosa e solene com formalidades bastante complexas); pela 'coemptio' (cerimônia que utilizava os ritos da emancipação, provavelmente celebrava-se uma venda fictícia da mulher ao marido) e, pelo 'usus' (modo de aquisição da 'manus' que se assemelhava ao usucapião. O marido, pelo 'usus' adquiria a 'manus' sobre a mulher se vivessem em comum durante um ano inteiro, porém, a mulher poderia evitar a 'conventio in manu' se se afastasse da casa do marido por três noites consecutivas - 'usurpatio trinoctii).

A mulher ingressava na família do marido 'in loco filiae', ou seja, como se fosse filha do marido, tornando-se, assim, sua parenta agnada. Consequentemente, a mulher se desvinculava de sua família de origem, conquanto dela permanecesse cognada, uma vez que o parentesco consanguíneo não se extinguia com a 'conventio in manu'.

Ao adquirir a 'manus' o marido passava a ter sobre a mulher direito de vida e morte, porém havia necessidade de ouvir o 'tribunal domesticus' do qual participavam os parentes cognados da mulher; direito de vendê-la, mas, segundo os autores romanistas, só nas hipóteses de venda fictícia - 'mancipatio' e não venda efetiva; a mulher podia ser abandonada pelo marido. Os bens da mulher eram integrados ao patrimônio do 
'pater familias' e, se ela fosse 'alieni iuris' levava o dote. A mulher não podia se obrigar civilmente.

Porém, quando o casamento era 'sine manum' o patrimônio da mulher e do marido eram distintos. Havia a integral independência econômica entre os cônjuges. Estes bens eram denominados de bens parafernais e, em geral eram administrados pelo marido.

Registramos, contudo, que a 'manus' independia do casamento. $\mathrm{O}$ divórcio dissolvia o casamento, mas não a 'manus', que tinha meios próprios de extinção.

No direito clássico, contudo, a 'familia próprio iure' observou sua decadência, dada a importância progressiva da família natural, baseada no casamento e no vínculo de sangue, na qual se destaca o parentesco cognatício.

Com o fim da República, houve a adaptação da família às novas condições sociais de Roma. Desaparecem os últimos vestígios da 'gens' e, portanto, a característica de organismo político da família.

É a partir do direito clássico que a família romana, organizada sob a forma patriarcal e hierarquizada, começa a perder este caráter. A autoridade despótica do 'pater famílias', sofre atenuações e o parentesco de sangue obtém certo favor. O norte da economia deixa de ser a família e passa a ser o indivíduo e o culto doméstico é absorvido pela religião do Estado. A família, então, perde seu exclusivismo e adquire feições inteiramente novas, identificando-se em certos pontos, com a família moderna.

Neste período o poder do 'pater famílias' deixou de ser absoluto. Cessou o direito de vida e morte do pai sobre o filho sem motivação; o filho podia pedir proteção contra o 'pater familias' ao Estado; os 'filii familias' passaram a ter direitos de praticar negócios em nome próprio. Houve também a restrição do poder marital, a mulher, quando casava, continuava vinculada ao seu 'pater familias' de origem e, se, 'sui iuris'; seus bens lhe pertenciam, não ingressando no patrimônio da família do marido; passaram a ser admitidas obrigações recíprocas entre marido e mulher; a mãe ligou-se com laços mais estreitos aos filhos, houve a criação do direito sucessório entre mãe e filho e, ainda, deu-se à mãe a guarda de seus filhos quando o pai ou tutor tinha má-conduta.

O casamento, segundo Bonfante, era uma situação de fato que se iniciava sem qualquer formalidade, com o simples acordo de vontade do homem e da mulher, e que perdurava enquanto existisse a intenção dos cônjuges em permanecerem casados. Não bastava o consentimento inicial, era necessário o consentimento continuado. Assim, para o casamento de rigor a presença de dois requisitos, a 'afecctio maritalis' (elemento subjetivo) 
e a convivência (elemento objetivo). Para Bonfante o casamento romano "é a convivência do homem e da mulher com a intenção de serem marido e mulher"'

No direito justinianeu ou pós-clássico, a família continua em evolução, com o aumento das restrições da 'potestas' do 'pater familias'. Registra José Carlos Moreira Alves: “A princípio, os poderes do 'pater familias' enfeixados na 'patria potestas' são absolutos: o poder 'pater familias' pode ser comparado a um déspota. A pouco e pouco, porém, e essa tendência se avoluma decididamente a partir do início do período pós-clássico - os poderes constitutivos da 'patria potestas' se vão abrandando, até que, no direito justinianeu - mudado o ambiente social, alternadas fundamentalmente as funções e a estrutura da família romana, e sobrepujado o parentesco agnatício pelo cognatício - a 'patria potestas' se aproxima do conceito moderno de pátrio poder (poder educativo e levemente corretivo) embora conserve o que a afasta deste, a vitaliciedade e a titularidade, não pelo pai natural, mas pelo ascendente masculino mais remoto" 10

Neste período, os pais que matavam os filhos eram punidos - penas do parricidium. Os bens adquiridos pelos 'filii familias' no exercício de cargo na Corte, de advocacia e, por fim de cargo público ou eclesiástico, passaram a integrar o seu patrimônio - 'peculium quase castrense'; desapareceu a incapacidade relativa das mulheres, as filhas poderiam se obrigar por contrato. As mulheres então, passaram a desfrutar de completa autonomia, participando da vida social e política.

Como dito, cresceu nesta época a importância da família natural como forma de agrupamento familiar. Tal agrupamento era constituído apenas dos cônjuges e de seus filhos, independentemente de o marido ser ou não o 'pater familias'. Ao se estudar a família natural, privilegia-se a análise das relações pessoais e patrimoniais em detrimento dos efeitos da 'manus' e da 'potestas'.

A família natural tinha por base o casamento. Imposta a monogamia, surgiu uma nova ordem sexual na sociedade, que antes era permissiva quanto à infidelidade do chefe de família, que poderia possuir diversas esposas, diversos os benefícios trazidos ao grupo social.

Na família ampla, em que o lar se compunha de um grande número de pessoas, considerando-se a prole numerosa, os agregados, os demais parentes, todos convivendo no mesmo ambiente, inviabilizava-se a consolidação de maior intimidade ou

\footnotetext{
${ }^{9}$ BONFANTE. Instituzione di Diritto Romano, $1^{\text {a }}$ Ed., $§ 58$, p. 137 - ristampa della X edizione, Torino, 1946, $\S 58$, p. 180)

${ }^{10}$ ALVES. José Carlos Moreira. Direito Romano. 14ª edição, Ed. Forense, Rio de Janeiro, 2008, pág. 621.
} 
amizade entre os membros do grupo familiar natural, tornando os relacionamentos muito sérios, rigorosos e severos, sem grande manifestação de afetividade ou cumplicidade. Sem espaço também para as discussões e exposição de pontos de vista, as regras seculares se mantinham com eficiência, e a transmissão de valores como tradição e obediência se processava sem tumultos, de uma geração para outra, de cima para baixo. ${ }^{11}$

No direito pós-clássico ocorreram profundas mudanças no instituto do matrimônio por influência do Cristianismo. O matrimônio passou a fundar-se na vontade inicial dos nubentes, da qual decorria o vínculo conjugal, que, ao contrário do que ocorria no direito clássico, independia da vontade contínua dos cônjuges de permanecerem casados. O vínculo só se dissolvia com a morte ou com o divórcio.

Até Justiniano o divórcio era livre, pelo consentimento comum, era possível também o divórcio unilateral. Na época dos Imperadores Cristãos, por influência da Igreja, chegaram a combater o divórcio, sem, no entanto, proibi-lo.

Com as invasões bárbaras e a decadência do Império Romano do Ocidente, em 476 d.C, a família recebeu influência germânica, o que definitivamente representou a redução do grupo familiar aos pais e filhos, como atualmente a reconhecemos.

A partir do século $\mathrm{V}$, com o decorrente desaparecimento de uma ordem estável que se manteve durante séculos, houve um deslocamento do poder de Roma para as mãos do chefe da Igreja Católica que desenvolveu o Direito Canônico estruturado num conjunto normativo dualista (laico e religioso). Como consequência, na Idade Média, o Direito, confundido com justiça, era ditado pela Religião, que possuindo autoridade e poder, se dizia intérprete de Deus na terra.

Por certo, foi por influência do Cristianismo que a família passou a ter um caráter sacramental. Embora se possa pensar que o casamento para o Direito romano tinha mais sentido religioso, sua concepção era mais de relação jurídica que de uma celebração propriamente. $\mathrm{Na}$ verdade, foi o cristianismo que elevou o casamento à dignidade de sacramento: "Homem e mulher selam a sua união sob as bênçãos do céu, transformando-se numa só entidade física e espiritual e de maneira indissolúvel". ${ }^{12}$

$\mathrm{Na}$ Idade Média o casamento foi fortemente influenciado pelo Direito Canônico que regeu exclusivamente as relações de família. Do século $\mathrm{X}$ ao século $\mathrm{XV}$, o

${ }^{11}$ PEREIRA, Rodrigo da Cunha. Direito de Família: uma abordagem psicanalítica. Belo Horizonte, Del Rey, 1997, pág. 61.

${ }^{12}$ PEREIRA, Rodrigo da Cunha. Direito de Família: uma abordagem psicanalítica. Belo Horizonte, Del Rey, 1997, pág. 35. 
casamento religioso é o único conhecido. Foram introduzidas alterações jurídicas na estrutura familiar, como a indissolubilidade do vínculo matrimonial e os impedimentos para o casamento, em razão da incapacidade dos nubentes - idade, casamento anterior, infertilidade, diferença de religião, falta de consentimento, parentesco.

Para o Direito Canônico, o casamento se realizava apenas com o consenso das partes que declaravam sua vontade, geralmente em público, e na presença do sacerdote e, então se aperfeiçoava com a cópula carnal.

A Igreja, como não admitia a dissolução do vínculo matrimonial, não permitia o divórcio, no entanto, em casos específicos, como adultério ou tentativa de homicídio, permitia a separação de corpos, mediante autorização do bispo.

No fim da Idade Média, marcada pela queda de Constantinopla tomada pelos turco-otomanos em 1453, com o fortalecimento da autoridade do rei, surgiram conflitos entre os tribunais civis e religiosos, especialmente quanto aos aspectos patrimoniais do direito de família.

Os países católicos recebiam forte influencia da Igreja, assim, sua legislação seguia os moldes da lei canônica. O casamento tinha caráter sacramental e era de competência exclusiva da Igreja. Já os países protestantes acreditavam que a competência em matéria de família deveria ser exclusivamente do Estado, posto tratar de ato simples da vida civil.

Mas, por interesses sociais e políticos da sociedade - o casamento era um ato que importava à comunidade, que não desejava que os filhos casassem sem a autorização dos pais - assim como, em razão da existência de minorias não católicas, passou-se a admitir nos países católicos o casamento civil, ao lado do casamento religioso

E assim, pouco a pouco, o poder civil passou a legislar sobre o direito de família, absorvendo a autoridade eclesiástica. Distinguiu-se, então, os aspectos civis e religiosos do casamento, vinculados respectivamente ao Estado e à autoridade eclesiástica.

A partir do século XVIII, com o surgimento do industrialismo, a produção se desenvolve fora da unidade familiar e a propriedade imobiliária cede lugar aos valores mobiliários. A família perde o traço que a caracterizava como núcleo de produção, transformando-se em organização de consumo. Perdendo sua força econômica, circunscreve-se ao âmbito biológico e espiritual onde se desenvolvem os vínculos da solidariedade e assistência recíprocos.

Na Idade Moderna a família nuclear ou conjugal, composta pelos pais e seus filhos, adquire relevância, e a importância por ela alcançada é consequência da 
ideologia do indivíduo privado, isolado e auto-sufuciente. Nesta época, difunde-se a idéia de valorar os direitos da intimidade e da privacidade, permitindo uma mudança do enfoque que da família se tinha até então, sobressai, então, o vínculo de amor e solidariedade entre seus integrantes.

Mas, ainda trata-se de um tempo de divisão do trabalho na família pelo sexo. A mulher organizava o lar, cuidava dos filhos, enquanto o marido trabalhava para prover o sustento. Tal divisão acarretava na dependência do casal. Havia uma relação de autoridade: poder externo masculino e poder interno feminino.

Na Idade Contemporânea, após a Revolução Francesa e já sob a influência da Revolução Industrial, a família continuou sua evolução, mas, sempre dentro dos princípios do patriarcado.

A concepção geral que perdurou por longo tempo sobre a família era da estrutura tradicional composta pelo pai, mãe e seus filhos, exatamente nesta ordem. A família possuía uma estrutura patriarcal, na qual um pai servia, em princípio, para cuidar dos interesses patrimoniais da família. Servia também para dar continuidade ao seu próprio nome e à continuidade genética de seus ascendentes.

Como se pode observar, a família possuía interesses predominantemente patrimoniais, já que refletia, especialmente nas últimas décadas, o Estado Liberal, do homem livre e proprietário do início do século $\mathrm{XX}$, bases em que foram assentadas a legislação sobre a família no Brasil (Código Civil de 1916).

O modelo conceituado como família legítima era aquele originado de primeiras núpcias. Entretanto, as transformações ocorridas na sociedade, ao longo dos anos, especialmente com a passagem do Estado Liberal para o Estado Social, nos mostram uma outra realidade, na qual as novas formas familiares são um fato social.

O homem entendeu que era possível escolher seus próprios caminhos e deixou de ser mero objeto para tornar-se sujeito. Assim, as pessoas, antes à margem da concepção formal de família, passaram a reivindicar a sua inserção e o reconhecimento pela sociedade.

No momento em que o formato hierárquico da família cedeu à sua democratização, decorrente da transformação da própria sociedade, as relações entre os seus entes são de igualdade e de respeito mútuo, e o seu traço fundamental é a lealdade.

Neste passo, o conceito de família, seguindo a evolução da sociedade, foi transformado e atualmente a família identifica-se pela comunhão de vidas, de amor e de afeto no plano da igualdade, da liberdade, da solidariedade e da responsabilidade recíproca 
entre os seus membros. Diríamos até que da estrutura piramidal, a família passou para a estrutura circular.

Para Rodrigo da Cunha Pereira, "o patriarcado, que serviu durante séculos como referência, está posto em questão neste nosso tempo. O pai, na realidade, está perdendo o lugar de garantidor e provedor. A lei jurídica já estabeleceu a igualdade entre homem e mulher para o governo e sustento da família." "O avanço do Direito em relação a estes conceitos tem-se dado mais pela pressão da sociedade e da cultura, sem que exista estudo sistemático interdisciplinar daqueles que trabalham no campo estritamente jurídico." 13

Nesta evolução, de uma sociedade total e única para um estágio em que as relações familiares têm sede no amor, na compreensão, na igualdade, dela dizendo-se uma comunidade de afeto e entreajuda assumiu vários matizes. A família tornou-se plural, na sua origem ou formação.

\section{A FAMILIA NO ORDENAMENTO JURÍDICO BRASILEIRO}

Referidas mudanças foram percebidas pelo ordenamento jurídico que, também, ao longo do tempo, foi evoluindo.

As transformações vividas pela sociedade foram percebidas, especialmente pelo direito de família, que sofreu grandes transformações nos últimos tempos, principalmente quanto à estrutura familiar.

O século XIX, contudo, especialmente na sua segunda metade, testemunhou uma significativa mudança no perfil da família brasileira que - graças a uma série de fatores importantes como, por exemplo, a urbanização das cidades, a chegada da luz elétrica, a introdução de modos e costumes europeus trazidos pela corte portuguesa, a mesclagem de culturas por força do aumento do ciclo imigratório - adquiriu uma feição mais voltada à formação de família a partir da própria e pessoal escolha do par conjugal, o que refletiu na reformulação de papéis do homem e da mulher no cenário doméstico, bem como no mercado de trabalho. Outra passou a ser a dinâmica familiar, ainda que - é necessário que se registre - o jugo da mulher ao homem ainda permanecesse, de certa

\footnotetext{
${ }^{13}$ PEREIRA, Rodrigo da Cunha. Direito de Família: uma abordagem psicanalítica. Belo Horizonte, Del Rey,
} 1997, pág. 13. 
forma, dentro do lar, mesmo que ela já houvesse conquistado o direito ao trabalho, especialmente as mulheres de classe média, da chamada burguesia. ${ }^{14}$

A estrutura patriarcal que por muito tempo se manteve intacta foi se transformando. Houve uma ruptura estrutural na qual o lugar do homem, enquanto provedor e pai, foi questionada a partir de sua suposta superioridade. O pai representava a lei dentro do lar. Questionou-se, então, o lugar demarcado e as funções atribuídas a cada um dentro da estrutura familiar, enquanto marido e mulher, pai e mãe, e filhos. Anunciouse então a igualdade dos gêneros. Novas estruturas familiares surgiram. Novos papéis foram atribuídos aos integrantes. E, então, a partir de todas as mudanças observamos a modificação incessante da legislação, visando regulamentar os institutos.

As Constituições brasileiras de 1824 e 1891 são marcadamente liberais e individualistas, não tutelaram, pois, as relações familiares.

A primeira Constituição do Brasil, outorgada em 1824 pelo Imperador D. Pedro I, não fez nenhuma referência à família ou ao casamento. Apenas, em seu Capítulo III tratou da família imperial.

$\mathrm{Na}$ Constituição Federal de 1891 havia um único dispositivo que reconhecia apenas o casamento civil como forma de constituição de família, dizia o artigo 72, §4: “A República só reconhece o casamento civil, cuja celebração será gratuita”. Este artigo ficou inserido nesta Constituição em razão da separação Igreja/Estado. A partir do regime republicano, o catolicismo deixou de ser a religião oficial e assim tornou-se necessário mencionar o casamento civil como vínculo constituinte da família brasileira.

O casamento civil foi regulamentado pelo Decreto 181 de 1890, de autoria de Rui Barbosa. A partir de então deixou a legislação eclesiástica de regulamentar o casamento. Para o Estado, passou a ser considerado válido o casamento realizado perante as autoridades civis. Admitiu-se também a separação de corpos por justa causa ou mútuo consentimento, foi, contudo mantida a indissolubilidade do vínculo.

O Código Civil de 1916, na mesma esteira, condicionou a legitimidade da família ao casamento civil. A família tratada pelo Código era matrimonializada, patriarcal, hierarquizada, patrimonializada e heterossexual. O Código não permitia sequer a dissolução do casamento. Assim, evitava-se que o patrimônio adquirido ao longo do casamento se dissipasse. A posição adotada pelo legislador de 1916 era evidentemente

\footnotetext{
${ }^{14}$ HIRONAKA, Giselda Maria Fernandes Novaes. A incessante travessia dos tempos e a renovação dos paradigmas: a família, seu status e seu enquadramento na pós-modernidade. In. DIAS, Maria Berenice e BASTOS, Eliene Ferreira. Família além dos mitos. Ed. Del Rey, Belo Horizonte, 2008, pág. 62.
} 
discriminatória. Não só não eram reconhecidas outras formas familiares, como havia distinção entre os filhos havidos ou não do casamento. O homem era chefe de família em oposição à mulher, que o direito incluía no rol dos relativamente incapazes.

Naquele modelo codificado de família, a sociedade era basicamente rural e a família funcionava como unidade de produção. Registre-se, o número de integrantes era considerável, eis que reunia além dos filhos, agregados e outros parentes, o que significava força de trabalho e maiores condições de sobrevivência para o grupo.

O homem era o chefe da família, exercia tanto papel de pai como de marido. A ele competia a direção exclusiva da família, administrava os bens comuns e tinha o direito de fixar o domicílio do casal. Mulher e filhos ocupavam posição de inferioridade na comunidade familiar. A primeira desempenhava o papel de esposa e mãe, enquanto que os demais deviam ater-se ao respeito ao pai. A divisão dos papéis se dava em função do sexo e da idade, sendo que ao homem incumbia também o dever de zelar pela unidade familiar. Sua autoridade e seu poder tinham origem de cunho econômico.

Aliás, verificada a História, o lugar da mulher no Direito, sempre foi marcada pela ausência, dado que, sua figura sempre esteve subordinada à do marido, sem qualquer voz ativa.

O lugar de autoridade, da representação da lei sempre foi do homem. Todos os registros indicam a predominância masculina no mundo. Até mesmo quando uma mulher, quando ascende ao poder, quando exerce uma função de autoridade, se apresenta com um discurso masculino. É o que Freud nomeia de discurso "fálico". Aquele que advém de uma força que, supostamente, é masculina. ${ }^{15}$

De fato, na sociedade conjugal, a direção sempre foi exercida pelo homem. Todas as decisões objetivamente mais importantes couberam a ele. Na representação da autoridade em relação aos filhos, também, foi ele quem ocupou este lugar. Desta forma, garantia-se a manutenção da estrutura familiar baseada no matrimônio, também como modelo para legitimidade dos filhos, pautado na proibição do reconhecimento dos extramatrimoniais e na atuação da presunção pater is est.

E, acrescenta Giselda Maria Fernandes Novaes Hironaka, "não apenas isso, mas a condição matrimonializada foi sempre eternizada, com chance zero de desorganização ou desfazimento, especialmente se em favor da libertação da mulher, uma vez que a sua projeção e atuação no meio familiar estava muito mais voltada à concepção,

${ }^{15}$ PEREIRA, Rodrigo da Cunha. Direito de Família: uma abordagem psicanalítica. Belo Horizonte, Del Rey, 1997. 
geração e criação de filhos do que propriamente ao prazer que lhe pudesse ser proporcionado pela relação sexual e afetiva com o seu partícipe de jornadas. A proclamação da pureza das mulheres, a condenação ao adultério, a proibição do aborto e a recriminação às práticas contraceptivas concorrem no sentido de a elas não ser permitido o que aos homens era, ainda que sob os pudores silenciosos da falsa moral novecentista, como o desfrute de prazeres efêmeros, por exemplo. A visibilidade do adultério masculino contava, por isso mesmo, com a complacência social e até mesmo religiosa em certos casos, minimizando, em favor dos homens uma severidade e uma rigidez que sempre estiveram presentes na trajetória de condutas femininas." 16

Contudo, registre-se, o Código Civil de 1916, sob grande influência napoleônica, substituiu leis esparsas de origem portuguesa, que, na época significou grande avanço para as mulheres a permissão de assumir, com o casamento, os apelidos do marido; a condição de consorte e companheira e, ainda, o direito de dispor livremente do produto de seu trabalho.

A Revolução Francesa provocou modificações profundas entre homem e mulher a partir da filosofia das Luzes, que visando à felicidade e a valorização do amor, deu importante passo rumo a igualdade de direitos, não obstante não tenha consolidado juridicamente a igualdade entre homem e mulher.

Foi nessa época que as mulheres começaram a reivindicar acesso à cena pública. Com a Revolução Industrial, a mulher começa a deixar a vida doméstica para ajudar na produção em série, sendo assim, inserida no mercado de trabalho, provavelmente porque, seria mão-de-obra barata.

No Brasil, a primeira conquista feminista se deu com a Constituição Federal de 1934, quando foi conferido às mulheres o direito ao voto.

Mas, somente em 1962 surgiu de forma bastante expressiva o Estatuto da Mulher Casada (Lei n 4.121/62), que equiparou os cônjuges, devolvendo à mulher casada sua capacidade plena, assegurando-lhe o direito de propriedade de forma exclusiva e os bens adquiridos com o fruto de seu trabalho.

De fato, foi o Estatuto da mulher casada um importante avanço na medida em que retirou a qualidade de relativamente incapaz da mulher casada, porém não retirou a hierarquia existente dentro da sociedade conjugal, ao manter o homem na chefia,

\footnotetext{
${ }^{16}$ HIRONAKA, Giselda Maria Fernandes Novaes. A incessante travessia dos tempos e a renovação dos paradigmas: a família, seu status e seu enquadramento na pós-modernidade. In. DIAS, Maria Berenice e BASTOS, Eliene Ferreira. Família além dos mitos. Ed. Del Rey, Belo Horizonte, 2008, pág. 58.
} 
na qualidade de representante legal da família, administrador dos bens, responsável pela fixação do domicílio e manutenção da família.

Até o ano de 1977, não era possível o divórcio. A Lei 6.515/77 permitiu a dissolução da sociedade conjugal, mas ainda, apresentava longos prazos, na tentativa de manter a família unida.

Lembra Giselda Maria Fernandes Novaes Hironaka que "ainda assim, não foi exatamente de um dia para o outro que o divórcio, como percurso para o reencontro de destinos mais promissores, instalou-se no mundo contemporâneo. As pressões de toda sorte, morais, religiosas, éticas e culturais, empataram durante grande número de décadas, e até hoje, a aceitação plena do rompimento da matrimonialização das relações conjugais. Às mulheres divorciadas imputou-se o status da indignidade e aos seus filhos, a pecha de filhos sem pai." 17

Contudo, o divórcio, possibilitou a dissolução de vínculos até então indissolúveis, que, por obrigatoriedade de realização contínua, se mantinham a qualquer custo. E isto, como nos relata a história, não foi motivo para a decadência do instituto da família, que, continua como base da sociedade e lócus privilegiado de convivência e do amor. Porém, acabada a indestrutividade do vínculo, permitiu-se aos integrantes do grupo, que não mais se realizavam naquele casamento, novas aspirações e novos valores, Viabilizou-se, então, a liberdade de expressão e a revalorização do sentimento, bem como a autorização para cada membro buscar a sua própria felicidade e bem-estar, valorizando mais o indivíduo.

Só as Constituições do Estado-social brasileiro (1934 e 1988) dedicaram um capítulo inteiro à família, sendo que, em 1934, aparece pela primeira vez a referência expressa à proteção especial do Estado, repetida nas Constituições subsequentes.

A partir de então, que, refletindo as modificações sociais, as Constituições passaram a dedicar capítulos à família e a tratá-la separadamente, dando-lhe maior importância. As Constituições de 1937, 1946, 1967 e 1969 (Emenda n. 1/69), seguindo a mesma linha de pensamento do constituinte de 1934, traziam em seu texto um sentido único de que o casamento indissolúvel era a única forma de se constituir uma família.

\footnotetext{
${ }^{17}$ HIRONAKA, Giselda Maria Fernandes Novaes. A incessante travessia dos tempos e a renovação dos paradigmas: a família, seu status e seu enquadramento na pós-modernidade. In. DIAS, Maria Berenice e BASTOS, Eliene Ferreira. Família além dos mitos. Ed. Del Rey, Belo Horizonte, 2008, pág. 59.
} 
A Declaração Universal dos Direitos do Homem, em seu art. XVI, 3, já estabelecia: "A família é o núcleo natural e fundamental da sociedade e tem direito à proteção da sociedade e do Estado".

O que a nova ordem mundial trouxe foi um redirecionamento de papéis, na estruturação da família, em que se questionou e - até hoje - redimensiona-se o lugar do homem e da mulher.

Porém somente a Constituição Federal de 1988 refletiu as profundas alterações sociais, trazendo novos paradigmas e valores para o direito de família. A Constituição de 1988 proclama que a família é a base da sociedade e tem direito à proteção da sociedade e do Estado.

Maria Berenice Dias e Rodrigo da Cunha Pereira fazem interessante reflexão quanto aos fatos sociais das últimas décadas, que refletiram na transformação da família e, consequentemente no ordenamento jurídico: “A partir da segunda metade do século XX, está-se vivendo um importante processo de transformação, determinado - entre outros fatores - pela quebra da ideologia patriarcal, impulsionada pela revolução feminista. À evolução do conhecimento científico, somaram-se o fenômeno da globalização, o declínio do patriarcalismo e a redivisão sexual do trabalho, a ensejar uma profunda mudança na própria família. A travessia para o novo milênio transporta valores totalmente diferentes, mas traz como valor maior uma conquista: a família não é mais essencialmente um núcleo econômico e de reprodução, onde esteve instalada a suposta superioridade masculina. Passou a ser - muito mais do que isso - o espaço para o desenvolvimento do companheirismo, do amor e, acima de tudo, o núcleo formador da pessoa e elemento fundante do próprio sujeito. ${ }^{18}$

A mudança dos paradigmas constitucionais, para Silvana Maria Carbonera, reflete as alterações sociais, em especial da admissão das novas estruturas familiares: “a Constituição Federal de 1988, nitidamente relacionada a um Estado do Bem-Estar Social, demonstrou acentuada preocupação com o social, o que resultou na maior intervenção nas relações sociais. Com o reconhecimento da multiplicidade de famílias pela Carta Constitucional, houve o aumento da tutela, assim como da esfera de liberdade de escolha dos sujeitos. Isto redundou no fato de que, embora continuem existindo famílias nos moldes patriarcais, a recepção de outras formas abriu espaço para

\footnotetext{
${ }^{18}$ DIAS, Maria Berenice. PEREIRA, Rodrigo da Cunha (coord.). Direito de Família e o novo Código Civil. Belo Horizonte, Del Rey, 2005, prefácio, pág. viii.
} 
famílias fundadas no afeto e no desejo de estar junto, formando uma comunhão de vida e fazendo com que seja seu elemento central". ${ }^{19}$

Contempla a Constituição de 1988 uma série de reformas pelas quais passou a instituição familiar, no curso do século XX, evolução notada, especialmente se adotado como marco a edição do Código de 1916, que limitava o grupo familiar ao originado do casamento, impedindo sua dissolução, distinguindo seus membros e, discriminando as pessoas unidas sem casamento e os filhos nascidos fora de relações matrimoniais.

Os filhos extramatrimoniais sempre foram uma realidade. Contudo, por razões moralistas, os filhos nascidos fora de relações matrimoniais recebiam o selo de ilegítimos, em contraposição aos legítimos. Deste modo, acreditava o Estado controlar as relações sexuais estabelecendo que estas só poderiam existir dentro do casamento. No entanto, apesar de todos os esforços e tentativas, a legislação não mudou o comportamento social. Teve, pois, que se adequar à sociedade.

O progresso se deu em etapas, com a edição de leis esparsas, especialmente a partir da década de 60 , modificando a condição da mulher casada (Lei $\mathrm{n}^{\circ}$ 4.121/62) e instituindo o divórcio (Emenda Constitucional n. 9/77 e Lei no 6.515/77), pondo fim à indissolubilidade do vínculo matrimonial, o que possibilitou a regularização da situação jurídica dos descasados, cujas subsequentes uniões concubinárias eram consideradas à margem do ordenamento.

Importante destacar que até o advento da Constituição Federal de 1988, a legislação brasileira, como a maioria das legislações dos Estados ocidentais, sempre considerou que a família só se constituía pelo casamento, não obstante, a existência de outras formas de família, que não recebiam a proteção do Estado.

Tanto que Orlando Gomes ${ }^{20}$ citando Mazeaud, Mazeaud dizia que: "somente o grupo oriundo do casamento deve ser denominado família, por ser o único que apresenta os caracteres de moralidade e estabilidade necessários ao preenchimento de sua função social”.

Para o Direito brasileiro, a definição de casamento, inicialmente muito misturada com o conceito religioso, mudou tanto quanto variaram os costumes. A noção de matrimônio não é imutável. Com a mudança dos costumes, notável a evolução do instituto.

${ }^{19}$ CARBONERA, Silvana Maria. O papel Jurídico do Afeto nas Relações de Família. In: FACHIN, Luiz Edson. (coord.). Repensando Fundamentos do Direito Civil Brasileiro Contemporâneo. Rio de Janeiro: Renovar, 1998, pág. 294.

${ }^{20}$ GOMES, Orlando. Direito de Família, 14a ed., Forense, Rio de Janeiro, 2002, p. 31. 
O que antes era determinante para a constituição da família no Brasil já foi alterado pela Constituição de 1988, ou seja, no atual ordenamento jurídico a família não se constitui apenas pelo casamento. Há também outras formas de família (art. 226).

Observa Marisa Herrera ${ }^{21}$, que na atualidade, a luz da doutrina internacional dos direitos humanos que predomina no mundo jurídico, a família tradicional não é o único modelo familiar válido dentro do qual se desenvolvem as pessoas ao longo de suas vidas. Diz a autora que a família fundada no matrimônio entre pessoas de diferente sexo - homem e mulher - cujo elemento fundante consiste na procriação ou continuação da espécie, compartilha o cenário com outras configurações familiares, porque a realidade social mudou - e em boa hora - de maneira profunda, deixando arcaica e um tanto hipócrita aquela visão pela qual a família é só aquela derivada da união conjugal.

A sociedade contemporânea observou o declínio da família nuclear, tradicional, de natureza patriarcal típica que existiu até meados do século XX como forma exclusiva de constituição familiar. Verifica-se um aumento no número de divórcios e das uniões estáveis. O modelo hierárquico, predominante até então, cede ao modelo associativo, de nítido corte igualitário, no qual não mais se constata a indiscutida supremacia do marido-pai, a atividade puramente doméstica da esposa-mãe, e tampouco uma absoluta submissão dos filhos, que passam a ter participação na tomada das decisões familiares.

O homem deixa de ser o provedor exclusivo do lar com o ingresso da mulher na vida profissional e intelectual. Como resultado, desaparecem as posições prédefinidas dentro da família nuclear que experimenta uma justaposição das funções, que agora são dividas, permitindo uma maior participação masculina na esfera doméstica. $\mathrm{O}$ maior contato com os filhos permite o desenvolvimento de relações mais afetuosas e íntimas, estreitando os laços familiares.

Nesta evolução, de uma sociedade total e única para um estágio em que as relações familiares têm sede no amor, na compreensão, na igualdade, dela dizendo-se uma 'comunidade de afeto e entreajuda', assumiu variadas matizes.

21 "Em la actualidad, a la luz de la doctrina internacional de los derechos humanos que impera em el mundo jurídico, la família tradicional o nuclear no es el único modelo familiar válido dentro del cual se desarrollan las personas a lo largos de sus vidas. Em otras palabras, la família fundada em el matrimonio entre personas de diferente sexo - hombre y mujer - cuya elemento fundante consiste em la procreación o "propagación de la especie", comparte el escenario com otras configuraciones familiares. !Por qué! La realidad social há cambiado - y em buena ora - de manera profunda, quedando arcaica y um tanto hipócrita, aquella visión por la cual "la" família es solo la derivada de la unión conyugal.HERRERA, Marisa. Filiación, adoptión y distintas estructuras familiares em los albores del siglo XXI. In. DIAS, Maria Berenice e BASTOS, Eliene Ferreira. Família além dos mitos. Ed. Del Rey, Belo Horizonte, 2008, pág. 151. 
Neste contexto, Guilherme Calmon Nogueira da Gama, afirma: "A civilização humana vivencia uma completa reformulação do conceito de família no mundo contemporâneo, no contexto do mundo globalizado. Em todos os cantos do planeta, o modelo tradicional de família vem perdendo terreno para o surgimento de uma nova família, que é essencial para a própria existência da sociedade e do Estado, mas funcionalizada em seus partícipes, uma família que continua sendo imprescindível como célula básica da sociedade, fundamental para a sobrevivência desta e do Estado, mas que se funda em valores e princípios diversos daqueles outrora alicerçados da família tradicional." 22

De fato, a Constituição Federal de 1988 alargou o conceito de família, passou a proteger de forma igualitária todos os seus membros, sejam como partícipes da união, seja como descendentes. Seus pontos essenciais estão nos artigos 226 e 227.

A idéia de família para o Direito brasileiro por muito tempo foi a daquela constituída de pais e filhos unidos a partir de um casamento regulamentado pelo Estado. Com a Constituição de 1988 esse conceito ampliou-se, uma vez reconhecida pelo Estado "como entidade familiar a comunidade formada por qualquer dos pais e seus descendentes", (art. 226). Tal fato significou importante evolução no conceito de família, que, até então, só era reconhecida enquanto entidade constituída pelo casamento. A ampliação do conceito refletiu a própria realidade social.

Conquanto alerte Rodrigo da Cunha Pereira "o casamento, quer nós queiramos ou não, foi e continuará sendo uma forma paradigmática de constituição de família, tanto que todas as regras e toda a regulamentação sobre a união estável têm como paradigma, como referência o casamento". ${ }^{23}$

Enfim, a Constituição Federal de 1988 assumiu novos paradigmas no que concerne à família e seus membros. O Estado passou a proteger as entidades familiares constituídas pela união estável e pelas comunidades formadas por pais e filhos, assim designadas famílias monoparentais.

A proteção estatal, portanto, alcança qualquer entidade familiar, sem restrições.

\footnotetext{
${ }^{22}$ GAMA, Guilherme Calmon Nogueira. Das relações de parentesco. In. Direito de Família e o Novo Código Civil (coord. Rodrigo da Cunha Pereira e Maria Berenice Dias, Ed. Del Rey, belo Horizonte, 2001, pág. $82 / 83$.

${ }^{23}$ PEREIRA. Rodrigo da Cunha. Casamento, união estável, namoro e uniões homoafetivas. In. DIAS, Maria Berenice e BASTOS, Eliene Ferreira. Família além dos mitos. Ed. Del Rey, Belo Horizonte, 2008, pág. 276.
} 
Para Paulo Luiz Netto Lôbo o artigo 226 da Constituição Federal traz os tipos de entidade familiar de forma meramente exemplificativa, por serem os mais comuns, sendo os demais implícitos. Para o professor o conceito é indeterminado e, para a sua concretização depende da adaptabilidade ao tipo. São entidades familiares as que preenchem os requisitos de afetividade, estabilidade e ostensibilidade, submetendo-se, cada uma a um estatuto jurídico próprio, em virtude dos requisitos de constituição e efeitos específicos $^{24}$.

Nasce uma nova família que se funda em valores e princípios diversos dos tradicionais da família patriarcal, matrimonializada e patrimonializada. Rompe-se com o modelo da família hierarquizada fundada exclusivamente no casamento, e, assim, permite-se, o desenvolvimento de relações mais afetivas dentro do núcleo familiar, possibilitando, consequentemente, ser a família, instrumento de realização de seus integrantes.

A nova ordem constitucional trouxe significativas alterações para o Direito de Família, dentre as quais: foi facilitada a dissolução do casamento pelo divórcio direto após dois anos de separação de fato ou pela conversão da separação judicial em divórcio após um ano. Foi reconhecida a igualdade de direitos e deveres do homem e da mulher na sociedade conjugal e, por fim, a igualdade dos filhos, havidos ou não do casamento, ou por adoção, garantindo-lhes os mesmos direitos e qualificações sendo vedada qualquer discriminação decorrente de sua origem.

Vemos que a Constituição Federal de 1988 absorveu toda essa transformação da sociedade e adotou uma nova ordem de valores, privilegiando a dignidade da pessoa humana, realizando verdadeira revolução no Direito de Família, a partir de três eixos básicos, que, para Maria Berenice Dias e Rodrigo da Cunha Pereira, são: “o artigo 226 afirma que a entidade familiar é plural e não mais singular, tendo várias formas de constituição, com o que o Constituinte voltou o seu olhar para a realidade dos arranjos que mostram as várias possibilidades de representação social da família. $\mathrm{O}$ segundo eixo transformador encontra-se no $\$ 6^{\circ}$ do artigo 227. É a alteração do sistema de filiação, de sorte a proibir designações discriminatórias decorrentes do fato de ter a concepção ocorrido dentro ou fora do casamento. Em outras palavras, filho é filho. Porém, enquanto houver desejo sobre a face da terra, crianças fora do casamento continuarão nascendo, mas discriminá-las está definitivamente proibido. A terceira grande revolução

24 LOBO, Paulo Luiz Netto. Entidades familiares constitucionalizadas: para além dos numerus clausus. Revista Brasileira de Direito de Família, Porto Alegre, v. 03, n. 12, p. 40-55, jan.-mar. 2002) 
reside nos artigos $5^{\circ}$, inciso I e $226, \S 5^{\circ}$. Ao consagrar o princípio da igualdade entre homens e mulheres, derrogou mais de uma centena de artigos do atual Código Civil, que data de 1916. No entanto, imperioso ressaltar uma condição: o discurso da igualdade, para ser socialmente eficaz, deve atentar à necessidade do reconhecimento da diferença". ${ }^{25}$

A valorização da pessoa na família é coerente com as linhas gerais da Constituição Federal, uma vez que o artigo $1^{\circ}$, inciso III, consagra como fundamento da República Federativa do Brasil a dignidade da pessoa humana. Deste modo, a proteção à pessoa deve ser princípio orientador no seu tratamento em todas as esferas. A proteção aos componentes da família não constitui exceção à regra, o que conduz à sua priorização em relação ao grupo.

Os artigos 226 e 227 da Constituição Federal de 1988 trazem os pontos essenciais da mudança de paradigma adotada pelo constituinte, assim sintetizados:,1) proteção à família constituída pelo casamento civil, pelo casamento religioso com efeitos civis, pela união estável entre o homem e a mulher e pela comunidade formada por qualquer dos pais e seus descendentes; 2) ampliação das formas de dissolução do casamento, ao estabelecer facilidades para o divórcio; 3) declaração da plena igualdade de direitos e deveres do homem e da mulher na convivência conjugal; 4) consagração da igualdade dos filhos, havidos ou não do casamento, ou por adoção, garantindo-lhes os mesmos direitos e qualificações.

Tais mudanças apenas foram possíveis na família, diante de fatos sociais, como, a independência econômica da mulher que, ao ingressar no mercado de trabalho, pode ao lado de seu companheiro, organizar e administrar a estrutura familiar. A preocupação com uma boa educação e formação dos filhos para que no futuro tivessem uma formação profissional e pudessem se colocar em uma boa posição no mercado de trabalho, proporcionou aos filhos maior desenvolvimento de sua capacidade intelectual e demais atributos pessoais, que lhes permitiu maior participação na vida familiar. $O$ divórcio trouxe a possibilidade do indivíduo infeliz em seu casamento, se desvincular daquela relação e recomeçar sua vida, amparado pelo ordenamento jurídico e, com isto trouxe a idéia da busca da felicidade pessoal.

A igualdade entre os cônjuges foi consagrada pela Constituição Federal de 1988, que não só estabeleceu a igualdade de direitos e deveres entre homem e mulher (artigo $5^{\circ}$, inciso I) como também, especificamente, estabeleceu em seu artigo 226, $\S 5^{\circ}$,

${ }^{25}$ DIAS, Maria Berenice. PEREIRA, Rodrigo da Cunha (coord.). Direito de Família e o novo código civil. Belo Horizonte, Del Rey, 2005, prefácio pág. X. 
que "os direitos e deveres referentes à sociedade conjugal são exercidos igualmente pelo homem e pela mulher". Homem e mulher passam a dividir as tarefas domésticas e, especialmente, passam a compartilhar as decisões a serem tomadas sobre o grupo familiar, fato que permite maior cumplicidade entre os cônjuges, que precisam do consenso, pois, em caso de conflito, não mais prevalece a vontade masculina.

Ressaltamos, no entanto, que a igualdade entre homem e mulher está adstrita aos direitos e obrigações legais. Sob o aspecto psicológico, as diferenças entre eles existem, assim como existem entre os seus semelhantes. Ninguém é igual, e esta diferença é que faz com que cada pessoa tenha uma personalidade distinta, e por isto seja única. Os cônjuges, então, a partir desta diferença, constroem uma identidade do casal.

Das diretrizes constitucionais extrai-se que os interesses da pessoa humana, integrante da família, recebe primazia sobre os interesses patrimoniais. A família, assim, configura-se no espaço de realização pessoal e da dignidade de seus membros. Permeiam a família os princípios da dignidade da pessoa humana, da afetividade, da liberdade e da solidariedade.

Para Denise Duarte Bruno, o afeto e a família são dois conceitos com características muito parecidas e se encontram intimamente ligados. Ambos são comumente referidos como dados, como fatos, embora sejam abstrações de difícil determinação. Neste sentido, quando finalmente rompemos com as definições biológicas e formais de família, concebendo-a como uma comunidade de afeto, a abstração dos termos nos leva a buscar elementos identificáveis nas práticas e na simbologia dos grupos sociais, que nos permitam reconhecer relacionamentos que possam ser nomeados de "família socioafetiva. $^{26}$

Quanto à importância do afeto, como novo paradigma das relações familiares, ressalta Giselda Maria Fernandes Novaes Hironaka,: “mas, acima de tudo, espalha-se a idéia de afetividade como o grande parâmetro modificador das relações familiais, estando a querer demonstrar que o verdadeiro elo das pessoas envolvidas nessas relações, nesse núcleo, nesse tecido, consubstancia-se no afeto. Não houve momento como este antes, seguramente. Não houve momento de reformulação das estruturas da família, através dos tempos, que tivesse dado o salto qualitativo em direção às emoções (performance maximamente otimizada do ser humano), sem ter de passar - obrigatória ou exclusivamente - pelas veredas de antes, quais sejam, o prumo político, a revisão social

26 BRUNO, Denise Duarte. Família sócioafetiva. Revista Jurídica Del Rey, Belo Horizonte : Del Rey/IBDFAM, n. 8, p. 27, maio 2002. (Número especial). 
e/ou o planejamento econômico. Dito de outra forma: nem só de arquétipos da modernidade vive a instituição da família, nos dias atuais; outras causas concorrem, ao lado daqueles, para apresentar a contextualidade que se impregna de mudanças e rupturas e que se tem considerado ser a "pós-modernidade"”, ${ }^{27}$

De fato, nos tempos atuais, a família identifica-se pela maximização do afeto, perdeu ela suas funções políticas, que emergiam da família patriarcal, marcante no Brasil Colônia e até o início do século XX. Desaparecidas as funções políticas, religiosas e econômicas da família, para as quais era imprescindível a origem biológica, pôde o grupo familiar cultivar a união por desejos e laços de afetividade, exaltando a excelência dos seus efeitos, a plena comunhão de vidas.

Atualmente, a família funda-se na igualdade, na liberdade de constituição e na convivência.

Porém, ressalta Waldyr Grisard Filho, que a família fundada na liberdade e nos interesses de seus membros, por não possuir traços de dependência entre os seus membros, poderão ter os laços de união poderão mais facilmente desatados: "o modelo de família atual, fundada na livre eleição do casal, no amor e no afeto, denota uma fragilização dos vínculos conjugais, pois, quando se instala o desamor, diminui a comunicação e desaparece o afeto, fracassam projetos biográficos comuns e desmoronam as ilusões, mais facilmente chega o divórcio através de fórmulas cada vez mais facilitadoras introduzidas pelo Estado-legislador. Este mesmo Estado, por outro lado, fortaleceu a solidariedade intrafamiliar mediante a afirmação constitucional da coresponsabilidade parental da proteção integral do menor,"28

Mas, é certo, que a união intrafamiliar, baseada na solidariedade, no afeto, no companheirismo e na liberdade é fortalecida pelo genuíno desejo de seus membros permanecerem juntos, o que, certamente, permite a construção de uma família formada em bases mais sólidas. Digamos, as pessoas permanecem juntas pela vontade de compartilhar a vida a dois e não por dependência ou imposição. Os laços de afeto estabelecidos são mais fortes e verdadeiros que outrora.

O divórcio, por sua vez, possibilita a dissolução dos vínculos cujo relacionamento não deu certo ante a impossibilidade de convivência dentro do lar conjugal.

\footnotetext{
${ }^{27}$ HIRONAKA, Giselda Maria Fernandes Novaes. A incessante travessia dos tempos e a renovação dos paradigmas: a família, seu status e seu enquadramento na pós-modernidade. In. DIAS, Maria Berenice e BASTOS, Eliene Ferreira. Família além dos mitos. Ed. Del Rey, Belo Horizonte, 2008, pág. 51.

${ }^{28}$ GRISARD FILHO, Waldyr. Famílias reconstituídas. Novas uniões depois da separação. Ed. Revista dos Tribunais. São Paulo, 2007, pág. 64.
} 
É fato que, com a facilitação do divórcio os vínculos familiares podem mais facilmente ser desatados, e, em uma sociedade dinâmica, as pessoas, muitas vezes, por motivos egoístas, preferem terminar seus relacionamentos a tentar conciliar os interesses do casal. Como veremos adiante, segundo estatísticas do IBGE, não obstante o número de divórcios seja expressivo, nestas últimas décadas o número manteve-se praticamente estável, o que significa uma mudança de comportamento da sociedade que aceitou o divórcio.

O Código Civil de 2002 à luz dos princípios e normas constitucionais, regulamenta, amplia e atualiza os aspectos essenciais do Direito de Família. Procurou o legislador adaptar-se à evolução social e aos costumes, ainda que, de maneira falha, em alguns pontos, cabendo, pois, aos operadores do direito aplicar os princípios constitucionais de forma consciente, de modo a atender os interesses da família, da sociedade e especialmente, da pessoa.

Para a integral aplicação do Direito de Família dentro das diretrizes constitucionais, o operador do Direito deverá fazer uma releitura do Direito Civil, valendose dos princípios como "normas jurídicas", convivendo com regras jurídicas. Ou seja, os princípios servirão como bússola orientadora do julgador na aplicação do direito, agora, visto, sob uma perspectiva civil-constitucional.

O Direito Constitucional define a moldura dentro da qual o intérprete aplicará o direito, possibilita-se, assim, a convivência entre princípios e normas jurídicas que, conjuntamente, nortearão o julgador na busca da justiça. É uma releitura do Direito Civil objetivando a aproximação entre direito e justiça.

Sobre o tema, explica Giselda Maria Fernandes Hironaka que: "E assim é porque o salto qualitativo que a pós-modernidade impôs ao direito, mormente o Direito Civil, correu no sentido da sua releitura, do seu reposicionamento espacial e temporal, estruturando-se com isso uma dimensão nova que reaproxima direito e ética. (...), os princípios alcançam outra esfera valorativa no contexto hermenêutico, pois eles ganham foros de "norma jurídica" (....) Os princípios, diferentemente, abrem os seus horizontes porque pretendem ser realizados amplamente, embora dentro dos naturais limites da possibilidade jurídica existente no caso concreto. Os princípios são, enfim, a mais alta expressão da normatividade, porque a norma jurídica, como gênero, compreende os princípios e também as regras." 29

${ }^{29}$ HIRONAKA, Giselda Maria Fernandes Novaes. A incessante travessia dos tempos e a renovação dos paradigmas: a família, seu status e seu enquadramento na pós-modernidade. In. DIAS, Maria Berenice e BASTOS, Eliene Ferreira. Família além dos mitos. Ed. Del Rey, Belo Horizonte, 2008, pág. 57. 
No mesmo sentido, é a lição de Luiz Edson Fachin, que aludindo quanto à impossibilidade da formulação apriorística de um conjunto de conceitos, regras ou definições que sejam capazes de dar conta da complexa realidade que apresenta o conjunto das relações familiares no Brasil contemporâneo, diz que: “é por essa razão que, a rigor, hoje se tem, de família, de filiação, da paternidade e da maternidade, muito menos um conceito prévio, e muito mais um conceito que se constrói a posteriori. Tratar-se-á de uma das dimensões importantes da incidência dos princípios constitucionais da família, que é a incidência construtiva desses significados por meio da jurisprudência. Todavia, alerta o professor: "essa impossibilidade não significa dizer que não devamos ter um mínimo de estabilidade e previsibilidade jurídica, porque é fundamental, no Estado democrático de direito, o respeito irrestrito a uma principiologia axiológica de índole constitucional, o respeito irrestrito aos termos do contrato social, como a sociedade faz, politicamente livre, através de seus representantes." 30

Os princípios constitucionais passam a incidir de maneira direta e imediata, sem que isso represente desprezo sobre o legislador ordinário, embora alguns doutrinadores ainda digam, que a incidência direta e imediata dos princípios constitucionais nas relações interprivadas significaria preterir o legislador ordinário. Esta visão dos princípios constitucionais, hoje, já está superada.

Os princípios, por trazerem conceitos e idéias amplas, permitem a construção de um direito mais atual, que, concomitantemente acompanha as transformações e os momentos vividos pela sociedade.

\section{A FAMÍLIA PÓS-MODERNA}

$\mathrm{Na}$ construção da família, atualmente, se acentuam as relações de sentimentos entre os membros do grupo: valorizam-se as funções afetivas da família que se torna o refúgio privilegiado das pessoas contra as pressões econômicas sociais. É o fenômeno social da família conjugal, ou nuclear ou de procriação, onde o que mais conta, portanto, é a intensidade das relações pessoais de seus membros. ${ }^{31}$

A família reinventou-se socialmente e reencontrou sua unidade no afeto. É a afetividade, pois, que vem despontando como elemento nuclear e definidor da união

${ }^{30}$ Fachin. Luiz Edson. Princípios constitucionais do direito de família brasileiro contemporâneo. In. DIAS, Maria Berenice e BASTOS, Eliene Ferreira. Família além dos mitos. Ed. Del Rey, Belo Horizonte, 2008, pág. 121/123.

31 OLIVEIRA, J.L.C.; MUNIZ, F.J.F. Direito de família. `Porto Alegre. Sergio fabris editor, 1990, p. 11 
familiar, o que traz inúmeras questões que devem ser repensadas como a paternidade afetiva, as relações homoafetivas, o instituto da culpa no casamento, a inseminação artificial.

Nos dias atuais, família tanto pode aludir a um grupo social restrito - o que congrega pais e filhos que convivem, inclusive, o tipo monoparental formado por um só dos pais e seu filho ou filhos - como outro mais extenso, que compreende a todos os descendentes de um tronco comum, ao qual se acham ligados por um vínculo de parentesco consanguíneo dentro de limites pré-fixados na lei.

No sentido amplo do termo, família é o núcleo formado pelo casal e seus filhos e ainda seus parentes da linha reta e ou da colateral e afins como estabelecem os artigos 1.591 a 1.595 do Código Civil. E, no sentido restrito o grupo formado pelo pai, mãe e filhos, sendo o locus do exercício da autoridade paterna e materna e da prática da solidariedade e da fraternidade familiar.

A família em sentido jurídico engloba todas as pessoas unidas por um laço de conjugalidade, parentesco ou de afinidade ao qual a lei atribui algum efeito jurídico. Nada obstante, a família está longe de ser uma entidade congelada, pois está permanentemente sujeita a movimentos e transformações sociais.

Lembramos que, a concepção de família, apenas como o grupo de pessoas unidas por laços de parentesco ou por matrimônio, está superada, vez que não compreende todos os modelos de família. Hoje temos uma pluralidade familiar, permitindo ao indivíduo adotar o modelo que se ajustar à sua forma de convivência e à privacidade de seus membros, uma vez que, a família tornou-se plural, na sua origem ou formação.

Em consonância com esta linha argumental, Marisa Herrera, explica que esta idéia sobre a sociedade atual - pós-moderna e globalizada - convida aos operadores do direito a revisar e ampliar o leque dos conteúdos que integram o direito de família. Diz a autora estar convencida que um dos primeiros passos consiste em reavivar o debate em torno do que é e o que se entende por família no século XXI. A respeito, lembra a autora, tem-se dito que a pluralidade de formas de constituição de família representa uma grande ruptura com o modelo único de família, instituído pelo casamento. Diz, ainda que é necessário aceitar outras formas de relacionamento que igualmente merecem proteção jurídica. É o princípio do pluralismo e da liberdade que vê personificar a sociedade pósmoderna. $^{32}$

\footnotetext{
32 “esta idea sobre la sociedad actual - posmoderna y globalizada - nos conmina a los operadores del derecho a revisar y ampliar el abanico acerca de los contenidos que integran hoy el derecho de família. Así, estoy
} 
Numa época de mudanças, o que não significa, naturalmente, o fim da clássica forma de família nuclear - que não pode mais servir como único paradigma para a sociedade - elaboram-se novas e variadas estruturas familiares.

No ajuste da família atual, uma maior possibilidade de modelos se apresenta, assumindo a família um "desenho plural, aberto, multifacetário e globalizado, servindo como locus privilegiado para o desenvolvimento da personalidade humana", no dizer de Cristiano Chaves de Faria, que encaminha suas conclusões para dizer que o atual ambiente da pós-modernidade: "é o ambiente ideal para a realização espiritual e física do ser humano, ou seja, somente se justifica a proteção da família para que se efetive a tutela da própria pessoa humana. É, por conseguinte, a família servindo como instrumento para a realização plena da pessoa humana e não mais vislumbrada como simples instituição jurídica e social, voltada para fins patrimoniais e reprodutivos". ${ }^{33}$

Como registra a conceituada professora Giselda Maria Fernandes Novaes Hironaka, "a "foto" da família da pós-modernidade retrata muito além de suas funções simplesmente sociais, econômicas, ideológicas, reprodutivas, religiosas, morais. Ela retrata também os projetos pessoais de cada um de seus membros, na busca pela sua realização e felicidade, sem perder de vista, contudo, a mesma projeção para o todo familiar. Isso porque a sociedade de hoje é assim. Os homens de hoje estão assim. A vida é esta e as condutas humana assim são realizadas. E, "uma vez que a família está inserida em uma sociedade, ela não pode ficar à parte das alterações sociais", assim como, por outro ângulo, “ a sociedade não pode ficar alheia às mudanças no meio familiar". ${ }^{34}$

A família atual difere dos modelos de família existentes no passado. Não apenas quanto as relações de autoridade e poder, mas especialmente quanto sua estrutura e formação, baseada no afeto que as modelou como hoje a reconhecemos.

convencida que uno de los primeros pasos consiste em reavivar el debate em torno a qué es o qué se entiende por família em los albores del siglo XXI. Al respecto, se ha expressado que: la pluralidad de formas de constitución de família representa uma gran ruptura com el modelo único de família, instituído por el casamiento. Aceptar otras formas de relaciones merecen igualmente, protección jurídica reconociendo El princípio de pluralismo y de liberdad que vê personificar la sociedad posmoderna"HERRERA, Marisa. Filiación, adoptión y distintas estructuras familiares em los albores del siglo XXI. In. DIAS, Maria Berenice e BASTOS, Eliene Ferreira. Família além dos mitos. Ed. Del Rey, Belo Horizonte, 2008, pág. 151/200.

33 FARIA, Cristiano Chaves. A família da pós-modernidade: mais que fotografia, possibilidade de convivência.

Disponível http://www.juspodivm.com.br/novo/arquivos/artigos/civil_família/artfamilia4.pdf

34 HIRONAKA, Giselda Maria Fernandes Novaes. A incessante travessia dos tempos e a renovação dos paradigmas: a família, seu status e seu enquadramento na pós-modernidade. In. DIAS, Maria Berenice e BASTOS, Eliene Ferreira. Família além dos mitos. Ed. Del Rey, Belo Horizonte, 2008, pág. 65 
De maneira muito sensível nos ensina Waldyr Grisard Filho ${ }^{35}$ : "Está claro que, por suas variadas origens, graus, natureza e versões multifacetadas dos diversos recantos do ordenamento jurídico, torna-se um desafio interminável toda tentativa de reunir em um só conceito sua máxima significação: o locus do amor, sonho, afeto e companheirismo, o lugar de elaboração da identidade da personalidade humana. Neste sentido se diz que a família é convivência orientada pelo princípio da solidariedade em função da afetividade e laços emocionais conjuntos. A família é a comunidade de vida material e afetiva de seus membros, que permite a subsistência, o desenvolvimento e o conforto deles, assim como o intercâmbio solidário, a mútua companhia, o apoio moral e afetivo para alcançar o desenvolvimento pessoal, a autodeterminação e a felicidade para cada um".

A transformação do direito de família, em razão das alterações em seu núcleo estrutural, consolidou-se na elaboração dos direitos da personalidade. O princípio da dignidade da pessoa humana, que passou a ser o fio condutor de todo sistema jurídico constitucional, privilegia, protege e insere a pessoa na realidade social, posto que se direciona ao homem concreto e individual com necessidades reais e que luta para conquistá-las.

O ser humano é o mesmo, contudo, seu papel mudou significativamente. O homem passou a considerar suas necessidades individuais e com isto alterou seus valores e suas projeções sociais. Relevante passou a ser a integração em um grupo, considerado o porto seguro do indivíduo, fonte de solidariedade, companheirismo e amor, na busca de sua felicidade.

A família, antes de ser um conceito jurídico, é uma realidade sociológica, assim, não mais é possível pensá-la sem ter em mente esta nova dimensão constitucional repleta de princípios direcionados à família.

Gustavo Tepedino, ao tratar das alterações sofridas pela família ao longo dos tempos, lembra que, apesar da mudança dos costumes e da história, a idéia de família é imortalizada, parecendo não mudar nunca: “a atávica necessidade de cada um de nós sente de saber que, em algum lugar, encontra-se o seu porto e o seu refúgio, vale dizer, o seio de sua família, este locus que se renova sempre como ponto de referência central do indivíduo na sociedade; uma espécie de aspiração à solidariedade e à segurança que dificilmente pode ser substituída por qualquer outra forma de convivência social. Na idéia de família, o

${ }^{35}$ GRISARD FILHO, Waldyr. Famílias Reconstituídas: novas uniões depois da separação. Editora RT, 2007, pág. 29. 
que mais importa - a cada um de seus membros - é exatamente pertencer ao seu âmago, é estar naquele idealizado lugar onde é possível integrar sentimentos, esperanças e valores, permitindo, a cada um, se sentir a caminho da realização de seu projeto pessoal de felicidade." 36

Entretanto, apesar da consagração constitucional do princípio da dignidade da pessoa humana e do reconhecimento da união estável e das famílias monoparentais pelo Estado, os avanços não foram suficientes para atender às necessidades da sociedade, uma vez que a família regulamentada pelo Código Civil passa a representar limitada forma de convivência, deixando o legislador de observar expressamente uma importante realidade social: a família formada pelo afeto.

E este é o grande desafio: a compreensão da família plural, aberta, baseada no afeto, que está além da família codificada, além das regras existentes que emolduram os fatos. É relevante enxergar e aceitar as novas e mais diversas constituições familiares, descobrir as necessidades de seus integrantes, para então, poder protegê-los e ampará-los.

É necessária a construção sólida de um direito permanentemente renovado e em sintonia com os fatos sociais, em diálogo constante com os princípios que norteiam o direito de família e simultaneamente com o princípio da dignidade da pessoa humana.

Neste sentido, a preciosa orientação de Luiz Edson Fachin: “e há nessa tríplice dimensão - doutrinária, legislativa e jurisprudencial - o desafio de construirmos, nos próximos dez anos, um novo paradigma hermenêutico do Direito de Família brasileiro contemporâneo. Esse novo paradigma de compreensão, novo paradigma do Direito de Família brasileiro contemporâneo, será edificado por muitas vozes, pelas mãos daqueles que, com sensibilidade e legitimidade pelo exercício de sua prática, irão participar de debates e expor as suas opiniões, mas também, no cotidiano, fazer as suas tarefas, porque do caso concreto também emerge um conjunto de percepções teóricas que são relevantíssimas." ${ }^{37}$

Em geral, o ordenamento jurídico vem depois das transformações sociais, motivo pelo qual, quase sempre existe certa defasagem entre as necessidades dos

\footnotetext{
${ }^{36}$ TEPEDINO, Gustavo. Novas formas de entidades familiares: efeitos do casamento e da família não fundada no matrimônio. Temas de direito civil. Rio de Janeiro. Ed. Renovar, 1999, p. 326.

${ }^{37}$ FACHIN. Luiz Edson. Princípios constitucionais do direito de família brasileiro contemporâneo. In. DIAS, Maria Berenice e BASTOS, Eliene Ferreira. Família além dos mitos. Ed. Del Rey, Belo Horizonte, 2008, pág. 129.
} 
indivíduos e as leis em vigor. Os operadores do direito, especialmente os juízes, enquanto representantes da justiça, pelos poderes investidos pelo Estado, na aplicação do direito devem ajustar as normas à realidade social. Não que o poder dos magistrados deva ser ilimitadamente discricionário, mas que se possibilite a aplicação do direito com base nos princípios constitucionais, permeados de conteúdos essenciais dos direitos fundamentais, universais e inalienáveis, possibilitando, consequentemente, o desenvolvimento de uma jurisprudência que reflita a pluralidade de uma sociedade aberta.

Dúvida não pode existir, a tarefa dos operadores do direito doutrinadores, magistrados, advogados, promotores, legisladores - é construtiva. Foram grandes as conquistas alcançadas nos tribunais nestes últimos tempos com a construção de uma jurisprudência sólida, baseada em construções doutrinárias, que refletem conceitos renovados do direito de família coerente com a atual realidade social.

Observam, contudo, Maria Berenice Dias e Rodrigo da Cunha Pereira que "não é fácil absorver tantas transformações, pois toda a travessia é sempre acompanhada de turbulência, o que gera a tendência de ver esta revolução da família como seu fim. Para o Direito, as dificuldades são ainda maiores, visto ser um desafio a disciplina jurídica das relações de afeto e das seqüelas patrimoniais daí decorrentes, de tal modo que assegure e viabilize a organização social. É nesse imperativo categórico que está o 'convite a pensar' as novas representações sociais da família para compreendê-la neste novo século." 38

Não obstante a interferência direta do Estado na vida das famílias tenha diminuído significativamente, seja em razão das alterações sociais que abriram espaço para a autorregulamentação da família, seja pela desinstitucionalização da entidade familiar, seja em razão das alterações sociais, seja pela crescente privatização do Estado - quando atribui a entidades privadas funções típicas - ainda é o Estado protetor e regulador das entidades familiares, base da sociedade.

Conquanto a proteção estatal seja atualmente realizada à luz do princípio da dignidade da pessoa humana, respeitando o indivíduo e a individualidade de cada grupo, é de extrema importância que o ordenamento jurídico procure, de alguma forma, refletir as mudanças e alterações verificadas na sociedade, compreendendo as necessidades das pessoas, já que as instituições se modificam mais lentamente que os indivíduos.

\footnotetext{
${ }^{38}$ DIAS, Maria Berenice. PEREIRA, Rodrigo da Cunha (coord.). Direito de Família e o novo código civil. Belo Horizonte, Del Rey, 2005, prefácio, pág. viii.
} 
Esta a importância da construção de uma jurisprudência sólida e bem fundamentada, já que, geralmente este é o primeiro contato do Estado com os problemas e angústias vivenciados pelas famílias e pela sociedade. Nasce aí, a oportunidade de imediata resposta pela justiça de aplicar os renovados conceitos de direito de família, observando as novas bases em que formadas as famílias.

Esta construção, como dito, dependerá do olhar sensível de todos os operadores do direito, que, em conjunto, cada qual no desenvolver de seu trabalho, proporcionarão as bases para que o direito acompanhe as transformações da sociedade. 


\section{III - AS NOVAS ESTRUTURAS FAMILIARES: FAMÍLIAS RECONSTITUÍDAS}

\section{A FAMÍLIA PLURAL CONSTITUCIONALIZADA}

Não obstante a consagração constitucional do princípio da dignidade da pessoa humana e do reconhecimento da união estável e das famílias monoparentais pelo Estado, os avanços não foram suficientes para atender às necessidades da sociedade, uma vez que a família regulamentada pelo Código Civil passa a representar limitada forma de convivência, deixando o legislador de observar uma importante realidade social: as famílias reconstituídas.

É necessária a construção sólida de um direito permanentemente renovado e em sintonia com os fatos sociais, em diálogo constante com os princípios que norteiam o direito de família e simultaneamente com o princípio da dignidade da pessoa humana.

As famílias reconstituídas, todavia, ficaram alheias à regulamentação pelo legislador civil de 2002, conquanto tenham sido mantidas intactas as relações entre pais e filhos após a ruptura da sociedade conjugal dos pais. A família reconstituída aqui tratada deve ser identificada como a estrutura familiar originada de um novo casamento ou de uma nova união estável, depois de uma ruptura familiar, quando um dos integrantes do novo casal, ou ambos, possuem filhos de uma relação precedente.

A família reconstituída faz nascer uma estrutura complexa, que a família original não é capaz de explicá-la e, em razão de sua especificidade, deve-se estudá-la sob parâmetros próprios, já que sua estrutura não é objeto de regulamentação pelo Direito. Ressalte-se que as normas existentes na nossa legislação civil não atendem às necessidades das novas famílias, quer seja para dar-lhes legitimidade que supram suas preocupações.

Segundo Rodrigo da Cunha Pereira, "Jacques Lacan, em 1938, escrevendo para o tomo VIII da Encyclopédie Française, em seu texto "A Família" (atualmente publicado no Brasil com o nome "Complexos Familiais"), vem exatamente marcar a diferença, mostrando que a família não é um grupo natural, mas cultural. Ela não se constitui apenas por um homem, mulher e filhos. Ela é antes uma estruturação psíquica, onde cada um de seus membros ocupa um lugar, uma função. Lugar do pai, lugar da mãe, lugar dos filhos, sem entretanto estarem necessariamente ligados biologicamente. Tanto é 
assim, uma questão de lugar, que um indivíduo pode ocupar o lugar de pai sem que seja o pai biológico. Exatamente por ser uma questão de lugar, de função, que é possível, no Direito, que se faça e que exista o instituto da adoção. Da mesma forma, o pai ou a mãe biológica podem ter dificuldade, ou até mesmo não ocupar o lugar de pai ou de mãe, tão necessários (essenciais) à nossa estrutura psíquica e formação como seres humanos". ${ }^{39}$

De todos os grupos humanos, é a família o que desempenha papel primordial na transmissão da cultura. Como diz Lacan: "Se as tradições espirituais, a manutenção dos ritos e dos costumes, a conservação das técnicas e do patrimônio são com elas disputados por outros grupos sociais, a família prevalece na primeira educação, na repressão dos instintos, na aquisição da língua acertadamente chamada de materna. Com isso, ela preside os processos fundamentais do desenvolvimento psíquico, preside esta organização das emoções segundo tipos condicionados pelo meio ambiente, que é a base dos sentimentos, segundo Shand, mais amplamente, ela transmite estruturas de comportamento e de representação cujo jogo ultrapassa os limites da consciência." 40

A família existe antes do Direito e é a sua estrutura, em constante mutação, que nos interessa estudar e trazer para o Direito, posto ser a ciência que, ao longo dos anos vem regulamentando as relações mantidas entre os seus componentes. Busca-se, especialmente, sob o enfoque constitucional, ampará-la e protegê-la como grupo para que seus integrantes possam existir como cidadãos e como pessoas - na sua estruturação subjetiva. Esta a relevância da existência de um ordenamento jurídico atual.

Embora os fatos indiquem ter o direito caminhado para uma revisão de concepção e de estrutura, acerca da família, existem ainda falhas quanto ao amparo de todos os grupos familiares. Mas, mesmo assim, podemos notar, que a família de hoje tende a ser mais sincera, a família de hoje abre espaço para relacionamentos mais francos e diálogos mais abertos, consequentemente, admite as rupturas, sem necessidade de simulações e hipocrisias verificadas na história da família de outrora.

Nesta linha, Ricardo C. Perez Manrique, diz que a família somente se legitima quando permite amparar e proteger seus integrantes e assegurar o seu desenvolvimento. Do contrário, carece de legitimidade, o que autoriza a intervenção do Estado para proteger os mais desamparados. Esclarece o autor que se consagrou assim um

\footnotetext{
${ }^{39}$ PEREIRA, Rodrigo da Cunha. Direito de Família: uma abordagem psicanalítica. Belo Horizonte, Del Rey, 1997, pág. 25.

${ }^{40}$ LACAN, Jacques. Os complexos familiares. Trad. Marco Antonio Coutinho Jorge e Potiguara Mendes da Silveira Junior.Rio de Janeiro, Jorge Zahar, p. 13.
} 
patamar mínimo de proteção que é em si um objetivo e um meio de lograr o direito à felicidade de cada um dos integrantes. ${ }^{41}$

Em sintonia com os princípios constitucionais, deixa a família de ser percebida como mera instituição jurídica para assumir feição de instrumento para a promoção da personalidade humana. Passa, assim, a ser a família o lugar privilegiado, de afeto e entre-ajuda, em que a pessoa, amparada por seus familiares, desenvolverá sua personalidade, na busca da felicidade.

Neste contexto, Guilherme Calmon Nogueira da Gama esclarece que a família "é formação social, lugar-comunidade tendente à formação e ao desenvolvimento da personalidade de seus participantes; de maneira que exprime uma função instrumental para a melhor realização dos interesses afetivos e existenciais de seus componentes. Não há mais lugar, no mundo atual, para o Direito de Família aristocrático, ou seja, aquele que objetivava tutelar a família "legítima", detentora de patrimônio e da paz doméstica como valores absolutos, sem qualquer conteúdo ético e humanista nas relações travadas entre os partícipes de tal organismo familiar. ${ }^{42}$

A família atual se baseia no afeto e no amor construído entre os seus integrantes. É a solidariedade, o companheirismo, a vontade de busca do desenvolvimento e da felicidade, pessoal e alheia, é ainda, o crescimento e a união do grupo que mantêm a família unida. As relações entre os entes familiares são mais intimas e cúmplices.

Como se vê, a família já não tem como base a manutenção do patrimônio ou simplesmente a continuidade genética dos ascendentes. Mudou, portanto, a base familiar, que se deslocou da esfera patrimonial para a esfera afetiva. Mudaram as razões para a constituição de uma família - evidentemente que não a essência - eis que a vontade do homem, desde os primórdios sempre foi de se agrupar e procriar, razões que, por certo, foram mantidas intactas, mas deixou o homem de casar apenas para manter ou acrescentar o patrimônio da família, ou por interesses políticos, sociais ou econômicos da família. O homem passou a buscar na família a sua realização pessoal. Mudaram assim as formas de constituição de família e suas estruturas.

\footnotetext{
41 "La família solamente se legitima em cuanto permite amparar y proteger a sus integrantes y asegura el desarrollo de los mismos. De lo contrario carece de legitimidad, lo que autoriza la intervención Del Estado para proteger los más desamparados. Se há consagrado así un estándar mímino de protección, que es em si un objetivo y un médio para lograr el “derecho a la felicidad de casa uno de los integrantes”.MANRIQUE, Ricardo C. Perez. Nuevas formas familiares - Demografía Y Derecho de Familia. In. DIAS, Maria Berenice e BASTOS, Eliene Ferreira. Família além dos mitos. Ed. Del Rey, Belo Horizonte, 2008, p. 265/266.

${ }^{42}$ GAMA, Guilherme Calmon Nogueira. Das relações de parentesco. In. Direito de Família e o Novo Código Civil (coord. Rodrigo da Cunha Pereira e Maria Berenice Dias, Ed. Del Rey, belo Horizonte, 2001, pág. 82.
} 
Nestas circunstâncias, Giselda Maria Fernandes Hironaka, afirma que "os relacionamentos familiares contemporâneos - quer no nível da conjugalidade, quer no nível da parentalidade - se baseiam na primazia do amor, e suas características principais poderiam ser assim enumeradas a) são relações que se valorizam por si mesmas e não por condições exteriores da vida social e econômica; b) são relações que primam pelo que podem trazer de bom para cada um dos membros do núcleo familiar envolvidos; c) organizam-se pelo viés reflexivo, no qual a comunicação é aberta e tem base contínua; d) são relações que tendem a se verem mais focadas na intimidade, na cumplicidade e na confiança mútua; e) são relações que transformam a obrigação do contato constante em compromisso ético entre os seus partícipes". ${ }^{43}$

As mudanças da estrutura familiar são um fato e cabe à sociedade e ao ordenamento jurídico aceitá-las e protegê-las. Sérgio Gischkow Pereira, diz que "não há que temer o novo Direito de Família. Ao contrário, conduz ele a uma família mais igualitária, mais libertária, mais fraterna, mais solidária, menos hipócrita, mais autêntica, mais sincera, com mais amor, com maior companheirismo, com menos opressão e prepotência, mais saudável, menos produtora de transtornos mentais e psicológicos. Como as transformações na sociedade passam pelas transformações na família, aquelas qualidades haverão de, a longo prazo, impregnar o coletivo, com extraordinário progresso moral e de aperfeiçoamento das relações sociais." ${ }^{44}$

Esta família mais aberta, onde as relações entre seus integrantes são de igualdade e baseadas na solidariedade, fraternidade e especialmente no afeto merece atenção da sociedade e do ordenamento jurídico em todas as suas formações.

É tempo de se incluir determinadas estruturas familiares, dentre elas as famílias reconstituídas, apesar de serem uma realidade, por não terem ainda o seu lugar bem definido - até pouco tempo atrás sequer possuíam uma denominação -, ficaram alheias ao ordenamento.

\footnotetext{
${ }^{43}$ HIRONAKA, Giselda Maria Fernandes Novaes. A incessante travessia dos tempos e a renovação dos paradigmas: a família, seu status e seu enquadramento na pós-modernidade. In. DIAS, Maria Berenice e BASTOS, Eliene Ferreira. Família além dos mitos. Ed. Del Rey, Belo Horizonte, 2008, pág. 65.

${ }^{44}$ PEREIRA, Sérgio Gischkow. A igualdade na filiação biológica em face do novo sistema de direito de família no Brasil. In. Wambier, Teresa Arruda Alvim. Leite, Eduardo de Oliveira. Coord. Repertório de doutrina e jurisprudência sobre direito de família: aspectos constitucionais, civis e processuais. São Paulo, RT 1999, v. 4, pág. 400/401.
} 


\section{A SIGNIFICATIVA EXPRESSÃO DAS FAMÍLIAS RECONSTITUÍDAS}

Basta levantar alguns dados estatísticos para perceber-se que, cada vez menos, uma criança permanece até a idade adulta junto a ambos os pais biológicos e, em contrapartida, cada vez mais esta criança se criará com um dos pais e um seu novo cônjuge ou companheiro. Não seria exagero dizer que, nos próximos anos, a família dirigida por um só dos progenitores e a família reconstituída serão as famílias padrão em muitos lugares do mundo. ${ }^{45}$

No Brasil há um elevado contingente de famílias reconstituídas, o que justifica o estudo de sua estrutura, funcionamento e normas que regulamentam as relações interpessoais de seus integrantes, em especial as figuras maternas e paternas afetivas.

Até o início do século $\mathrm{XX}$ as famílias reconstituídas resultavam primariamente do novo casamento seguido à morte de um dos cônjuges, enquanto contemporaneamente elas nascem do novo casamento seguido ao divórcio, resultando em novos filhos e novas relações.

De acordo com a Estatística de Registro Civil relativa ao ano de 2007, publicada em 2008 pelo IBGE, a taxa de divórcio em 2007, quando se completou 30 anos da instituição do divórcio no Brasil, atingiu o pico da série iniciada pelo Instituto Brasileiro de Geografia e Estatística (IBGE), em 1984, e chegou a 1,49 por mil (1,49 divórcios por cada mil habitantes) crescimento de $200 \%$ em relação a 1984 , quando era de 0,46 por mil. Em números absolutos os divórcios concedidos passaram de 30.847, em 1984, para 179.342,em $2007^{46}$.

A elevação das taxas de divórcio revela uma gradual mudança de comportamento da sociedade brasileira, que passou a aceitar o divórcio com maior naturalidade e a acessar os serviços de Justiça de modo a formalizar as dissoluções. Somando separações e divórcios, houve 231.329 uniões desfeitas em 2007, uma para cada quatro casamentos. Em 2007, foram realizados 916.006 casamentos, crescimento de 2,9\% ante $\mathrm{o}$ ano anterior.

Observa-se, conduto, segundo os dados publicados pelo IBGE que nesta última década, ou seja, desde 1997, o número de divórcios manteve-se praticamente

${ }^{45}$ GRISARD FILHO, Waldyr. Famílias reconstituídas. Novas uniões depois da separação. Ed. Revista dos Tribunais. São Paulo, 2007, pág. 94.

${ }^{46}$ Dados extraídos da Estatística de Registro Civil relativa ao ano de 2007, publicada em 2008 pelo IBGE, no site da instituição. 
estável. Tal dado reflete que a aceitação da sociedade quanto ao divórcio já havia se concretizado na década passada, não havendo, pois, razão para um crescimento expressivo.

Em contrapartida, o número de casamentos realizados no país vem crescendo desde 2003. O número maior de casamentos decorre, em grande parte, de iniciativas de formalização de uniões consensuais, já que os casais têm sido incentivados pelo Código Civil renovado em 2002, e pelas ofertas de casamentos coletivos promovidos desde então. A pesquisa mostra que a taxa de nupcialidade legal atingiu, em 2007, o valor de 6,7 casamentos por mil habitantes, a maior taxa da série e equivalente a 1999.

As estatísticas mostram, também, que é crescente a proporção de casamentos de indivíduos divorciados com cônjuges solteiros. Os percentuais mais elevados são observados entre homens divorciados que casaram com mulheres solteiras, quando se compara com mulheres divorciadas que se uniram formalmente a homens solteiros. Esses percentuais passaram de 4,4\% para 7,1\%, no primeiro caso, e de 1,9\% para 3,7\%, no segundo, entre 1997 e 2007. Observou-se, ainda, o aumento de casamentos entre cônjuges divorciados, de 1,1\%, em 1997, para 2,5\%, em 2007.

Em 2007, em números absolutos, foram mais de 200.000 os casamentos realizados, nos quais ao menos um dos cônjuges teve união anterior.

Como se vê, os números são expressivos. O elevado número de divórcios, especialmente de pessoas na faixa etária entre 25 e 44 anos, têm contribuído diretamente com o aumento das famílias reconstituídas, que, como demonstra a estatística, contraem novo casamento, isto, sem considerar as uniões informais, mais frequentes nas segundas famílias.

É natural do ser humano buscar um companheiro para compartilhar a vida e um novo ambiente familiar, como um porto seguro para si e para seus filhos.

Registra Marisa Herrera, que, apelando para a inegável interação entre direito e realidade, dados estatísticos nos indicam o importante aumento e a magnitude dos lares encabeçados pela mulher, fenômeno que se estende em todo o mundo, como consciência do aumento do número de separações e divórcio. ${ }^{47}$

\footnotetext{
47 "nuevamente apelando a la innegable interacción entre derecho y realidad, datos estadísticos nos senalan “(...) El importante aumento em la magnitud de los hogares encabezados por la mujer, fenômeno que se extiende em todo el mundo, como consecuencia del incremento em el numero de separaciones y divórcios."HERRERA, Marisa. Filiación, adoptión y distintas estructuras familiares em los albores del siglo XXI. In. DIAS, Maria Berenice e BASTOS, Eliene Ferreira. Família além dos mitos. Ed. Del Rey, Belo Horizonte, 2008, pág. 174.
} 
O censo argentino de 2001 indica a existência de 300.000 famílias reconstituídas no país. Especialistas acreditam ser este número muito maior hoje, já que mais freqüentes este tipo de família ${ }^{48}$.

Somente na cidade de Buenos Aires existem mais de 35.000 famílias reconstituídas que representam 10,6\% das famílias compostas por pais e filhos. Os dados apontam que 53\% das famílias reconstituídas argentinas tem apenas os filhos das uniões anteriores, enquanto $47 \%$ tem filhos da atual união, sendo que $55,4 \%$ das famílias têm os responsáveis com idade entre 30 e 49 anos. Essas famílias são compostas na média por 4,5 pessoas, enquanto, a média da cidade é de 2,6 pessoas por família ${ }^{49}$.

Nos Estados Unidos os dados estatísticos apontam que cerca de $50 \%$ de todos os primeiros matrimônios terminam em divórcio, sendo que $75 \%$ de todos os divorciados casam-se de novo. Calcula-se que $46 \%$ de todos os casamentos nos Estados Unidos são o segundo casamento de pelo menos um dos cônjuges, a maioria, inclui crianças de uma relação anterior e 30\% tem filhos no segundo casamento. Os dados apontam que 50\% dos 60 milhões de crianças menores de 13 anos vivem com um pai biológico e com o novo companheiro de seu pai. ${ }^{50}$

O censo americano de 1990 projetou que, no ano de 2000, haveira mais famílias reconstituídas que famílias originais. Contudo, o censo americano de 2000 não fez menção às famílias reconstituídas. Segundo a 'Stepfamily Foundantion' 1300 novas famílias reconstituídas são formadas todos os dias nos Estados Unidos.

Os números expressivos de famílias reconstituídas se repetem no continente europeu. Na Inglaterra, um a cada três casamentos constitui novo matrimônio e $1 / 4$ das crianças cresce com um padrasto ou madrasta. Na Alemanha, $40 \%$ das mães se casam com outro homem que não é o pai de seus filhos. E, na Itália 70 a $80 \%$ dos divorciados voltam a se casar ${ }^{51}$.

$\mathrm{Na}$ Inglaterra, em 1940, 91\% dos casamentos foi o primeiro casamento para ambos os cônjuges, em 2007, este número caiu para $62 \%$, ano em que 88.010

\footnotetext{
${ }^{48}$ Dados extraídos do site http://blog.pucp.edu.pe/item/23019. Blog de Manuel Bermudez Tapia. Acesso em 02/10/2009.

${ }^{49}$ Dados extraídos do site http://clarin.com/diario/2008/06/08/sociedad/s-04015.htm. Acesso em 02/10/2009

${ }^{50}$ Dados extraídos dos sites: http://www.successfulstepfamilies.com/view/176, acesso em 29/09/20009 e http//:www.stepfamily.org/statistics.html, acesso em 29/09/2009.

${ }^{51}$ Dados extraídos da obra de Cecília P. Grosman e Irene Martinez Alcorta Familias ensambladas. Buenos Aires, Universidad, 2000, p. 46/52.
} 
casamentos foram o segundo, pelo menos para um dos cônjuges, representando $38 \%$ de todos os casamentos. ${ }^{52}$

É, pois, necessária uma reflexão renovada da família tradicional para se compreender a dinâmica da família reconstituída, que, cada vez mais, marca significativa presença na sociedade contemporânea, refletindo as transformações dos laços familiares.

O tema tem preocupado especialistas nas áreas psico-socias, mas escassamente tem sido tratado pelo direito, que permanece silencioso, diante da magnitude e da realidade dessas famílias em muitos lares brasileiros. Não cabe ao direito ignorar essas famílias em nossa sociedade.

O Estado não pode mais controlar as formas de constituição das famílias. Ela é plural. A família pode ser formada por várias espécies, dentre as quais exemplificativamente citadas pelo legislador constituinte - a formada pelo casamento, pela união estável e pela comunidade dos pais e seus descendentes. Estas e outras formas de constituição familiar vêm exprimir a liberdade dos sujeitos de se agruparem da forma que lhes convier, no espaço de sua liberdade.

Registram Cláudia Lima Marques, Maria Cláudia Cachapuz e Ana Paula da Silva Vitória: "Em suas aulas na Universidade Federal do Rio Grande do Sul, em setembro de 1996, Erik Jayme comentava o individualismo crescente na família, com o direito passando a valorar de forma tão destacada os direitos individuais, os direitos pessoais e, mesmo, os direitos fundamentais dos membros desta instituição; que se a família não deixa de ser um todo, perde em força, perde em caráter de união, porque nenhum de seus membros quer mais fazer sacrifícios para estar integrado em uma família. Cada membro da família quer sim e vai manter-se plenamente pessoa, sujeito de direitos, apesar de integrar-se neste grupo social. O nascimento ou reconhecimento de novos sujeitos na família inverte o ponto de concentração do direito, da instituição como um todo, para as partes, para os sujeitos individualmente considerados, em um novo pluralismo de sujeitos". 53

Pelos números apresentados constatamos serem as famílias reconstituídas uma realidade na sociedade as quais merecem atenção dos operadores do direito, especialmente, se considerarmos as novas bases de estruturação da família atual, que é plural e afetiva.

${ }^{52}$ Dados extraídos do site: http//:www.statistics.gov.uk, acesso em 29/09/2009.

${ }^{53}$ MARQUES, Claudia Lima; CACHAPUZ, Maria Cláudia (col.) VITÓRIA, Ana Paula da Silva (col.). Igualdade entre Filhos no Direito Brasileiro Atual - Direito Pós-Moderno? Revista dos Tribunais, São Paulo, v. 764, 1999, pág. 17. 


\section{FAMÍLIA RECONSTITUÍDA: UMA ESTRUTURA COMPLEXA}

Cabe aqui realizar algumas considerações sobre a família reconstituída e a importância dos vínculos de afetividade criados no seio da família, decorrentes da convivência e da solidariedade.

Para iniciar a explicação das complexas relações existentes na família reconstituídas, com o intuito de traçar uma relação de parentesco entre pais e filhos afins, lembramos que o legislador acolheu a expressão parentesco por afinidade, enaltecendo o conteúdo afetivo amplificador das relações familiares.

Pode-se dizer que a afinidade é uma classe de parentesco que nasce do laço convivencial válido. É o vínculo que se estabelece entre um cônjuge ou companheiro e os parentes do outro, na linha reta e colateral, conforme preceitua o disposto no artigo 1.595 do Código Civil de 2002.

Mas é a afetividade une o grupo familiar que compartilha o mesmo lar. As relações se estabelecem entre cada um dos membros fazendo com que filhos se sintam irmãos e os cônjuges se sintam como "pais" do filho do outro. Esse sentimento simboliza a existência de um laço afetivo que evita desordem e confusão familiar.

Assim temos que o vínculo familiar pleno decorrente da solidariedade familiar é concretizado pelas emoções, dedicação, esforço e assistência entre os membros presentes no cotidiano da família.

Toda família funciona como um sistema mediante convenções, regras que determinam o modo de interagir de seus membros entre si e com o meio social em que se inserem, de acordo com as diversas etapas do ciclo da vida familiar. A família está em constante e radical transformação. Não obstante isto, a estrutura deste sistema familiar garante a seus membros uma proteção psico-social, seja como uma unidade coesa, oferecendo continuidade e sentido de posse, seja como uma estrutura diferenciada, possibilitando o pleno desenvolvimento individual e a formação da identidade própria de cada integrante. ${ }^{54}$

Portanto entre os filhos do outro cônjuge e o cônjuge pode-se legitimamente atribuir um vínculo familiar pleno, fundado na solidariedade familiar. Se é

\footnotetext{
${ }^{54}$ GRISARD FILHO, Waldyr. Famílias reconstituídas. Novas uniões depois da separação. Ed. Revista dos Tribunais. São Paulo, 2007, pág. 85.
} 
pleno, o vínculo é perpétuo, projetando os efeitos dele decorrentes para além do casamento ou da união o que implica diversas responsabilidades.

A estrutura da família reconstituída implica a fusão de duas ou mais famílias com características e modos de relação diferentes em que circulam e convivem crianças e adolescentes de distintos casamentos e convivências, criando múltiplos vínculos.

Define, Waldyr Grisard Filho, a família reconstituída como “a estrutura familiar originada do casamento ou da união estável de um casal, na qual um ou ambos de seus membros têm um ou vários filhos de uma relação anterior. Numa formulação mais sintética, é a família na qual ao menos um dos adultos é um padrasto ou uma madrasta. Ou, que exista ao menos um filho de uma união anterior de um dos pais. Nesta categoria entram tanto as sucessivas uniões de viúvos e viúvas como de divorciados e divorciadas com filhos de uma relação precedente e as primeiras de mães e pais solteiros. Alude, assim, não só a reconstituição como ao estabelecimento de um novo núcleo familiar, no qual circulam crianças de uma relação dissolvida. Um posterior relacionamento implica a fusão de duas ou mais famílias com características e modos de interação diferentes. A possibilidade de que um grupo familiar reconstituído funcione com um baixo nível de conflitos dependerá da disponibilidade de que seus membros aceitem um modelo familiar distinto do anterior e que as relações entre seus membros sejam permeáveis. Os filhos deste tipo de relação experimentam dificuldades com relação aos limites, o espaço e o tempo que se lhes dedica e a autoridade a que devem obedecer, porque implica passar de um modelo a outro (de um nuclear a outro binuclear), em que antigas pautas seguem vigente junto a novas". 55

Frise-se, esta conceituação contempla não só o núcleo formado pelo genitor que detém a guarda dos filhos de uma relação anterior, mas também o formado pelo genitor que não a detém, dado o vínculo de afinidade ( $\$ 1^{\circ}$ do artigo 1.595 do Código Civil), compreendendo, também, os núcleos formados por relações de união estável.

Para alguns demógrafos americanos, entretanto, só é padrasto ou madrasta o cônjuge do genitor guardião, mas não quem se uniu ao pai ou a mãe que não vive com seus filhos, limitando o conceito de família reconstituída. Assim, pensa-se a família em termos de "grupo doméstico" que compreenderia todos que vivem em um lar: o novo casal, os filhos de um ou de outro, provenientes de uma união anterior e os filhos da nova união. Já na França a noção é mais abrangente, vez que engloba todo o sistema

\footnotetext{
${ }^{55}$ GRISARD FILHO, Waldyr. Famílias reconstituídas. Novas uniões depois da separação. Ed. Revista dos Tribunais. São Paulo, 2007, pág. 78.
} 
familiar integrado pelo novo núcleo que se constitui articulado com os vários subsistemas familiares anteriores, aí incluídos o lar do genitor guardião e do genitor não guardião e os afins de cada um deles. Neste sistema, as crianças são o centro da família, sendo ignoradas as fronteiras que separam os lares.

Com o aumento dos divórcios e de separações e o aparecimento de novas uniões posteriores às primeiras, temos que a família reconstituída acomoda uma extensa rede de relações, integrando o novo núcleo a outros precedentes. Na família tradicional, os laços de parentesco são bem definidos, pai e mãe, irmãos, avós, tios, primos. Na família reconstituída, porém, surgem novos laços de parentesco, multiplicando as pessoas que ocupam os mesmos lugares e exercem funções semelhantes, aumentando as dificuldades iniciais de entendimento destas relações. E essas dificuldades tornam-se maiores quando inexistem nomes estabelecidos para a grande maioria destes sujeitos.

A própria nomenclatura utilizada para designação desta nova estrutura familiar: "família reconstituída", já nos orienta no sentido de que "re-constituir" significa "construir de novo". O novo grupo familiar criará novos vínculos afetivos, sociais e jurídicos.

Waldyr Grisard Filho, explica que "ora os autores se referem ao "novo casamento" (remarriage), ora à família reconstituída (reconstituted family), ora à família recomposta (blendend family). $\mathrm{O}$ fenômeno abrange tanto as uniões legítimas quanto as uniões de afeto, sem as confundir, mas levando em consideração o ponto comum que lhes é peculiar. Ainda, nem todos os casados novamente constituem, necessariamente, famílias reconstituídas; é necessário que, no mínimo se verifique, no novo lar, a ocorrência de filhos oriundos de uma união anterior, de um outro genitor, ou porque o processo pode englobar tanto a nova união de viúvos, quanto a de genitores separados, ou oriundos de um divórcio, com filhos exclusivos de um só genitor ou de ambos."

$\mathrm{Na}$ argentina é utilizado o termo 'família ensamblada', para designar as famílias por nós chamadas de reconstituídas. 'Ensamblada' segundo o dicionário, vem de 'ensamblar', cuja tradução para a língua portuguesa é 'encaixar', 'embutir'. 57

A denominação 'famílias ensambladas' provém da linguagem musical. Os 'ensambles' são obras musicais escritas para um grupo de solistas e a palavra não apenas se refere ao conjunto musical como também descreve o grau de coerência com a

\footnotetext{
${ }^{56}$ GRISARD FILHO, Waldyr. Famílias reconstituídas. Novas uniões depois da separação. Ed. Revista dos Tribunais. São Paulo, 2007, pág. 10.

${ }^{57}$ Dicionário Espanhol-Português Michaelis, Ed. Melhoramentos, 2002.
} 
execução musical, e o resultado do esforço de todos, proporciona algo harMônico e gratificante tanto para os músicos como para o auditório. Esta metáfora se popularizou e foi adotada pela doutrina ${ }^{58}$.

Para Marisa Herrera ${ }^{59}$, citando Cecília P. Grosman, a nomenclatura que melhor se ajusta a esta estrutura familiar é "familia ensamblada", e, assim, explica e justifica a razão de sua escolha: depois de uma separação, divórcio ou viuvez, quando ambos os integrantes do casal tem filhos de uma união anterior, elegemos esta denominação, entre tantas outras que circulam no meio social e científico, como famílias reconstituídas, famílias recompostas, famílias rearmadas ou segunda família, porque simboliza com maior precisão os intercâmbios que tem lugar entre o novo núcleo que se constitui e os grupos familiares precedentes.

A língua inglesa dispõe de um termo próprio para nominar e reconhecer esta nova forma de organização familiar: 'step family' ou 'blended family', designada na linguagem comum a família na qual um dos adultos, ao menos, é um padrasto. Não há termo correspondente na língua portuguesa.

Os primeiros estudos sobre as famílias reconstituídas foram realizados pelas ciências psico-sociais, que atribuíam distintas denominações como, família reconstituída, família recomposta (famille recomposée, para a doutrina francesa), família transformada, família rearmada, família agregada, família agrupada, família combinada ou mista, família extensa, família ensamblada (para a doutrina dos países de língua espanhola), sequênciais ou mesmo em rede.

Ora, a própria diversidade de designações já evidencia a dificuldade de encontrar um nome próprio, que conceitue esta estrutura familiar complexa, demograficamente expressiva.

Anota Waldyr Grisard Filho que "à míngua de um termo específico e comum para denominar os novos vínculos, alguns terapeutas e psicólogos a definiam por comparação (segundas ou posteriores núpcias) ou por negação (não intactas, não

\footnotetext{
${ }^{58}$ DAMENO, Maria Silvia. Mujeres en famílias ensambladas.

59 "después de uma separación, divorcio o viudez, cuando uno o ambos integrantes de la pareja tienen hijos de uma unión anterior. Agregándonse que "Hemos elegido esta denominación, entre tantas otras que circulan em el médio social y cientifico, como "las famílias reconstituídas", "las familias recompuestas", "las famílias rearmadas" o las "segundas famílias", porque simboliza com mayor precisión los intecambios que tienen lugar entre el nuevo núcleo que se constituye y los grupos familiares precedentes" HERRERA, Marisa. Filiación, adoptión y distintas estructuras familiares em los albores del siglo XXI. In. DIAS, Maria Berenice e BASTOS, Eliene Ferreira. Família além dos mitos. Ed. Del Rey, Belo Horizonte, 2008, pág. 163.
} 
biológicas), indicando com ambas opções a desvalorização da nova família. Deste modo, sem uma peculiar denominação, só contribui à sua própria invisibilidade estatística, social e jurídica". E assim, justifica a opção, em seus estudos, pela utilização do termo família reconstituída: "dentre as denominações propostas, a de famílias reconstituídas enquanto ser a expressão constituir a mais corrente na doutrina (constituir uma família, constituir o estado de casado), no sentido de ser a base de uma nova família, pela dissolução da precedente. Não no de conciliar, como denota o verbo compor, do qual deriva a denominação família recomposta, menos próprio. O prefixo 're' denominação eleita, embora possa sugerir a repetição da família anterior, significa antes uma mudança de estado, o que, evidentemente, não é o mesmo que estabelecer outra vez a situação prévia, na medida em que novos membros a ela se integram, com desapreço ao cônjuge ou companheiro anterior". 60

Adotamos, na linha exposta por Waldyr Grisard Filho, para o presente estudo, a nomenclatura 'família reconstituída', especialmente pela idéia de mudança de um estado, para a construção de uma nova família.

De extrema importância a utilização de nova denominação que identifique esta nova estrutura familiar, possibilitando a sua identificação nos distintos âmbitos da vida cotidiana, institucional e científica. Continuar a chamar estas famílias, só famílias, supõe uma conduta social de ocultamento e não discrimina as diferenças relacionadas com a especificidade dos novos vínculos tanto no social e afetivo, como no jurídico.

Até mesmo na qualificação dos novos integrantes surgem as primeiras dificuldades, em especial para as crianças pequenas, que desde cedo conviveram com o cônjuge do pai biológico, na medida em que possuem a figura de dois "pais", duas "mães", quatro "avôs", quatro "avós", novos irmãos, primos, tios, etc.

Necessária, assim, a designação dos integrantes dos vínculos que se formam entre um dos cônjuges e os filhos do outro, pois é esta relação que constitui o eixo central das famílias reconstituídas. Até então, a referência do novo marido da mãe ou da mulher do pai era de padrasto e madrasta e os filhos, enteados.

Todavia, as nominações de padrasto e madrasta ao cônjuge da mãe ou do pai não seriam a melhor expressão para designar os pais e mães afins. As figuras dos padrastos e madrastas, desde a memória infantil são associadas a pessoas más, egoístas e

${ }^{60}$ GRISARD FILHO, Waldyr. Famílias reconstituídas. Novas uniões depois da separação. Ed. Revista dos Tribunais. São Paulo, 2007, pág. 82. 
cruéis, como relatam os contos infantis, lembre-se apenas das tradicionais histórias da Cinderela e Branca de Neve.

Anotamos, ainda, que antigamente, padrastos e madrastas só existiam quando alguém morria, exprimindo a relação de parentesco firmado entre os filhos de uma viúva e a pessoa com quem contraísse novo casamento ou a mulher que casava com o viúvo, em relação aos filhos deste, havidos de casamento anterior.

Observa-se, assim, no cotidiano, grande resistência em nomear os pais e mães afins. O tratamento dependerá da idade dos filhos e do relacionamento criado dentro daquele núcleo familiar. Por vezes os pais afins são tratados como 'tios', como 'marido da minha mãe', 'esposa do meu pai', 'filha do meu marido', 'filho da minha esposa', quando não, são apenas designados pelo nome próprio, sem nada revelar quanto à relação existente.

Diferente é a situação quando o vínculo se estabelece desde cedo, especialmente, quando a família se forma em razão da ausência de um dos pais biológicos, quer em razão de falecimento do pai biológico, quer por simples ausência, quando, então, o pai ou mãe afim assume integralmente a função parental. Nestes casos, é alta a probabilidade dos pais afins serem verdadeiramente tratados como pais.

Como se observa, não se trata de simples questão terminológica, no caso, carregada de desprestígio e negatividade, mas de situar uma pessoa no novo entorno familiar e social.

Os sujeitos nestas famílias experimentam enormes dificuldades em relação ao tempo, espaço e autoridade que lhes correspondem, pois cada um tem sua própria história. Com a nova família surgem novas regras que precisam se ajustar às anteriores de cada grupo para criar regras próprias ao novo grupo, gerando sua identidade.

Quanto ao tema, lembra Waldyr Grisard Filho que: "desde a origem da sociedade humana organizada surge a família como entidade fundada em regras - dada à necessidade de organização de um sistema, com base religiosa, social e econômica. No plano dos sistemas jurídico romano-germânico, o núcleo familiar primário - pai-mãe-filhos - tem estabelecido claramente os papéis e as funções, as responsabilidades, os direitos e os deveres para cada um de seus membros. Contudo, toda esta normatização não cobre as demandas e as expectativas dos integrantes das várias formas de família que surgem no cenário social contemporâneo, como resultado da menor estabilidade do laço conjugal.." 61

\footnotetext{
${ }^{61}$ GRISARD FILHO, Waldyr. Famílias reconstituídas. Novas uniões depois da separação. Ed. Revista dos
} Tribunais. São Paulo, 2007, pág. 15. 
O pluralismo familiar, como forma de reconhecimento de diversas composições familiares, quebra o paradigma da exclusividade do modelo padrão e implica aceitação de novas estruturas familiares na sociedade, especialmente como consequência da facilitação e da frequência cada vez mais elevada das separações e divórcios, que possibilita um novo contexto sócio-jurídico, de fronteiras permeáveis e tormentoso, e, por isto mesmo, gerador de questões ainda não enfrentadas pelo direito, no qual estão inseridas as famílias reconstituídas.

No processo de concepção da família reconstituída forma-se uma estrutura complexa, formada por múltiplos vínculos de seus membros pertencentes a sistemas familiares provenientes de uniões anteriores. As crianças podem passar a ter novos irmãos que, mesmo sem qualquer vínculo anterior, passam a ser assim tratados pelo funcionamento da família no cotidiano. Pais e mães afins cumprem suas funções muitas vezes sobrepondo-as às dos pais biológicos. Aparecem novos tios e avós, provenientes de outras famílias. O círculo social se expande e surgem crises e conflitos de autoridade e lealdade, o que exige o estabelecimento de acordos para uma interação estável no tempo e flexível em sua formulação.

O elo entre o cônjuge ou o companheiro e os filhos do outro é o que define as famílias reconstituídas. Logo a maior preocupação no seio da família reconstituída concerne, especialmente, no tocante ao múnus inerente aos pais em relação aos filhos, o qual detém natureza tão complexa e peculiar, e em que permeiam todas as etapas do desenvolvimento dos filhos.

A regra na família tradicional é que na constância do casamento os genitores, em conjunto, devem exercer o poder familiar. Nesta etapa o poder está concentrado e não gera maiores dificuldades. As dificuldades surgem com a separação, quando este poder se diluiu, e as dificuldades se agravam, quando surge uma terceira família constituída após a separação.

No Direito a verdade biológica, por muito tempo, converteu-se na "verdade real" da filiação em decorrência de fatores históricos, religiosos e ideológicos que estiveram no cerne da concepção hegemônica da família patriarcal e matrimonializada. Legítimo era o filho biológico nascido na constância do matrimônio dos pais.

Destarte, nas famílias reconstituídas cujas fronteiras são imprecisas e a condição de membro não é claramente definida, não existem normas que orientem as condutas de seus integrantes. O homem pode assumir o papel de "pai" até simplesmente de o outro adulto da casa. 
Os adultos procuram cumprir suas funções, mas como não tem claro seu papel, muitas vezes acabam por sobrepor-se aos pais biológicos, embora vivos estes, fazendo aparecer conflitos de autoridade e lealdade.

Isto porque, como ensina Waldyr Grisard Filho, “sempre haverá um pai ou uma mãe presente ou na lembrança de cada filho, cuja existência como tais se mantém, apesar da ruptura do casal conjugal. A nova família deverá conviver com a presença, real ou virtual, de um ex-esposo ou de uma ex-esposa. Mesmo aquele pai ou aquela mãe que nunca visita o filho ou que está morto, é parte de sua história, e este necessita manter um vínculo ou lembrança deles. Um pai afim ou uma mãe afim pode não tolerar que o filho afim ou filha afim veja fotos, cartas atenda ao telefone ou receba a visita do pai ou mãe biológico. Quando os membros da família são ambos divorciados, impõe-se conciliar as suas necessidades com as da co-parentalidade com ex-parceiro e muitas vezes implica contactos e negociações para compartilhar dois lares, com escolas de valor e hábitos de vida diferentes, limitando a liberdade de decisão sobre os filhos do outro cônjuge ou companheiro". 62

Mas o que nos interessa para o presente estudo é que na verdade pais e mães afins assumem uma responsabilidade parental antes mesmo que se crie um vínculo emocional com o menor, conquanto a grande dificuldade seja estabelecer em quais condições surge esta responsabilidade e quais os seus limites.

Inúmeras são as dúvidas inerentes aos integrantes deste tipo de estrutura familiar e diversas são as questões a serem respondidas. Detém o cônjuge ou companheiro autoridade sobre os filhos do relacionamento anterior de seu companheiro? Tem responsabilidade sobre os filhos de seu companheiro? Possuem alguma obrigação econômica?

Para os filhos, então, surgem dúvidas e conflitos, quanto ao espaço físico, sobre quem são os membros de sua família, sobre a autoridade: quem é o responsável pela disciplina, pelas decisões, pelo dinheiro? Obedecer ao companheiro de seu pai/mãe é negar a autoridade do seu pai/mãe biológico?

Os conflitos são inúmeros, contudo, com o decorrer do tempo, a convivência torna estes vínculos uma realidade. O pai ou mãe sem ser de sangue se torna afim não só pelo parentesco, mas pela afetividade, pela convivência diária, pela solidariedade, pelos laços afetivos. Não raramente o nexo psicossocial torna-se até mais

\footnotetext{
${ }^{62}$ GRISARD FILHO, Waldyr. Famílias reconstituídas. Novas uniões depois da separação. Ed. Revista dos Tribunais. São Paulo, 2007, pág. 88.
} 
forte que o biológico. A posse de estado de filho/pai será a exteriorização da convivência familiar e da afetividade.

Importante lembrar que, atualmente, nas relações entre pais e filhos, o traço autoritário passou a ceder espaço para o tratamento igualitário, abrindo a possibilidade de decisões conjuntas.

Até porque a convivência entre pais e filhos, na sociedade brasileira atual, é mais duradoura, considerando-se que os filhos, por razões especialmente econômicas, deixam os lares conjugais mais velhos que outrora, quando já puderam minimamente se estruturar.

Sobre este fenômeno, comenta a professora Giselda Maria Fernandes Hironaka: "um fenômeno interessante de ser anotado é aquele que mostra que os filhos já não saem de seus lares originais tão logo deixem a adolescência, como foi comum no modelo de família imediatamente anterior a esse. Aquela expectativa que corria alegremente, há bem poucas décadas, a favor do momento de se alcançar a maioridade, já não se repete hoje, e os filhos se tornam adultos "sem passar para a idade adulta", como é o interessante dizer de Elza Ramos, prolongando a coabitação entre gerações por razões que não foram consideradas ou vivenciadas nas sociedades anteriores a esta, como o prolongamento dos estudos, as dificuldades econômicas, o mercado de trabalho mais fechado, por exemplo. Mas o lado positivo dessa permanência por mais tempo em casa, conforme apurado, é que há um convívio diferenciado, pois as gerações (avós, pais e filhos) passam a ter a oportunidade distinta de conviver, estando os mais jovens com a definição de suas faixas etárias para além da infância e da adolescência, o que pode tornar o diálogo bem mais facilitado, ao menos na maioria dos casos". ${ }^{63}$

Assim, sendo as relações entre pais e filhos mais igualitárias do que de poder, podem os mais velhos e os mais jovens conviver mais produtivamente, permitindo uma maior troca entre as gerações. Logo, as relações hierárquicas, antes baseadas na obediência aos modelos de repetição tradicional, cedem espaço para os novos paradigmas norteadores das relações parentais no seio da família contemporânea, como o afeto, o amor, a cooperação, a mútua proteção e a sadia cumplicidade entre seus membros.

Relevante, pois, a reflexão no sentido de se perceber que os modelos legislados de uma sociedade em mutação devem estar atentos para a necessidade de

${ }^{63}$ HIRONAKA, Giselda Maria Fernandes Novaes. A incessante travessia dos tempos e a renovação dos paradigmas: a família, seu status e seu enquadramento na pós-modernidade. In. DIAS, Maria Berenice e BASTOS, Eliene Ferreira. Família além dos mitos. Ed. Del Rey, Belo Horizonte, 2008, pág. 63/64. 
acompanhar essas mudanças, sob pena de se tornarem anacrônicos e inúteis. Os códigos da pós-modernidade devem ser tais, portanto, que sejam não apenas abertos e permeáveis às novas visões, mas que sejam despojados de preconceitos e de ranços próprios do passado, para que se contenham regras e normas de efetiva eficácia e ajuste com o reclamo social atual.

Neste sentido, ensinam Cláudia Lima Marques, Maria Cláudia Cachapuz e Ana Paula da Silva Vitória: "as normas jurídicas são instrumentos que ajudam a determinar a realidade social, conforme os objetivos considerados justos e desejáveis para aquela sociedade. O direito pode ser, portanto, um instrumento de justiça e inclusão social, de proteção de determinados grupos e pessoas na sociedade, aí incluídos os filhos, a família monoparental, a família fora do casamento e outras novas uniões." 64

A família reencontrou-se no fundamento da afetividade, na comunhão do afeto, pouco importando o modelo que adote. A afetividade cuidada inicialmente por outras ciências deve ser estudada pelo Direito para orientar as relações familiares contemporâneas.

Assim, por intermédio da repersonalização das entidades familiares, Guilherme Calmon Nogueira da Gama propõe "preservar e desenvolver as qualidades mais relevantes entre os familiares: o afeto, a solidariedade, a união, o respeito, a confiança, o amor, o projeto de vida comum, permitindo o pleno desenvolvimento pessoal e social de cada partícipe, com base em ideais pluralistas, solidaristas, democráticos e humanistas. A família é valor constitucionalmente garantido nos limites de sua conformação e de não contraditoriedade aos valores que caracterizam as relações civis, especialmente a dignidade humana: ainda que diversas possam ser as suas modalidades de organização, ela é finalizada à educação e à promoção daqueles a que ela pertencem",65

Será com base no convívio e na solidariedade familiar e, especialmente nos laços de afeto desenvolvidos entre os integrantes que a família reconstituída encontrará a melhor forma de se estruturar e organizar. Mas, para que isto ocorra, importante o reconhecimento e o amparo pela sociedade e, consequentemente, pelas leis.

Registra Denise Duarte Bruno que, “a família, pensada enquanto união fundada no afeto, não naturalizada ou formalizada, organiza-se em torno de pelo menos

${ }^{64}$ MARQUES, Claudia Lima; CACHAPUZ, Maria Cláudia (col.) VITÓRIA, Ana Paula da Silva (col.). Igualdade entre Filhos no Direito Brasileiro Atual - Direito Pós-Moderno? Revista dos Tribunais, São Paulo, v. 764, 1999, pág. 14.

${ }^{65}$ GAMA, Guilherme Calmon Nogueira. Das relações de parentesco. In. Direito de Família e o Novo Código Civil (coord.) Rodrigo da Cunha Pereira e Maria Berenice Dias, Ed. Del Rey, belo Horizonte, 2001, pág. 88 
dois elementos vinculados ao componente religioso, presente em todas as sociedades: (1) a solidariedade e (2) a definição de papéis. Todas as religiões trazem em seu bojo preceitos quanto às formas de estabelecimento de relacionamento entre as pessoas, tais como: hierarquias, respeito, ajuda mútua etc. Estes preceitos, bem como a definição dos papéis de pai/mãe, determinam as diversas formas de organização familiar. E completa a autora: “Além disso, é a família que, através da reprodução de práticas de caráter místico e da realização de rituais para inserção de seus membros na comunidade religiosa, mantém e perpetua a religiosidade das sociedades." 66

Nestas circunstâncias, de extrema importância, a definição dos papéis dos integrantes do núcleo familiar (deveres/obrigações) em razão da multiplicidade de dinâmicas inter-relacionais.

No entanto a lei não confere direitos, mas deixa completamente alheios os pais afins, ao afirmar que os filhos serão criados sem qualquer intervenção do novo cônjuge ou companheiro. Essas ambiguidades, produto da omissão legal quanto ao lugar e às legitimidades dos integrantes dessas famílias provocam a fragilidade de suas funções tanto quando se atribui ao cônjuge o papel idêntico do genitor como quando não se lhe atribui papel algum.

Em outras áreas de conhecimento, que têm a família como objeto de pesquisa, a exemplo da sociologia, da psicanálise, a relação entre pais e filhos fundada na afetividade sempre foi determinante para sua identificação.

Rodrigo da Cunha Pereira explica que "para a Psicanálise, o que determina a constituição de uma família é sua estruturação psíquica. Isto é, importa saber se cada membro ocupa o seu lugar de filho, de pai ou de mãe. A não presença física do pai, ou a sua permanência não é definidora da situação, este pai ou esta mãe não precisam ser, necessariamente biológicos. Qualquer um pode ocupar esse lugar, desde que exerça tal função."67

É, então, a paternidade e a maternidade uma questão de função. Exemplo disso é a adoção. Registramos ainda, que, muitas vezes, nas famílias que adotam o modelo padrão, as funções de pai ou mãe não são exercidas pelos genitores biológicos, mas, por avós, tios, babás, vizinhos, amigos, em colaboração ou até mesmo em substituição aos pais.

${ }^{66}$ BRUNO, Denise Duarte. Família sócioafetiva. Revista Jurídica Del Rey, Belo Horizonte : Del Rey/IBDFAM, n. 8, p. 27, maio 2002. (Número especial).

${ }^{67}$ PEREIRA, Rodrigo da Cunha. Direito de Família: uma abordagem psicanalítica. Belo Horizonte, Del Rey, 1997, pág. 62. 
Para a formação de uma pessoa, o essencial é que alguém ocupe, em seu imaginário, o lugar simbólico de pai e de mãe. O relevante é a figura de um adulto como referência para a criança de pai e mãe, que, eventualmente, pode ser ocupado por terceiro, que exerça as funções inerentes ao papel de pai e mãe. O estabelecimento deste laço social viabilizará a formação e estruturação da criança enquanto sujeito, como adiante, em capítulo próprio, tal questão será estudada.

Assim, precisa a definição de João Batista Villela: "a família não é apenas o conjunto de pessoas onde uma dualidade de cônjuges ou de pai esteja configurado, senão também qualquer expressão grupal articulada por uma relação de descendência" ${ }^{\prime 68}$.

Assim, desbiologizar a paternidade e sair de seu campo meramente formal e jurídico abre a possibilidade de pensar a família em qualquer agrupamento humano, em qualquer ponto geográfico ou lugar da história, para poder retornar ao jurídico sob a clareza com que merece ser tratada a questão. Quando a norma torna-se norma, na verdade ela está dando legitimidade ao que já existe psiquicamente. ${ }^{69}$

Os pais afins têm um importante papel quando convivem com os filhos afins, no que cumpre no desenvolvimento da vida dos filhos, em um de seus aspectos mais importantes: o exercício da autoridade parental, objeto de estudo em capítulo próprio.

68 VILLELA, João Batista. As novas relações da família. Anais da XV Conferência Nacional da OAB em Foz do Iguaçu. São Paulo, JBA Comunicações, 1995, p. 642.

${ }^{69}$ PEREIRA, Rodrigo da Cunha. Direito de Família: uma abordagem psicanalítica. Belo Horizonte, Del Rey, 1997, pág. 13. 


\section{IV - PARENTESCO.}

No âmbito do Direito de Família, tradicionalmente, as relações jurídicas se classificam em relações conjugais, hoje incluídas as relações originadas da união estável; relações de parentesco e as relações de afinidade.

O parentesco se define no direito brasileiro como a relação que existe entre as pessoas que estão umas para com as outras na relação de ascendentes e descendentes ou, sem descenderem uma das outras provêm de um só tronco, ou ainda, resulte de outra origem.

O artigo 74 do Código Civil italiano estabelece o parentesco como vínculo entre as pessoas que descendem de um mesmo ascendente: "La parentela è el vincolo tra le persone che discendono da uno stesso stipite" ${ }^{, 70}$

As relações parentais revestem-se de grande importância na prática, na medida em que assinalam relevantes e constantes efeitos, estatuindo direitos e obrigações recíprocos entre os parentes, tanto na esfera pessoal como patrimonial, e fixando limites e proibições com fundamento em sua existência. Exemplos: impedimentos matrimoniais, legitimidade sucessória, dever de prestar alimentos. E não é só, o parentesco também determina o lugar das pessoas no contexto familiar, suas expectativas e compromissos.

Luiz Edson Fachin afirma que "as relações jurídicas entre pessoas consideradas pela lei como parentes, decorrem de laços, vínculos e efeitos apreendidos pelo próprio ordenamento legal. Supõem, assim, direitos subjetivos e deveres jurídicos recíprocos, decalcados da fonte normativa, em que se imponham por meio da jurisprudência, pela força criadora dos fatos. Tais direitos e deveres edificam feixe de vínculos jurídicos que se projetam para todo o ordenamento jurídico."71

Waldyr Grisard Filho assevera que as relações de parentesco são importantes nas definições dos membros do grupo familiar, uma vez que existe família quando entre determinados sujeitos há um vínculo de parentesco (consanguíneo, afetivo, adotivo) e lembrando que, a família contemporânea funda-se na idéia de afetividade, como sua função principal. $^{72}$

\footnotetext{
70 Tradução livre: O parentesco é o vínculo entre pessoas que descendem de uma mesma linha.

${ }^{71}$ FACHIN, Luiz Edson. Comentários ao Novo Código Civil. Do Direito de Família. Do direito pessoal. Das Relações de Parentesco. Arts. 1.591 a 1.638. Vol. XVIII - Coord. Sávio de Figueiredo Feitosa $-1^{\mathrm{a}}$ edição. Rio de Janeiro: Forense, 2003, pág. 03.

${ }^{72}$ GRISARD FILHO, Waldyr. Famílias reconstituídas. Novas uniões depois da separação. Ed. Revista dos Tribunais. São Paulo, 2007, pág. 31.
} 
No nosso sistema atual, o parentesco pode ser classificado em: a) consanguíneo, vinculando as pessoas que descendem uma das outras ou de um tronco que lhes é comum, limitado ao quarto grau; civil, por adoção, decorre da lei e nasce do laço convivencial válido e afinidade, que vincula o cônjuge aos parentes consanguíneos do outro cônjuge.

Esclarece-se que os esposos ou companheiros não podem considerar-se, em suas relações recíprocas, como parentes ou afins. Eles formam uma categoria à parte, determinando uma aliança, sem realizá-la juridicamente entre si, a qual os torna familiares. De uma maneira geral, pode-se dizer que parentesco é o vínculo jurídico que nasce dos laços de sangue, do casamento ou da união estável, da afinidade ou da adoção, constituindo as diversas classes de parentesco. Se desta última classe, diz-se sócio-afetiva, como proposta inovadora do art. 1.593, quando se refere ao parentesco que resulta 'de outra origem'. ${ }^{73}$

A divisão do parentesco em espécies tem importância não apenas para fins didáticos, mas também por distinguir as relações por origem, conteúdo e efeitos dentro do Direito de Família.

Para Rolf Madaleno, o parentesco distribui-se em classes, de acordo com os diversos aspectos de vinculação e se define como sendo o vínculo existente entre as pessoas em decorrência da consanguinidade, da afinidade e da adoção, devendo ser ressaltada a igualdade na filiação alcançada pela atual CF (art. 227, §6 $6^{\circ}$ ), desenhando, já sem tempo, um novo perfil no Direito de Família brasileiro, exatamente no encalço da tendência mundial de igualização da prole. ${ }^{74}$

\section{PARENTESCO NATURAL}

O parentesco por consanguinidade ou natural é a relação que vincula entre si as pessoas que descendem umas das outras ou de um tronco que lhes é comum. Assim, são parentes as pessoas que se ligam por um vínculo de sangue.

Quanto à antiga discriminação entre o parentesco matrimonial e extramatrimonial, lembra Luiz Edson Fachin, “dentre as várias espécies de parentesco, o denominado natural, ou consanguíneo, é aquele que retrata o vínculo entre pessoas que

${ }^{73}$ GRISARD FILHO, Waldyr. Famílias reconstituídas. Novas uniões depois da separação. Ed. Revista dos Tribunais. São Paulo, 2007, pág. 32.

${ }^{74}$ MADALENO, Rolf. Alimentos e sua restituição judicial, Revista Jurídica, Porto Alegre, no 211, p. 5, maio 1995. 
partilham de um mesmo tronco ancestral, ligadas, portanto, pelo sangue. Outrora, entretanto, a aplicação restrita deste conceito não bastava para caracterizá-la, pelo menos com seus efeitos jurídicos, posto que ao operador do direito se apresentava um exercício classificatório que deveria levá-lo à distinção entre relação de parentesco matrimonial e extramatrimonial. Tal classificação era levada a efeito devido à acepção normativista acerca do Direito, que aplicada ao Direito de Família tornava impossível se atribuir efeitos no ordenamento jurídico às relações familiares de fato, isto é, que não estavam inscritas precisamente nos moldes legais". ${ }^{75}$

Entre os diversos critérios de classificação e de contagem do parentesco, adota-se a linha como sendo a vinculação da pessoa a tronco ancestral comum. Tal critério leva em consideração a relação de ascendência e descendência entre os parentes - parentes em linha reta -, ou a relação de parentesco fundada na ancestralidade comum, sem relação de ascendência e descendência entre os parentes em questão - parentes em linha colateral.

No âmbito das relações de parentesco natural ou consanguíneo, o vínculo ao tronco ancestral comum denomina-se linha, que, pode ser dividida em linha reta e linha colateral, conforme se refira a pessoas que tenham relação de descendência e ascendência entre si, ou diga respeito a pessoas que embora não possuam relação de ascendência ou descendência tenham o mesmo tronco ancestral.

$\mathrm{Na}$ linha reta as pessoas descendem direta e sucessivamente umas das outras, como bisavô, avô, pai, filho, neto, bisneto, estabelecendo, assim, uma série infinita. Nesta linha de parentesco, a característica é a inexistência de limite de graus entre aqueles que mantém relação de ascendência e descendência. Parentes ascendentes são o pai, o avô, o bisavô, o trisavô, o tetravô e assim por diante, e os descendentes são o filho, neto, bisneto, e assim sucessivamente. Nesta linha de parentesco distingue-se o parentesco ascendente do parentesco descendente, conforme se sobe ou se desce em direção àquela pessoa que de quem ou que dele proveio. Diferencia-se também a linha materna da paterna, dependendo do marco referencial ser a mãe ou o pai.

A linha reta é mensurada em grau, sendo que cada um destes corresponde a uma geração, de maneira tal que o filho e o pai são parentes em primeiro grau, o avô e o neto são parentes em segundo grau, e assim sucessivamente já que, como mencionado, para o direito a relevância desse tipo de parentesco é ad infinitum.

\footnotetext{
${ }^{75}$ FACHIN, Luiz Edson. Comentários ao Novo Código Civil. Do Direito de Família. Do direito pessoal. Das Relações de Parentesco. Arts. 1.591 a 1.638. Vol. XVIII - Coord. Sávio de Figueiredo Feitosa -1 ${ }^{a}$ edição. Rio de Janeiro: Forense, 2003, pág. 18.
} 
$\mathrm{Na}$ linha colateral ou transversal as pessoas provém de um tronco comum sem descenderem diretamente umas das outras. São as relações que se estabelecem entre irmãos, tios e sobrinhos. Nesta linha o parentesco pode ser bilateral ou unilateral, dependendo se o parentesco for estabelecido pela linha materna e paterna ou apenas por uma delas, o que se verifica, especialmente no caso de irmãos. A colateralidade ainda pode ser igual ou desigual, em razão da distância apresentada entre o ascendente comum. No caso de irmãos, por exemplo, a distância é igual.

Diferentemente do parentesco em linha reta, no parentesco colateral há limitação, nos termos do artigo 1.592 do Código Civil: "São parentes em linha colateral ou transversal até o quarto grau, as pessoas provenientes de um só tronco, sem descenderem umas das outras".

Mas, esta relação se modificou ao longo dos anos, de acordo com a conveniência da sociedade. No Código Civil de 1916, por exemplo, estabelecia o artigo 331 que o parentesco na linha colateral se dava até o sexto grau.

Sobre o tema, lembra Waldyr Grisard Filho: "desde a família arcaica até a família pós-moderna, o parentesco revela-se como um fato social fundado em certas necessidades, cambiantes, da sociedade. Quando se modificam as necessidades de uma determinada cultura, elevando-se continuamente de um nível inferior para outro mais superior, modifica-se o sistema de parentesco; não só, também o casamento e a vida doméstica. Demonstram os sociólogos e os antropólogos que nas famílias primitivas nem sempre o parentesco está relacionado com o vínculo biológico, uma vez admitida a promiscuidade sexual neste período. Tenha-se como exemplo a família punaluana, cuja essência repousa sobre a noção de casamento grupal, de sorte que muitos homens podiam ser pais de uma criança, o que transferia aos irmãos da mãe as funções paternas (relações avunculares); pai só é necessário para o ato da procriação. Diferentemente, domina na sociedade atual o sistema unitário da família nuclear pai-mãe-filho. Neste modelo, pai-mãe e filho são parentes consanguíneos, porque se vinculam geneticamente.”76

A linha colateral, diferente da linha reta, não possui relevância ad infinitum para o nosso Direito, motivo da limitação do parentesco ao quarto grau, pois entende-se que parentesco mais longínquo desconfiguraria o afeto e a solidariedade que sustentam as relações de direito familiares

\footnotetext{
${ }^{76}$ GRISARD FILHO, Waldyr. Famílias Reconstituídas. Ed. RT, 2007, pág. 117/1178.
} 
O grau de parentesco é outra forma de classificação dos parentes, que auxilia a localização do indivíduo dentro da família, em harmonia com a divisão entre as linhas reta e colateral.

A relevância desses graus para o Direito varia conforme a situação em questão, seja para efeitos sucessórios, impedimentos matrimoniais, depor como testemunha ou, ainda, para o dever de alimentos.

Arnoldo Wald diz que "Os graus representam o número de gerações existentes entre as partes interessadas.",77

A contagem dos graus de parentesco na linha reta é feita observando-se o número de gerações existentes entre os parentes. Assim, pai e filho são parentes em primeiro grau, avô e neto são parentes em segundo grau, bisneto e bisavô são parentes em terceiro grau, e assim, sucessivamente. Ou seja, conta-se o grau de parentesco em atenção ao número de gerações existentes entre os dois parentes.

Ensina Guilherme Calmon Nogueira da Gama que, na linha colateral, o parentesco é contado entre os parentes, com a nuance de procurarmos o ascendente comum e calcularmos a distância entre as gerações até este, para depois descermos até o outro com quem se pretende estabelecer o grau de parentesco ${ }^{78}$. Assim, dois irmãos são parentes em segundo grau na linha colateral, um tio e um sobrinho, por sua vez são parentes em terceiro grau e primos filhos de dois irmãos são parentes em quarto grau.

\section{PARENTESCO CIVIL}

Dentre as espécies de parentesco, há o denominado civil, que decorre da adoção, uma vez que a lei atribui o estatuto de relação de parentesco ao vínculo existente entre adotante e adotado. O parentesco é estabelecido judicialmente, independente, pois, de laços de sangue. Cria-se uma relação entre pais e filhos através de um ato judicial complexo, pelo qual se faz um filho biologicamente de outrem um filho próprio, pressupondo uma realidade afetiva. A adoção atribui a condição de filho ao adotado, que se desliga de qualquer vínculo com seus parentes consanguíneos. O parentesco se estende aos parentes do adotante e do adotado.

\footnotetext{
${ }^{77}$ WALD, Arnoldo. O novo direito de família. Ed. Saraiva, 2002, pág. 37.

${ }^{78}$ GAMA, Guilherme Calmon Nogueira. Das relações de parentesco. In, DIAS, Maria Berenice; PEREIRA, Rodrigo da Cunha. Direito de Família e o novo código Civil, Belo Horizonte. Del Rey, 2001, p. 93
} 
De todo modo, o vínculo criado estipula a condição de filho adotado, desligando-o de vínculos com seus pais e parentes consangüíneos, exceto no tocante aos impedimentos matrimoniais.

\section{AFINIDADE}

O parentesco por afinidade, por sua vez, decorre da lei e nasce do laço convivencial válido e se estabelece na linha reta, com os ascendentes e descentes do cônjuge e, na linha colateral, se limita aos irmãos do cônjuge, nos termos do artigo 1.595, $\S 1^{\circ}$ do Código Civil de 2002. Findo o vínculo extingue-se o parentesco, exceto na linha reta. Entretanto cumpre esclarecer que, na hipótese de um novo casamento, o novo cônjuge não manterá relação alguma com os parentes afins de seu ex-cônjuge.

Afinidade é o nome que se dá à relação de parentesco que vincula o cônjuge aos parentes consanguíneos do outro, por determinação legal, desde que decorra da união estável ou matrimônio válido. A mensuração da proximidade desse vínculo se dá à semelhança da utilizada nas relações de parentesco naturais, utilizando o grau como medida correspondente a uma geração. Destaca-se que a afinidade é um vínculo pessoal, donde se extrai que não há relação de afinidade entre os parentes dos cônjuges ou companheiros, o mesmo ocorrendo diante de um novo matrimônio, posto que os afins do primeiro não serão afins do cônjuge das segundas núpcias. ${ }^{79}$

O vínculo de afinidade em linha reta pode decorrer de três situações distintas: a) do casamento contraído pela própria pessoa, gerando afinidade entre ela e os ascendentes e descendentes de seu cônjuge; b) do casamento contraído pelo descendente da pessoa, criando o vínculo de afinidade entre a pessoa e o cônjuge do descendente; c) do casamento contraído pelo ascendente da pessoa, constituindo o vínculo entre a pessoa e o cônjuge de seu ascendente. ${ }^{80}$

Importante, no entanto, ressaltar que diferentemente do parentesco consanguíneo e civil, o parentesco por afinidade não gera direitos e deveres - os afins não têm direito a sucessão, por exemplo.

\footnotetext{
${ }^{79}$ FACHIN, Luiz Edson. Comentários ao Novo Código Civil. Do Direito de Família. Do direito pessoal. Das Relações de Parentesco. Arts. 1.591 a 1.638. Vol. XVIII - Coord. Sávio de Figueiredo Feitosa - $1^{\text {a }}$ edição. Rio de Janeiro: Forense, 2003, pág. 38.

${ }^{80}$ GAMA, Guilherme Calmon Nogueira. Das relações de parentesco. In, DIAS, Maria Berenice; PEREIRA, Rodrigo da Cunha. Direito de Família e o novo código Civil, Belo Horizonte. Del Rey, 2001, p. 101.
} 
Neste sentido registra Luiz Edson Fachin: “a noção de parentesco por afinidade, encartada no art. 1595, onde se apresenta, com efeito, em variados campos de ordem jurídica, como sabido: sem embargo, há realmente limites como na hipótese da pensão alimentar, o que já restou fixado pela jurisprudência, pois "não há extensão legal à obrigação de alimentos à nora pelo sogro ou sogra, ou ambos. Nora está no campo do parentesco por afinidade estabelecida pelo casamento. Embora a afinidade não se dissolva pela morte do cônjuge, ela não minucia, no ordenamento legislativo atual e específico, direito à pretensão de alimentos aos sogros, pelo que há de se reconhecer a ilegitimidade ad causam destes, na ação proposta pela nora." 81

A contagem de graus de parentesco nas relações denominadas afins, se dá na mesma forma que nas relações de parentesco consanguíneo, lembrando que este parentesco limita-se aos ascendentes, descendentes, onde a contagem se faz por geração - , cada geração equivale a um grau; e na linha colateral, o parentesco não passa do segundo grau, posto que restringe-se aos irmãos do cônjuge ou companheiro somente em relação ao outro cônjuge.

O legislador de 2002 ampliou o vínculo do parentesco, posto que abranje o parentesco por vínculo de afinidade, conforme nomenclatura do artigo 1.595 do Código Civil, que trata do vínculo com a família do cônjuge como parentesco por afinidade.

E, por ser a afinidade um vínculo estritamente pessoal, não há vínculo entre concunhados, vez que os afins de um cônjuge não são afins entre si. Pelo mesmo motivo, os afins do primeiro casamento não mantêm qualquer vínculo com o cônjuge do segundo casamento.

Porém, adverte Guilherme Calmon Nogueira da Gama ${ }^{82}$, que "parentesco e afinidade são vínculos que não se confundem, a despeito de ser utilizada terminologia que muitas vezes os considera no mesmo contexto, com a expressão 'parentesco por afinidade'. Aliás, os dois textos - o do Código Civil de 1916 e o do novo Código Civil não se preocuparam em distinguir as noções de parentesco e afinidade, o que fica evidenciado pela própria ementa do Título V, do Livro de Direito de Família do Código Civil de 1916 e do Subtítulo II, do Título I, do novo Código Civil - Projeto de Lei no 118/84: Das Relações de Parentesco. Na tramitação do Projeto do novo Código no Senado

\footnotetext{
${ }^{81}$ FACHIN, Luiz Edson. Comentários ao Novo Código Civil. Do Direito de Família. Do direito pessoal. Das Relações de Parentesco. Arts. 1.591 a 1.638. Vol. XVIII - Coord. Sávio de Figueiredo Feitosa $-1^{a}$ edição. Rio de Janeiro: Forense, 2003, pág. 37.

82 GAMA, Guilherme Calmon Nogueira. Das relações de parentesco. In, DIAS, Maria Berenice; PEREIRA, Rodrigo da Cunha. Direito de Família e o novo código Civil, Belo Horizonte. Del Rey, 2001, p. 87/88.
} 
Federal, foi apresentada emenda de n. 221, com a finalidade de acrescentar à designação do subtítulo a expressão "e da afinidade". Contudo, tal emenda foi rejeitada sob a justificativa do relator Josaphat Marinho de que "não há dúvida, pois, de que o vocábulo 'parentesco' abrange a 'afinidade' sendo desnecessário modificar a designação do Subtítulo'. A despeito de não haver qualquer vício constitucional na emenda do subtítulo do projeto, tal como anteriormente anunciado, é de se lamentar que o legislador não tenha adotado técnica jurídica mais consetânea com as importantes e fundamentais diferenças entre parentesco e afinidade".

No mesmo sentido é a lição de Arnoldo Wald ${ }^{83}$ "a afinidade não é parentesco, consistindo na relação existente entre um dos cônjuges e os parentes do outro. É um vínculo que não tem a mesma intensidade que o parentesco e se estabelece entre sogro e genro, cunhados, etc".

Sobre o assunto, anota Luiz Edson Fachin que "o termo parentesco, entretanto, liga-se mais intimamente à realidade que informa o vínculo entre pessoas que possuem um mesmo ancestral, ao passo que a relação travada entre um cônjuge e os parentes do outro denomina-se afinidade. ${ }^{84}$

Contudo, o legislador de 2002, ao determinar a aliança que se estabelece entre cada cônjuge e os parentes do outro chamando de "parentes" os "afins" (artigo 1.595, $\S 1^{\circ}$ ) pareceu por abranger à noção do parentesco, o vínculo da afinidade, sem considerar as diferenças existentes entre estes dois institutos, trazendo especialmente a idéia que o parentesco decorre do laço convivencial válido. Da mesma forma, nos artigos $1.524 \mathrm{e}$ 1.737 do Código Civil ao tratar das causas suspensivas do casamento e da tutela, respectivamente, o legislador chama de parentes os afins.

Neste contexto, Waldyr Grisard Filho afirma, "portanto, não é o vínculo de sangue que estabelece este parentesco, mas a união conjugal ou estável, determinando que genro e nora e sogro e sogra, reciprocamente, vinculem-se no mesmo grau que filho e filha e pai e mãe, isto é, em primeiro grau por afinidade. Da mesma maneira, quando um dos cônjuges ou companheiro tem filhos de uma união precedente, gera o parentesco por afinidade em primeiro grau entre estes e o novo cônjuge ou companheiro do genitor". 85

\footnotetext{
${ }^{83}$ WALD, Arnoldo. Curso de Direito Civil brasileiro: o novo direito de família. São Paulo, Ed. Saraiva, 2002, pág.. 36

${ }^{84}$ FACHIN, Luiz Edson. Comentários ao Novo Código Civil. Do Direito de Família. Do direito pessoal. Das Relações de Parentesco. Arts. 1.591 a 1.638. Vol. XVIII - Coord. Sávio de Figueiredo Feitosa $-1^{\mathrm{a}}$ edição. Rio de Janeiro: Forense, 2003, pág. 18.

${ }^{85}$ GRISARD FILHO, Waldyr. Famílias reconstituídas. Novas uniões depois da separação. Ed. Revista dos Tribunais. São Paulo, 2007, pág. 118.
} 
Neste raciocínio, entre os filhos do cônjuge e seu novo parceiro se estabelece uma relação de parentesco por afinidade, nestes casos, o vínculo familiar existe por força da lei, ainda que reafirmado por laços psicológicos construídos pelo afeto.

Todavia entre os filhos advindos de relacionamentos anteriores dos cônjuges que forma uma família reconstituída não há qualquer vínculo de parentesco. Contudo são geralmente chamados de irmãos, simbolizando a existência de um laço afetivo entre eles, na medida que vivem no mesmo lar e são partes de uma família. Como se pode observar, as relações entre os componentes de um grupo familiar são muito mais pautadas pelo afeto que pelos nexos ditados pela lei.

Nos sistemas, em geral, não existe parentesco entre os parentes consanguíneos de um cônjuge ou companheiro com os do outro. Não há pela afinidade um parentesco entre os pais e irmãos de um cônjuge e os filhos próprios do outro. Esta noção estreita de parentesco, atualmente, não se pode sustentar, cedendo a um conteúdo sócioafetivo, que amplifica a noção de família, aí incluídos os avós, tios, primos afins.

Por tal razão, embora não se atribua à afinidade a qualidade de parentesco - o que tão somente denominaria indivíduos membros de uma família - esta noção não se sobrepõe ao conteúdo sócio-afetivo das relações familiares estabelecidas entre os membros da família reconstituída, pelo que, ao parentesco entre um dos cônjuges ou companheiros e os filhos do outro dedica-se um vínculo familiar pleno, pois tão natural quanto o vínculo sanguíneo, vez que decorrente do afeto e os estados psíquicos daí derivados.

\section{PARENTESCO POR AFETIVIDADE}

Já alertava o professor João Batista Villela, "se se prestar atenta escuta às pulsações mais profundas da longa tradição cultural da humanidade, não será difícil identificar uma persistente intuição que associa a paternidade antes com o serviço que com a procriação. Ou seja: ser pai ou ser mãe não está tanto no fato de gerar quanto na circunstância de amar e servir." 86

Para a legitimação das relações entre os membros da família reconstituída, muito mais importante a noção do parentesco estabelecido em razão do

${ }^{86}$ VILLELA. João Baptista. Desbiologização da Paternidade. Revista Forense, jul-ago-set 1980, p. 47. 
afeto, capaz de estabelecer vínculos e gerar direitos e obrigações, como adiante se demonstrará.

A alteração da concepção jurídica de família conduz necessariamente à mudança dos vínculos estabelecidos entre os integrantes do grupo. Deve-se buscar, portanto, um conceito plural de paternidade, maternidade, fraternidade e, consequentemente, de parentesco, no qual a vontade, o consentimento, a afeição, a responsabilidade servirão de base para o seu estabelecimento.

Neste sentido a lição de Guilherme Calmon Nogueira da Gama: "a natureza jurídica da paternidade, maternidade e filiação nos dias atuais não decorre exclusivamente de informações biológicas ou genéticas, havendo exemplos claros no Direito Comparado em que se dá relevo a sentimentos nobres, como o amor, o desejo de construir uma relação afetuosa, carinhosa, reunindo as pessoas num grupo de companheirismo, lugar de afetividade, para o fim de estabelecer relações de parentesco. A disciplina jurídica das relações de parentesco entre pais e filhos não atende, exclusivamente, quer valores biológicos, quer juízos sociológicos; é uma moldura a ser preenchida, não com meros conceitos jurídicos ou abstrações, mas com vida, na qual pessoas espelham sentimentos".. 87

O artigo 1.593 do Código Civil, em sua parte final dispõe que o parentesco pode decorrer de "outras origens", abrindo espaço para o reconhecimento de novas formulações e classes de parentesco, especialmente da classe sócio-afetiva.

O parentesco contém elementos biológicos, afetivos e jurídicos, enquanto vínculo de união das pessoas de uma família. E, como veremos, a formação deste vínculo não é exclusivamente fruto da consanguinidade ou de atribuição pelo estatuto legal embora a lei deva amparar os vínculos estabelecidos por outros meios -, mas também estabelece-se pelo afeto.

$\mathrm{Na}$ busca da origem do parentesco, Rolf Madaleno ${ }^{88}$ nos ensina que: “o parentesco não é somente um fato da natureza, e sim uma noção social que varia de cultura para cultura e, em verdade qualquer adulto pode se converter em um pai psicológico, dependendo da qualidade da interação diária, porquanto o verdadeiro pai é aquele que efetivamente se ocupa da função parental".

\footnotetext{
${ }^{87}$ GAMA, Guilherme Calmon Nogueira. Das relações de parentesco. In, DIAS, Maria Berenice; PEREIRA, Rodrigo da Cunha. Direito de Família e o novo código Civil, Belo Horizonte. Del Rey, 2001, p. 97.

${ }^{88}$ MADALENO, Rolf. Direito de família em pauta. Porto Alegre, Livraria do Advogado, 2004.
} 
Sem precedente na legislação anterior, dispõe o artigo 1.593 do Código Civil de 2002 que "o parentesco é natural ou civil, conforme resulte da consangüinidade ou outra origem".

Ao se referir ao parentesco natural, estaria o legislador referindo-se ao parentesco resultante da consanguinidade e ao se referir ao parentesco civil, referia-se ao parentesco resultante de outra origem, como uma variante do parentesco civil, Abrindo, assim, espaço para o reconhecimento do parentesco por afetividade, como parentesco resultante de outra origem.

Endossando a idéia do parentesco por afetividade contida na parte final do artigo 1.593 do Código Civil, Waldyr Grisard Filho ${ }^{89}$, pondera: "o dispositivo tem sua força inovadora em sua parte final "ou outra origem", que inaugura no direito brasileiro uma nova classe de parentesco, nem natural, nem civil, fundada em vínculos sócioafetivos, potencializados à produção de efeitos jurídicos, pessoais e patrimoniais".

No mesmo sentido é a lição de Luiz Edson Fachin: "O novo Código Civil brasileiro encarta regra inexistente no Código de 1916, tratando agora das fontes do parentesco natural, civil, consangüíneo ou de outra origem. O teor desse novo dispositivo consagra situações jurídicas conhecidas e também abre espaço para novas formulações já em construção, especialmente a socioafetividade cabível na 'outra origem'."90

Nesta classe incluem-se, também, as relações de parentesco oriundas das inseminações artificiais heterólogas, do reconhecimento voluntário, da adoção à brasileira, da própria adoção judicial, dos filhos de criação, de todos aqueles que caibam na noção de posse de estado de filho.

A Constituição Federal valorizou a família e a pessoa humana, elevando a cidadania e a dignidade da pessoa humana a fundamento do próprio Estado, privilegiando não os interesses da família, mas o bem-estar de seus membros.

A sociedade contemporânea caracteriza-se por apresentar uma estrutura complexa do parentesco, fundada no princípio da liberdade de eleição do cônjuge ou companheiro, embora esta liberdade ainda encontre um reduzido número de prescrições negativas.

${ }^{89}$ GRISARD FILHO, Waldyr. Famílias Reconstituídas: novas uniões depois da separação. Editora RT, 2007. pág. 30/36.

${ }^{90}$ FACHIN, Luiz Edson. Comentários ao Novo Código Civil. Do Direito de Família. Do direito pessoal. Das Relações de Parentesco. Arts. 1.591 a 1.638. Vol. XVIII - Coord. Sávio de Figueiredo Feitosa -1 ${ }^{a}$ edição. Rio de Janeiro: Forense, 2003, pág. 17. 
O princípio da afetividade encontra-se sedimentado no campo jurídicoconstitucional em vários momentos significativos: artigos $226, \S \S 4^{\circ}$ e $7^{\circ}, 227, \S \S 5^{\circ}$ e $6^{\circ}$ da Constituição Federal.

A verdade socioafetiva nas relações paterno-filiais é hoje uma realidade e, de forma acertada, vem sendo reconhecida pelos Tribunais brasileiros.

Como disse Rolf Madaleno: “A própria modificação na concepção jurídica de família conduz, necessariamente, a uma alteração na ordem jurídica da filiação, em que a paternidade socioafetiva deverá ocupar posição de destaque, sobretudo para solução de conflitos de paternidade". ${ }^{91}$

De fato, é de extrema relevância o reconhecimento das relações de parentesco decorrentes do afeto. Com as relações conjugais, estabelecidas entre os cônjuges com o casamento, estabelecem-se as relações de parentesco entre as pessoas pertencentes ao mesmo tronco familiar, entre aquelas que guardam relações de ascendência e descendência uma com as outras, estabelece-se ainda, relação de afinidade entre o cônjuge e os parentes do outro. Tais formas de parentesco, contudo, não exaurem e não refletem as relações existentes na sociedade, pois seria deixado de lado situações de fato, constatadas de forma expressiva, como as relações de parentesco socioafetivas. São elas comuns no Brasil, e inscrevem-se na realidade segundo a qual uma pessoa é acolhida no âmbito familiar, sendo neste criada e educada, tal como se da família fosse. Recepcionando a tese do parentesco socioafetivo, o Código Civil de 2002, abre as portas para outras origens parentais.

Não temos dúvidas que o legislador tenha reconhecido no artigo 1593 , outras espécies de parentesco civil além daquele decorrente da adoção, acolhendo, efetivamente o parentesco por afetividade, e, consequentemente, como adiante estudaremos, a paternidade socioafetiva.

Se pararmos para pensar e nos perguntarmos: a família se manteria se não existisse o afeto que une os seus membros? Acreditamos ser a resposta negativa, e esta é a razão da relevância do aspecto afetivo na caracterização e regulamentação das relações familiares e no estabelecimento do vínculo entre os integrantes do grupo familiar.

Não há dúvida quanto ao valor jurídico do afeto, apto a fundar relação familiar com assento constitucional. A Constituição de 1988, reconhecendo as alterações ocorridas na sociedade, estabeleceu princípios norteadores das relações familiares que

\footnotetext{
${ }^{91}$ MADALENO, Rolf. Novas perspectivas no Direito de Família. Ed. Livraria do Advogado, Porto Alegre, 2000, pág. 40.
} 
alteraram profundamente sua estrutura, entre os quais adotou o princípio do melhor interesse do menor, o que, possibilita o reconhecimento de relações familiares baseadas no afeto.

O artigo 1.593 do Código Civil de 2002, nestas circunstâncias, consagra novas formulações familiares, especialmente a socioafetiva, tão civil como o vínculo estabelecido pela adoção ou pela inseminação artificial heteróloga. Observe-se que, em todas estas hipóteses, prevalece a parentalidade afetiva sobre a identidade genética. E não podia ser diferente, sob pena de descumprimento dos preceitos constitucionais como o da igualdade, da dignidade da pessoa humana, e o do melhor interesse do menor.

Lembra Luiz Edson Fachin, "a avançada doutrina familiarista, antecipando-se às possibilidades que a hermenêutica pode abrir à luz do art. 1.593, já ressaltava, quanto às espécies de parentesco, (...) grandes transformações por que passam as relações que abriram caminho para uma nova forma de parentesco, o parentesco voluntário, que tanto se origina nas formas científicas e médicas de procriação, como das relações vividas no grupo familiar, muitas vezes composto por pessoas que levam para casa os filhos havidos de casamentos anteriores, somados aos nascidos da relação atual, biológicos, in vitro ou adotivos." 92

O estabelecimento das relações de parentesco pela afetividade permite, especialmente, a concretização do vínculo estabelecido entre o cônjuge e os filhos exclusivos de seu companheiro, situação, como vista, bastante comum em nossa sociedade. Registra Giselda Maria Fernandes Novaes Hironaka, sob a visão contemporânea do artigo 1.593 do Código Civil de 2002 “o que merece ser ressaltado, enfim, é o afeto sincero destes homens pelos filhos de suas mulheres, independentemente de estarem a eles ligados por qualquer liame de parentesco ou de saberem que, alia, a descendência se identifica apenas pela linha feminina." 93

Anota Antônio Mathias Coltro, quanto às relações baseadas no afeto, que "variadas são as acepções do fato, eis que pode ser “(...) sinônimo de amizade, simpatia, amor, paixão, emoção ou inclinação, entre outras palavras que expressam sentimentos (..)”. Largo é, pois, o campo dessa compreensão “ (...) uma vez que tanto a intenção de constituir família quanto a convivência duradoura e o respeito e considerações

\footnotetext{
${ }^{92}$ FACHIN, Luiz Edson. Comentários ao Novo Código Civil. Do Direito de Família. Do direito pessoal. Das Relações de Parentesco. Arts. 1.591 a 1.638. Vol. XVIII - Coord. Sávio de Figueiredo Feitosa -1ª edição. Rio de Janeiro: Forense, 2003, pág. 27.

${ }^{93}$ HIRONAKA, Giselda Maria Fernandes. Família e casamento em evolução. Revista Brasileira de Direito de Família, Porto Alegre, a.1, nº 1, p. 10, abr/mai 1999.
} 
mútuos (além da assistência moral e material recíproca e também a guarda, sustento e educação dos filhos comuns) têm como ínsitos à moldura e conteúdo de cada um a manifestação do afeto (...)." Com efeito, amplo é o horizonte de possibilidades que aí se abre."94

O que se coloca em cena não é precisamente a linhagem; apresenta-se, isso sim, uma nova base de vínculo parental, que permitirá, especialmente, o amparo de relações estabelecidas entre pais e filhos, com base exclusivamente no afeto. É o que se procurará demonstrar no capítulo a seguir.

${ }^{94}$ COLTRO, Antônio Mathias. Um valor imprescindível. Del Rey. Revista Jurídica, Belo Horizonte, a. 4, ${ }^{\circ}$ 8 , pág. 16, maio 2002. 


\section{V - PATERNIDADE, FILIAÇÃO E AFETO.}

\section{1- A AFETIVIDADE COMO VALOR JURÍDICO.}

A Constituição brasileira de 1988, com precisão, à época de sua aprovação, enfrentou problemas extremamente controvertidos, mas, acertadamente, disse que a família, existente na realidade brasileira, não era mais exclusivamente a família matrimonial.

A família, como visto, perdeu historicamente as suas funções tradicionais: de procriação, econômica, religiosa e política. $\mathrm{O}$ exemplo marcante na história brasileira até o advento do século XX é o da família rural, em que o senhor de engenho era ao mesmo tempo um chefe econômico, um chefe religioso e um chefe político. Enquanto a família desempenhava essas funções, algo que sempre esteve subjacente à família nunca vinha à tona, nem era levado em conta pelo Direito, que era a afetividade.

Porém, a família, como grupo social que é, não permaneceu estática, sentiu e fez sentir transformações sociais. Contudo, apenas no século XX, vem ocorrer a vitória da modernidade na relação de família, o que se traduziu na vitória da racionalidade igualitária e libertária sobre a autoridade.

Com o processo de urbanização, costumes foram sendo modificados, a grande prole deu lugar a um número cada vez mais reduzido de filhos. Por outro lado, com um número menor de filhos, houve a possibilidade de maior convívio entre estes e os pais, dando margem a um relacionamento mais próximo, pautado na preocupação de um membro da família com os demais, permitindo a abertura de espaço para o afeto, bem como indicando o início de modificação no modelo tradicional.

Desta forma, a redução da estrutura familiar acabou contribuindo para que ela pudesse se tornar uma comunidade mais coesa, com maior proximidade entre seus membros. As atividades desenvolvidas fora de casa aumentaram. Em consequência, a família deixou de ser uma unidade de produção e passou a ser o 'lócus' de convivência. Assim, como afirma Antunes Varela: "a família converteu-se apenas, ao fim de cada semana, num lugar de refúgio da intimidade das pessoas contra a massificação da 
sociedade de consumo. Ela constitui hoje um centro de restauração semanal da personalidade do indivíduo contra o anonimato da rua." $" 95$

Hoje, segundo a historiadora Michelle Perrot, a família se abre para configurar-se, "num mundo duro, um abrigo, uma proteção, um pouco de calor humano", lar onde se sobressaem a solidariedade, a fraternidade, a ajuda mútua, os laços de afeto e o amor". 96

Dentre as inúmeras transformações sociais que aconteceram, especialmente no século passado, podem ser destacadas, além do processo de urbanização, a industrialização ocorrida no país; o ingresso da mulher no mercado de trabalho, o aumento em sua esfera de atuação social, política e jurídica; a transformação da condição social do jovem. Com a maior mobilidade no desempenho dos papéis que passaram a ser estabelecidos em função das aptidões de seus membros, a família gradativamente passou a refletir mais o interesse daqueles do que desta.

Lembra Luiz Edson Fachin, que "distante daquela conformação antiga, como sintetizam os profs. José Lamartine Correa de Oliveira e Francisco José Ferreira Muniz, a família "transforma-se no sentido de que se acentuam as relações de sentimentos entre os membros do grupo: valorizam-se as funções afetivas da família que se torna o refúgio privilegiado das pessoas contra a agitação da vida nas grandes cidades e das pressões econômicas e sociais". ${ }^{97}$

Tomam vulto as relações de afeto, de solidariedade e de cooperação, na concepção eudemonista da família: não é mais o indivíduo que existe para a família e para o casamento, mas a família e o casamento que existem para o seu desenvolvimento pessoal, em busca de sua aspiração à felicidade. Esta, reconhecida como a "doutrina que admite ser a felicidade individual ou coletiva o fundamento da conduta humana moral". ${ }^{98}$

A família reencontrou-se no fundamento da afetividade, na comunhão de afeto, pouco importando o modelo que adote, inclusive, o que se constitui entre um pai ou uma mãe e seu filho.

Para Maria Berenice Dias e Rodrigo da Cunha Pereira, "as transformações da sociedade estão associadas a um novo discurso sobre a sexualidade, cuja

\footnotetext{
${ }^{95}$ VARELA, Antunes. Direito da Família. 3. Ed. Lisboa, Petrony, 1993, pág. 48.

${ }^{96}$ PERROT, Michelle. O Nó e o ninho, in Reflexões para o futuro. São Paulo, Ed. Abril, 1993, p. 81

${ }^{97}$ FACHIN, Luiz Edson. A tríplice paternidade dos filhos imaginários. ALVIM, Teresa Arruda (coord.). Repertório de Jurisprudência e Doutrina sobre Direito de Família: Aspectos constitucionais, civis e processuais. São Paulo. Revista dos Tribunais, 1998, v. 02, pág. 174..

${ }^{98}$ HOLANDA, Aurélio Buarque. Novo dicionário da língua portuguesa - $2^{\mathrm{a}}$ edição - Ed. Nova Fronteira, Rio de janeiro, p. 734.
} 
base foi assentada pela Psicanálise, ensejando constatar que a sexualidade se insere antes na ordem do desejo, que na da genitalidade, como sempre fora tratada pelo Direito. Ante essa mudança, o pensamento contemporâneo ampliou seu horizonte sobre as diversas formas de manifestação da afetividade compreendendo as várias possibilidades de constituir-se uma família. Principia, aí, a liberdade do afeto. Ou seja, a possibilidade de não se sujeitar aos modelos herdados e ainda postos como lei. Ganha curso histórico a libertação dos sujeitos." 99

As pessoas, que antes procuravam se enquadrar nos modelos préestabelecidos de configuração familiar, para não ficarem alheios à sociedade - a formação de famílias fora dos padrões se dava à margem do ordenamento jurídico -, mudado foco, e enaltecido o afeto, tiveram maior liberdade para se unir e estruturar a sua família, sem se sentirem discriminadas.

Neste sentido, explica Silvana Maria Carbonera que: "se a formação de famílias já se dava à margem da esfera jurídica, a preocupação com os sujeitos sobrepunha-se àquela relativa à adequação ao modelo legal. Ganhou dimensões significativas um elemento que anteriormente estava à sombra: o sentimento. E, com ele, a noção de afeto, tomada como um elemento propulsor da relação familiar, revelador do desejo de estar junto a outra pessoa ou pessoas, se fez presente". 100

A restauração da primazia da pessoa humana, nas relações civis, é condição de adequação do direito à realidade social e aos fundamentos constitucionais. Os laços de afeto e de solidariedade derivam da convivência familiar e não do sangue.

Já questionava o professor Eduardo de Oliveira Leite ${ }^{101}$, sobre a "verdade absoluta" da filiação biológica: "as indagações doutrinárias mais recentes têm insistido de forma cada vez mais freqüente e firme, que a filiação não é somente fundada sobre os laços de sangue; o vínculo sanguíneo determina, para a grande maioria dos pais, um laço fundado sobre a vontade de aceitação dos filhos. Logo, a vontade individual é a seqüência ou o complemento necessário do vínculo biológico".

Sobre o afeto, como elo mantenedor do instituto da família - embora longe da perfeição por muitos imaginada e querida -, ultrapassando as dificuldades e diversidades de características imprimidas à instituição nos diversos momentos históricos,

\footnotetext{
${ }^{99}$ DIAS, Maria Berenice. PEREIRA, Rodrigo da Cunha (coord.). Direito de Família e o novo código civil. Belo Horizonte, Del Rey, 2005, prefácio, pág. vii.

${ }^{100}$ CARBONERA, Silvana Maria. O papel Jurídico do Afeto nas Relações de Família. In: FACHIN, Luiz Edson. (coord.). Repensando Fundamentos do Direito Civil Brasileiro Contemporâneo. Rio de Janeiro: Renovar, 1998.

${ }^{101}$ LEITE, Eduardo de Oliveira. Procriações artificiais e o direito. São Paulo, Revista dos Tribunais, 1995.
} 
especialmente pelo uso pelo Estado e Igreja do instituto, ao lhe atribuir um caráter quase que exclusivamente matrimonializado, patrimonializado e sacralizado, diz Gisele Câmara Groeninga, "a família a isso, relativa e bravamente, resiste. O afeto é o substrato básico do "contrato de convivência" das famílias - este as caracteriza, ao mesmo tempo em que as torna vulneráveis às descaracterizações exercidas pelos mecanismos de controle social, que procuram imprimir-lhes ideologias distantes das bases de sua constituição. A família é anterior às demais instituições que tentam lhe dizer o que ela é e como ela deve agir para ser reconhecida como tal. Curiosa inversão, feita pelo Direito, que acabou mistificando a família a ponto de acharmos que algumas famílias são mais "de famílias" do que outras..."

$\mathrm{O}$ afeto sempre esteve presente no âmbito familiar, embora, em muitos momentos históricos, teve diminuída ou quase nula a sua presença ante os valores da sociedade, mas ainda assim, mesmo que desapercebido, estava lá, enquanto elo mantenedor do grupo. É este laço que dá as bases da estrutura familiar, que, por sua vez, proporciona o desenvolvimento e a formação da personalidade dos indivíduos que integram o grupo.

Amparada em José Lamartine Correa de Oliveira e Francisco José Ferreira Muniz, Silvana Carbonera, reconhecendo o afeto como elo nas famílias contemporâneas, escreveu: “a família contemporânea é tomada como a comunidade de afeto e entre-ajuda, espaço onde as aptidões naturais podem ser potencializadas e sua continuidade só encontra respaldo na existência do afeto" 103

A família é sempre socioafetiva. Isto porque ela é um fato social, é o espaço para a realização da dignidade da pessoa humana. A Constituição Federal de 1988, em seu artigo 226, diz que a família é a base da sociedade, logo é o mais importante grupo social, que merece, portanto, proteção do Estado. Contudo tal grupo, diferente dos demais, tem como elemento essencial, a afetividade.

Examinar o papel jurídico do afeto nas relações de família significa estudar um dos elementos sustentadores do modelo de família consagrado pela Constituição Federal. Neste sentido, aduz Pietro Perlingieri: "o sangue e os afetos são razões autônomas de justificação para o momento constitutivo da família, mas o perfil

102 GROENINGA. Giselle Câmara. Afetos, sexualidade e violência - A família desmistificada. In. DIAS, Maria Berenice e BASTOS, Eliene Ferreira. Família além dos mitos. Ed. Del Rey, Belo Horizonte, 2008, pág. 68.

${ }^{103}$ CARBOBERA. Silvana Maria. O papel jurídico do afeto nas relações de família. In. Fachin, Luiz Edson (org) Repensando fundamentos do direito civil brasileiro contemporâneo, Rio de Janeiro, Renovar, 1998, p. 291/292. 
consensual e a 'affectio' constante e espontânea exercem cada vez mais o papel de denominador comum de qualquer núcleo familiar." 104

A afetividade vem se consagrando como uma nova categoria jurídica no direito brasileiro, como princípio que preconiza, no âmbito da família, a solidariedade.

Juridicamente, pode-se dizer que a afetividade é um liame específico entre duas pessoas em razão do parentesco ou de outra fonte constitutiva da relação familiar. O livre arbítrio de amar que possui cada indivíduo faz com que o Direito louve a relação afetiva estabelecida entre os membros da família para garantir a dignidade do ser humano.

A noção de afeto é elemento essencial nas relações interpessoais que formam a família. As pessoas se unem, se mantêm unidas e até mesmo se separam em razão do afeto.

A palavra afeto tem uma origem etimológica muito controvertida. Vários significados dela emergem, segundo as dimensões desejadas, inclusive a filosófica. Segundo Sérgio Resende, teria origem latina: vem de 'ad', com significado de "para" e 'fectus', com o significado de fato ou feito, o que resultaria em feito um para o outro. ${ }^{105}$

$\mathrm{Na}$ filosofia, entendem-se, como afeto, as emoções positivas que se referem a pessoas. As emoções podem se referir a pessoas e coisas, os afetos, por sua vez, são emoções que acompanham algumas relações interpessoais, das quais fica excluída a dominação pela paixão. O afeto, então, é traduzido por atitudes como a bondade, a devoção, a proteção, o apego, a gratidão, a ternura.

Sob a ótica da Psicanálise, o afeto é a expressão de qualquer estado afetivo, agradável ou não, que se manifesta sob a forma de descarga. É um estado sentimental que se caracteriza, uma parte pela inervação física perceptível e outra, por uma perturbação peculiar do processo representativo. Ou seja, trata-se de qualquer espécie de sentimento que se associa a uma idéia, que, em razão da sua intensidade, provoca reações perceptíveis no indivíduo.

Para Freud afeto é a mais pura expressão da quantidade de energia pulsional frente às suas variações, ou seja, podem-se notar explosões afetivas de alegria e podem-se notar diminutas explosões de alegria.

\footnotetext{
${ }^{104}$ PERLINGIERI, Pietro. Perfis do direito civil: Introdução ao direito civil constitucional. Rio de Janeiro, Renovar, 1997, pág. 244.

${ }^{105}$ LÔBO, PAULO LUIZ NETTO. A família enquanto estrutura de afeto. In. DIAS, Maria Berenice e

BASTOS, Eliene Ferreira. Família além dos mitos. Ed. Del Rey, Belo Horizonte, 2008, pág. 254.
} 
A definição freudiana mais básica do afeto é tratar-se de um estágio final de um fator quantitativo, de uma energia chamada de soma de excitação ou quota de afeto, isto é, o elemento metapsicológico primordial. Em psicanálise, o afeto corresponde à descarga de energia no interior do corpo acompanhada de prazer ou desprazer conjugada à percepção da descarga ${ }^{106}$.

O afeto, enquanto representante da pulsão, assume tanto uma dimensão quantitativa como qualitativa. No que diz respeito à sua dimensão quantitativa temos a idéia de quantum de afeto (affektbertrag) - expressão por meio da qual Freud faz sobressair a economia do afeto, sendo designada por expressões como "energia pulsional", "energia de investimento", ou até mesmo "libido" quando a pulsão sexual é a única que está em causa. A dimensão qualitativa refere-se à impressão subjetiva em termos do que Freud considera como "processos que são sentidos como afetos". Nesse sentido o afeto pode ser entendido como a expressão qualitativa da quantidade de energia pulsional. Assim, Freud distingue o aspecto subjetivo do afeto e os processos energéticos pulsionais que o condicionam. $^{107}$

Explica Gisele Câmara Groeninga, que, "afeto é tudo aquilo que nos afeta, que nos move, é a energia presente no inconsciente e no consciente. Afeto, no senso comum, equivale ao amor. E a isso é necessário desmistificar. O afeto para a Psicanálise é essa energia com que se investem as representações, os símbolos, as pessoas, as coisas, as idéias e até as ideologias e mitos, imprimindo-lhes uma direção, um sentido, nas ações. Os afetos, esse quantum de energia psíquica, transformam-se de acordo com a nossa experiência, em qualidades, em sentimentos. Os afetos de amor e ódio não existem puros. Temos sempre nuanças afetivas. Por exemplo, nós temos vários graus de amor e de ódio, temos o afeto da depressão, da persecturidade, da culpa, da inveja, da gratidão, da solidariedade, do cuidado e da destrutividade, da cooperação e da competição, para citar alguns. Esses sentimentos são compostos de uma combinação entre amor e ódio que vamos aprender a balizar nas relações familiares, para, então, dar-lhes um sentido positivo. Essa é a função da família". ${ }^{108}$

\footnotetext{
${ }^{106}$ WINOGRAD, Monah; SOLLERO-DE-CAMPOS, Flávia; J. LANDEIRA-FERNANDEZ. Resenha: um diálogo entre a psicanálise e a neurociência. Psicologia: Teoria e Pesquisa. Vol. 21, nº 01, Brasília, 107 ARRAES. Ana Karenina. VIANA, Terezinha de Camargo. Afeto e dor: faces do luto na obra freudiana. Artigo publicado no site: http://www.estadosgerais.org/encontro/afeto e dor.shtml, acesso em 07/09/2009. ${ }^{108}$ GROENINGA. Giselle Câmara. Afetos, sexualidade e violência - A família desmistificada. In. DIAS, Maria Berenice e BASTOS, Eliene Ferreira. Família além dos mitos. Ed. Del Rey, Belo Horizonte, 2008, pág. 75.
} 
Como podemos observar, o afeto pode ser compreendido como um estado emocional que inclui toda a gama de sentimentos humanos, do mais agradável ao mais insuportável, manifestado de forma violenta, física ou psíquica, de modo imediato ou adiado.

Registra a psicanalista Clarissa Salazar que o afeto para a psicanálise "é originário na formação do inconsciente sendo este definido como uma invenção e só acontece em ato. Por isso, não há como fazer uma prevenção, uma vez que na própria evitação, está posto o desejo. Os afetos são o equivalente da energia psíquica, dos impulsos que afetam o organismo e se ligam a representações, a pessoas, objetos significativos. Transformam-se em sentimentos e dão um sentido às relações, e ainda influenciam nossa forma de interpretar o mundo". ${ }^{109}$

Sendo o afeto um estado emocional, capaz de afetar o indivíduo, ou seja, capaz de produzir sentimentos que possibilitem a formação de um elo do indivíduo com outras pessoas, relevante a qualidade deste elo que permeará os relacionamentos entre as pessoas. Isto porque o ser humano não nasce com um 'eu' pronto, irá constituir-se a partir de si e de suas relações familiares e sociais.

$\mathrm{O}$ afeto, registre-se, está sempre ligado àquilo que nos constitui como sujeitos desejantes em nossa relação com o outro semelhante.

Reside, aí, a importância da qualidade desta relação no âmbito familiar. O amor, o reconhecimento, a ajuda mútua, o amparo são elementos indispensáveis para a construção e identificação do indivíduo, para investir em si e no outro.

A afetividade é, pois, um aspecto necessário, complementar e indissociável no desenvolvimento do ser humano.

A Psicanálise veio, então, nos mostrar a diferença e a inter-relação entre a realidade objetiva e a subjetiva, de modo que, para a adequada interpretação e aplicação do Direito de Família há que se observar a verdade das relações, a realidade das famílias, mesmo que esta não atenda aos mitos que temos da família. É a intersubjetividade sinalizando os caminhos a serem trilhados pelos operadores do Direito de Família.

Sob o viés do Direito, o afeto pode ser entendido como elo formador e mantenedor de relações estabelecidas entre as pessoas, no âmbito familiar, quer seja por relações de conjugalidade, de paternidade ou parentesco, que viabiliza a valorização das pessoas e de seus interesses tanto individuais como, enquanto parte de um grupo familiar.

${ }^{109}$ Conferência apresentada na 2 $2^{\text {a }}$ Jornada Baiana de Psicologia Jurídica, realizada em 16 de maio de 2009. 
Nestas circunstâncias, o afeto, enquanto capacidade de afetar, influenciar e unir pessoas, é um estado emocional genuíno, natural, que não espera qualquer contraprestação, especialmente, quando falamos do amor e do carinho doados no âmbito familiar.

Neste sentido, a lição de Rolf Madaleno: "Afeto que deve ter manifestação espontânea, gerada por impulso natural de sentimentos que se estreitaram apenas por amizade, por vínculos de parentesco ou por qualquer outra modalidade com semelhante origem. Mas, sobretudo, afeto que jamais cogita qualquer forma de tarifação, porque respeita o afeto mecânico, com proteção sociocultural, envolvido por cristalina redoma a permitir a visão ingênua e translúcida, do modo simples e milenar do ser humano expressar os seus sentimentos de amor". ${ }^{110}$

E é este estado emocional, enquanto elo de união entre pessoas, que, observado como fato social e psicológico quando transferido para o fato jurídico, se traduz na afetividade jurídica, que, para Paulo Luiz Netto Lôbo, cria uma categoria própria no mundo do Direito ${ }^{111}$.

A inserção do afeto no Direito há tempos já é tema do movimento da repersonalização do Direito de Família, citado neste trabalho, trazido por Paulo Luiz Netto Lôbo. Lembramos que tal movimento se dá em direção à busca do que nos torna e nos qualifica como humanos.

A Constituição Federal de 1988 trouxe como seu princípio basilar a dignidade da pessoa humana em seu artigo $1^{\circ}$. A dignidade, segundo Alexandre de Moraes, pode ser traduzida como "um valor espiritual e moral inerente à pessoa, que se manifesta singularmente na autodeterminação consciente e responsável da própria vida e que traz consigo a pretensão ao respeito por parte das demais pessoas, constituindo-se um mínimo invulnerável que todo estatuto jurídico deve assegurar, de modo que, somente excepcionalmente possam ser feitas limitações ao exercício dos direitos fundamentais, mas sem menosprezar a necessária estima que merecem todas as pessoas enquanto seres humanos". 112

Assim, o direito à vida privada, à intimidade, à honra, à imagem, dentre outros, aparecem como consequência imediata da consagração da dignidade da pessoa

\footnotetext{
${ }^{110}$ MADALENO, Rolf Hanssen. A Multa Afetiva. Aspectos Processuais do Direito de Família. Revista Jurídica Del Rey, Belo Horizonte : Del Rey/IBDFAM, n. 8, p. 33, maio 2002. (Número especial).

${ }^{111}$ LÔBO, Paulo Luiz Neto. A família enquanto estrutura de afeto. In. DIAS, Maria Berenice e BASTOS, Eliene Ferreira. Família além dos mitos. Ed. Del Rey, Belo Horizonte, 2008, pág. 254.

${ }^{112}$ MORAES, Alexandre de. Direitos Humanos Fundamentais. Coleção Temas Jurídicos. $7^{\mathrm{a}}$ edição. Ed. Atlas, São Paulo, 2006.
} 
humana como fundamento da República Federativa do Brasil, esse fundamento afasta a idéia de predomínio das concepções transpessoalistas do Estado em detrimento da liberdade individual.

E, especialmente nas relações de família, a idéia de dignidade da pessoa humana encontra no novo texto constitucional de total aplicabilidade pelo Direito, considerada a família como célula da sociedade, sendo uma de suas expressões a liberdade - aqui entendida como a vontade de se unir e conviver - e o respeito aos direitos fundamentais do grupo familiar.

Da mesma forma, trouxe a Constituição os princípios da solidariedade e da convivência familiar: o primeiro, estabelecido no artigo $3^{\circ}$ da Constituição, particularmente no inciso I, traz a idéia de que pensar um no outro, em face do outro; existir é coexistir e o segundo, estabelecido no caput do artigo 227, remete ao direito à convivência em família, como forma de realização e desenvolvimento da cada componente do grupo.

Estes princípios - dignidade da pessoa humana, solidariedade e convivência familiar - por certo, fundamentam a afetividade, enquanto expressão da vontade do ser humano de compartilhar sua vida com entes queridos. É o afeto que expressa a vontade de estar e permanecer ou não junto a outra pessoa, por isso, revelou-se um elemento de grande importância tanto na constituição de uma família, assim como em sua dissolução.

Tratar da dignidade e da igualdade significa também abordar sua coexistência num ambiente dividido por duas ou mais pessoas: se ambas têm direitos idênticos, significa que a convivência somente será possível se houver a limitação da liberdade individual pela lei. Somente a existência do afeto faz com que pessoas restrinjam sua esfera de liberdade, renunciando a determinados desejos, para que outras também possam crescer e se desenvolver, pois o desenvolvimento de um produz efeitos benéficos a todas. Se assim não fosse, certamente não estaríamos falando de família, onde as pessoas decidem permanecer unidas por vontade própria, buscando a realização própria e a dos demais, respeitando a esfera da dignidade e da liberdade de cada sujeito. ${ }^{113}$

Pois bem, valorizadas a dignidade, a igualdade e a liberdade como diretrizes constitucionais, automaticamente, a solidariedade passa a ocupar maior espaço

${ }^{113}$ CARBONERA, Silvana Maria. O papel Jurídico do Afeto nas Relações de Família. In: FACHIN, Luiz Edson. (coord.). Repensando Fundamentos do Direito Civil Brasileiro Contemporâneo. Rio de Janeiro: Renovar, 1998, pág. 294. 
no âmbito da família, que, após inúmeras transformações, neste momento histórico, tem, consequentemente, como base, a afetividade.

E não é só, registra Luiz Edson Fachin, que “a Constituição de 1988, ao vedar o tratamento discriminatório dos filhos, a partir dos princípios da igualdade e da inocência, veio a consolidar o afeto como elemento de maior importância no que tange o estabelecimento da paternidade. Foi para a Constituição o que estava reconhecido na doutrina, na lei especial e na jurisprudência." 114

Não obstante a Constituição Federal não tenha trazido o princípio da afetividade expressamente em seu texto, emerge tal princípio, deste contexto. Até porque, princípios não são sempre explícitos, mas, todavia, ainda que implícitos, devem ser utilizados como orientadores da conduta do operador do direito.

Para Cláudia Lima Marques, Maria Cláudia Cachapuz e Ana Paula da Silva Vitória, "a isonomia, traduzida constitucionalmente na aplicação do conceito de igualdade, buscou solucionar, portanto, vazios legislativos para situações do mundo dos fatos que reclamavam por uma interpretação mais contemporânea. Interpretação que, por sinal, aos poucos era integrada na jurisprudência dos tribunais a partir da utilização de princípios gerais do direito e de análise comparativa a outros ordenamentos jurídicos. $\mathrm{O}$ mérito da Constituição Federal de 1988, por conseqüência, não foi o de inaugurar soluções a problemas do âmbito do direito de família, mas, sim o de obrigar a interpretação das leis infraconstitucionais a uma nova realidade material: a igualdade entre familiares nas suas relações de convívio (...) é que, prevendo o conceito de igualdade uma abertura do sistema para que os membros da família sejam considerados de forma isonômica como sujeitos de direitos, permite, de outra parte, o reconhecimento de suas individualidades e de um maior respeito a seus direitos fundamentais."

A Constituição Federal de 1988 foi, efetivamente, um marco no tocante aos valores da família brasileira. O princípio da dignidade da pessoa humana, inserido no artigo $1^{\circ}$, inciso III, da Constituição Federal, como fundamento do Estado Democrático de Direito, aliado ao princípio da solidariedade, previsto no artigo $3^{\circ}$, inciso I, permitem uma releitura, especialmente das relações familiares e do Direito de Família. Se considerarmos as relações dentro do ambiente familiar, constataremos que não mais é uma relação

\footnotetext{
${ }^{114}$ FACHIN, Luiz Edson. Comentários ao Novo Código Civil. Do Direito de Família. Do direito pessoal. Das Relações de Parentesco. Arts. 1.591 a 1.638. Vol. XVIII - Coord. Sávio de Figueiredo Feitosa -1 ${ }^{a}$ edição. Rio de Janeiro: Forense, 2003, pág. 27.

${ }^{115}$ MARQUES, Claudia Lima; CACHAPUZ, Maria Cláudia (col.) VITÓRIA, Ana Paula da Silva (col.). Igualdade entre Filhos no Direito Brasileiro Atual - Direito Pós-Moderno? Revista dos Tribunais, São Paulo, v. 764, 1999, pág. 19.
} 
patrimonializada, fator de ligação entre as pessoas, criou-se espaço para uma nova ordem, onde os vínculos predominantes são os socioafetivos, verificados, tanto nas relações entre pais e filhos - o vínculo não é mais exclusivamente biológico, como entre os cônjuges e companheiros.

As relações enaltecidas são as pessoais, que buscam a valorização das pessoas dentro do grupo familiar e a realização de seus interesses, pessoais e coletivos. E é a afetividade, enquanto elo de união do grupo familiar e elemento para o desenvolvimento dos indivíduos, que permite a plena realização dos princípios constitucionais da dignidade da pessoa humana e da solidariedade.

Neste sentido, é a lição de Silvana Maria Carbonera: "A moderna concepção jurídica de família, gradativamente construída, deslocou-se do aspecto desigual, formal e patrimonial para o aspecto pessoal e igualitário. Como consequiência, a importância dos interesses individuais dos sujeitos da família, isto é, da busca da felicidade como mola propulsora, provocou a valorização de vários elementos anteriormente secundários, dentre os quais se encontra a afetividade. Com a valorização das pessoas, seus interesses também o foram. Desta forma, os anseios relacionados a uma família construída sobre novos parâmetros se fizeram sentir e receberam ampla proteção constitucional, tendo a dignidade e a igualdade como princípios orientadores, assim como a possibilidade de tentar tantas vezes quantas forem necessárias a formação de uma família feliz.". ${ }^{116}$

Destarte, como visto, os princípios tem natureza cultural, do mesmo modo, possuindo o vínculo afetivo natureza cultural, pois está no mundo da cultura e não no mundo da natureza, deve então, a afetividade ser encarada pelo Direito como princípio, orientador das relações no Direito de Família, com base nas diretrizes constitucionais.

Assim, sobre o princípio da afetividade, escreveu Paulo Luiz Netto Lôbo: "Estou preferindo sempre utilizar o termo afetividade por que o tenho como uma transeficácia de um dado de realidade, da realidade psíquica, anímica, para o Direito. O Direito costuma apanhar na realidade da vida certas categorias e as faz suas. Quando faz, metamorfoseia essas categorias da história da realidade da vida e as transforma numa categoria própria, porque sua função é de regulação de conduta. É por isso que o princípio da afetividade - já o chamo de princípio - é uma norma e tem natureza normativa. Não é

116 CARBONERA, Silvana Maria. O papel Jurídico do Afeto nas Relações de Família. In: FACHIN, Luiz Edson. (coord.). Repensando Fundamentos do Direito Civil Brasileiro Contemporâneo. Rio de Janeiro: Renovar, 1998, pág. 290. 
uma proclamação retórica, não é meramente um projeto ético, é norma, norma que se extrai do ordenamento jurídico". 117

$\mathrm{O}$ afeto e sua expressão também encontram lugar no Direito quando o ordenamento trata dos Direitos da Personalidade, sobretudo o direito à integridade física $\mathrm{e}$ psíquica, necessariamente, nestas hipóteses, há observância ao princípio da afetividade. Registramos que o direito à integridade física e psíquica é também conhecido como o direito ao livre desenvolvimento da personalidade.

Na doutrina que trata das atuais tendências do Direito de Família, o afeto também já ocupa um lugar significativo, o que demonstra seu gradativo ingresso na esfera jurídica. A análise da jurisprudência também indica que os julgadores já estão cientes do valor do afeto nas relações de família. Da mesma forma, a preocupação com o aspecto afetivo também já se faz sentir na legislação.

E para ilustrar, registramos duas situações em que a afetividade tem aplicação no mundo jurídico, lembramos da relação entre cônjuges e companheiros, que, segundo o ordenamento, tem o dever de lealdade e considerações recíprocas, ou seja, relação que possui em sua base a afetividade. A extinção do afeto real leva à extinção dessas uniões, contudo, sobrevivem os deveres jurídicos. Portanto o afeto, mesmo desaparecendo no mundo real, não deixa de ser fundamento para o cumprimento de deveres jurídicos que persistem. Outra situação se verifica na relação entre pais e filhos, cuja afetividade é presumida, ainda que falte o afeto real entre eles. Nunca se extingue a afetividade da relação pais e filhos. Pai continuará sendo pai, mãe continuará sendo mãe e filho continuará sendo filho, até mesmo quando o pai ou a mãe perderem o poder familiar.

Tal fato pode ser percebido na legislação, especialmente quanto às relações paterno-filiais, pelo disposto nos artigos 1.593, 1.596, 1.597, V e 1.605. O legislador do Código Civil de 2002, também optou pela inclusão afetividade no conceito de paternidade.

A família passou, e passa, por transformações, hoje, o "contrato básico" entre os membros de uma família é o contrato afetivo. A força dominante da afetividade e desses vínculos reais de afeto, como único elemento da atualidade da família brasileira, para a estabilidade das relações familiares no Brasil, deve ser expressamente reconhecida pelo ordenamento jurídico.

${ }^{117}$ LÔBO, Paulo Luiz Netto. A família enquanto estrutura de afeto. In. DIAS, Maria Berenice e BASTOS, Eliene Ferreira. Família além dos mitos. Ed. Del Rey, Belo Horizonte, 2008, pág. 253. 
Registra Paulo Luiz Netto Lôbo que "a família recuperou a função, que, por certo, esteve nas suas origens mais remotas: a de grupo unido por desejos e laços afetivos, em comunhão de vida. O princípio jurídico da afetividade faz despontar a igualdade entre irmãos biológicos e adotivos e o respeito a seus direitos fundamentais, além do forte sentimento de solidariedade recíproca, que não pode ser perturbada pelo prevalecimento de interesses patrimoniais. É o salto, à frente, da pessoa humana nas relações familiares". ${ }^{118}$

Assim, a família contemporânea é tomada como a "comunidade de afecto e entre-ajuda", espaço onde as aptidões naturais podem ser potencializadas e sua continuidade só encontra respaldo na existência do afeto. É a família eudemonista, pois traduz o meio onde se acentuam as relações de sentimentos entre os membros do grupo: valorizam-se as funções afetivas da família que se torna o refúgio privilegiado das pessoas contra a agitação da vida nas grandes cidades e das pressões econômicas e sociais. ${ }^{119}$

Pois bem, a família encontrou sua unidade no afeto. Logo a afetividade desponta como elemento nuclear e definidor da união familiar, assim, vista como princípio será capaz de aproximar a instituição jurídica da instituição social.

E para isto, relevante a contribuição de outras áreas, especialmente da psicanálise, da sociologia e da psicologia. Pois, entendendo a instituição social família, compreendendo o ser humano, suas relações e motivações, poderá o Direito, de forma mais adequada e de maneira mais próxima atender aos anseios das pessoas.

Sobre o tema, explica Silvana Maria Carbonera: "Contudo, é sabido que, a partir de um certo momento, as relações particulares extrapolam seus limites iniciais, se fazem sentir no meio social e daí migram para a esfera jurídica. Inicialmente particulares, tais relações assumem caráter menos restrito e recebem proteção. Desta forma, o afeto, que começou como um sentimento unicamente interessante para aqueles que o sentiam, passou a ter importância externa e ingressou no meio jurídico. Tal relevância mostrou-se variável no decorrer dos tempos: se, em alguns momentos, a presença da affectio era presumida pela existência de relações de família, pois ficava à sombra da celebração, em outros, o afeto se revelou como o elemento responsável por lhes dar maior visibilidade. (...) Neste contexto, o afeto deve ocupar lugar de destaque (...) amplo é o espectro do afeto, mola

${ }^{118}$ LÔBO, Paulo Luiz Netto. Princípio jurídico da afetividade. Texto extraído do site Jus Navegandi. (http://jus2.uol.com.br/doutrina/texto.asp?id=527.

${ }_{119}$ CARBONERA, Silvana Maria. O papel Jurídico do Afeto nas Relações de Família. In: FACHIN, Luiz Edson. (coord.). Repensando Fundamentos do Direito Civil Brasileiro Contemporâneo. Rio de Janeiro: Renovar, 1998, pág. 291/292. 
propulsora do mundo e que fatalmente acaba por gerar conseqüências que necessitam se integrar ao sistema normativo legal."

$\mathrm{O}$ afeto nas relações familiares contemporâneas foi enaltecido, pois, valorizada a pessoa dentro do grupo familiar, permitiu-se que, cada um dos integrantes influenciasse ou modificasse o outro, visando o seu crescimento e realização pessoal. Tal influência pode ser exercida em razão da união e do bem-querer que existe entre os membros da família.

Lembra Giselda Maria Fernandes Novaes Hironaka: "Enfim, a nova família da contemporaneidade não é melhor nem pior do que os modelos familiares que a antecederam, mas é diferente deles, como disse inicialmente. Nesta família, os aspectos de positividade são bem vindos e são capazes, quiça, de dar ênfase aos aspectos que dizem respeito mais às trocas, às verdades, à cooperação, à complexidade e, principalmente, ao afeto entre seus membros. ${ }^{121}$

Essa concepção da família, como lugar de realização de afetos, difere da que se tinha como instituição natural, mantida em razão do patrimônio, da hierarquia e dependência. A afetividade, por sua vez, é o único elo entre duas pessoas livres. E o Direito é chamado para tutelá-la.

Sob esta perspectiva, Rolf Madaleno, assevera que "é para esse valioso universo de afeto de subsistência e outros valores que mais guardam riquezas de ordem subjetiva do que da subsistência material, a ciência jurídica vem desenvolvendo esse eficiente, moderno e célere instituto processual (...) no campo do Direito de Família, a sonhada pacificação social." 122

Todavia, alerta Gisele Câmara Groeninga, "não são apenas as famílias que estão em processo de mudança, também o estão todas as instituições. Há necessidade de o Judiciário também repensar o seu papel, a sua intervenção, inclusive para que não se constitua como uma intervenção que violente a própria família. Nesse sentido, há algumas lógicas do conflito voltadas para o Judiciário. Existe a lógica da força, a lógica da sentença,

\footnotetext{
${ }^{120}$ CARBONERA, Silvana Maria. O papel Jurídico do Afeto nas Relações de Família. In: FACHIN, Luiz Edson. (coord.). Repensando Fundamentos do Direito Civil Brasileiro Contemporâneo. Rio de Janeiro: Renovar, 1998, pág. 273.

${ }^{121}$ HIRONAKA, Giselda Maria Fernandes Novaes. A incessante travessia dos tempos e a renovação dos paradigmas: a família, seu status e seu enquadramento na pós-modernidade. In. DIAS, Maria Berenice e BASTOS, Eliene Ferreira. Família além dos mitos. Ed. Del Rey, Belo Horizonte, 2008, pág. 65.

${ }^{122}$ MADALENO, Rolf Hanssen. A Multa Afetiva. Aspectos Processuais do Direito de Família. Revista Jurídica Del Rey, Belo Horizonte : Del Rey/IBDFAM, n. 8, p. 33, maio 2002. (Número especial).
} 
a lógica da conciliação e finalmente, como se usa falar muito mais hoje em dia, a lógica da mediação interdisciplinar." 123

O Direito não deve determinar de que forma a família será constituída e de que forma se darão as relações entre seus membros. Deve, contudo, observar a realização dos princípios basilares do Direito de Família, na proteção da família e dos indivíduos, deixando, porém, às pessoas a liberdade quanto à formação e modo de condução das relações.

E, neste âmbito, relevante o papel do afeto enquanto elemento constitutivo da paternidade. Por certo, o elo pai-filho-mãe somente é completo se baseado no afeto, ou seja, se cultivada a relação de carinho, amor e dedicação diariamente, tendo em vista o desenvolvimento e realização pessoal de todos dentro, e em razão, do convívio familiar. A interpretação das normas de direito de família devem, pois, ser feitas tendo como parâmetros os princípios gerais que refletem a atual situação do instituto.

Com o reconhecimento do afeto como fundante das relações parentais, aliado a um elemento volitivo daí decorrente, se torna inafastável a consagração da posse de estado de filho como o instituto apto a permitir o acolhimento da filiação como fato socioafetivo.

Com a instalação da igualdade e da liberdade na família, o vínculo jurídico cedeu parte de seu espaço à verdade sócio-afetiva. Felicidade e afeto demarcaram seu espaço na noção jurídica de família em todas as esferas, a exemplo do que já havia acontecido na realidade social. Da família matrimonializada por contrato chegou-se à família informal, precisamente porque afeto não é um dever e a coabitação uma opção, um ato de liberdade. Da margem para o centro: os interesses dos filhos, qualquer que seja a natureza da filiação, restam prioritariamente considerados. ${ }^{124}$

E, neste contexto, registra Rolf Madaleno: “Aliás, é o afeto a matériaprima fundamental nas relações de filiação, de intensidade variável, contudo constante, oxigênio e sobrevida que responde pela adequada formação moral e psíquica dos filhos que são postos neste agitado mundo dos adultos, pessoas que, por vezes, de adultos nada demonstram, senão uma constante distorção na forma como educam e usam sua prole, comprometendo sua natureza humana, fragilizando sua estrutura moral, vilipendiando as

${ }^{123}$ GROENINGA. Giselle Câmara. Afetos, sexualidade e violência - A família desmistificada. In. DIAS, Maria Berenice e BASTOS, Eliene Ferreira. Família além dos mitos. Ed. Del Rey, Belo Horizonte, 2008, pág. 79

${ }^{124}$ CARBONERA, Silvana Maria. O papel Jurídico do Afeto nas Relações de Família. In: FACHIN, Luiz Edson. (coord.). Repensando Fundamentos do Direito Civil Brasileiro Contemporâneo. Rio de Janeiro: Renovar, 1998, pág. 291. 
relações parentais da prole com seus pais não guardiães, com ingerências ilícitas e movidas apenas por suas mesquinhas deficiências e carências pessoais". 125

Quanto à importância do afeto para o estabelecimento da paternidade, revela Silvana Maria Carbonera que: "uma terceira verdade vem sendo valorizada na esfera jurídica. $\mathrm{O}$ aspecto sócio-afetivo do estabelecimento da filiação, baseado no comportamento das pessoas que a integram, revela que talvez o aspecto aparentemente mais incerto, o afeto, em muitos casos é o mais hábil para revelar quem efetivamente são os pais. A incerteza presente na posse de estado de filho questiona fortemente a certeza da tecnologia. Ademais, a verdadeira paternidade decorre mais de amar e servir do que fornecer material genético. (...) A figura paterna é reconhecida pelo amor, desvelo e serviço com que se entrega ao bem da criança. E complementa a autora: "A verdade sócioafetiva, a seu turno, aproxima-se do modelo de família eudemonista, pautada que está no afeto, construído quotidianamente e não determinado desde o início da relação, revelando a valorização dos sujeitos. Desta forma, a construção de um novo sistema de filiação emerge como imperativa, posto que a alteração da concepção jurídica da família conduz necessariamente à mudança da ordenação jurídica da filiação, e o afeto, neste sentido, deve ocupar lugar de destaque". ${ }^{126}$

E, como adiante se demonstrará de forma minuciosa, o ordenamento jurídico brasileiro, há muito já adota o afeto como componente da relação paterno-filial, sendo a adoção a expressão mais significativa, seguido da inseminação artificial heteróloga. Os pais, ao decidirem adotar uma criança ou se submeterem a procedimentos bio-genéticos, revelam algo mais que o desejo de um herdeiro, o afeto, que estabelece tal relação familiar de forma voluntária.

Certamente a adoção é um instituto jurídico apto a colocar fim a qualquer sombra de dúvida que pudesse existir acerca da importância do afeto nas relações de família, especialmente em razão de representar o estabelecimento de uma relação jurídica voluntária, com fins a formar uma família, isto é, uma comunidade onde o afeto e a valorização recíproca de seus componentes sejam elementos relevantes.

Importante também o afeto, enquanto elemento estruturador da família, vez que, na formação da personalidade dos filhos, a principal influência de fatores sociais,

\footnotetext{
${ }^{125}$ MADALENO, Rolf Hanssen. A Multa Afetiva. Aspectos Processuais do Direito de Família. Revista Jurídica Del Rey, Belo Horizonte : Del Rey/IBDFAM, n. 8, p. 33, maio 2002. (Número especial).

${ }^{126}$ CARBONERA, Silvana Maria. O papel Jurídico do Afeto nas Relações de Família. In: FACHIN, Luiz Edson. (coord.). Repensando Fundamentos do Direito Civil Brasileiro Contemporâneo. Rio de Janeiro: Renovar, 1998, pág. 304.
} 
certamente, advém da estrutura familiar em que se encontra. Imprescindível, deste modo, o estabelecimento pleno do vínculo paterno-filial, que só se encontra, verdadeiramente, na afetividade.

Giselle Câmara Groeninga, sob a ótica da interdisciplina entre Direito e Psicanálise explica a importância do afeto na formação da personalidade: "temos observado um crescente valor dado ao afeto, uma qualidade da pessoa que finalmente ganha valor jurídico diferenciado. $\mathrm{O}$ afeto é matéria-prima da subjetividade, como também é ele que pavimenta as relações intersubjetivas. É na subjetividade das diferenças, e na intersubjetividade das semelhanças, que se forma a personalidade. E, com a contribuição da interdisciplina, deve-se buscar a necessária objetividade e a materialização objetiva dos Direitos da Personalidade. Neste sentido, a interface entre Direito e Psicanálise torna-se de rigor na necessária busca da objetividade que possa, assim, integrar o afeto."127

A afetividade, fator fundamental na socialização, permite a construção do indivíduo, é fator essencial no desenvolvimento intelectual do ser humano, e, ainda, permite a descoberta do prazer e do desejo de cada um em aprender, compartilhar, ajudar, sentimentos desenvolvidos dentro do ambiente familiar.

É indiscutível a relevância do afeto na constituição das relações familiares, que, com base nas diretrizes constitucionais, deve ser encarado como princípio jurídico, o princípio da afetividade.

\section{PATERNIDADE. PROTEÇÃO DOS FILHOS NA CONSTITUIÇÃO DE 1988}

Para se falar de paternidade é necessário enfocar os três momentos da relação paterno-filial, que hoje se interligam: a paternidade jurídica (imposta pela ordem jurídica), a paternidade biológica (dado conquistado pela medicina genética - DNA) e, a paternidade sócioafetiva (dado cultural).

Antigamente, tínhamos a verdade jurídica como premissa da paternidade, legítimo era o filho biológico, nascido dos pais unidos pelo matrimônio. A família era matrimonializada, patriarcal e hierarquizada, era, então, de extrema relevância a origem da filiação, vez que, sua legitimação dela dependia, já que considerada a família uma comunidade de sangue calcada no casamento.

\footnotetext{
${ }^{127}$ GROENINGA. Giselle Câmara. Os direitos da personalidade e o direito a ter uma personalidade. In. Aspectos psicológicos na prática jurídica. Ed. Milenium, $2^{\text {a }}$ Ed. 2008, pág. 100.
} 
A partir do abrigo jurídico de uma determinada concepção de família, o Direito organiza as relações internas de seus membros e dela com a sociedade. Então, em face da necessidade de estabelecer, no âmbito da família a filiação paternal o sistema se vale de alguns mecanismos. Diante da certeza da figura da mãe, quando casada, opera a presunção de paternidade do marido - 'pater is est quem nuptia demonstrat', e se não for casada, a filiação poderia ser estabelecida pelo reconhecimento voluntário ou pela investigação de paternidade.

A função da presunção é permitir o estabelecimento da paternidade pelo simples fato do nascimento. Logo o filho nascido de mulher casada é filho do marido desta mulher, portanto é automático o estabelecimento da relação paterno-filial.

Pai é aquele que o sistema jurídico definiu como tal. Nem sempre coincidem as figuras do pai biológico com a do pai jurídico, e, nestes casos, o sistema faz prevalecer a verdade jurídica sobre a verdade biológica.

Lembra Luiz Edson Fachin que "desse modo, ao centrar as preocupações na instituição familiar e nos princípios que visam protegê-la, o legislador deferiu amparo privilegiado da "honra e da paz familiar" cuidando primordialmente dos interesses da instituição acima dos interesses das pessoas que a compõe, particularmente os filhos. Mesmo quando evidencia a posição pai como chefe da família, o Código tem em mira mais a instituição de que a pessoa do marido em si mesma". ${ }^{28}$

As hipóteses de investigação e contestação de paternidade eram limitadas e, esta última, apresentava prazos exíguos. Todavia, para o Estado, desta forma, o estabelecimento da paternidade, promovia a defesa da família, fincada no matrimônio, assegurando a paz doméstica, uma vez que, vinha com um conjunto de regras claramente definidas. De um lado, se evitava o escândalo produzido na sociedade pela investigação de paternidade ou maternidade nos casos de filhos extramatrimoniais, dado que se exporiam relações sexuais condenadas e reprovadas pelo direito e moral, de outra, a negatória da paternidade legítima é cuidadosamente tratada para tornar difícil o afastamento da presunção 'pater is est', ainda que houvesse um distanciamento entre a paternidade jurídica e a biológica, o legislador priorizou o que acreditava ser o bem-estar familiar.

No Brasil, a discriminação dos filhos em razão de sua origem, em prol da preservação da família matrimonializada, data de longa data.

\footnotetext{
${ }^{128}$ FACHIN, Luiz Edson. Estabelecimento da Filiação e Paternidade Presumida. Ed. Fabris, Porto Alegre, 1992, pág. 46.
} 
As Ordenações Filipinas já distinguiam os filhos em legítimos e ilegítimos, se fruto de uma relação de matrimônio dos pais, ou não. Os ilegítimos, por sua vez, eram classificados em naturais e espúrios. Os filhos naturais eram os nascidos de pais não casados, não havendo, todavia, impedimento matrimonial. Já os filhos espúrios, eram os provindos de relação com alguma forma impedimento dos pais para o casamento, quer de parentesco, religioso ou matrimonial, quando eram considerados adulterinos.

O Decreto 181 de 24/01/1890, após a proclamação da República, permitiu o reconhecimento dos filhos extramatrimoniais por confissão espontânea, por escritura pública, no termo de nascimento ou em outro documento autêntico oferecido pelo pai. Todavia os filhos espúrios não possuíam direitos hereditários.

O Código Civil de 1916 manteve a distinção entre os filhos legítimos e ilegítimos. Segundo a redação original, legítimos são os filhos concebidos na constância do casamento, ainda que anulado ou nulo, se contraiu de boa-fé (artigo 337), sendo que os filhos legitimados são em tudo equiparados aos legítimos (artigo 352). A legitimação é um efeito do casamento dos pais, tornando legítimos os filhos havidos antes do matrimônio, ou que já estavam concebidos (artigo 353). Por sua vez, ilegítimos são os filhos cujos pais não estão unidos pelo laço do casamento, distinguindo-se em naturais, se entre os genitores não havia impedimento matrimonial na época da concepção, e espúrios, se existia impedimento dirimente absoluto. Por sua vez, os filhos espúrios podiam ser incestuosos e adulterinos. Incestuosos, os filhos de parentes ou afins em grau proibido para o casamento. E adulterinos, os filhos de homem casado ou de mulher casada com outra pessoa, que não o cônjuge.

Cumpre registrar que sob a égide do Código Civil de 1916 apenas era admitida a ação investigatória nas seguintes hipóteses (art. 363): I. se ao tempo da concepção a mãe estava concubinada com o pretendido pai; II. Se a concepção do filho reclamante coincidiu com o rapto da mãe pelo suposto pai, ou suas relações sexuais com ela; III. Se existir escrito daquele a quem se atribuiu a paternidade, reconhecendo expressamente. Como se vê, maneira de muito restrita e limitada.

Admitia a lei, com base nas restritas hipóteses dos artigos 340, incisos I e II, e 3.42, do CC, que o marido impugnasse a paternidade, em prazos decadenciais exíguos (art. 178, $\S \S 3^{\circ}$ e $4^{\circ}$, inc. I, do CC) que iam de dois a três meses. Os limites da impugnação da paternidade segundo esse sistema eram tão estritos, e na sua formulação não esteve presente a preocupação que fugisse ao favor legitimitatis. Isso equivale a reconhecer nessa 
ordem de idéias o modelo matrimonial, patriarcal e hierarquizado que está na base dessa estrutura jurídica da família. ${ }^{129}$

Ademais, presumidos como matrimoniais os filhos concebidos na constância do casamento, a lei estabelecia ainda, que só o marido poderia contestar a paternidade dos filhos de sua mulher. Conferia-se, assim, ao marido o monopólio do exercício da ação, refletindo, pois, o regime patriarcal da família.

Em consonância com tal ordem de idéias, fora dos limites estreitos estabelecidos e se impondo diante da verdadeira filiação do ponto de vista biológico, prevalece a "verdade jurídica" ainda que para abrigar uma filiação fictícia.

Após a entrada em vigor do Código Civil de 1916, inúmeras normas jurídicas foram promulgadas com o intuito de alterar concepção codificada de filiação, visando, eliminar a desigualdade entre a família legítima e a natural.

Já alertava José Luiz Gavião de Almeida: "a família e sua regulamentação, no Brasil e no mundo, vem sofrendo profundas e incessantes modificações. Mais especificamente, a equiparação dos filhos já vinha lentamente espalhada em nosso direito posto, ganhando acentuado tratamento no direito constituendo. Tal conquista, devida por certo aos apelos de nossos doutrinadores, incansáveis em pugnar pela igualdade de direitos àqueles que não tinham contribuído pela dessemelhança que tratavam."130

Mas, somente em 1988, com a Constituição Federal, com uma profunda alteração das normas e princípios do direito de família, foi reconhecida a igualdade da filiação, proibidas quaisquer discriminação quanto à sua origem.

O artigo 227, parágrafo $6^{\circ}$ da Constituição Federal, diz que, "os filhos, havidos ou não da relação do casamento, terão os mesmos direitos e qualificações, proibidas quaisquer designações discriminatórias relativas à filiação”.

A família na Constituição Federal de 1988 pode ter origem matrimonial ou não. Além disso, rompe-se com o caráter patriarcal antes evidenciado pela chefia da sociedade conjugal atribuída ao marido e agora afastada pelo princípio da igualdade entre cônjuges.

${ }^{129}$ FACHIN, Luiz Edson. A tríplice paternidade dos filhos imaginários. ALVIM. Teresa Arruda (coord.). Repertório de Jurisprudência e Doutrina sobre Direito de Família: Aspectos constitucionais, civis e processuais. São Paulo. Revista dos Tribunais, 1998, v. 02, pág. 180.

${ }_{130}$ ALMEIDA, José Luiz Gavião. O Direito de Família e a Constituição de 1998. In Carlos Alberto Bittar (Org.). O Novo Estatuto da Filiação, São Paulo, Saraiva, 2003, pág. 162. 
O princípio da igualdade trazido pela Constituição de 1988 é princípio essencial, considerado verdadeiramente como pedra angular da reforma, sobretudo para a criança que evita qualquer discriminação em razão de sua origem.

A adoção plena do princípio da igualdade entre todos os filhos implicou a mudança do modelo familiar antigo, mais afeito ao patrimônio e menos ao afeto: "ao longo do século XX, essa visão patrimonialista da família que emergia das disposições da Lei Civil foi sendo aos poucos superada, flexibilizando-se mediante legislação extravagante a rigidez original. A realidade social se impôs, particularmente com relação aos filhos, de modo a amparar os havidos fora do casamento, de todo preteridos se adulterinos ou incestuosos. O espaço reservado aos filhos tidos fora do casamento somente agora se projetam, com clareza e amplitude no texto constitucional, pois "as relações denominadas espúrias, adulterinas ou concubinárias nenhum direito possuíam. Os filhos havidos fora do casamento sempre foram alvo de enorme gama de pechas de conteúdo pejorativo e discriminatório. Seu destino era a invisibilidade, pois não podiam buscar o reconhecimento da própria identidade". ${ }^{131}$

Novas perspectivas advieram do princípio ético e jurídico da igualdade, bem assim da 'repersonalização' das relações jurídico-familiares, quando conferido o devido respeito aos direitos, especialmente das crianças que, até o advento da Constituição de 1988, tinham os seus direitos fundamentais mais atingidos e desrespeitados. Muitas vezes, eram as crianças que assumiam as duras consequências, por atos que não praticaram, mas acabaram se tornando a principal vítima.

Para José Luiz Gavião de Almeida, "a nova Carta Constitucional, por outro lado, erigindo como princípio a "paternidade responsável" (art. 226, §7º), pôs fim à existência de direitos dos filhos em relação aos pais, desvinculados do estado de filiação. Esses direitos, aliás, eram apenas paliativo encontrado em face dos escrúpulos do legislador que, arvorando-se em defensor da moral e dos bons costumes daqueles que não os prezavam, impedia a formação de inúmeras relações parentais apenas porque não tinham elas como fonte a família legítima. O art. 227 do novo texto constitucional resume a proteção legal dos infantes, e dos filhos enquanto tais, ao estabelecer que "É dever da família, da sociedade e do Estado assegurar à criança e ao adolescente, com absoluta prioridade, o direito à vida, à saúde, à alimentação, à educação, ao lazer, à

\footnotetext{
${ }^{131}$ FACHIN, Luiz Edson. Comentários ao Novo Código Civil. Do Direito de Família. Do direito pessoal. Das Relações de Parentesco. Arts. 1.591 a 1.638. Vol. XVIII - Coord. Sávio de Figueiredo Feitosa -1 ${ }^{a}$ edição. Rio de Janeiro: Forense, 2003, pág. 42.
} 
profissionalização, à cultura, à dignidade, ao respeito, à liberdade e à convivência familiar e comunitária, além de colocá-los a salvo de toda forma de negligência, discriminação, exploração, violência, crueldade e opressão". ${ }^{132}$

A jurisprudência foi, portanto, valorizando o estatuto da igualdade entre os filhos, bem como foi aproximando a verdade jurídica da verdade de sangue e, também, da verdade sociológica e afetiva da filiação. Tal posição revela a inclinação para colocar no centro de suas considerações, os melhores interesses da filiação. Com isso, visivelmente, rechaçou uma percepção calcada na exclusividade das atenções patrimoniais, para enfocar a pessoa.

E então, em 17/10/1989, através da Lei $n^{\circ} 7.841$, no plano da legislação ordinária foi expressamente afastada a proibição do reconhecimento dos filhos espúrios, com a revogação do artigo 358 do Código Civil de 1916.

Verifica-se, neste momento, uma evolução da legislação em matéria de filiação. Passou-se a tutelar os direitos do filho, qualquer que fosse o estado de sua concepção, quer seja dentro ou fora do âmbito do lar conjugal, constituído ou não pelo casamento. Permite-se a dissociação entre filho e casamento ante a possibilidade de reconhecimento dos filhos espúrios.

A pessoa do filho passa a ser o foco da tutela pelo Estado e não mais a instituição do casamento. Valoriza-se o ser humano e a sua dignidade.

Com as novas diretrizes constitucionais, para Guilherme Calmon Nogueira da Gama: “As relações familiares, portanto, passaram a ser funcionalizadas em razão da dignidade de cada partícipe. A efetividade das normas constitucionais implica a defesa das instituições sociais que cumprem o seu papel maior. A dignidade da pessoa humana, colocada no ápice do ordenamento jurídico, encontra na família o solo apropriado para o seu enraizamento, daí a ordem constitucional dirigida ao Estado no sentido de dar especial e efetiva proteção à família, independentemente da sua espécie." 133

O novo texto constitucional, de maneira inequívoca, acolheu princípio da igualdade de todos os filhos - artigo. 227, $\S 6^{\circ}$, da CF. Princípio, aliás, que restou consagrado na Declaração Universal dos Direitos do Homem da Organização das Nações Unidas, de 10 de dezembro de 1948, através dos artigos $1^{\circ}$ e $7^{\circ}$. Os filhos, então, de forma

\footnotetext{
${ }^{132}$ ALMEIDA, José Luiz Gavião. O Direito de Família e a Constituição de 1998. In Carlos Alberto Bittar (Org.). O Novo Estatuto da Filiação, São Paulo, Saraiva, 2003, pág. 167.

133 GAMA, Guilherme Calmon Nogueira. Filiação e reprodução assistida: introdução ao tema sob a perspectiva civil-constitucional, in TEPEDINO, Gustavo. Problemas de direito civil constitucional, Rio de Janeiro, Renovar, 2002, p. 520.
} 
efetiva, tiveram equiparação em direitos. "E se aboliu a injusta regra de irresponsabilizar os pais por ilícitos que eles cometeram, aplicando a sanção aos filhos, embora inocentes, consistente em relegá-los ao abandono por desamparo da proteção legal”, como registra José Luiz Gavião de Almeida. ${ }^{134}$

Claudia Lima Marques, Maria Cláudia Cachapuz e Ana Paula da Silva Vitória, asseveram que "ao contrário da visão moderna, de proteção exclusiva ao núcleo familiar, a Constituição Federal permitiu que se reconhecessem constitucionalmente, em perspectiva pós-moderna, dois princípios eventualmente considerados antagônicos: o de proteção à unidade familiar e o de proteção aos filhos, considerados em sua individualidade. A Constituição brasileira, ao consagrar o princípio da igualdade dos filhos, o fez de maneira bastante peculiar. Em primeiro lugar, tratou de positivamente afirmar a igualdade de direitos independentemente da origem dos filhos (havidos ou não da relação de casamento ou por adoção), e, em segundo lugar, negativamente, através da proibição de designações discriminatórias. Na verdade o que se fazia era punir o mais próximo, na falta de outros, a vítima de uma situação para a qual não contribuiu. $\mathrm{O}$ tratamento era profundamente injusto e gerava uma situação discriminatória e inaceitável em relação aos filhos, fruto da hipocrisia inculcada na sociedade e refletida na legislação, como se as leis, por si sós, pudessem mudar os padrões sociais efetivos. O que se estava fazendo, para muitos, era acobertar a "irresponsabilidade masculina", em vez de incentivar a responsabilidade, justamente o que o princípio da igualdade entre os filhos consagra". ${ }^{135}$

Com supressão do sistema discriminatório da filiação em razão de sua origem que impossibilitava o reconhecimento de filhos matrimoniais, aliado à evolução da ciência, permitiu-se perquirir a verdadeira ascendência genética. Houve, então, um período em que a verdade biológica converteu-se na "verdade real" da filiação em decorrência dos fatores históricos, religiosos e ideológicos.

Por força do $\$ 6^{\circ}$ do artigo 227 da Constituição Federal, qualquer filho pode ser reconhecido, voluntária ou judicialmente. É inerente ao princípio da igualdade o direito do filho em estabelecer a ascendência biológica, qualquer que seja.

Afirma Luiz Edson Fachin: "O pai pode não ser aquele a quem a lei presuntivamente atribuiu a paternidade; essa verdade jurídica, emergente da presunção

\footnotetext{
${ }^{134}$ ALMEIDA, José Luiz Gavião. O Direito de Família e a Constituição de 1998. In Carlos Alberto Bittar (Org.). O Novo Estatuto da Filiação, São Paulo, Saraiva, 2003, pág. 178.

${ }_{135}$ MARQUES, Claudia Lima; CACHAPUZ, Maria Cláudia (col.) VITÓRIA, Ana Paula da Silva (col.). Igualdade entre Filhos no Direito Brasileiro Atual - Direito Pós-Moderno? Revista dos Tribunais, São Paulo, v. 764,1999 , pág. $22 / 25$.
} 
'pater is est', cujo caráter praticamente absoluto foi consagrado pelo sistema clássico deve ceder à busca da verdadeira paternidade, do ponto de vista biológico" 136

Neste contexto, são promulgados o Estatuto da Criança e do Adolescente, Lei $n^{\circ} 8.069 / 90$, que, não apenas repetiu o princípio constitucional da igualdade entre os filhos, como também estabeleceu que o reconhecimento do estado de filiação é direito personalíssimo, indisponível e imprescritível, podendo ser exercitado contra os pais ou seus herdeiros sem qualquer restrição; e em 1992 a Lei 8.560 tratou do reconhecimento voluntário e forçado de paternidade, inclusive de forma oficiosa. Foi então, revogado tacitamente o artigo 357 do Código de 1916.

Seguindo a orientação constitucional do princípio da paternidade responsável, o artigo $4^{\circ}$ do Estatuto da Criança e do Adolescente dispõe que "é dever da família, da comunidade, da sociedade em geral e do poder público assegurar, com absoluta prioridade, a efetivação dos direitos referentes à vida, à saúde, à alimentação, à educação, ao esporte, ao lazer, à profissionalização, à cultura, à dignidade, ao respeito, à liberdade e à convivência familiar e comunitária".

É interesse do Estado e da sociedade, pois, o estabelecimento das relações paterno-filiais, visando à proteção dos menores, para que tenham assegurados seus direitos básicos, determinados pela norma constitucional.

Neste sentido, registra Zeno Veloso que "a determinação da paternidade não é, assim, um interesse meramente individual, exclusivamente privado. Interessa ao Estado, interessa à sociedade, e interessa muito. Porque interessa que uma criança tenha pai, que se defina o seu genitor, que apareça o responsável pela sua geração, para que a crie, eduque, alimente, proteja, participe do seu desenvolvimento, oriente a sua vida. Se não com amor e afeto - porque esses nobres sentimentos não podem ser impostos -, pelo menos comparecendo com meios e recursos para que a criança tenha uma existência digna e possa ser útil ao país." 137

De fato, com o reconhecimento da paternidade, passa o filho a ter direito de usar o patronímico do pai, ter registrada a sua ascendência; se menor, submeter-se ao poder familiar - aí inseridos o dever de guarda, sustento e educação do pai, atendido assim, o principio da dignidade da pessoa humana, permitindo o pleno desenvolvimento sadio do menor.

\footnotetext{
${ }^{136}$ FACHIN, Luiz Edson. Estabelecimento da Filiação e Paternidade Presumida. Ed. Fabris, Porto Alegre, 1992, pág. 169.

${ }^{137}$ VELOSO, Zeno. Direito brasileiro da filiação e paternidade. Ed. Malheiros, 1997, pág. 123.
} 
O Código Civil de 2002, em linha com as diretrizes constitucionais, em seu artigo 1596, repetiu o dispositivo constitucional (artigo 227, $\S 6^{\circ}$ ) e trouxe em seu corpo o princípio da igualdade dos filhos.

Manteve o legislador de 2002, de um lado, a tradicional presunção 'pater is est' e, de outro, introduz, nesse âmbito, a técnica da reprodução humana (fecundação artificial homóloga e inseminação homóloga e inseminação heteróloga), além da previsão quanto aos embriões excedentários.

Aponta, Luiz Edson Fachin que "reveste-se de grande importância para o ordenamento jurídico brasileiro a questão à presunção de paternidade, posto que na impossibilidade de se averiguar diretamente a paternidade, esta encontra-se embebida na noção de presunção jurídica. Esta, entretanto, não é de natureza jurídica absoluta, mas é essencialmente relativa (iuris tantum), já que pode ser contestada pelo marido, ou por seus ascendentes e descendentes quando este for incapaz ou morrer durante o transcorrer de ação negatória da paternidade em que é proponente, por meio da produção de provas que contrariem esse fato." $" 138$

De qualquer modo, reputam-se concebidos na constância do casamento, logo sujeitos à presunção relativa de paternidade, os filhos: a) nascidos há pelo menos 180 dias após configurada a convivência conjugal, de modo que resta ao pai ou marido a titularidade de ação imprescritível negatória de paternidade, posto que somente a ele é reservado o direito de contestar a presunção de paternidade; b) nascidos dentro dos 300 dias posteriores à dissolução do casamento por morte, separação ou anulação; c) frutos de fecundação artificial homóloga, mesmo que falecido o marido, desde que este tenha previamente anuído a utilização do material fertilizante; d) aqueles oriundos da concepção artificial homóloga, desde que contenha anuência expressa do casal; e) nascidos de inseminação artificial heteróloga, na condição de ter o marido dado prévia autorização ${ }^{139}$.

Em tema de presunção da paternidade, a nova disciplina traduz uma perspectiva detectada pela doutrina: "mediante a previsão da determinação da paternidade

\footnotetext{
${ }^{138}$ FACHIN, Luiz Edson. Comentários ao Novo Código Civil. Do Direito de Família. Do direito pessoal. Das Relações de Parentesco. Arts. 1.591 a 1.638. Vol. XVIII - Coord. Sávio de Figueiredo Feitosa $-1^{a}$ edição. Rio de Janeiro: Forense, 2003, pág.51.

${ }^{139}$ Aqui cumpre registrar que na I Jornada de Direito Civil do Conselho da Justiça Federal, o Enunciado 130 faz uma proposição sobre o artigo 1.601 do Código Civil. Sua redação atual: "Cabe ao marido o direito de contestar a paternidade dos filhos nascidos de sua mulher, sendo tal ação imprescritível. Parágrafo único: Contestada a filiação, os herdeiros do impugnante têm direito de prosseguir na ação.” Redação proposta: "Cabe ao marido o direito de contestar a paternidade dos filhos nascidos de sua mulher, sendo tal ação imprescritível. Parágrafo primeiro. Não se desconstituirá a paternidade caso fique caracterizada a posse do estado de filho. Parágrafo segundo. Contestada a filiação, os herdeiros do impugnante têm direito de prosseguir na ação.
} 
jurídica a partir da autorização do marido para a realização de inseminação artificial heteróloga, vem demonstrado, pelo novo Código Civil brasileiro, o amparo legal a mais uma hipótese de esvaziamento do conteúdo biológico da paternidade". ${ }^{4}$

Registra Silvana Maria Carbonera que "o exame de DNA do ser humano permite à ciência estabelecer, com precisão quase absoluta, a origem genética de uma pessoa. Pai e mãe deixaram de ser somente estabelecidos juridicamente para serem revelados pelo laudo." 141

Todavia o movimento que amparava a filiação biológica como verdade absoluta da filiação notou uma outra realidade, a verdadeira paternidade não pode circunscrever-se na busca de uma precisa informação genética, mais do que isso, exige uma concreta relação paterno-filial, donde emerge a filiação sócioafetiva. Portanto, em razão da evolução da sociedade e com os novos paradigmas constitucionais, da dignidade da pessoa humana e dos direitos da personalidade, precisamos dar o devido valor à afetividade - enaltecendo a paternidade socioafetiva.

$\mathrm{O}$ apelo à transcendência do conteúdo biológico da paternidade se manifesta também, sutil e expressivo, quando os liames do sangue parecem insuficientes a assumir um relacionamento mais profundo entre pais e filhos.

De fato, mesmo com as facilidades para o reconhecimento dos laços de filiação por meios biotecnológicos avançados, como o exame de DNA, mister ter-se em mente que a simples identificação biológica não estabelece os laços de filiação esperados. Concedem-se direitos, mas não o afeto essencial para o desenvolvimento da criança.

Em outras palavras, explica Maria Christina Almeida, "a filiação não é um dado ou um determinismo biológico, ainda que seja da natureza do homem o ato de procriar. Em muitas das vezes, a filiação e a paternidade derivam de uma ligação genética, mas esta não é o bastante para a formação e afirmação do vínculo, é preciso muito mais. É necessário construir o elo, cultural e afetivamente, de forma permanente, convivendo e tornando-se, cada qual, responsável pelo elo, dia após dia (...) o elo que une pais e filhos é,

\footnotetext{
${ }^{140}$ FACHIN, Luiz Edson. Comentários ao Novo Código Civil. Do Direito de Família. Do direito pessoal. Das Relações de Parentesco. Arts. 1.591 a 1.638. Vol. XVIII - Coord. Sávio de Figueiredo Feitosa -1 ${ }^{a}$ edição. Rio de Janeiro: Forense, 2003, pág.53.

${ }^{141}$ CARBONERA, Silvana Maria. O papel Jurídico do Afeto nas Relações de Família. In: FACHIN, Luiz Edson. (coord.). Repensando Fundamentos do Direito Civil Brasileiro Contemporâneo. Rio de Janeiro: Renovar, 1998, pág. 304.
} 
acima de tudo, socioafetivo, moldado pelos laços de amor e solidariedade, cujo significado é muito mais profundo do que o elo biológico." 142

O liame genético, por si só, não pode explicar a base real das relações paterno-filiais. A paternidade exige mais do que laços de sangue. O dado biológico é insuficiente para determinar a paternidade. A paternidade se estabelece por laços afetivos e se desenvolve como função, é, também, um dado cultural.

Neste contexto, afirma João Baptista Villela, "as transformações mais recentes por que passou a família, deixando de ser unidade de caráter econômico, social e religioso para se afirmara fundamentalmente como grupo de afetividade e companheirismo, imprimiram considerável reforço ao esvaziamento biológico da paternidade. Tanto mais quanto é certo que esse movimento evolutivo, transportando a família de uma idade institucionalista para uma idade eudemonista, ocorre em período de extraordinária floração da tecnologia biomédica. O controle da natalidade, tornado possível graças ao melhor conhecimento da fisiologia da reprodução, permitiu separar a atividade sexual do fenômeno procriativo. O impacto desta ruptura sobre as ciências do comportamento talvez só encontre equivalente, dentro da cultura contemporânea, ao produzido pela fissão nuclear nas ciências da natureza. Chegamos à plenitude desse novo estágio, os filhos, mais do que nunca, serão experimentados não como o salário do sexo, mas como o complemento livremente buscado e assumido de um empenho de personalização, que lança suas raízes no mais poderoso dinamismo transformacional do homem, que é o dom de si mesmo." 143

Podemos dizer, então, que são três as origens da filiação, a legal, a biológica e a afetiva. Contudo atualmente não há como prevalecer exclusivamente a filiação legal ou biológica, caso nesta relação o pai não tenha assumido a função de pai e entre pai e filho não tenham sido estabelecidos laços afetivos.

Assim, a lição de Belmiro Pedro Welter, que "segundo a doutrina, três são as verdades da filiação: verdade legal, verdade sócio-afetiva e verdade biológica. Mas, atualmente, diante do moderno Direito de Família, não mais se admite o estabelecimento

${ }^{142}$ ALMEIDA, Maria Christina. A Paternidade Sócioafetiva e a Formação da Personalidade. O Estado e os Estados de Filiação. Revista Jurídica Del Rey, Belo Horizonte : Del Rey/IBDFAM, 2002, n. 8, p. 24, maio 2002. (Número especial).

${ }^{143}$ VILLELA. João Baptista. Desbiologização da Paternidade. Revista Forense, jul-ago-set 1980, p. 49. 
da filiação legal, denominada ficção jurídica ou ficta, restando apenas a verdade genética e sócio-afetiva." 144

Registramos que a desvalorização da verdade biológica como absoluta na determinação da paternidade não representa, contudo, a substituição de um modelo por outro, mas a construção de uma nova paternidade jurídica, em que os modelos, com maior ou menor extensão, influenciam nas diversas formas de organização familiar.

De forma semelhante, no Direito Argentino, ensina Marisa Herrera, que o direito de filiação apresenta uma tripla fonte: 1) a filiação biológica ou por natureza - tal como reza o artigo 240 do Código Civil Argentino, 2) a procriação humana assistida e 3) a filiação adotiva. Estas três fontes de filiação - com maior ou menor extensão - interessam e repercutem sobre as distintas formas de organização familiar" 145

Da paternidade obstada, pela lei codificada da exclusão, à paternidade revelável a qualquer meio, vai tomando corpo um pai juridicamente fragmentado na travessia da relação unitária à conformação plural da família. Assim, leciona Luiz Edson Fachin, "Não se trata apenas de uma dilaceração conceitual. Cogita-se de um repensar do sentido e do alcance da paternidade em diversas direções. Nasce, pois, a paternidade plural, emergente da crise que sofreu a percepção tradicional da paternidade e da superação do desenho exclusivamente patrimonial e sucessório da relação paterno-filial. Na pluralidade, as soluções não estão adredemente postas à disposição dos fatos, mas a dimensão construtiva dos fenômenos sociais edifica equacionamentos, menos definitivos que antes". 146

Nada obstante algumas idéias já podem ser assentadas no desenho jurídico da paternidade em exame, destacando-se que na apreciação dos casos concretos os interesses superiores da criança podem orientar o caminho a ser adotado pelo julgador.

\footnotetext{
${ }^{144}$ WELTER, Belmiro Pedro. Investigação de paternidade sócioafetiva. Revista Brasileira de Direito de Família. Porto Alegre, Síntese/ IBDFAM, v. 6, p. 50-52, jul/ago/set. 2000.

${ }^{145}$ HERRERA, Marisa. Filiación, adoptión y distintas estructuras familiares em los albores del siglo XXI. In. DIAS, Maria Berenice e BASTOS, Eliene Ferreira. Família além dos mitos. Ed. Del Rey, Belo Horizonte, 2008, pág. 160: "tal como lo he adelantado, el derecho filial em sentido amplio presenta uma triple fuente: 1) la filiación biológica o por naturaleza - tal como reza el art. 240 del Código Civil Argentino, 2) la procreación humana asistida y 3) la filiación adoptiva. Estas três fuentes - com mayor o menor extensión interesan y repercuten sobre las distintas formas de organizaciona familiar."

${ }^{146}$ FACHIN, Luiz Edson. Comentários ao Novo Código Civil. Do Direito de Família. Do direito pessoal. Das Relações de Parentesco. Arts. 1.591 a 1.638. Vol. XVIII - Coord. Sávio de Figueiredo Feitosa -1 ${ }^{a}$ edição. Rio de Janeiro: Forense, 2003, pág. 64.
} 
O ilustre professor Paulo Luiz Netto Lôbo ${ }^{147}$, em artigo publicado nos Anais do IV Congresso Brasileiro de Direito de Família, muito bem observou que: "na tradição do Direito de Família brasileiro, o conflito entre a filiação biológica e a filiação sócio-afetiva sempre se resolveu em benefício da primeira. Em verdade, apenas recentemente a segunda passou a ser cogitada seriamente pelos juristas como categoria própria, merecedora de construção adequada. Em outras áreas do conhecimento, que têm a família como objeto de investigação, a exemplo da sociologia e da psicanálise, a relação entre pais e filhos fundada na afetividade sempre foi determinante para sua identificação".

$\mathrm{O}$ que se verificou, foi a insuficiência do critério genético para a determinação da paternidade. $\mathrm{O}$ conceito de paternidade afetiva, fundado na idéia de posse de estado de filho, veio então, equilibrar as verdades legal, biológica e social.

Felizmente, o reconhecimento absoluto da origem genética da pessoa como verdade do vínculo paterno-filial, tem perdido seu papel legitimador da filiação, sendo também valorizada a afetividade como meio de construção e reconhecimento da filiação, pelas razões que a seguir serão demonstradas.

\section{A PATERNIDADE E SEU CONTEÚdO AFETIVO. POSSE DE ESTADO DE FILHO.}

A Constituição Federal de 1988 foi realmente um marco no que diz respeito aos valores da família contemporânea brasileira. Iniciando pelo artigo $1^{\circ}$, inciso III, que traz o princípio da dignidade da pessoa humana como fundamento do Estado Democrático de Direito, aliado ao artigo $3^{\circ}$, inciso I, que consagra o princípio da solidariedade. Tais mudanças de paradigmas refletem diretamente na mudança das relações paterno-filiais, abrindo espaço para relações de igualdade, respeito mútuo e afeto, desligando-se das relações hierárquicas e patrimonializadas.

Esta alteração de perspectiva, especialmente, permite uma nova face da paternidade, a paternidade socioafetiva, na qual o vínculo que une pais e filhos é afetivo independentemente do vínculo ser biológico ou não.

\footnotetext{
${ }^{147}$ LOBO, Paulo Luiz Netto. Direito ao estado de filiação e direito à origem genética: uma distinção necessária. Anais do IV Congresso Brasileiro de Direito de Família, coord. Rodrigo da Cunha Pereira. Belo Horizonte, Del Rey, 2004.
} 
A posse do estado de filho traz para o Direito uma realidade social que, assim como o vínculo biológico, é apreensível no mundo dos fatos e indispensável para o estabelecimento de uma realidade jurídica da filiação fincada na verdade socioafetiva.

O estado de filiação deriva de origem biológica e não biológica, esta a orientação da Constituição Federal de 1988, como se depreende da análise dos artigos que tratam da matéria, artigo 227, $\S 6^{\circ}$ (todos os filhos são iguais, independentemente de sua origem), artigo 227, $\S \S 5^{\circ}$ e $6^{\circ}$ (adoção como escolha afetiva), artigo 227, caput (direito à convivência familiar) e artigos 229 e 230 (dever de solidariedade entre pais e filhos).

A Convenção sobre os direitos da criança - Assembléia Geral da ONU em 20/11/89, com força de lei no Brasil mediante o Decreto Legislativo n. 28 de 24/09/90 e do Decreto Executivo n. 99.710 de 21/11/91 - orienta que na solução de conflito deve-se aplicar o princípio do melhor interesse do filho.

O princípio do melhor interesse não é uma recomendação ética, mas diretriz determinante nas relações da criança e do adolescente com seus pais, com sua família, com a sociedade e com o Estado.

O princípio em questão impõe a predominância do interesse do filho. Desta forma, o julgador ante o caso concreto, deverá se nortear pelo princípio, decidindo se a realização pessoal do menor estará assegurada entre os pais biológicos ou entre os pais não biológicos. De toda forma, deve ser ponderada a convivência familiar, constituída da posse do estado de filiação, pois ela é prioridade absoluta da criança e do adolescente.

O Código Civil de 2002, seguindo a orientação constitucional, em seus dispositivos ampliou o conceito de paternidade e filiação, privilegiando a afetividade co mo nova forma de constituição familiar, como também podemos observar em seus dispositivos: artigo 1.593 (o parentesco é natural ou civil conforme resulte de consangüinidade ou outra origem), artigo 1.596 (igualdade dos filhos independentemente da origem), artigo 1.597 (presunção de paternidade na inseminação artificial heteróloga), artigo 1.605 (traz a idéia de posse de estado de filho - presunção de filiação).

A filiação é a relação de parentesco que se estabelece entre duas pessoas, uma das quais é considerada filha da outra (pai ou mãe).

Ensina o professor José Luiz Gavião de Almeida que "filiação é a relação de parentesco consangüíneo, em primeiro grau e em linha reta, que liga uma pessoa àquelas que a geraram. Desde a Antiguidade, a relação de filiação é o vínculo parental mais importante, talvez porque o mais próximo e também aquele que realmente sempre existiu. Com efeito, mesmo nas épocas em que não se poderia visualizar a existência de 
família como união entre o pai e a mãe, a relação de filiação era reconhecida, pelo que se pode considerar tal vínculo como o precursor das relações de parentesco." 148

A base ambivalente da filiação sugere a coincidência dos vetores socioafetivo e biológico no pai jurídico. Princípios e regras que se vertem em normas jurídicas estabelecem a paternidade, mediante tábua de valores que são incorporadas na legislação, na doutrina e na jurisprudência. ${ }^{149}$

O estado de filiação é a qualificação jurídica dessa relação de parentesco, atribuída a alguém, compreendendo um complexo de direitos e deveres reciprocamente considerados. O filho é titular do estado de filiação, da mesma forma que o pai e a mãe são titulares do estado de paternidade e maternidade.

O estado de filiação constitui-se por força de lei ou em razão da posse do estado, por força da convivência familiar, consolidada na afetividade. Nesse sentido, a filiação jurídica é sempre de natureza cultural, seja ela biológica ou não biológica.

Deste modo, explica Maria Christina Almeida: "pode-se ter uma paternidade jurídica sem ter a biológica, mas tendo a socioafetiva, pode existir a paternidade biológica sem existir a jurídica e a socioafetiva, pode-se, ainda, ter a paternidade socioafetiva, sem possuir a paternidade jurídica e a biológica." 150

Estabelece-se a posse do estado de filiação quando alguém assume o papel de filho perante aquele que assume o papel de pai, independentemente da existência do vínculo biológico entre eles. A posse do estado é a exteriorização da convivência familiar e do vínculo afetivo consolidado no ambiente familiar.

A posse de estado de filho, nestas circunstâncias, se destina a valorizar o elemento afetivo e sociológico da filiação. Trata-se de instrumento presente no ordenamento jurídico que possibilita o reconhecimento da filiação quando presentes elementos de fato que indiquem a formação de um vínculo de paternidade-filiação entre duas pessoas, ou seja, quando estabelecida uma relação psicoafetiva entre pai e filho quando o pai, além de emprestar seu nome de família, trata o filho como sendo verdadeiramente seu filho perante o ambiente social.

\footnotetext{
148 ALMEIDA, José Luiz Gavião. O Direito de Família e a Constituição de 1998. In Carlos Alberto Bittar (Org.). O Novo Estatuto da Filiação, São Paulo, Saraiva, 2003, pág. 154.

${ }^{149}$ FACHIN, Luiz Edson. Comentários ao Novo Código Civil. Do Direito de Família. Do direito pessoal. Das Relações de Parentesco. Arts. 1.591 a 1.638. Vol. XVIII - Coord. Sávio de Figueiredo Feitosa $-1^{a}$ edição. Rio de Janeiro: Forense, 2003, pág. 61.

${ }^{150}$ ALMEIDA, Maria Christina. A Paternidade Sócioafetiva e a Formação da Personalidade. O Estado e os Estados de Filiação. Revista Jurídica Del Rey, Belo Horizonte : Del Rey/IBDFAM, 2002, n. 8, p. 24, maio 2002. (Número especial).
} 
Maria Cláudia Crespo Brauner, por sua vez, afirma que a posse de estado de filho: "é aquela que se exterioriza pelos fatos, quando existem pais que assumem suas funções de educação e de proteção dos filhos, sem que a revelação do fator biológico da filiação seja primordial para que as pessoas aceitem e desempenhem a função de pai ou mãe."151

O estado de filiação estabelece-se, portanto, entre o filho e quem assumiu os deveres de paternidade e, é presumido em relação ao pai registral.

Existem alguns requisitos que nos auxiliam a identificar a posse do estado de filho, entre os quais o NOME - se o filho usa o nome de família; o TRATAMENTO - se dentro do lar, ou seja, na convivência familiar, é configurada a relação filho/pai, como se "realmente" fossem pai e filho; o RECONHECIMENTO PELA SOCIEDADE - se no ambiente social, há o reconhecimento pela sociedade da relação paterno/filial - ou seja, todos conhecem "Pedro" como filho de "Maria" e "João", por exemplo; e também quando uma AUTORIDADE PÚBLICA reconhece formalmente a relação paterno/filial, seja por meio de uma certidão ou uma decisão judicial.

Esta a lição de Luiz Edson Fachin, "uma conhecida trilogia clássica elenca os elementos que normalmente constituem a posse de estado de filho; nomen, tractus e fama. É sabido que estes são os principais dados formadores daquele conceito, mas, nem a doutrina, nem a jurisprudência, nem o legislador se arriscam em dar um rol completo ou definição acabada dos fatos aptos a constituí-lo. Assim vista, a posse de estado, é manifesta a sua natureza complexa. Não há dúvida que, formada por fatos, ela seja, num primeiro momento, um fato social do qual se extraem conseqüências jurídicas. Apresentando-se no universo dos fatos, a posse de estado de filho liga-se à finalidade de trazer para o mundo jurídico uma verdade social. Aproxima-se, assim, a regra jurídica da realidade." 152

Em regra, para a configuração da posse de estado de filho, necessária a presença dos requisitos da publicidade, continuidade. Contudo, a notoriedade da relação paterno-filial no ambiente social deve demonstrar estabilidade, ou seja, que o vínculo é contínuo e se constituiu há um determinado tempo para que não gere dúvidas o estabelecimento da posse de estado de filho.

151 BRAUNER, Maria Cláudia Crespo. Novos contornos do direito da filiação: a dimensão afetiva das relações parentais. In. Anuário do programa de pós-graduação em Direito. São Leopoldo. Unisinos, 2000. ${ }^{152}$ FACHIN, Luiz Edson. Estabelecimento da Filiação e Paternidade Presumida. Ed. Fabris, Porto Alegre, 1992, pág. 156/157. 
A posse de estado foi inserida no ordenamento (artigo 1.605 do Código Civil) como meio de possibilitar a prova da filiação quando inexistente o termo de nascimento. É dirigida, pois, tanto aos filhos biológicos quanto aos não biológicos.

A posse de estado exige além da aparência de filho, não basta o reconhecimento pelo meio social, necessário também o estabelecimento de tratamento e o reconhecimento das figuras de pai e filho nesta relação, dentro do ambiente familiar. Por isso a reunião dos três elementos clássicos (nomen, tractus, fama) começa a indicar a real existência desta relação de pai e filho, que, como dito, para poder ser afirmada com segurança, necessária a notoriedade da posse de estado de filho, que deve ser uma relação estável e contínua.

A relação paterno-filial, como se vê, não é plenamente estabelecida de pronto, necessita ser construída e solidificada, por aqueles que assumirem a função de pai e filho.

Ao dizer-se que a paternidade se constrói, toma lugar de vulto, na relação paterno-filial, uma verdade sócioafetiva, que, no plano jurídico, recupera a noção de posse de estado de filho. ${ }^{153}$

Ainda sob a égide do Código Civil de 1916, já anotava Maria Helena Diniz que: "Se em companhia do casal, há muito tempo vive um filho, ter-se-á, então, a posse do estado do filho e, nela baseada, a pessoa criada pelo casal poderá, apoiada em prova testemunhal, indicar em juízo o reconhecimento de sua filiação". ${ }^{154}$

Para Belmiro Pedro Welter, "não se pode edificar diferença jurídica entre o filho biológico (de direito) e o filho de criação (de fato), pois, em ambos os casos, são reconhecidos como filhos, vivendo em ambiente familiar que os acolheu gerando a posse de estado e constituindo, conforme João Baptista Villela, um nascimento emocional entre pais e filho. Não há diferença de criação, educação, destinação e carinho e amor entre filhos sociológicos e biológicos, não se podendo arquitetar conceitos jurídicos desiguais em relação a quem vive em igualdade de condições, sob pena de revisitar a odiosa discriminação entre os filhos, o que seria, sem dúvida, inconstitucional." 155

No Direito Brasileiro atual, com fundamento no artigo 227 da Constituição Federal e nos artigos 1.593, 1.596 e 1.597, considera-se estado de filiação

\footnotetext{
${ }^{153}$ FACHIN, Luiz Edson. Estabelecimento da Filiação e Paternidade Presumida. Ed. Fabris, Porto Alegre, 1992, pág. 23.

${ }^{154}$ DINIZ, Maria Helena. Código Civil Anotado, Ed. Saraiva, 1995, em nota I, ao artigo 349.

155 WELTER, Belmiro Pedro. Investigação de paternidade sócioafetiva. Revista Brasileira de Direito de Família. Porto Alegre, Síntese/ IBDFAM, v. 6, p. 50-52, jul/ago/set. 2000.
} 
decorrente da lei: filiação biológica - havida de relação de casamento ou união estável dos pais ou de único pai ou mãe, família monoparental-, filiação não biológica - oriunda da adoção regular e, filiação não biológica - pai que autorizou inseminação artificial heteróloga.

Lembramos que as duas últimas hipóteses - de filiação não biológica não são passíveis de arrependimento e, portanto, irreversíveis. Nessas hipóteses a convivência familiar e a afetividade são presumidas, ainda que de fato não ocorram.

Cumpre abrir um parêntese para tratar da idéia de 'adoção à brasileira', a qual se dá com a declaração falsa e consciente de paternidade e/ou maternidade, sem observância das exigências legais para a adoção. O declarante ou declarantes são movidos por intuito generoso e elevado de integrar a criança em sua família, como se a tivessem gerado.

Nessas hipóteses, ainda que de forma ilegal, atende-se ao princípio constitucional do artigo 227 da Constituição Federal, qual seja, assegurar à convivência familiar à criança e ao adolescente. Desta feita, ante o conflito de valores normativos o julgador deve sopesar os valores dentro do princípio da proporcionalidade.

E é esta orientação que vem sendo seguida pelo Superior Tribunal de Justiça, de priorizar a convivência familiar e os vínculos afetivos estabelecidos. ${ }^{156}$

Quanto ao tema, afirma Luiz Edson Fachin: "reconhecido o valor primordial do afeto no estabelecimento da filiação, emerge a conclusão acerca da veracidade do registro de nascimento que declare o que a manifestação fática da posse de estado de filho torna inequívoco. Quem detém posse de estado não detém mera aparência. A declaração no registro dessa realidade sociológica e afetiva nada mais é que natural conseqüência do necessário reconhecimento dessa ordem de idéias. (...) Daí porque, nasce a distinção entre ascendente genético e pai, eis que a paternidade é um conceito jurídico,

156 "RECURSO ESPECIAL - AÇÃO DECLARATÓRIA DE NULIDADE DE REGISTRO CIVIL NEGATIVA DE PRESTAÇÃO JURISDICIONAL - ALEGAÇÃO DE VIOLAÇÃO GENÉRICA RECURSO ESPECIAL, NO PONTO, DEFICIENTEMENTE FUNDAMENTADO - APLICAÇÃO DA SÚMULA N. 284/STF - ADOÇÃO À BRASILEIRA - PATERNIDADE SÓCIO-AFETIVA IMPOSSIBILIDADE, NA ESPÉCIE DE DESFAZIMENTO - RECURSO ESPECIAL IMPROVIDO.

1. O conhecimento do recurso especial exige a clara indicação do dispositivo, em tese, violado, bem assim em que medida o aresto a quo teria contrariado lei federal, o que in casu não ocorreu com relação à pretensa ofensa ao artigo 535 do Código de processo Civil (Súmula n. 284/STF).

2. Em se tratando de adoção à brasileira, a melhor solução consiste em só permitir que o pai-adotante busque a nulidade do registro de nascimento, quando ainda não tiver sido constituído o vínculo de sócioafetividade com o adotado.

3. Recurso especial improvido.

(Superior Tribunal de Justiça. REsp 1088157/PB. Recurso Especial $n^{\circ}$ 2008/0199564-3, rel. Ministro Massami Uyeda, Terceira Turma, j. 23/06/2009, publicado DJE 04/08/2009). 
enquanto que a ascendência é uma definição técnica que pode subsidiar, de modo não absolutamente vinculante, o resultado jurídico." 157

Ademais, acreditamos que a invalidade do registro não pode ser considerada quando atingido o estado de filiação, por longos anos, estabilizado na convivência familiar.

Neste sentido, julgado do Tribunal de Justiça de São Paulo, proferido nos autos da apelação no 218.764-4/5, pelo D. Desembargador Enio Santarelli Zuliani, que entende pela irrevogabilidade do ato, em favor da manutenção da filiação, em prol do menor e de sua dignidade, quando o adulto que assumiu a paternidade do filho de sua companheira, deseja anular o ato em razão do fim do relacionamento.. ${ }^{158}$

Adequada e digna de aplauso a decisão do Tribunal de Justiça de São Paulo. Estatui o Código Civil brasileiro a irrevogabilidade do reconhecimento, por certo, o que ingressou nesse mundo jurídico pela força jurígena da declaração não pode, no caso, ser desdito pelo declarante. Assenta-se, pois, numa idéia de estabilidade vinculada à proteção do sentido familiar.

Outro exemplo é o julgado do Tribunal de Justiça do Rio de Janeiro, que demonstra a adequada aplicação do artigo 1.604 do Código Civil, reconhecendo a prevalência da vontade de criar vínculo de parentesco com determinada pessoa registrada como se fosse sua filha, estabelecido durante 50 anos, à formalidade do procedimento. Estabelecida a posse de estado de filho, entendeu o julgador não ser possível a anulação do registro pela mãe sob a alegação de não ter anuído. ${ }^{159}$. Eis aí exemplar e elogiável decisão, pautada nesta nova direção.

${ }^{157}$ FACHIN, Luiz Edson. Comentários ao Novo Código Civil. Do Direito de Família. Do direito pessoal. Das Relações de Parentesco. Arts. 1.591 a 1.638. Vol. XVIII - Coord. Sávio de Figueiredo Feitosa $-1^{a}$ edição. Rio de Janeiro: Forense, 2003, pág. 112.

158 "A adoção à brasileira, ou o reconhecimento voluntário de filho de companheira, cria ato irrevogável (art. $1^{\circ}$, da Lei ${ }^{\circ} 8.560 / 92$ e art. 357 do CC) para personificação do direito ao nome e condição social da criança, fator de dignidade humana (art. $1^{\circ}$, III, da CF), preponderantemente ao desejo de retaliação pelo fim de relacionamento dos adultos; quanto à falsidade do registro, causa de nulidade prevista no art. 348 do CC, não poderia o modernizado Direito de Família penalizar o inocente quando o próprio agente causador da fraude recebe indulgência criminal (art. 242, parágrafo único do CP)'”Tribunal de Justiça de São Paulo - Apelação Cível no 218.764-4/5, $3^{\text {a }}$ Câmara de Direito Privado, rel. Des. Ênio Santarelli Zuliani - j. 19/02/2002.

159 "Se a autora e seu companheiro resolveram criar a ré como filha, desde alguns meses de nascida, e o varão a registrou, depois de 12 anos, atribuindo a paternidade a si mesmo e a maternidade à autora, no tipo de procedimento conhecido como adoção à brasileira não é admissível que, passados mais de 50 anos, venha a autora propor essa ação de anulação do ato ao argumento de que não anuiu com o mesmo, tanto que o desconhecia. Se a declaração foi, como se alega, inverídica em relação ao fato da geração, não o foi quanto à manifestação da vontade de criar com a pessoa registrada um vínculo de parentesco, que é, no caso, o parentesco civil de fato, cuja natureza nem mesmo a inobservância dos ritos legais poderia descaracterizar’Tribunal de Justiça do Rio de Janeiro - Apelação Cível nº 1999.001.08518 - 14ª C.Cív. Rel. Des. Mauro Fonseca Pinto Nogueira - DORJ 27.04.2000 
A posse de estado revela o modo de perceber as relações de filiação, assim, atribui sensibilidade jurídica a determinados fatos sociais, valorizando elementos e situações na busca do verdadeiro significado de família

Assevera Luiz Edson Fachin que "no fundamento da posse de estado de filho é possível encontrar a verdadeira paternidade, que reside antes no serviço e no amor que na procriação. Esse sentido da paternidade faz eco no estabelecimento da filiação, e por isso, reproduzindo a modelar frase do professor João Batista Villela, é possível dizer que, nesse contexto, há um nascimento fisiológico e, por assim dizer, um nascimento emocional" $" 160$.

Sobre o tema, justificando a impossibilidade de investigação de paternidade biológica, nos casos em que configurada a paternidade afetiva, assevera Zeno Veloso "priorizando-se os interesses da criança, o biologismo é contido quando se constata a posse do estado de filho diante do marido da mãe. Se coexistem a paternidade jurídica (estabelecida pela regra 'pater is est') é a paternidade afetiva, esta situação real e concreta em que se encontra o filho na família e na sociedade é barreira intransponível para que se introduza um questionamento nesta relação paterno-filial. A busca da verdade biológica, obviamente, tem de ter alguns limites, inclusive para garantir o que seja mais útil para a criança, para seu equilíbrio psicológico, sua paz, tranqüilidade, enfim, para sua felicidade". ${ }^{161}$

O jurista português Guilherme de Oliveira, quanto à adoção do critério de posse de estado de filho como elemento para o reconhecimento da filiação, registra que: "Ninguém estranharia que o conceito de posse de estado ganhasse um conteúdo particular e dirigido à finalidade de que se trata. Em vez de índice de filiação biológica ela serviria para consolidar um vínculo meramente afectivo, sociológico, para exprimir a criação de uma família cuja estabilidade a lei resolveria proteger no interesse do filho e no interesse social" 162

A posse de estado, como realidade sociológica e afetiva, pode se mostrar tanto em situações em que está presente a filiação biológica, como naquelas em que a vontade e o afeto são os únicos elementos - do que o exemplo mais evidente é o da adoção, ato puramente voluntário, que tem no afeto sua dimensão central, à margem da biologia. Outro exemplo que a evolução da engenharia genética traz é o do homem que

${ }^{160}$ FACHIN, Luiz Edson. Estabelecimento da Filiação e Paternidade Presumida. Ed. Fabris, Porto Alegre, 1992, pág. 163

${ }^{161}$ VELOSO, Zeno. Direito brasileiro da filiação e paternidade. Ed. Malheiros, 1997, pág. 214.

${ }^{162}$ OLIVEIRA, Guilherme. Critério Jurídico da Paternidade. Coimbra: Almedina, 2003, pág. 445. 
registra como seu o filho gerado artificialmente por sua esposa, com material genético de outrem.

Pois bem, a posse do estado de filho foi a forma encontrada no ordenamento para se dar guarida à intenção de valorizar o elemento afetivo da filiação. É um recurso útil para atingir tal finalidade, eleita como essencial no estabelecimento do verdadeiro sentido da filiação, cumprindo os princípios atuais nos quais se baseiam a paternidade. É a posse de estado, enquanto meio de prova do estado de filiação, fundamento legal para a filiação afetiva.

\section{PATERNIDADE. CONCEITO CONTEMPORÂNEO.}

A paternidade é múnus. É um direito-dever, construída na relação afetiva e que assume os deveres de realização dos direitos fundamentais da pessoa em sua formação (art. 227 CF): vida, educação, lazer, profissionalização, cultura, dignidade, respeito, liberdade, convivência familiar. É pai quem assumiu esses deveres, ainda que não seja o genitor.

Nestas circunstâncias, a função exercida por aquele que assumiu o papel de pai é muito mais importante, no estabelecimento do vínculo paterno-filial, que a do genitor, enquanto doador de material genético. É a função assumida que determina o papel de cada um dentro do ambiente familiar.

Rodrigo da Cunha Pereira, para verificar qual o significado e importância de um pai em outras culturas e ordenamentos jurídicos, narra que: "Levi Strauss, em 'As Estruturas Elementares do Parentesco', demonstrou que a família tem inúmeras facetas em relação ao papel de pai. Em algumas sociedades, o marido tem apenas um papel social e econômico. Em outras, é o pai legal quem educa e ama os filhos de uma mulher com quem vive, mesmo sabendo que não é o pai biológico. Em uma sociedade do Tibet, por exemplo, vários irmãos partilham de uma mesma mulher, e o pai é o pai legal, isto é, aquele que cumpriu uma cerimônia especial até que outro resolva assumir o direito de paternidade. Entre os nayars (Índia), as crianças pertencem somente à linhagem materna, e o marido é absolutamente insignificante. Na Austrália, uma tribo da costa nordeste chamada Wik Mokans tem clara a distinção entre paternidade biológica e paternidade social e possui palavras diferentes para designar as diferentes paternidades. Na Índia central, os nayars, o esposo ritual (pater) e os amantes (os genitores) dividem entre si o papel que entre nós é atribuído a um único homem. Em várias tribos africanas, a paternidade é associada 
simbolicamente ao avô, pois acreditam que as crianças são a reencarnação do avô ou bisavô". 163

Pois bem, como podemos observar, é a vontade de ser pai e a assunção de responsabilidade que torna possível o estabelecimento da verdadeira paternidade. Assim, ela pode coincidir, ou não, com o elemento biológico.

A idéia de "posse de estado" ampliou o conceito de paternidade e permitiu a aproximação da idéia de paternidade a de uma função, assim como considerado pela Psicanálise, associada ou não à paternidade biológica.

Essa função paterna exercida por "um" pai que é referência ao filho e fundamental na sua estruturação enquanto pessoa. Pode tal função ser exercida por uma série de pessoas, o genitor, o marido da mãe, o avô, um tio, ou simplesmente por aquele que criou e o acolheu como filho.

Segundo uma visão psicanalítica, o pai é uma função simbólica, já que qualquer um pode exercer tal função. Não obstante o seu lugar é essencial como estruturante na formação psíquica dos filhos - um terceiro na relação mãe-filho. É exatamente este terceiro que vem separar a mãe do filho, possibilitando que ele se torne sujeito. Foi essa necessidade, essa essencialidade que Freud demonstrou ao mundo, através da lenda grega de Édipo, teorizando o seu Complexo de Édipo, em que o desejo da criança pela mãe deve ser interditado por um terceiro. É este terceiro que metaforiza e exerce a função paterna.

Na doutrina, predomina a orientação de que pai não é apenas aquele que empresta sua colaboração genética na geração da criança. A relação paterno-filial que identifica pais e filhos é aquela construída no cotidiano, com base no afeto, na dedicação, na educação, proteção, orientação, nos cuidados despendidos, enfim, pai é aquele que se dedica para o pleno desenvolvimento de seu filho.

Para Eduardo de Oliveira Leite: “a verdadeira filiação - esta a mais moderna tendência do direito internacional - só pode vingar no terreno da afetividade, da intensidade das relações que unem pais e filhos independente da origem biológica genética"164.

João Batista Villela ensina que “a paternidade em si mesma não é um fato da natureza, mas um fato cultural. Embora a coabitação sexual, de que possa resultar

\footnotetext{
163 PEREIRA, Rodrigo da Cunha. Direito de Família: uma abordagem psicanalítica. Belo Horizonte, Del Rey, 1997, pág. 132/134.

164 In. Direito brasileiro da filiação e paternidade. Zeno Veloso. Ed. Malheiros, 1997, pág. 123.
} 
gravidez, seja fonte de responsabilidade civil, a paternidade, enquanto tal, só nasce de uma decisão espontânea. Tanto no registro histórico, como no tendencial, a paternidade reside antes no serviço e no amor que na procriação. As transformações mais recentes por que passou a família, deixando de ser unidade de caráter econômico, social e religioso para se afirmar fundamentalmente como grupo de afetividade e companheirismo, imprimiram considerável reforço ao esvaziamento biológico da paternidade. $\mathrm{Na}$ adoção, pelo seu conteúdo eletivo, tem-se a prefigura da paternidade no futuro, que radica essencialmente idéia de liberdade." 165

É pai aquele que ama e cria uma criança. Aquele que educa, orienta, ensina, se dedica, repreende, protege, alimenta, veste. Ainda que tal função seja exercida de fato, esta pessoa, sem dúvida, pode ser considerada como pai. Existe nesta relação uma realidade afetiva que o direito deve enxergar e amparar. A pessoa que assume a função de pai tem direitos e deveres para com a criança, sempre, buscando o seu melhor interesse.

Pois bem, a filiação biológica, por si só, não é garantia da vivência da paternidade, a verdade biológica é insuficiente para determinação da paternidade, eis que, como visto, a paternidade envolve a construção de uma relação e o fortalecimento de um vínculo, fato que se dá, no dia a dia,

Reforçando este conceito contemporâneo de paternidade, sensivelmente, o professor José Fernando Simão ${ }^{166}$ nos ensina que "pai não é, necessariamente, o doador de material genético, mas sim aquele que cria, cuida, ama e se preocupa, perdendo noites de sono com as doenças dos filhos, chorando com seus sucessos e conquistas e esperando, quem sabe um dia, que em sua velhice, ocorra a retribuição".

De fato, o elo de união entre pai e filho se fortifica e se estabelece no trato diário, na convivência, quando é possível vivenciar e sedimentar o mais nobre dos sentimentos o amor.

Anota Pietro Pierlingieri: “o sangue e os afetos são razões autônomas de justificação para o momento constitutivo da família, mas o perfil consensual e a affectio constante e espontânea exercem cada vez mais o papel de denominador comum de qualquer núcleo familiar". Vê-se, pois, como se acentua na melhor doutrina, a ausência de exclusividade na fundação consangüínea da família. Não trata (e nem poderia ser) da

\footnotetext{
165 VILLELA. João Baptista. Desbiologização da Paternidade. Revista Forense, jul-ago-set 1980, p. 45.

166 SIMÃO, José Fernando. O valor jurídico do afeto: a arte imita a vida A parentalidade socioafetiva e a novela. Publicado no site www.flaviotartuce.adv.br
} 
exclusão do iure sanguinis, e sim, de um equilíbrio diante da ratio da comunhão de vida." 167

Embora não seja imprescindível o chamamento de filho, os cuidados na alimentação e na instrução, o carinho no tratamento (quer em público, quer na intimidade do lar) revelam no comportamento a base da paternidade. Apresenta-se então a paternidade como aquela que, fruto do nascimento mais emocional e menos fisiológico, "reside antes no serviço e amor que na procriação. ${ }^{168}$

A verdade biológica nem sempre é a verdade da filiação. Neste passo, o direito, ao reconhecer a filiação jurídica com base em outros elementos, que não exclusivamente o biológico, mostrou um grande avanço. Isto porque, como até então visto, a verdade da filiação se dá no âmbito cultural, social e afetivo, onde a relação paterno-filial é efetivamente construída.

O estado de filiação desligou-se da origem biológica e da filiação legítima, para assumir dimensão mais ampla que abranja aquela e qualquer outra origem. $\mathrm{O}$ estado de filiação certamente engloba a filiação biológica e a filiação não biológica.

O estado de filiação de cada pessoa humana é único e de natureza sócioafetiva, desenvolvido na convivência familiar, derivando ou não biologicamente dos pais. Para ser pai, é preciso primeiro fazer-se pai. É necessário dedicar-se à construção cotidiana de paternidade.

Para Paulo Luiz Netto Lôbo, “o estado de filiação é gênero, do qual são espécies a filiação biológica e a filiação não biológica. Ainda que ele derive, na grande maioria dos casos, do fato biológico, por força da natureza humana, outros fatos o determinam, a saber, a adoção, a posse do estado de filiação e a inseminação artificial heteróloga. Assim, para abranger todo universo de situações existenciais reconhecidas pelo direito, o estado de filiação tem necessariamente natureza cultural (ou socioafetiva)." 169

Dúvidas não restam mais que genitor é quem gera e pai é quem cria. A paternidade envolve a constituição de valores, educação e formação do filho, de sua individualidade e dignidade - estes adquiridos principalmente na convivência familiar.

\footnotetext{
${ }^{167}$ PERLINGIERI, Pietro. Perfis do direito civil: introdução ao direito civil constitucional, Rio de Janeiro, renovar, 1997, p. 244.

${ }^{168}$ FACHIN, Luiz Edson. A tríplice paternidade dos filhos imaginários. ALVIM. Teresa Arruda (coord.). Repertório de Jurisprudência e Doutrina sobre Direito de Família: Aspectos constitucionais, civis e processuais. São Paulo. Revista dos Tribunais, 1998, v. 02, pág. 178/179..

169 LÔBO, Paulo Luiz Netto. Direito ao estado de filiação e direito à origem genética: uma distinção necessária. Texto extraído do site Jus Navegandi - HTTP://jus2.uol.com.br/doutrina/texto.asp?id=4752
} 
Hoje em dia é cada vez mais comum a identificação da filiação pelo afeto, tanto que este tema é constantemente tratado na mídia, seja através de novelas, seriados e filmes, refletindo, certamente os fatos sociais. E primordialmente, o tema, também, tem sido muito abordado em nossos Tribunais, que, em linha com a nossa melhor doutrina, tem reconhecido o afeto como base do estado de filiação.

\section{PATERNIDADE SOCIOAFETIVA. RECONHECIMENTO E JUSTIFICATIVAS.}

O Direito em muito avançou na questão do estabelecimento da paternidade. O reconhecimento da igualdade entre os filhos, independente de sua origem, coma vedação constitucional de discriminação dos filhos outrora ilegítimos, o reconhecimento da filiação biológica com base no desenvolvimento científico, atenuando a presunção pater is est, são alguns dos exemplos da evolução nesta área. Mas, sobretudo, não há como deixar de mencionar, a incorporação do elemento social e afetivo, como base para o estabelecimento da filiação. Percebeu-se que, sendo a paternidade um conceito jurídico, o elemento biológico não poderia ser o único a ser levado em consideração, pois, é a paternidade a expressão jurídica de uma verdade socioafetiva.

A convivência familiar independe da origem do filho e promove a integração definitiva no grupo social familiar, bem como, a relação afetiva tecida no tempo entre quem convive. Configurada a posse do estado de filho (nome, tratamento e reconhecimento pela sociedade), há elementos para que se reconheça a paternidade afetiva.

A perspectiva da filiação apresenta novos horizontes em sua base socioafetiva.

Neste contexto, Rodrigo da Cunha Pereira, questiona: "Para o Direito, pai é aquele que empresta seu nome na certidão de nascimento do filho (...). Mas será que o ordenamento jurídico, tão vinculado a elementos biológicos para a paternidade, pode garantir ou ajudar a garantir o estabelecimento da paternidade? Podemos definir o pai como o genitor, o marido ou companheiro da mãe, ou aquele que cria os filhos e asseguralhes o sustento, ou é aquele que dá sobrenome ou mesmo o seu nome?" E então, com base nos princípios trazidos pelo Estatuto da Criança e do Adolescente, especialmente, na idéia de pais sociais, afirma: "É na compreensão do papel social do pai e da mãe, desprendendose do fator meramente biológico, que esse estatuto vem ampliar o conceito de pai, realçando sua função social. Podemos notar, aí, o avanço e um sinal de compreensão, pelo 
nosso ordenamento jurídico, de que o pai é muito mais importante como função do que propriamente como o genitor". 170

No ordenamento jurídico brasileiro não há previsão legal que reconheça expressamente a paternidade afetiva, para tanto, é necessário utilizar os princípios constitucionais fundamentais. Entretanto tal previsão seria imprescindível uma vez que a verdadeira filiação só pode vingar no terreno da afetividade.

O Direito deve traduzir a realidade social, acompanhando as transformações oriundas da vida, sendo capaz de absorver as necessidades da sociedade, para assim, poder ampará-la, nas mais diversas formas de agrupamento social.

Atualmente, como até então visto, é certo que as famílias se sustentam muito mais pelo afeto do que por necessidades reprodutivas ou econômicas. Assim, primordial a verificação do afeto na relação paterno-filial para o estabelecimento da filiação. A carga genética do filho não basta para que o pai afetivo deixe de ser pai. Importante ressaltar que o reconhecimento da paternidade afetiva é possível ainda que o filho tenha sido registrado pelo pai biológico.

O fato a ser considerado pelo Direito para reconhecimento da relação paterno-filial não constitui apenas um fato biológico, mas, também, um fato social, que se revela tanto na sua manifestação perante o grupo social, como, especialmente, na esfera psicológica e afetiva dos sujeitos.

Diz Gerard Cornu que a verdade biológica não reina absoluta sobre o direito da filiação, porque esta incorpora, necessariamente, um conjunto de outros interesses e valores. Para o autor, confundir verdade real da filiação com verdade biológica, é um entendimento "reducionista, cego, demagógico e decepcionante", concebendo "um direito biológico totalitário, além de um pseudo-direito subjetivo ilusório e nefasto". 171

Aponta Luiz Edson Fachin que "paternidade e ascendência genética são conceitos que nem sempre se identificam no mesmo sujeito. (...) "São aí compreendidas novas tendências do direito de filiação no direito contemporâneo de família. Hoje se tem uma certa radiografia do modelo jurídico da filiação e da família, que apanha a "constitucionalização" da filiação e a superação do sistema clássico da filiação originário do Código Civil brasileiro, e alcança o transcurso da Natureza à engenharia genética. A

\footnotetext{
${ }^{170}$ PEREIRA, Rodrigo da Cunha. Direito de Família: uma abordagem psicanalítica. Belo Horizonte, Del Rey, 1997, pág.131/132.

${ }^{171}$ CORNU, Gerard. Droit Civil: La Famille. 8aédition. Paris, Montchestien, 2003, pág. 324/326.
} 
voz do sangue está posta no código genético; a voz do coração pode estar exposta na apreensão jurídica do liame socioafetivo. Equilibra-se a paternidade entre o dado e o construído, ou, como prefere João Batista Vilela, entre o fato e a norma." 172

Na dissociação do conceito de paternidade de origem biológica, José de Oliveira Ascensão ensina que: "A quebra é de conceito, mas é mais: é também de percepção e da construção da própria realidade. É que “a ordem jurídica não é uma estrutura estática e acabada, mas uma ordem evolutiva, uma resposta diferente a cada nova situação a cada nova situação social". ${ }^{173}$

Por sua vez, assevera Heloisa Helena Barboza que: “A determinação da paternidade com base na informação genética tornou-se, porém, um imperativo, como se bastasse o vínculo biológico para criar talvez a mais importante das relações humanas: a de filiação. Não há que se confundir identidade genética com paternidade/maternidade. $\mathrm{O}$ ideal é que exista a coincidência entre ambas, mas a paternidade/maternidade é construída, antes de mais nada, com afeto, que jamais se detectará em uma lâmina de laboratório". ${ }^{174}$

A filiação como fato cultural se constrói, logo a verdade sociológica só identificará a relação paterno-filial, enquanto fruto do afeto e da convivência. Essa dimensão da relação paterno-filial não se explica apenas na descendência genética, ainda, que o ideal seja a coincidência entre ambas.

O desenvolvimento da engenharia genética que tornou certa a verdade biológica da filiação, também trouxe um elemento afetivo com o desenvolvimento das técnicas de inseminação artificial heteróloga. Assim, se, de um lado, a ciência permite a certeza sobre os laços de sangue, ela admite, sob outro aspecto, que tais laços sejam postos à margem diante de uma realidade afetiva, impondo, pois, o reconhecimento de uma filiação socioafetiva.

Eduardo de Oliveira Leite assim descreve tal fato: "as procriações artificiais e todos os efeitos daí decorrentes alteraram, porém, a ordem natural da evolução e, negando uma tradição assentada (da verdade biológica) propõe o contrário. Negligenciando as conquistas obtidas pela verdade genética, os promotores das inseminações ou das fecundações, das doações de gametas, pregam a desconsideração de

\footnotetext{
${ }^{172}$ FACHIN, Luiz Edson. Comentários ao Novo Código Civil. Do Direito de Família. Do direito pessoal. Das Relações de Parentesco. Arts. 1.591 a 1.638. Vol. XVIII - Coord. Sávio de Figueiredo Feitosa -1 ${ }^{a}$ edição. Rio de Janeiro: Forense, 2003, pág. 57/58.

${ }^{173}$ ASCENSÃO, José de Oliveira. O Direito: introdução e teoria geral. Uma perspectiva luso-brasileira, Lisboa. Calouste Gulbenkian, 1978, p. 504.

${ }^{174}$ BARBOZA, Heloisa Helena, O reconhecimento jurídico. Del Rey. Revista jurídica, a 4, n. 8, p. 23, maio 2002.
} 
tão-só verdade biológica em proveito de uma verdade afetiva." Não se trata, necessariamente, de um juízo de exclusão, e sim de complementaridade.” 175

A paternidade é antes de tudo, uma opção do ser humano. Não estamos dizendo da procriação, fenômeno natural, instintivo desde os primórdios, sobre o qual o homem, ainda nos dias de hoje, ante toda a informação à disposição, ainda gera filhos sem ter a intenção de ser pai. Somente com o nascimento, se estabelecerá efetivamente a relação paterno-filial e, pai, será aquele que assumir a função de pai. É, pois, uma opção assumir ou não integralmente o papel de pai .

Neste sentido, preciosa a lição de João Batista Vilella,: "Note-se, entretanto, que a paternidade, em si mesma, não é um fato da natureza, mas um fato cultural. Aqui, o fato da natureza é dado por uma relação de causalidade material: a fecundação e seus necessários desdobramentos. É bem verdade que este fato enquanto tal, não está subtraído à vontade humana, que decide, afinal, de sua ocorrência ou não. Tanto mais evidente se torna assim, de resto, a linha demarcatória entre o que é fato do homem e o que é fato da natureza. $\mathrm{O}$ homem tem o poder de pôr em ação mecanismos da natureza de que decorre o nascimento de uma pessoa. Ou abster-se de fazê-lo. E, diante do nascimento da pessoa, tem de novo o poder de comportar-se em relação a ela por vários modos, que vão desde o seu mais radical acolhimento à sua absoluta rejeição. Insista-se, porém: a linha de fenômenos que vai desde a concepção até o nascimento não tem característica propriamente humana, no rigoroso sentido do termo, isto é, não constitui manifestação de liberdade." 176

Logo, quando assumida a função de pai, estabelecido o vínculo entre pai e filho, a verdade socioafetiva da filiação torna-se até mais relevante que a verdade biológica. A verdadeira relação de paternidade/filiação não está apenas nos laços biológicos, mas na realidade de afeto que une pais e filhos, e se manifesta perante o grupo social e à família.

A realidade jurídica da filiação deve, então, se revelar na verdade socioafetiva da filiação, tendo como base, a posse do estado de filho, que possui os elementos necessários ao reconhecimento da relação de filiação.

Afirma Luiz Edson Fachin: "Se não há dúvida acerca da relevância do reconhecimento dos laços biológicos da filiação, o vínculo que une pais e filhos, e que lhes oferece tais qualificações, é mais amplo que a carga genética de cada um: diz respeito às

\footnotetext{
${ }^{175}$ LEITE, Eduardo de Oliveira. Temas de direito de família, pág. 121.

${ }^{176}$ VILLELA. João Baptista. Desbiologização da Paternidade. Revista Forense, jul-ago-set 1980, p. 45.
} 
relações concretas entre eles, o carinho dispensado, o tratamento afetuoso, a vontade paterna em se projetar em outra pessoa, a quem reconhece como filho, não só em virtude do sangue, mas em virtude do afeto, construído nas relações intersubjetivas concretas.". ${ }^{177}$

A independência entre a verdade biológica e a paternidade, não é novidade para o Direito. São inúmeras as situações previstas no ordenamento nas quais a relação paterno-filial se dá entre pessoas sem qualquer vínculo biológico, e, tem como base, a expressão pura do afeto, sendo, a adoção e a inseminação artificial heteróloga, os exemplos mais expressivos, posto que, por excelência, uma paternidade baseada na escolha de ser pai ou mãe, de criar e educar uma criança, por amor, ou seja, o puro exercício da liberdade.

A relação paterno-filial, portanto, se constrói, em sua essência, do afeto que une pai e filho, independente do vínculo biológico ente eles. Sendo outro exemplo clássico da filiação fundada no afeto e na vontade de assumir o papel de pai o instituto da adoção, presente, há muito, no nosso ordenamento.

A adoção constitui espaço em que a verdade socioafetiva da filiação se manifesta com ênfase inegável. Mais do que os laços de sangue, o que une o adotante e o adotado são os laços de afeto, que se constroem no espaço de convivência familiar.

No mesmo sentido a lição de Goldstein, Anna Freud e Solnit, explicando que a identificação dos pais pelas crianças se dá em virtude de seu comportamento, ou seja, da postura que assumiram em relação àquela criança, despendendo os cuidados necessários para o seu desenvolvimento como ser humano, assim, citada por João Batista Villela: "para a criança mesma os fatos físicos da geração e parto não conduzem diretamente a um vínculo com os pais. Suas relações de sentimento surgem com base na satisfação de suas necessidades por alimento, cuidados, simpatia e estímulos. Somente quando são os próprios pais biológicos que atendem a esses desejos, a relação biológica determina uma psicológica, na qual a criança possa se sentir mais segura, apreciada e desejada”. E arrematam categóricos: "Pais biológicos que não estabelecem esse vínculo ou que não vivem em comunidade com a criança são, para os sentimentos desta, nada mais que estranhos". ${ }^{178}$

\footnotetext{
${ }^{177}$ FACHIN, Luiz Edson. Comentários ao Novo Código Civil. Do Direito de Família. Do direito pessoal. Das Relações de Parentesco. Arts. 1.591 a 1.638. Vol. XVIII - Coord. Sávio de Figueiredo Feitosa -1ª edição. Rio de Janeiro: Forense, 2003, pág. 28/29.

${ }^{178}$ VILLELA. João Baptista. Desbiologização da Paternidade. Revista Forense, jul-ago-set 1980, p. 50.
} 
A mais bonita e relevante das provas do estabelecimento desta relação, quando construída apenas com base no afeto, é quando se verifica o chamamento de filho e a aceitação do chamamento de pai.

De fato, de extrema relevância a identificação do afeto na família. Só com a realização da afetividade dentro do grupo familiar que será possível o desenvolvimento da solidariedade entre os participantes. Essencial para a harmonia do grupo e para a formação de cada um como cidadão.

Contudo, como visto, não há no ordenamento jurídico brasileiro dispositivo expresso que reconheça a verdade sócioafetiva como elemento constitutivo da filiação, todavia, os princípios constitucionais, especialmente o da dignidade da pessoa humana, do melhor interesse do menor e da afetividade, permitem o reconhecimento da filiação sócio-afetiva. Neste sentido, a conclusão de Belmiro Pedro Welter: "Conclui-se, pois, que, embora o País tenha canonizado a filiação biológica, deve ser reconhecida, em ação de investigação de paternidade, a perfilhação sócio-afetiva, porque: a) a Carta Magna proíbe qualquer discriminação entre filhos, não afastando, a toda evidência, o filho de direito ou de fato; b) a Constituição Federal determina sejam cumpridos os princípios da dignidade humana e da cidadania, elevados à categoria de fundamento da República artigo $1^{\circ}$, incisos II e III); c) deve ser observado o princípio da prevalência dos interesses do menor, cujo reconhecimento da filiação (biológica e sociológica) é direito personalíssimo, indisponível e imprescritível, podendo ser exercitado contra os pais ou seus herdeiros, sem qualquer restrição (artigo 27 do ECA)" ${ }^{\text {179. }}$

Observa-se, pois, que a adoção da idéia de desbiologizar a paternidade traz significativa mudança para o conceito das relações paterno-filiais, pois, pais, serão aqueles que conscientemente optarem pelo livre exercício da paternidade.

A família não deve estar submergida nos limitados propósitos da família biológica normatizada, isso porque a verdadeira família não é decorrente de fornecimento de material genético, mas, sim, dos laços afetivos familiares, decorrentes do amor e do carinho e da solidariedade, assim, deve ser compreendida pela circunstancia de ser-pai, de ser-filho, de ser-irmão, de ser-marido, de ser-convivente, de ser-família.

Afirma Luiz Edson Fachin: "A verdade sociológica da filiação se constrói, revelando-se não apenas na descendência, mas no comportamento de quem expende cuidados, carinho no tratamento, quer em público, quer na intimidade do lar, com

${ }^{179}$ WELTER, Belmiro Pedro. Investigação de paternidade sócioafetiva. Revista Brasileira de Direito de Família. Porto Alegre, Síntese/ IBDFAM, v. 6, p. 50-52, jul/ago/set. 2000. 
afeto verdadeiramente paternal, construindo vínculo que extrapola o laço biológico, compondo a base da paternidade. É à luz de uma hermenêutica constitucional de valorização da dignidade da pessoa humana - princípio fundante da república, conforme se extrai do art. 1 da Carta Magna”. ${ }^{180}$

Neste contexto, não há mais como prevalecer as antigas motivações que determinavam o estabelecimento da paternidade, fundada na família matrimonializada, na legitimidade da filiação, no interesse dos pai com base na paz doméstica. No atual estágio de evolução das relações familiares, não há mais como confundir estado de filiação e origem biológica, este último, não mais pode ser determinante para o estabelecimento do primeiro.

Não há qualquer fundamento jurídico para que se enalteça a origem biológica da filiação. A Constituição Federal estabelece exatamente o contrário, abrigando gênero somente o estado de filiação de qualquer natureza, sem primazia de um sobre o outro.

Como disse Maria Christina de Almeida: “A paternidade passa a receber um conceito flexível e instrumental, tendo em mira o elo substancial de pelo menos um dos genitores com seus filhos, que poderá ter origem não apenas no casamento. Mas, sim, inteiramente atenta à qualidade da entidade familiar como núcleo voltado, precipuamente, à realização espiritual e ao desenvolvimento da personalidade de seus membros." 181

Em havendo um conflito entre pais biológicos e pais não biológicos, hoje, ante as novas diretrizes constitucionais, tal conflito não mais se resolve pela primazia dos primeiros ou dos segundos. Mudou o foco dos interesses dos pais para os filhos. A Convenção Internacional dos Direitos da Criança, de 1989, com força de lei ordinária no Brasil, desde 1990, estabelece o melhor interesse da criança, em face dos interesses dos pais. Essa norma, alinhada com a Constituição Federal, foi absorvida pelo Estatuto da Criança e do Adolescente e pelo Código Civil.

Se a lei civil não se refere expressamente à afetividade como situação reveladora da filiação, também não o faz quanto à verdade biológica, considerando a presença da presunção pater is est no ordenamento jurídico. Não obstante, em nome da verdade dos fatos - em seu aspecto biológico - a jurisprudência foi mitigando esses

\footnotetext{
${ }^{180}$ FACHIN, Luiz Edson. Comentários ao Novo Código Civil. Do Direito de Família. Do direito pessoal. Das Relações de Parentesco. Arts. 1.591 a 1.638. Vol. XVIII - Coord. Sávio de Figueiredo Feitosa -1 ${ }^{\mathrm{a}}$ edição. Rio de Janeiro: Forense, 2003, pág. 25.

${ }^{181}$ ALMEIDA, Maria Christina. A Paternidade Sócioafetiva e a Formação da Personalidade. O Estado e os Estados de Filiação. Revista Jurídica Del Rey, Belo Horizonte : Del Rey/IBDFAM, 2002, n. 8, p. 24, maio 2002. (Número especial).
} 
rigores, conforme já exposto. O mesmo vem sendo feito com relação à verdade socioafetiva. Sobre o papel dos operadores do direito ante as lacunas do ordenamento, assevera Francisco José Ferreira Muniz: “nessa medida, a decisão judicial, ao integrar a lacuna para resolver o caso concreto, esboça, para além disso, o desenho da norma jurídica que o legislador deverá editar para, em futuros desenvolvimentos do sistema, preencher o vazio normativo existente" 182

Diante da constatação histórico-social de que a paternidade não se esgota na visão reducionista do mero ato de geração, mas é construída pelos laços afetivos e de solidariedade e pela influencia do ambiente familiar - visto que os laços de afeto derivam da convivência, da proximidade, e não do sangue - os testes científicos não podem, e jamais poderão alcançar a realidade que envolve os laços paterno-filiais.

Nesse sentido, o pai é muito mais importante como executor de uma função do que, propriamente como genitor.

Estas novas idéias consagram a proteção dos interesses dos filhos, a ponto de podermos afirmar que a ascendência genética pode vir a ser sacrificada em respeito ao melhor interesse da criança, o qual preside, hoje, todo o tratamento de filiação no Direito de Família brasileiro.

Sobre o tema, esclarece Paulo Luiz Netto Lôbo, "a verdade socioafetiva em sentido estrito, quando já constituído o estado de filiação e de paternidade, que não pode ser desfeito, porque derivado da convivência familiar duradoura. Três hipóteses de filiação, apenas socioafetivas, podem ser destacadas no nosso Código Civil de 2002. Primeira, adoção. Vejam no art. 1.626 do Código Civil a respeito. Segunda, posse do estado de filiação. Vejam no art. 1.605 a respeito. E a terceira, a concepção por inseminação artificial heteróloga. Vejam no art. 1.597. Essas relações de paternidade e filiação são integral e exclusivamente socioafetivas. E não pode o filho adotado vindicar a paternidade biológica ou a maternidade biológica. E não pode, como já disse, o filho gerado com sêmen do homem que não o marido vindicar a paternidade biológica desse outro homem". 183

O princípio do melhor interesse do menor, inverteu, no nosso ordenamento a prioridade. Antes, ante o conflito entre filiação biológica e socioafetiva, prevalecia, geralmente, a primeira, baseado no interesse dos pais biológicos, o interesse do

${ }^{182}$ MUNIZ, José Ferreira. In. O direito de família na solução dos litígios. Textos de direito civil, Curitiba, Juruá, 1998, p. 116.

${ }^{183}$ LÔBO, PAULO LUIZ NETTO. A família enquanto estrutura de afeto. In. DIAS, Maria Berenice e BASTOS, Eliene Ferreira. Família além dos mitos. Ed. Del Rey, Belo Horizonte, 2008, pág. 257. 
menor, objeto e não sujeito da disputa, não era determinante. Entretanto, com a inversão dos interesses, o julgador, ante o caso concreto, deverá observar o melhor interesse do menor e decidir se a sua realização pessoal estará assegurada entre os pais biológicos ou entre os pais não biológicos. Deve ser ponderada a convivência familiar, constitutiva da posse do estado de filiação, é esta prioridade absoluta da criança e do adolescente (art. 227, da Constituição Federal).

Sobre a observação do princípio do melhor interesse do menor, ante o conflito biológico e afetivo, analisa José Luiz Gavião de Almeida: "surge então um primeiro problema, qual o de se saber quem é, realmente a mãe: aquela que cria ou a que deu à luz. A solução parece difícil ante a perspectiva utilizada na interpretação dos direitos que afetam o caso. É que a jurisprudência de nossos Tribunais, calcada em larga doutrina, vem-se inclinando no sentido de que o direito regula a relação de filiação deve ser aplicado tendo em vista antes os interesses dos filhos. Assim, em litígio onde se dispute a guarda de filho trocado, não é descartável a hipótese de que este fique com a mãe de criação, posto local menos traumático ao menor". ${ }^{184}$

E esta parece ser efetivamente a solução mais adequada. Basta verificar nas demandas de paternidade que, muitas vezes o filho conhece seu pai por meio do DNA, mas não é reconhecido por ele por meio do afeto.

O dado genético é previamente definido. A relação biológica se estabelece de pronto. A posse de estado de filho é um dado cultural, que deve ser construído, com base no afeto. Ideal a identificação destes dois elementos nas mesmas pessoas, contudo, nem sempre isto é possível. A fragmentação destes elementos exige uma resposta atual e de encontro aos anseios da sociedade pelo ordenamento jurídico.

Quando a família assume o perfil do núcleo de afetividade e realização pessoal de todos os seus membros, o valor jurídico do afeto deve nortear o reconhecimento da paternidade predominante.

Com o reconhecimento da paternidade afetiva, atendendo ao princípio do melhor interesse do menor, o filho terá todos os direitos de filho.

Com efeito, a paternidade passou a ser vista como uma relação psicoafetiva, existente na convivência duradoura e presente no ambiente social, capaz de assegurar ao filho não só um nome de família, mas, sobretudo afeto, amor, dedicação e

${ }^{184}$ ALMEIDA, José Luiz Gavião. O Direito de Família e a Constituição de 1998. In Carlos Alberto Bittar (Org.). O Novo Estatuto da Filiação, São Paulo, Saraiva, 2003, pág. 171. 
abrigo assistencial reveladores de uma convivência paterno-filial, que, por si só, é capaz de justificar e identificar a verdadeira paternidade.

Dessa forma, identificar a origem bem como definir o fundamento biológico, jurídico, ou socioafetivo, que deva prevalecer no estabelecimento das relações paterno-materno-filiais, é tarefa que está a exigir do aplicador do direito observância plena dos valores, princípios e normas constitucionais, tendo a dignidade da pessoa humana como valor essencial e fundamento indispensável de qualquer ordenamento jurídico.

Registramos que o estado de filiação, decorrente da estabilidade dos laços afetivos construídos no cotidiano de pai e filho, fundamento essencial da atribuição de paternidade ou maternidade, não guarda qualquer relação com o direito de cada pessoa ao conhecimento de sua origem genética. São duas situações distintas, tendo a primeira natureza de direito de família e a segunda de direito da personalidade.

Sobre o tema, esclarece Luiz Edson Fachin: "No contexto da filiação sustenta-se o direito ao conhecimento da ascendência genética: "todo ser humano tem um pai biológico, de quem herda seus caracteres genéticos. Mas tem pai que não sabe que é pai e filho que não sabe do pai. Tem, ainda, filho que tem pai de coração, porém lhe carece o conhecimento de suas origens biológicas"; em verdade, como bem se reconhece, "a paternidade, mais do que ato de procriação, é fato cultural. A procura pelo vínculo biológico é um meio de melhor alcançar a dignidade humana do filho, uma vez que não existam vínculos socioafetivos suficientes para superar o dado genético em razão do amor." Não há, a rigor, fórmula geral e abstrata capaz de compreender a gama de situações humanas que se vertem em demandas sobre a paternidade e litígios concernentes aos filhos na separação e no divórcio. O Direito administra possibilidades num campo recheado de complexidade." 185

Enfim, para a definição da paternidade o que se coloca em lugar de maior relevância é o atendimento do interesse na constituição de um vínculo parental, observado o melhor interesse da criança, que oportunize a convivência familiar para o desenvolvimento afetivo, ético, psicológico e intelectual do menor.

Normalmente a paternidade se assenta em três pilares: o jurídico (o marido da mãe é por presunção pai do filho tido pela mulher com a qual está casado), o biológico (o marido da mãe é presumivelmente o autor genético da fecundação) e o sócio-

\footnotetext{
${ }^{185}$ FACHIN, Luiz Edson. Comentários ao Novo Código Civil. Do Direito de Família. Do direito pessoal. Das Relações de Parentesco. Arts. 1.591 a 1.638. Vol. XVIII - Coord. Sávio de Figueiredo Feitosa $-1^{\text {a }}$ edição. Rio de Janeiro: Forense, 2003, pág. 73/74.
} 
afetivo (o marido da mãe trata a criança - e por ela é tratado - como pai). A falta de coincidência desses dados pode gerar complexidade.

Assim, na tentativa de localizar respostas para a verdade da filiação, sopesando os elementos jurídico, biológico e afetivo, há que se considerar que o vínculo pai-filho se constrói não sendo apenas um dado. Relevante, pois, a verificação da formação do elo pai-filho, baseado no afeto. Não verificada a afetividade na relação paterno-filial, como até então discorrido, não há como considerar pai aquele que tão somente emprestou sua colaboração na geração genética da pessoa. Da mesma forma, pai também pode não ser aquele a quem o ordenamento jurídico presuntivamente atribui a paternidade.

Esta tendência, seguindo a melhor orientação doutrinária e jurisprudencial foi acolhida, na I Jornada de Direito Civil do Conselho da Justiça Federal nos Enunciados 103 e 130, quando reconhecida a noção de paternidade socioafetiva como forma de parentesco civil.

O Enunciado 103 esclarece que o artigo 1593 do Código Civil de 2002 reconhece outras espécies de parentesco civil além daquele decorrente da adoção, acolhendo assim, a noção de que há parentesco civil no vinculo parental proveniente quer das técnicas de reprodução assistida heteróloga relativamente ao pai (ou mãe) que não contribuiu com seu material fecundante, quer da paternidade socioafetiva, fundada na posse do estado de filho.

O Enunciado 130 faz uma proposição sobre o artigo 1.601 do Código Civil. Sua redação atual: "Cabe ao marido o direito de contestar a paternidade dos filhos nascidos de sua mulher, sendo tal ação imprescritível. Parágrafo único: Contestada a filiação, os herdeiros do impugnante têm direito de prosseguir na ação.” Redação proposta: “Cabe ao marido o direito de contestar a paternidade dos filhos nascidos de sua mulher, sendo tal ação imprescritível. Parágrafo primeiro. Não se desconstituirá a paternidade caso fique caracterizada a posse do estado de filho. Parágrafo segundo. Contestada a filiação, os herdeiros do impugnante têm direito de prosseguir na ação.”

Na III Jornada de Direito Civil, no Enunciado 256, quanto ao artigo 1.593 restou igualmente reconhecido que a posse do estado de filho (parentalidade socioafetiva) constitui modalidade de parentesco civil.

O Estatuto das Famílias, Projeto de Lei no 2.285/2007, no Capítulo I do Título IV, destinado à Filiação, também na linha da melhor doutrina e jurisprudência a 
respeito do tema reconhece expressamente a paternidade socioafetiva como forma de parentesco civil em seus artigos 70 a $77 .{ }^{186}$

Dos dispositivos mencionados, possível extrair a preocupação do legislador não só com o reconhecimento da paternidade socioafetiva, reconhecida em razão da posse do estado de filho, mas principalmente, na possibilidade de constituição da paternidade quando esta não existe e nunca para desconstituir a existente.

Por tal razão, entendemos ser louvável a proposição de possibilitar o reconhecimento do ascendente genético, garantindo o direito fundamental da dignidade da pessoa humana em conhecer o seu ascendente biológico, sem, no entanto, criar laços de parentesco, mantendo a paternidade existente.

Existem algumas questões inquietantes, no tocante à discussão entre paternidade biológica e paternidade afetiva, que têm sido constantemente levadas ao Poder Judiciário, na busca de uma solução a cada caso concreto que, por oportunas, serão adiante tratadas.

A matéria não foi abordada pelo nosso legislador, que deixou a cargo dos julgadores a formação de uma jurisprudência sobre o assunto. Apesar dos nossos Tribunais estarem caminhando no sentido de reconhecimento da paternidade afetiva a matéria ainda não é pacífica e gera inúmeras controvérsias, posto tratar de questão tão delicada e com tantas peculiaridades a cada caso.

Imaginemos algumas situações: 1. O filho é registrado pelo pai afetivo adoção à brasileira - segundo o nosso ordenamento presume-se pai, o pai registral. Entretanto, em um determinado momento o filho descobre que seu pai biológico não é o seu pai registral e decide investigar a sua origem genética, ou, até mesmo a mãe se separa do pai registral e, na qualidade de representante do filho menor decide investigar a paternidade do filho. Neste momento, temos um ponto polêmico, que contrapõe dois valores: a) de um lado: o direito do filho de saber a sua origem genética, que possui como

\footnotetext{
${ }^{186}$ Estatuto das Famílias. Projeto de Lei no . 2.285/2007. Artigo 71: “A filiação prova-se pelo registro de nascimento. $\S 2^{\circ}$. Também se prova a filiação por qualquer modo admissível em direito, quando houver posse de estado de filho." Artigo 74: "O filho registrado ou reconhecido pode impugnar a paternidade, desde que não caracterizada a posse do estado de filho em relação aquele que o registrou ou o reconheceu." Artigo 75: "O filho não registrado ou não reconhecido pode, a qualquer tempo, investigar a paternidade ou maternidade, biológica ou socioafetiva" Artigo 76: "Cabe ao marido, ao convivente ou à mulher o direito de impugnar a paternidade ou a maternidade que lhe for atribuída no registro civil. §2. Não cabe a impugnação da paternidade ou maternidade: II. caso fique caracterizada a posse do estado de filho. Artigo 77. É admissível a qualquer pessoa, cuja filiação seja proveniente de adoção, filiação sócio-afetiva, posse do estado ou de inseminação artificial heteróloga, o conhecimento de seu vínculo genético sem gerar relação de parentesco. Parágrafo único. $\mathrm{O}$ ascendente genético pode responder por subsídios necessários à manutenção do descendente, salvo em caso de inseminação artificial heteróloga.
} 
fundamento o princípio da dignidade da pessoa humana e os direitos da personalidade, posto ser o estado de filiação um direito personalíssimo, portanto indisponível e; b) de outro lado: temos que a investigação de paternidade serve para dar pai a quem não tem, portanto só é possível para constituir paternidade, nunca para desconstituí-la.

O professor Paulo Luiz Netto Lobo ${ }^{187}$, em artigo publicado nos Anais do IV Congresso do Instituto Brasileiro de Direito de Família, "Direito ao estado de filiação e direito à origem genética: uma distinção necessária", sobre o tema, é pontual ao dissociar as questões relativas ao direito da personalidade das questões de direito de família, concluindo que a verdadeira paternidade é fruto do afeto e é perfeitamente compatível com a descoberta da ascendência genética:

"O estado de filiação, que decorre da estabilidade dos laços afetivos construído no cotidiano de pai e filho, constitui essencialmente da atribuição da paternidade/maternidade. Nada tem a ver com o direito de cada pessoa ao conhecimento de sua origem genética. São duas situações distintas, tendo a primeira natureza do Direito de Família e a segunda de direitos da personalidade. As normas e os efeitos não se confundem. O objeto da tutela do direito ao conhecimento da origem genética é assegurar o direito da personalidade, na espécie direito à vida, pois os dados da ciência atual apontam para a necessidade de cada indivíduo saber a história de saúde de seus parentes biológicos próximos para prevenção da própria vida. Não há necessidade de se atribuir paternidade a alguém para se ter o direito da personalidade de, por exemplo, conhecer seus ascendentes biológicos. Em contrapartida, a paternidade deriva do estado de filiação, independentemente da origem. É inadmissível que sirva de base para vindicar novo estado de filiação, contrariando o já existente."

Interessante trazer alguns julgados recentes dos nossos Tribunais que, diante do conflito da paternidade afetiva e biológica, têm reconhecido a preponderância da paternidade afetiva, ainda que não neguem o direito de conhecimento à ascendência genética. $^{188}$ 187 LOBO, Paulo Luiz Netto. Direito ao estado de filiação e direito à origem genética: uma distinção
necessária. Anais do IV Congresso do Instituto Brasileiro de Direito de Família, Ed. Del Rey, belo Horizonte,
2004. p. 505-530.
188 "DECLARATÓRIA DE PATERNIDADE BIOLÓGICA COMBINADA COM RETIFICAÇÃO DE
REGISTRO CIVIL DA FILHA - PATERNIDADE BIOLÓGICA RECONHECIDA POR EXAME DE DNA
- SENTENÇA DE PROCEDENCIA - ESPECIFICIDADE DA SITUAÇÃO CONCRETA EM QUE A
FILHA ESTÁ INTEGRADA NA FAMÍLIA FORMADA PELA MÃE BIOLÓGICA E O PAI SÓCIO-
AFETIVO - INCONVENIÊNCIA PARA A CRIANÇA, EM PROL DE QUEM EXISTEM NORMAS DE
PROTEÇÃO DE SEU DESENVOLVIMENTO SÓCIO-AFETIVO, DE SE ALTERAR A SITUAÇÃO JAA
EXISTENTE E CONSOLIDADE - RESTRIÇÃO DA SENTENÇA AOS EFEITOS MERAMENTE
DECLARATÓRIOS DA VERDADE FILIAL - MANTENÇA DO REGISTRO ATACADO COM 
Registramos que, em todas as decisões mencionadas, pudemos observar, nos casos de desconstituição de relação de paternidade, que o registro não se tratou de erro, mas de registro consciente de paternidade/maternidade, que, depois de consolidada a

OBSERVANCIA DO PROCEDIMENTO DETERMINADO PELO ECA (art. 47, § $2^{\circ}$ ), COM RELAÇÃO À ADOÇÃO - APELO PARA TAIS FINS PROVIDO EM PARTE" (Apelação Civel no 369.958-4/8-00, 9 Câmara de Direito Privado do Tribunal de Justiça de São Paulo, rel. Des. João Carlos Garcia, j. 31/01/2006). "INVESTIGAÇÃO DE PATERNIDADE - Contraposição entre paternidade biológica e paternidade sócioafetiva - Necessidade de invocação dos ditames constitucionais, dentre eles, o princípio da dignidade da pessoa humana e a proteção da família, para adequada solução da questão - paternidade do requerente que restou confirmada em grau praticamente absoluto de probabilidade - Criança reconhecida como se filho fosse, desde seu nascimento, pelo cônjuge de sua genitora - Verdade da paternidade que não pode prevalecer sobre os superiores interesses da criança, perfeitamente integrada no seio da família - Convivência harmoniosa com seus integrantes verificada - Acolhimento da pretensão do requerido que teria o condão de trazer traumas insuperáveis à criança, em plena fase de formação - Persistência do afeto entre os requeridos que construíram relação de mútuo auxílio e respeito - Vínculo meramente sanguíneo desconsiderado Paternidade sócio-afetiva reconhecida - Inversão da disciplina da sucumbência - Recurso provido. (Apelação Cível no 489.102-4/8, $1^{\text {a }}$ Câmara de Direito Privado do Tribunal de Justiça de São Paulo, rel. Des. Luiz Antonio de Godoy, j. 11/03/2008).

“APELAÇÃO CIVEL. INVESTIGATÓRIA DE PATERNIDADE. RECONHECIMENTO DA FILIAÇÃO BIOLÓGICA. PAI REGISTRAL. INTELIGÊNCIA DO ART. 1.614 DO CÓDIGO CIVIL. O apelante pretende ver desconstituído um estado de filiação sobejamente consolidado ao longo de mais de 45 anos. Não se trata de restabelecer a VERDADE registral fazendo adequar-se o registro aos dados cromossômicos, pois não menos verdadeira é a correspondência que há com a VERDADE SOCIOLÓGICA, consolidada na posse de estado de filho. NEGARAM PROVIMENTO. UNÂNIME" (Apelação Cível No 70018465112, Sétima Câmara Cível, Tribunal de Justiça do RS, Relator: Luiz Felipe Brasil Santos, Julgado em 11/04/2007)

"INVESTIGAÇÃO DE PATERNIDADE. IMPRESCRITIBILIDADE. FILIAÇÃO SOCIOAFETIVA E BIOLÓGICA. EFEITOS. Validade da sentença. Não há falar de nulidade da sentença por ter ocorrido sucinta fundamentação da decisão, a qual afastou as preliminares argüidas quando decidiu pela procedência da ação. Desnecessário ter havido processo prévio para anulação do registro de nascimento da recorrida. Prescrição.Proibindo a norma constitucional $\left(\right.$ art.227, $\left.\$ 6^{\circ}\right)$ qualquer designação discriminatória relativa à filiação, não se pode conceber da existência de prazo prescricional para averiguação da verdade biológica ao filho que possua pai registral, constituindo direito fundamental a dignidade da sua pessoa. Mérito. Da filiação socioafetiva. Reconhecida a filiação socioafetiva, a investigação de paternidade procedente não desconstitui o registro paternal, pois a prevalência da socioafetividade faz com que o conhecimento da paternidade biológica não gere seqüela patrimonial. Afastada a mercantilização do afeto. Verba sucumbencial redimensionada. APELO PARCIALMENTE PROVIDO. POR MAIORIA". (Apelação Cível $\mathrm{n}^{\circ}$ 70004510483, Oitava Câmara Cível, Tribunal de Justiça do RS, Relator: Rui Portanova, Julgado em $31 / 10 / 2002)$.

"Investigação de paternidade - Prova hematológica - Paternidade biológica reconhecida por exame de DNA Criança, todavia, registrada anteriormente pelo companheiro de sua mãe - Paternidade sócio-afetiva ou adoção à brasileira configurada - Prevalecimento desta última pois a filha esta perfeitamente integrada na família formada pela genitora biológica e o pai sócio-afetivo - Inconveniência para a criança, em prol de quem existem normas de proteção de seu desenvolvimento sócio-afetivo, de se alterar a situação já existente e consolidada - Restrição da sentença aos efeitos meramente declaratórios, sem alterar o registro de nascimento da filha, com a observância do procedimento determinado pelo art. 47, § $2^{\circ}$ do Estatuto da Criança e do Adolescente - Recurso provido em parte para esse fim.” (Apelação cível n 369958-4/8-00 Novo Horizonte $-9^{\text {a }}$ Câmara de Direito Privado - j. 31/01/06 - Rel. Des. João Carlos Garcia - v.u., TJMG). "APELAÇÃO CÍVEL. DESCONSTITUIÇÃO DE REGISTRO CIVIL. ADOÇÃO À BRASILEIRA. PREPONDERANCIA DA FILIAÇÃO SOCIOAFETIVA SOBRE A BIOLOGICA. MELHOR INTERESSE DA CRIANÇA. 1 - O reconhecimento voluntário de paternidade, daquele que, sabidamente, não é filho da pessoa, sem seguir o procedimento legal, é chamado de "adoção à brasileira". 2 - A "adoção à brasileira", apesar de contrária a lei, vem sendo aceita pela sociedade em razão da preponderância da filiação sócioafetiva sobre a biológica e do princípio do melhor interesse da criança. 3 - Deverá ser mantido o registro civil da criança, mesmo que contrariando a verdade biológica, quando lhe for o mais conveniente. 4 - Recurso improvido." (Apelação cível n 1.0672.00.029573-9/001 - Comarca de Sete Lagoas - Relator: Des. Nilson Reis, j. 27/02/2007, TJMG). 
relação, qualquer que seja o interesse, ou até mesmo em caso de arrependimento, não há como ser desfeito, em prol do interesse do menor e da verdade socioafetiva estabelecida.

Invocados os princípios constitucionais da proteção da entidade familiar pelo Estado e da dignidade da pessoa humana, fundamentam os julgadores, a prevalência da relação socioafetiva, quando estabelecida e consolidada a relação paterno-filial, em prol do menor e dos laços e identidades formados, que, não poderão ser desfeitos sem traumas para as crianças.

Mas a questão ainda não é tranquila, em recente decisão, a Terceira Turma do Superior Tribunal de Justiça decidiu que o reconhecimento do estado de filiação constitui direito personalíssimo, indisponível e imprescritível, que pode ser exercitado sem qualquer restrição, em face dos pais ou dos herdeiros, na busca da filiação biológica, que prevaleceu no caso. ${ }^{189}$

É extremamente importante, que a cada caso concreto o legislador pondere a situação e verifique pelo melhor atendimento dos interesses do filho. Não obstante a possibilidade da identificação genética do genitor, necessário verificar, para a decisão, se houve o estabelecimento da paternidade afetiva, com base na posse de estado de filho.

Na última decisão mencionada, a Ministra Relatora parece ter optado pela prevalência da paternidade biológica, dado a peculiaridade do caso.

189 "Direito civil. Família. Recurso especial. Ação de investigação de paternidade e maternidade. Vínculo biológico. Vínculo sócio-afetivo. Peculiaridades. - A "adoção à brasileira", inserida no contexto de filiação sócio-afetiva, caracteriza-se pelo reconhecimento voluntário da maternidade/paternidade, na qual, fugindo das exigências legais pertinentes ao procedimento de adoção, o casal (ou apenas um dos cônjuges/companheiros) simplesmente registra a criança como sua filha, sem as cautelas judiciais impostas pelo Estado, necessárias à proteção especial que deve recair sobre os interesses do menor. - O reconhecimento do estado de filiação constitui direito personalíssimo, indisponível e imprescritível, que pode ser exercitado sem qualquer restrição, em face dos pais ou seus herdeiros. - O princípio fundamental da dignidade da pessoa humana, estabelecido no art. $1^{\circ}$, inc. III, da CF/88, como um dos fundamentos da República Federativa do Brasil, traz em seu bojo o direito à identidade biológica e pessoal. - Caracteriza violação ao princípio da dignidade da pessoa humana cercear o direito de conhecimento da origem genética, respeitando-se, por conseguinte, a necessidade psicológica de se conhecer a verdade biológica. - A investigante não pode ser penalizada pela conduta irrefletida dos pais biológicos, tampouco pela omissão dos pais registrais, apenas sanada, na hipótese, quando aquela já contava com 50 anos de idade. Não se pode, portanto, corroborar a ilicitude perpetrada, tanto pelos pais que registraram a investigante, como pelos pais que a conceberam e não quiseram ou não puderam dar-lhe o alento e o amparo decorrentes dos laços de sangue conjugados aos de afeto. - Dessa forma, conquanto tenha a investigante sido acolhida em lar "adotivo" e usufruído de uma relação sócio-afetiva, nada lhe retira o direito, em havendo sua insurgência ao tomar conhecimento de sua real história, de ter acesso à sua verdade biológica que lhe foi usurpada, desde o nascimento até a idade madura. Presente o dissenso, portanto, prevalecerá o direito ao reconhecimento do vínculo biológico. - Nas questões em que presente a dissociação entre os vínculos familiares biológico e sócio-afetivo, nas quais seja o Poder Judiciário chamado a se posicionar, deve o julgador, ao decidir, atentar de forma acurada para as peculiaridades do processo, cujos desdobramentos devem pautar as decisões Recurso especial provido."(Recurso Especial n 833712/RS, Relatora Min. Nancy Andrighi, Terceira Turma,STJ, j. 17/05/2007). 
É primordial que os julgadores exerçam o seu poder discricionário de modo cauteloso neste momento tão delicado, evitando assim a mercantilização do afeto, onde diversas famílias constituídas com base na solidariedade e no afeto poderão ser desfeitas para a busca de uma ascendência genética com intenções de cunho estritamente pecuniário.

Em um segundo momento, poderíamos imaginar uma outra situação, na qual, o pai que registrou o filho como se fosse seu, pretende, posteriormente negar a paternidade. Para a solução desta situação, antes de tudo, cumpre lembrar que a declaração de paternidade livre e espontânea é ato irrevogável e a sua anulação só é possível nos casos previstos em lei: dolo, erro e coação.

Ademais, não há como desconstituir o vínculo parental se há presença de posse de estado de filho, eis que se forma um vínculo afetivo com a criança que transcende o interesse do pai, que passa a ter responsabilidade com a criança que assumiu - este ato que se equipara à adoção e não é passível de arrependimento. E felizmente, é neste sentido que tem decidido os nossos Tribunais. ${ }^{190}$.

Entretanto, existe a possibilidade de não ter sido configurada a paternidade afetiva entre o pai registral e o filho. Nesses casos, será possível a anulação do registro? Acredito, como mencionado ao longo do presente trabalho, que o julgador deverá se orientar pelo princípio do melhor interesse do filho, decidindo a cada caso. Nestes casos, por não ter sido configurada a posse de estado de filho, admite-se a anulação do registro, de acordo com decisão proferida pelo Tribunal de Justiça do Rio Grande do Sul. ${ }^{191}$.

190 “ALIMENTOS. FILIAÇÃO SOCIOAFETIVA. Julgada improcedente ação negatória de paternidade em face do reconhecimento do vínculo socioafetivo que se criou e consolidou ao longo de 16 anos, inquestionável a obrigação alimentar do genitor. Presumidas as necessidades do alimentando, que apresenta seqüelas físicas e neurológicas irreversíveis decorrentes de acidente de trânsito sofrido na infância, devem elas balizar o pensionamento quando o alimentante não demonstra, como the incumbia, as suas reais possibilidades financeiras. Apelo desprovido, por maioria" (Apelação Cível No 70006047971, Sétima Câmara Cível, Tribunal de Justiça do RS, Relator: Maria Berenice Dias, Julgado em 04/06/2003).

"Quem sabendo não ser o pai biológico, registra como seu filho de companheira durante a vigência de união estável estabelece uma filiação socioafetiva que produz os mesmos efeitos que a adoção, ato irrevogável. O pai registral não pode interpor ação negatória de paternidade e não tem legitimidade para buscar a anulação do registro de nascimento, pois inexiste vício material ou formal a ensejar a desconstituição." (Embargos Infringentes no 5999.2777.365 - 4 Câmara Cível - Tribunal de Justiça do Rio Grande do Sul — Rel. Des. Maria Berenice Dias - DJRS 21/10/1999)

191 "AÇÃO ANULATÓRIA DE RECONHECIMENTO. PARENTALIDADE SOCIOAFETIVA NÃO CONFIGURADA. A paternidade não é apenas um mero fato, um dado biológico, e sim, uma relação construída na vida pelos vínculos que se formam entre o filho e seu genitor. Caso em que as evidências levam à conclusão de que o reconhecimento da paternidade foi decorrente de erro, e não de decisão consciente do autor, o que o levou a afastar-se da criança, tão-logo soube que não era seu filho, entre ambos não se formando a relação socioafetiva que deve ser preservada. Negaram provimento, por maioria, vencido o Relator" (Apelação Cível No 70000849349, Sétima Câmara Cível, Tribunal de Justiça do RS, Relator: José Carlos Teixeira Giorgis, Julgado em 20/08/2003). 
Ser pai, como visto, depende muito mais da assunção da função de pai que fornecer o material genético. Configurada a posse de estado de filho, estabelecido o vínculo pelo afeto, este, construído com a convivência, de rigor o reconhecimento, pelo nosso ordenamento, da paternidade afetiva, como modo de estabelecimento da paternidade.

Oportuna a abordagem de tais questões polêmicas relativas à paternidade afetiva, uma vez que, demonstra a complexidade e a importância do instituto no estabelecimento das relações paterno-filiais.

Sendo o afeto fonte constitutiva do estado de filiação, o estabelecimento de tal vínculo, nas famílias reconstituídas entre o filho e o novo cônjuge ou companheiro da mãe, por certo, é capaz de legitimar direitos e deveres recíprocos entre os membros da família, tal como, o exercício da autoridade parental, de forma complementar aos pais biológicos. 


\section{VI - PODER FAMILIAR OU AUTORIDADE PARENTAL?}

O estudo da autoridade parental, especialmente de seu conceito e características na família contemporânea, é extremamente importante, pois, como se demonstrará, a relação de autoridade entre pais e filhos não se restringe aos laços de sangue, podendo ser muito mais abrangente, na medida em que se direciona notadamente à formação do menor, tendo em vista o seu melhor interesse, o que, sobretudo, torna legítimas as relações nas famílias reconstituídas.

Os filhos, enquanto menores estão sujeitos ao poder familiar, é o que estabelece o artigo 1.630 do Código Civil de 2002.

Destarte, como se verifica no dispositivo legal, hoje, basta a condição de filho e a menoridade para a existência da relação de autoridade parental.

Para o professor Roberto João Elias, "todo filho, desde que reconhecida a paternidade, de forma voluntária, ou não, é submetido ao pátrio poder e, como consequiência, torna-se sujeito de vários direitos, que podem ser exigidos dos pais." ${ }^{192}$

De fato, atualmente todo filho é sujeito do poder familiar, independente do estado civil dos genitores - que devem exercer a sua função qualquer que seja o seu estado civil -, necessária apenas a condição de filho. Daí se extrai que o exercício da autoridade parental se dá em prol dos filhos, visando ao seu melhor interesse.

\section{DO PÁTRIO PODER AO PODER FAMILIAR}

Isto porque, outrora, sob a égide do Código Civil de 1916, antes do advento da Constituição Federal de 1988, quando ainda existia discriminação quanto aos filhos em razão de sua origem a autoridade parental era dirigida apenas aos filhos legítimos, legitimados e os legalmente reconhecidos, deixando à margem os filhos ilegítimos, conforme redação original do artigo 379: "Os filhos legítimos, os legitimados, os legalmente reconhecidos e os adotivos estão sujeitos ao pátrio poder, enquanto menores."

Neste sentido, registra Luiz Edson Fachin a importância da dissociação do estado da filiação do estado civil dos pais: "Esse princípio trouxe uma contribuição relevantíssima para se entender o estatuto jurídico da filiação, dissociado, separado do

${ }^{192}$ ELIAS, Roberto João. Pátrio Poder: guarda dos filhos e direito de visita. Ed. Saraiva, 1999, pág. 02. Observação: expressão pátrio poder utilizada pelo autor, obra escrita sob a égide do Código Civil de 1916. 
estado civil dos pais, sendo reconhecida aos filhos a condição impostergável de serem também sujeitos da relação de autoridade parental ou poder familiar, conforme o novo Código Civil, eis que, como já se disse, nesse processo, o adulto também é destinatário do exercício desta autoridade, porque aquele que verdadeiramente educa se auto-reeduca no processo educativo. E o filho ou a criança é sujeito desse processo." 193

O poder familiar é a denominação que adotou o Código Civil de 2002 para o pátrio poder, tratado no Código de 1916. O instituto, acompanhando a evolução das relações familiares, mudou significativamente ao longo do tempo, distanciando-se de sua função originária, voltada ao exercício de poder dos pais sobre os filhos, para constituir um múnus, em que ressaltam os deveres.

A expressão pátrio poder - resquício de uma sociedade patriarcal em certa época dominante - está presente na maior das legislações alienígenas, constituindo uma terminologia clássica, adotada para definir a submissão dos filhos menores à autoridade dos pais. Sem embargo, modestamente, insistimos em nossa crítica, lembrando que, na verdade, os pais têm em relação aos filhos menores, muito mais deveres do que poderes, dentre os primeiros se alinhando a obrigação de proporcionarem os pais aos filhos, assistência, sustento e educação, deveres esses que, aliás, quando descumpridos, dão motivo a sanções legais seriíssimas, que vão da suspensão à extinção do denominado pátrio poder. $^{194}$

Roberto João Elias lembra que "o conceito de pátrio poder, em nosso tempo, é bem diverso do existente na Antiguidade, antes do advento do Cristianismo. Outrora, como ocorria, por exemplo, entre os romanos, o instituto representava para os seus titulares um poder absoluto, inclusive de vida e morte sobre os filhos." 195

O pátrio poder, reflexo da família patriarcal, matrimonializada e hierarquizada representava o poder que o pai tinha sobre os filhos. Sob a vigência do Código Civil de 1916, era o marido, como chefe da sociedade conjugal, titular do pátrio poder sobre os filhos menores, e somente na sua falta ou impedimento tal incumbência passava a ser atribuída à mulher.

\footnotetext{
${ }^{193}$ Fachin. Luiz Edson. Princípios constitucionais do direito de família brasileiro contemporâneo. In. DIAS, Maria Berenice e BASTOS, Eliene Ferreira. Família além dos mitos. Ed. Del Rey, Belo Horizonte, 2008, pág. 128.

194 PEREIRA, Áurea Pimentel Pereira. Da proteção da pessoa dos filhos na dissolução da sociedade conjugal: tratamento dado pela legislação brasileira, revista Doutrinária, Rio de Janeiro, a.4, no 4, p. 50, 2001. 195 ELIAS, Roberto João. Pátrio Poder: guarda dos filhos e direito de visita. Ed. Saraiva, 1999, pág. 05. Observação: expressão pátrio poder utilizada pelo autor, obra escrita sob a égide do Código Civil de 1916.
} 
Apenas com o advento do Estatuto da Mulher Casada, Lei no 4.121/62, emancipada a mulher casada, nova redação foi dada ao artigo 380 do Código Civil de 1916: "Durante o casamento, compete o pátrio poder aos pais, exercendo-o o marido em colaboração com a mulher. Na falta ou impedimento de um dos progenitores passará o outro a exercê-lo com exclusividade. Parágrafo único. Divergindo os progenitores quanto ao exercício do pátrio poder, prevalecerá a decisão do pai, ressalvando à mãe o direito de recorrer ao juiz para solução da divergência".

Da leitura do dispositivo legal, contudo, observa-se a preponderância do homem sobre a mulher, como evidente resquício de uma sociedade patriarcal. O homem continuava como titular do pátrio poder, concedendo o ordenamento a possibilidade da mulher exercê-lo, em colaboração ao seu marido, todavia, em caso de divergência, automaticamente prevaleceria a decisão do homem.

Fato que somente se modificou com o advento da Constituição Federal de 1988, que, reconhecendo a igualdade entre os cônjuges, concedeu a direção da sociedade conjugal e o poder familiar ao casal.

Outorgado o poder familiar ao casal, havendo divergência entre os cônjuges, não mais prevalece a vontade paterna, e aquele que estiver inconformado deverá recorrer à Justiça, pois o exercício do poder familiar é de ambos os cônjuges, de forma igualitária.

Como até então visto, a família se transformou, a passagem de uma estrutura hierarquizada, baseada no poder, para um centro de convivência, baseado no afeto, por certo, refletiram diretamente nas relações paterno-filiais, fazendo com que, gradativamente, houvesse uma alteração de foco do instituto do pátrio poder.

Para Paulo Luiz Netto Lôbo: “As vicissitudes por que passou a família, no mundo ocidental, repercutiram no conteúdo do poder familiar. Quanto maiores foram a desigualdade, a hierarquização e a supressão de direitos, entre os membros da família, tanto maior foi o pátrio poder e o poder marital. À medida que se deu a emancipação da mulher casada, deixando de ser 'alieni juris', à medida que os filhos foram emergindo em dignidade e obtendo tratamento legal isonômico, independentemente de sua origem, houve redução do quantum despótico, restringindo esses poderes domésticos. No Brasil foram necessários 462 anos, desde o início da colonização portuguesa, para a mulher casada deixar de ser considerada relativamente incapaz (Estatuto da Mulher Casada, Lei n. 4.121, de 27 de agosto de 1962); foram necessários mais 26 anos para consumar a igualdade de direitos e deveres na família (Constituição de 1988), pondo fim, em definitivo, ao antigo 
pátrio poder e ao poder marital. A evolução gradativa deu-se no sentido da transformação de um poder sobre os outros em autoridade natural com relação aos filhos, como pessoas dotadas de dignidade, no melhor interesse deles e da convivência familiar. Essa é sua atual natureza". 196

A alteração do instituto acompanhou a alteração da estrutura familiar. Mudada a base da família para o afeto e tendo como objetivo a entreajuda dos integrantes do grupo familiar, especialmente, a formação adequada dos filhos, do exercício autoritário do poder passou-se à função de educação e proteção dos filhos.

Neste sentido também é a lição do professor Roberto João Elias, "gradativamente, contudo, tal poder teve suas características modificadas, de forma que resta, agora, um direito que é o de exercer determinadas funções, tendo como objetivo a proteção dos filhos. Afirmam, destarte, vários doutrinadores que se trata, na verdade, mais de um conjunto de deveres do que de direitos."197

Observa Juliane Fernandes Queiroz que: “se a própria instituição família se transmudou para a sociológica, onde passaram a preponderar os interesses individuais de seus membros, buscando-se a íntegra formação do indivíduo, a relação paternal não poderia deixar de sofrer sua transformação. A autoridade paterna, tal como concebida no Direito romano e estendida do Brasil colonial até há pouco tempo, não persiste mais nas relações entre pais e filhos". ${ }^{198}$

Neste contexto, a denominação do instituto de 'pátrio poder', alusivo ao poder do pai, foi substituída pelo texto constitucional, por 'poder familiar', voltando-se, dentro do âmbito constitucional da igualdade entre homem e mulher ao poder da família.

\section{PODER OU AUTORIDADE?}

Seguindo as diretrizes constitucionais, o legislador do Código Civil de 2002, adotou a expressão 'poder familiar' em alusão ao princípio da igualdade, deslocando o exercício do poder da figura do pai, para do homem e da mulher: da família.

Contudo, para Paulo Luiz Netto Lôbo, “a denominação ainda não é a mais adequada, porque mantém a ênfase no poder. Todavia, é melhor que a resistente

${ }^{196}$ LÔBO, Paulo Luiz Netto. Do Poder Familiar. In. Direito de Família e o novo Código Civil. Ed. Del Rey, Belo Horizonte, 2001, pág. 143.

${ }^{197}$ ELIAS, Roberto João. Pátrio Poder: guarda dos filhos e direito de visita. Ed. Saraiva, 1999, pág. 05.

${ }^{198}$ QUEIROZ, Juliane Fernandes. Paternidade: aspectos jurídicos e técnicas de inseminação artificial, Belo Horizonte. Del Rey, 2001, p. 49. 
expressão "pátrio poder", mantida inexplicavelmente, pelo Estatuto da Criança e do Adolescente (Lei n. 8.069/90). Com a implosão social e jurídica, da família patriarcal, cujos últimos estertores deram-se antes do advento da Constituição de 1988, não faz sentido que seja reconstruído o instituto apenas deslocando o poder do pai (pátrio) para o poder compartilhado dos pais (familiar), pois a mudança foi muito mais intensa, na medida em que o interesse dos pais está condicionado ao interesse do filho, ou melhor, no interesse de sua realização como pessoa em formação." 199

Com razão o autor. Refletindo as relações familiares da sociedade contemporâneas, o termo mais adequado para o instituto, como tem sido utilizado por boa parte da doutrina, é o de 'autoridade parental', capaz de exprimir o exercício da função dos pais em relação aos filhos, mais como dever do que de direitos, traduzido em uma relação complexa decorrente do parentesco.

O conceito de autoridade, de fato, traduz melhor o exercício de função ou múnus, fundado no interesse dos filhos e a expressão 'parental' melhor identifica a relação de parentesco entre pais e filhos. Delimita o grupo familiar, no qual deve ser exercida a autoridade.

Nesta direção a lição de Luiz Edson Fachin, “a nova legislação veio a atribuir o nome de poder familiar para esse instituto jurídico, precisamente tentando superar a idéia de que tal obrigação recaía apenas sobre o genitor, estipulando que ambos os pais preencham a moldura legal, já que orientação constitucional prevê a igualdade entre marido e mulher. A idéia, enfim, seria de autoridade parental. (...) A nova expressão, contudo, está eivada de imprecisão, já que o instituto não incide sobre a família, senão apenas sobre os pais, de modo que sua definição pode ser formulada a partir dessa premissa, estipulando-se que se trata de um conjunto de direitos e deveres, relativos à pessoa ou aos bens do menor não emancipado, que incide sobre os pais, que o exercem em igualdade de condições tendo em vista o interesse e a proteção de seu filho"200

Registramos que as legislações estrangeiras mais recentes têm optado pela expressão 'autoridade parental', entre as quais, a francesa desde 1970. Nesta linha, João Batista Villela, afirma que a vetusta ordem familiar, hoje, dá lugar ao surgimento de um novo interlocutor no seu ambiente, que é o menor, e, referindo-se à mudança de

${ }^{199}$ LÔBO, Paulo Luiz Netto. Do Poder Familiar. In. Direito de Família e o novo Código Civil. Ed. Del Rey, Belo Horizonte, 2001, pág. 141.

${ }^{200}$ FACHIN, Luiz Edson. Comentários ao Novo Código Civil. Do Direito de Família. Do direito pessoal. Das Relações de Parentesco. Arts. 1.591 a 1.638. Vol. XVIII - Coord. Sávio de Figueiredo Feitosa -1 ${ }^{\mathrm{a}}$ edição. Rio de Janeiro: Forense, 2003, pág. 240. 
designação do instituto na legislação francesa, observa que se abandona o termo poder em favor de autoridade, que é um conceito dominado pela ideia de função. ${ }^{201}$

Pois bem, o poder familiar, atualmente, é uma relação complexa de direitos e deveres entre pais e filhos, exercido pelos pais, no interesse dos filhos, pode ser conceituado como um múnus ou função dos pais.

Arnoldo Wald traduz o poder familiar como "o direito do pai sobre os filhos, outrora considerado como verdadeiro direito subjetivo, é definido, pelo direito contemporâneo, como um poder jurídico, ou seja, como pátrio poder-dever, exercido pelo pai e pela mãe, por delegação do Estado, no interesse da família." 202

Roberto João Elias, por sua vez, afirma que "pode-se, portanto, definir o pátrio poder como um conjunto de direitos e deveres, em relação à pessoa e aos bens dos filhos menores e não emancipados, com a finalidade de propiciar o desenvolvimento integral de sua personalidade. ${ }^{203}$

A autoridade parental é fundamentada no direito subjetivo, inerente à condição de pais, que exercem deveres jurídicos em prol dos filhos. É pois, o conjunto de obrigações dos pais, para com os filhos menores, que abrange, entre outros os deveres de educação, guarda e sustento, material e moral.

Assevera Ana Carolina Brochado Teixeira "o entendimento que prepondera é de que o poder familiar seria um conjunto de direitos e deveres referentes à pessoa e ao patrimônio do menor não emancipado, a que os pais estão atrelados, sendo composto por um rol de deveres para com os filhos, principalmente os de cunho material, intelectual, além da gerência dos bens que possam ter. Assim, sobreporia o compêndio de deveres aos poderes". 204

Pois bem, como até então visto, o poder familiar está menos para poder e mais para dever dos pais. Deve ser encarado como um múnus, legalmente atribuído aos pais. O poder familiar é ônus atribuído aos pais, pelo Estado, em virtude da parentalidade, no interesse dos filhos. É como diz Pietro Pierlingieri, "um verdadeiro ofício, uma situação

\footnotetext{
${ }^{201}$ VILLELA, João Batista. Liberdade e família. Belo Horizonte, FDUFMG, 1980, pág. 29.

${ }^{202}$ WALD, Arnoldo. O Novo Direito de Família. 13.ed. rev. atual. e ampl. pelo autor, de acordo com a Jurisprudência e com Referências ao Projeto de Código Civil, com a Colaboração do Des. Luiz Murillo Fábregas e da Prof ${ }^{a}$ Priscila M. P. Corrêa da Fonseca. São Paulo Saraiva, 2002, pág. 227.

${ }^{203}$ ELIAS, Roberto João. Pátrio Poder: guarda dos filhos e direito de visita. Ed. Saraiva, 1999, pág. 06. Observação: expressão pátrio poder utilizada pelo autor, obra escrita sob a égide do Código Civil de 1916.

${ }^{204}$ TEIXEIRA, Ana Carolina Brochado. Família, guarda e autoridade parental. Ed. Renovar. Rio de Janeiro, 2005, pág. 95.
} 
de direito-dever; como fundamento da atribuição dos poderes existe o dever de exercê-los" 205

O poder familiar, concebido como múnus, é um complexo de direitos e deveres. Não se trata mais de competência delegada pelo Estado para exercício do poder pelos pais sobre os filhos, eis que a cada dever dos pais corresponde um direito do filho e, a cada direito dos pais, corresponde um dever do filho.

Pois bem, na relação paterno-filial a criança e o adolescente não mais são objetos, mas sujeitos, e como tal deverão ser tratados. Assim, enquanto menores não emancipados, os filhos não devem estar subjugados pelos pais - precisam ser assistidos, criados e educados, sendo garantido o respeito mútuo entre pais e filhos. Dessa forma, os pais têm o dever de exercer o poder familiar em relação à prole, cuidando e protegendo-a, visando ao seu pleno desenvolvimento.

Quanto ao tema, Cláudia Lima Marques, registra que "a comunicação está presente no direito de família através das novas maneiras de fazer valer os direitos assegurados aos membros mais fracos do grupo - as crianças - que passam a ser não só consultadas, como também a poder diretamente seus direitos e a ter voz ativa nas decisões (pelo menos algumas) internas da família, resultado de uma nova visão da criança não mais como "objeto" do pátrio poder, mas como sujeito de direitos próprios." 206

Todavia alerta Ana Carolina Brochado Teixeira que o insituto do poder familiar traz uma relação complexa de direitos e deveres entre pais e filhos, e assim, deve ser encarado, uma vez que "o direito subjetivo confere ao indivíduo um poder de ação, com vistas à realização de uma pretensão. Este conceito abarca a idéia de um dever jurídico a ser cumprido por outra pessoa, no sentido de dar, fazer ou deixar de fazer alguma conduta, abrange, por conseguinte, o binômio exigibilidade e satisfação. Daí que a doutrina tradicional reduziu esta situação em dois polos: sujeito ativo - o titular do poder - e sujeito passivo para o titular do dever. É cediço, entretanto, que ambas as partes têm deveres haja vista as situações complexas - não sendo adequada a bipartição ora apontada. ${ }^{207}$

O poder familiar está muito mais para função dos pais, enquanto responsáveis pela formação dos filhos enquanto pessoa, que propriamente poder. Na

\footnotetext{
${ }^{205}$ LÔBO, Paulo Luiz Netto. Do Poder Familiar. In. Direito de Família e o novo Código Civil. Ed. Del Rey, Belo Horizonte, 2001, pág. 144.

${ }^{206}$ MARQUES, Claudia Lima; CACHAPUZ, Maria Cláudia (col.) VITÓRIA, Ana Paula da Silva (col.). Igualdade entre Filhos no Direito Brasileiro Atual - Direito Pós-Moderno? Revista dos Tribunais, São Paulo, v. 764 , 1999, pág. 15

${ }^{207}$ TEIXEIRA, Ana Carolina Brochado. Família, guarda e autoridade parental. Ed. Renovar. Rio de Janeiro, 2005.
} 
autoridade parental tanto o poder quanto o dever são dirigidos às mesmas pessoas: os pais, que devem usá-los para a concreção do princípio do melhor interesse do menor.

No que tange à natureza jurídica, alguns doutrinadores entendem que, na verdade, trata-se de um direito-função.

Do artigo 227 da Constituição Federal extrai-se o conjunto de deveres atribuídos à família, em favor do menor: o direito à vida, à saúde, à alimentação, à educação, ao lazer, à profissionalização, à cultura, à dignidade, ao respeito, à liberdade e à convivência familiar. Como podemos ver, é grande o leque dos deveres atribuídos aos pais, que decorre, justamente, do poder familiar. São estes deveres jurídicos correspondentes aos direitos cujo titular é o filho.

Roberto João Elias assevera que, "no exercício do 'pátrio poder', que se tenha em vista sua finalidade precípua, que é a de propiciar condições adequadas para o pleno desenvolvimento da personalidade da criança e do adolescente. E, então, complementa o professor: "Não se pode afirmar que o titular do pátrio poder não tem direitos, porém esses devem ser exercidos a bem dos filhos. No que se refere ao exercício, o titular pode opor seu direito em relação a terceiros, embora este tenha, como finalidade específica, o interesse do menor.",208

Na mesma linha é a orientação de Gustavo Tepedino que: "na variedade de situações que se configuram, diuturnamente, no âmbito da convivência familiar incluindo-se aí, por exemplo a fixação de domicílio e a opção por escolas e critérios pedagógicos, o limite aos poderes resultantes do pátrio poder é definido pela absoluta prioridade constitucional e legislativa dada ao desenvolvimento da personalidade do filho, a cujo interesse devem submeter-se todos os protagonistas do processo educacional"209

$\mathrm{Na}$ verdade, trata-se a autoridade parental de instituto complexo, pois há a atribuição de poderes e deveres a serem exercidos, em favor dos filhos, pelo titular do poder. Contudo não figuram os filhos como sujeitos passivos de tal relação jurídica, são, apenas, beneficiários desta. A relação parental ocorre sem que exista dominação entre os sujeitos envolvidos,

O titular não tem apenas deveres, mas direitos subjetivos, eis que, ao mesmo tempo que cumpre o seu dever de proteção e educação, beneficia-se com o desenvolvimento do filho, que é forma de realização de sua personalidade. O direito

\footnotetext{
${ }^{208}$ ELIAS, Roberto João. Pátrio Poder: guarda dos filhos e direito de visita. Ed. Saraiva, 1999, pág. 03. Observação: expressão pátrio poder utilizada pelo autor, obra escrita sob a égide do Código Civil de 1916.

${ }^{209}$ TEPEDINO, Gustavo. Temas de Direito Civil. Rio de Janeiro. Ed. Renovar, 1999, p. 426.
} 
subjetivo não se restringe, pois, aos elencados na legislação em vigor, como, o dever de obediência. São interesses que se coadunam.

E é justamente esta complexidade de atributos envolvidos na relação de parentalidade que caracteriza o poder familiar como situação subjetiva, cuja função mais relevante é a defesa do interesse dos filhos, para que desenvolvam adequadamente a sua personalidade.

\section{O EXERCÍCIO DA AUTORIDADE PARENTAL E SUAS CARACTERÍSTICAS}

O poder familiar será exercido de forma equânime e conjunta pelos pais, esta a prescrição dos artigos 226, §5 , e 229, ambos da Constituição Federal e artigo 1.631 do Código Civil.

Hoje, diferentemente do que ocorria antes da entrada em vigor da Constituição Federal, não mais existe a figura do exercício da autoridade parental única e exclusivamente pelo homem, época em que, perante o ordenamento a mulher tratava-se de mera colaboradora, sem poder de decisão.

O poder familiar, atualmente é exercido com exclusividade por um dos pais no caso de falecimento ou destituição de um deles do poder familiar - artigo 1.635, I e V, do Código Civil - ou ainda em caso de suspensão do exercício desse poder impedimento para o múnus, de acordo com o art. 1.637, caput e parágrafo único, do Código Civil.

O poder familiar concernente à filiação que tem somente a maternidade estabelecida, será exercido pela mãe, exclusivamente. Em sua falta ou impossibilidade, emerge o cabimento da tutela.

Na hipótese de dissolução da sociedade conjugal - seja pelo divórcio, separação judicial, separação de fato ou dissolução da união estável, não há qualquer alteração quanto ao poder familiar dos pais - artigo 1.632 do Código Civil -, contudo, será atribuída a um dos pais a guarda do filho menor, cabendo ao pai não guardião o direito de visitas. Por isso, não se confunde autoridade parental com guarda, a qual pode ser unilateral ou compartilhada.

Em caso de separação dos pais, não atribuída a guarda compartilhada ou conjunta, e, inexistindo acordo quanto à guarda, será esta atribuída àquele que revelar melhores condições para exercê-la. Porém, repita-se, isso não deve ser empecilho para que 
o outro, desprovido da guarda, tenha o menor em sua companhia, na medida do possível. Assim, há o direito de visita, que deve ser exercido porque é, em última instância, um direito do menor.

De fato, a convivência entre os pais não é requisito para a autoridade parental. O que pode ocorrer é a alteração da intensidade do exercício do poder familiar em decorrência de uma maior ou menor participação na vida do menor. O guardião, por certo, por estar presente no cotidiano do menor terá que em tempo integral prestar assistência moral e material - ao filho menor, cuidar, orientar, como também tomar decisões, o que implica pleno desenvolvimento do poder familiar, o não guardião, por sua vez, dependendo de sua presença e participação na vida do filho, exercerá o poder familiar com maior ou menor intensidade, especialmente quanto à educação e formação do menor.

O poder-dever de proteção e provimento das necessidades, sejam elas materiais ou espirituais, encontram abrigo muito mais na autoridade parental do que na guarda, pois ambos os pais têm a função promocional da educação dos filhos, em sentido amplo, que envolve criação, orientação e acompanhamento. Tais tarefas não incumbem apenas ao genitor guardião. ${ }^{210}$

O Código Civil estabelece que havendo separação judicial, o poder familiar permanece íntegro. A menção à separação judicial pelo legislador, deve abranger também o divórcio e a dissolução de união estável. O direito/dever de ter os filhos em sua companhia, não tendo sido estabelecida a guarda compartilhada, não exclui o do outro, conforme o decidido, amigável ou judicialmente, ao direito de visitas. Não é, pois, a convivência dos pais requisito para a titularidade do poder familiar, que apenas se suspende ou se extingue, por decisão judicial, nos casos previstos em lei.

Não obstante, algumas vezes, a convivência entre pais e filhos seja prejudicada com a separação dos pais, que, confundindo a separação conjugal com a relação com os filhos, acabam por afastar-se do convívio dos menores. Ao contrário do que orienta o ordenamento, que mantém intacta a autoridade parental e incentiva a continuidade dos laços que unem pais e filhos, após a separação.

Dissolvido o casamento, e ainda que o cônjuge constitua novo casamento ou união estável, não há qualquer restrição à autoridade dos pais (artigo 1.588, 1.589 e 1.632 do Código Civil).

${ }^{210}$ TEIXEIRA, Ana Carolina Brochado. Família, guarda e autoridade parental. Ed. Renovar. Rio de Janeiro, 2005, pág. 109. 
$\mathrm{Na}$ separação judicial, convencionam as partes quanto a guarda dos filhos, que, preferencialmente deve ser estabelecida de forma compartilhada. Não existindo consenso, atribuirá o magistrado a guarda ao cônjuge que tiver melhores condições de exercê-la. Se a separação foi pela ruptura da vida em comum, devem os filhos ficar com o cônjuge com o qual já se encontravam ao tempo da separação, e, se esta se der em razão de doença mental, os filhos ficam com quem estiver em condições de assumir a responsabilidade de sua guarda e educação.

Para o professor Roberto João Elias, "se houver separação de fato, aquele que tiver a guarda do menor exerce o poder paternal em toda plenitude, restando ao outro o direito de visita e também o de vigilância. Quem não tem a guarda não perde o pátrio poder, conquanto sejam limitados seus direitos e deveres. Trata-se, como ensina Caio Mário da Silva Pereira, de Direito de Família puro, indisponível, de sorte que não pode abrir mão dele". 211

Possível, ainda que os filhos fiquem sob a guarda de terceira pessoa, notoriamente idônea, de preferência, que seja da família, caso o juiz verifique que os menores não devam permanecer em poder da mãe nem do pai.

Contudo alerta Luiz Edson Fachin, quanto à atribuição da guarda pelos pais em caso de separação consensual que: "de um ponto de vista dos princípios jurídicos, não há nenhuma presunção segundo a qual o acordo dos pais seja conforme ao interesse da criança. No momento do divórcio, os pais, muitas vezes estão motivados por interesses pessoais e interesses econômicos e não estão em condições emocionais de encontrarem decisões determinadas pelo interesse dos filhos." 212

O poder familiar se exerce em duas searas basicamente. Uma relativa aos direitos pessoais e outra no tocante aos bens do filho.

Cabe aos pais dirigir a educação dos filhos, tendo-os em sua companhia e guarda, sustentando-os e criando-os, é o que prescreve o artigo 23 do Estatuto da Criança e do Adolescente.

Em linhas gerais, como tarefas inerentes ao poder familiar, estabelecidas pelo ordenamento, temos o dever de dirigir a criação e educação dos filhos, provendo-os material e moralmente, fornecer-lhes a possibilidade de uma formação educacional, e

${ }^{211}$ ELIAS, Roberto João. Pátrio Poder: guarda dos filhos e direito de visita. Ed. Saraiva, 1999, pág. 27. Observação: expressão pátrio poder utilizada pelo autor, obra escrita sob a égide do Código Civil de 1916.

${ }^{212}$ FACHIN, Luiz Edson. Comentários ao Novo Código Civil. Do Direito de Família. Do direito pessoal. Das Relações de Parentesco. Arts. 1.591 a 1.638. Vol. XVIII - Coord. Sávio de Figueiredo Feitosa $-1^{a}$ edição. Rio de Janeiro: Forense, 2003, pág. 233. 
como cidadãos, para que quando adultos, possam os filhos ter meios de se manter e conviver em sociedade, tê-los em sua companhia e guarda, ainda que separados judicialmente, representá-los até os 16 anos de idade e assisti-los até que atinjam a maioridade nos atos praticados na vida civil, conceder ou negar aos filhos menores consentimento para casar, nomear-lhes tutor por testamento ou documento autêntico para o caso de morte dos pais ou outra impossibilidade de exercitar o poder familiar, poder reclamar os filhos de quem ilegalmente os detenha recorrendo para tanto à busca e apreensão e, por fim, é facultado aos pais exigir dos filhos serviços próprios de sua idade e condição.

São, também, os pais os administradores legais dos bens dos filhos, dos quais tem o usufruto, contudo tais poderes de administração devem ser exercidos de acordo com os interesses dos filhos.

Assim, prescreve o artigo 1.634 do Código Civil, as atribuições inerentes ao poder familiar: "Compete aos pais, quanto a pessoa dos filhos menores: I. dirigir-lhes a criação e educação; II. tê-los em sua companhia e guarda; III. Conceder-lhes ou negar-lhes consentimento para casar; IV. Nomear-lhes tutor por testamento ou documento autêntico se o outro dos pais não lhe sobreviver, ou sobrevivo não puder exercer o poder familiar; V. representá-lo até os dezesseis anos, nos atos da vida civil, e assisti-los após essa idade, nos atos em que forem partes, suprindo-lhes o consentimento; VI. Reclamá-los de quem ilegalmente os detenha; VII. Exigir que lhes prestem obediência, respeito e os serviços próprios de sua idade e condição".

Para Paulo Luiz Netto Lôbo “a leitura das hipóteses de exercício do poder familiar está a demonstrar que significam expressão do poder doméstico, sem referência expressa aos deveres, que passaram à frente na configuração do instituto. $\mathrm{O}$ novo Código Civil é omisso quanto aos deveres que a Constituição cometeu à família. $\mathrm{O}$ ECA, quando cuida do 'pátrio poder', incumbe aos pais (art. 22) 'o dever de sustento, guarda e educação dos filhos menores' e, sempre no interesse destes, o dever de cumprir as determinações judiciais. Essa regra permanece aplicável, pois aos poderes assegurados pelo novo Código somam-se os deveres fixados na legislação especial e na própria Constituição. O dever de guarda não é inerente ao poder familiar, pois pode ser atribuído a outrem". 213

\footnotetext{
${ }^{213}$ LÔBO, Paulo Luiz Netto. Do Poder Familiar. In. Direito de Família e o novo Código Civil. Ed. Del Rey,
} Belo Horizonte, 2001, pág. 150. 
O dever de criação e educação é o dever primordial dos pais em relação aos filhos menores. Caso os genitores se omitam nesse mister, podem ser responsabilizados civil e criminalmente por abandono.

Neste sentido, a lição de Roberto João Elias: "Incumbe aos progenitores, em primeiro lugar, dirigir a criação e educação do filho, sem o que este não sobreviveria. Se houver descumprimento de tal dever, o faltoso estará sujeito às sanções da lei civil e penal. Destarte, os pais poderão responder pelos delitos de abandono material, abandono moral e intelectual (arts. 244 a 246 do CP). ${ }^{214}$

Segundo a lição de Maria Helena Diniz, os pais devem dirigir espiritual e moralmente os filhos, formando o seu espírito e caráter, aconselhando-os e dando-lhes uma formação religiosa. ${ }^{215}$

O preceito constitucional que impõe aos pais o dever de assistir, criar e educar os filhos menores deve considerar, antes de tudo, a condição peculiar da criança e do adolescente como pessoas em desenvolvimento, uma vez que a finalidade precípua do instituto é a proteção dos filhos.

Assim, leciona José Francisco Muniz: “as relações entre pais e filhos menores estão centradas na idéia de proteção. Sendo assim, o poder paternal é um regime de proteção: os pais têm o dever de assistir, criar e educar os filhos menores (...). A função do poder paternal é, portanto, assegurar os cuidados necessários para o desenvolvimento da personalidade do filho, o que compreende, também as necessidades psicológicas dos pais e a um profundo enriquecimento de suas vidas",216

O menor, antes de tudo, deve ser respeitado como pessoa em formação, especialmente pelos pais. Na educação, então, devem os pais buscar o verdadeiro interesse dos filhos, para que se desenvolvam com valores e princípios fortalecidos e então, possam se formar homens livres, com valores pessoais.

Diz Ana Carolina Brochado Teixeira que "a criação está diretamente ligada ao suprimento das necessidades biopsíquicas do menor, o que a atrela à assistência, ou seja, à satisfação das necessidades básicas, tais como cuidados na enfermidade, orientação moral, o apoio psicológico, as manifestações de afeto, o vestir o abrigar, o

\footnotetext{
${ }^{214}$ ELIAS, Roberto João. Pátrio Poder: guarda dos filhos e direito de visita. Ed. Saraiva, 1999, pág. 35.

${ }^{215}$ ELIAS, Roberto João. Pátrio Poder: guarda dos filhos e direito de visita. Ed. Saraiva, 1999, pág. 35.

${ }^{216}$ MUNIZ, José Francisco. Textos de Direito Civil. Curitiba, Juruá, 1998, p. 94.
} 
alimentar, o acompanhar física e espiritualmente". Para a autora, "está embutido no dever de assistência o dever de sustento, sendo este, portanto, inerente ao poder familiar". ${ }^{217}$

O dever de educação transcende o dever dos pais de dar uma formação ao filho em instituições educacionais. A criação e a educação dada pelos pais deve ser tal, a ponto de permitir a formação do indivíduo como pessoa, que absorveu os princípios e a cultura transmitidos no ambiente familiar, e, por conseguinte, formou sua personalidade. Em outras palavras, o poder familiar deve ser um veículo propiciador de autonomia ao menor, para que ele tenha condições de fazer suas próprias escolhas e exercer as próprias possibilidades, enfim, para que se torne um cidadão.

Bem de se dizer que criação, educação e assistência estão diretamente ligados à formação da personalidade do menor, assim como ao objetivo de satisfazer seus direitos fundamentais. A educação também diz respeito ao incentivo intelectual, para que a criança e o adolescente tenham condições de alcançar sua autonomia pessoal e profissional.

O dever de guarda e companhia inclui o dever de vigilância fazendo com que os filhos não permaneçam em más companhias, que prejudiquem o seu regular desenvolvimento, por exemplo.

Registra Roberto João Elias, quanto à necessidade de representação dos filhos que: "a representação dos filhos ocorre até que estes completem dezesseis anos, após o que, até os vinte e um, há assistência. Se o ato for praticado por menor de dezesseis anos, sem a devida representação, será nulo. Caso praticado por menor relativamente capaz, sem a devida assistência, o ato será anulado". ${ }^{218}$

E, por fim, um dos direitos a que os pais ascendem é o dever da prole de obediência e respeito.

Na seara patrimonial, têm os pais os deveres de: a) administrar os bens dos filhos menores não emancipados, sem, contudo dispor desses bens, e mesmo contrair obrigações que ultrapassem os limites da administração; b) usufruir dos bens dos filhos menores que se acham sob o seu poder, o que cessa quando da inibição do poder familiar de quaisquer dos cônjuges, com a maioridade, emancipação ou morte do filho.

Anota Luiz Edson Fachin, que, "tal como a orientação finalística do instituto, não pode esse poder ser irrestrito, posto que embora seja exercido na seara

${ }^{217}$ TEIXEIRA, Ana Carolina Brochado. Família, guarda e autoridade parental. Ed. Renovar. Rio de Janeiro, 2005, pág. 135.

${ }^{218}$ ELIAS, Roberto João. Pátrio Poder: guarda dos filhos e direito de visita. Ed. Saraiva, 1999, pág. 37. Observação, obra escrita sob a égide do Código Civil de 1916. 
privada está eivado de interesse público (embora não necessariamente estatal), do que resulta seu exercício estar necessariamente pautado na regulamentação específica e ter sempre como finalidade a proteção do filho por parte de seus pais. De modo que, qualquer atitude tomada pelos pais que transcenda essa finalidade pode ser caracterizada como abuso de autoridade, isto porque os pais desviam a finalidade deste instituto, que é a proteção dos filhos, utilizando-o indevidamente, para outros fins ou para o benefício próprio, o que não é muito difícil imaginar no tocante aos deveres relativos aos bens do filho. Basta supor que o patrimônio do menor esteja sendo utilizado em investimento de alto risco, ou ainda que esteja sendo dilapidado prodigamente por seus pais. ${ }^{219}$

São características do poder familiar a irrenunciabilidade, indisponibilidade, imprescritibilidade e a temporariedade.

Tratando-se o poder familiar de um dever-função a cargo dos pais a irrenunciabilidade é essencial, posto que, não podem eles se esquivarem ao dever de proteção dos filhos. Além disso o filho tem direito de estar inserido no seio familiar, pertencer a uma família que lhe identifique, trata-se, pois, de situação subjetiva, fonte de direitos, deveres e poderes que não dependem da mera vontade do sujeito.

É também o poder familiar indisponível, uma vez que imprescindível ao menor como fonte de assistência material e moral. "Na lição de Walter Moraes, é pelo status familiae que se confere ao indivíduo a garantia de assistência direta, apoio pessoalsocial de que ninguém pode prescindir, a não ser momentaneamente. É condição existencial, oriunda da intrínseca fragilidade e insuficiência do homem, pois este, em certos momentos da vida, não pode sobreviver sem a assistência de seus semelhantes e é certo que não há ninguém que possa viver à margem desta ordem tutelar, o que vale dizer, não há quem possa privar-se de um estado de família. Logo, é bem essencial, não se transfere e só se extingue pela morte." 220

Sendo o estado de filiação direito personalíssimo e imprescritível, como decorrência lógica, também é imprescritível o poder familiar, uma vez que, a qualquer tempo pode o filho demandar o seu estado de filiação - artigo 27 do Estatuto da Criança e do Adolescente e artigo 1.606 do Código Civil.

Enfim é temporário o poder familiar uma vez que cessa atingida a maioridade do filho, ou quando ocorrer qualquer das hipóteses dos incisos I a V do

${ }^{219}$ FACHIN, Luiz Edson. Comentários ao Novo Código Civil. Do Direito de Família. Do direito pessoal. Das Relações de Parentesco. Arts. 1.591 a 1.638. Vol. XVIII - Coord. Sávio de Figueiredo Feitosa -1 ${ }^{a}$ edição. Rio de Janeiro: Forense, 2003, pág. 221.

${ }^{220}$ ELIAS, Roberto João. Pátrio Poder: guarda dos filhos e direito de visita. Ed. Saraiva, 1999, pág. 31. 
parágrafo único do artigo $5^{\circ}$ do Código Civil: emancipação, casamento, exercício de emprego público efetivo, colação de grau em ensino superior e a existência de economia própria.

A finitude do poder familiar também se encontra na suspensão ou extinção. A suspensão retira o respectivo titular do exercício temporário do poder familiar; a extinção implica a perda definitiva.

Entre as características do poder familiar, também encontramos a indelegabilidade. O poder atribuído aos pais pelo artigo 1.631 do Código Civil, por tratar de ônus atribuído pela sociedade, não pode ser objeto de renúncia. Não pode também, tal função ser delegada. Não se admite, na hipótese, interposição, representação ou abdicação.

Como já ressaltado, o poder familiar é um instituto complexo, que deve ser exercido em prol do menor, com o intuito de protegê-lo, observando-se o seu melhor interesse, para propiciar o seu pleno desenvolvimento. Mas, é certamente, nesta troca entre pais e filhos, que se dá a realização pessoal de todos os membros do grupo familiar, onde cada um enxerga um pouco de si no outro.

Vemos, então, que o poder familiar, acima de tudo é um instituto que se concretiza do cotidiano familiar, baseado na solidariedade e no afeto, não sendo, nesta relação, a titularidade primordial para que se verifique a autoridade parental.

Assim, a lição da professora Giselda Maria Fernandes Novaes Hironaka, “Conceber as famílias como associações determinadas pelo afeto significa necessariamente recusar que sejam determinadas por uma relação de dominação ou poder. Paralelamente, significa dar a devida atenção às necessidades dos filhos em termos, justamente, de afeto e proteção. Poder-se-ia dizer, assim, que uma vida familiar na qual os laços afetivos são atados por sentimentos positivos, de alegria e amor recíprocos em vez de tristeza ou ódio recíprocos, é uma vida coletiva em que se estabelece não só a autoridade parental e a orientação filial, como especialmente a liberdade paterno-filial. Uma vida familiar que, ao contrário, é marcada pelas relações de ódio é claramente uma vida na qual se perdeu qualquer equilíbrio afetivo, porque já não se percebem, aí, identidades, semelhanças, generosidades.",221

${ }^{221}$ HIRONAKA, Giselda Maria Fernandes Novaes Responsabilidade civil nas relações paterno-filial. In. Rodrigo da Cunha Pereira (coord) Família e cidadania: o novo CCB e a vacatio legis, Belo Horizonte, Del Rey, 2002, p. 430. 
A comunhão de vida no âmbito familiar se consolida justamente desta colaboração mútua entre os integrantes. É daí que afloram os sentimentos de reciprocidade e solidariedade entre os membros da família, especialmente entre pais e filhos.

Nestas circunstâncias, perdeu o poder familiar a característica de instituo patrimonializado para ostentar, cada vez mais, seu aspecto existencial, sua essência de função em prol da família, em consonância com a atual família solidarista, cujo maior valor é o afeto. Os laços estabelecidos no âmbito familiar, tornam-se, então, cada vez mais relevantes como fonte de afetividade e realização da dignidade de pais e filhos, que a cada dia, crescem e aprendem uns com os outros.

Neste sentido a lição de Marcos Alves da Silva: "na nova família, a autoridade parental menos que uma titularidade, constitui-se e mantém-se pelos efetivos e afetivos laços que unem pais e filhos. A Constituição de 1988 fixou marco referencial em matéria de direito de filiação. Desatrelada do matrimônio, a relação paterno-filial foi tutelada como um bem em si. As diversas circunstâncias que impõe a separação entre pais e filhos, as possibilidades de investigação de paternidade e a pluralidade de formas de constituição de entidades familiares apontam na direção de que a autoridade parental não deriva meramente de um título de registro de nascimento, nem tampouco do simples reconhecimento de vínculo genético entre progenitor e gerado, decorrendo, antes e sobretudo, da real existência da posse de estado de filho."222

No âmbito da família, a busca de realização pessoal vai engendrar um contínuo movimento de seus membros, que, através da convivência, estabelecerão como se dará na prática a relação de autoridade no ambiente familiar. Tal percepção insere a noção própria de direito subjetivo que eleva à dignidade de titulares tanto pais quanto filhos.

E, quanto à importância sobre a forma que se dá este relacionamento no ambiente familiar, ressalta Giselle Câmara Groeninga que "por meio da convivência é que se forma a nossa subjetividade, a nossa identidade e a nossa identidade sexual, além do reconhecimento das diferenças, mais do que simplesmente a questão das diferenças biológicas. Somente por meio da convivência é que desenvolvemos relações afetivas. Se não tivermos afeto, podemos até morrer. ${ }^{223}$

\footnotetext{
${ }^{222}$ SILVA, Marcos Alves da. Do pátrio poder à autoridade parental: repensando fundamentos jurídicos da relação entre pais e filhos, Rio de Janeiro. Renovar, 2002, p. 197.

${ }^{223}$ GROENINGA. Giselle Câmara. Afetos, sexualidade e violência - A família desmistificada. In. DIAS, Maria Berenice e BASTOS, Eliene Ferreira. Família além dos mitos. Ed. Del Rey, Belo Horizonte, 2008, pág. 78.
} 
Assim, sendo a família, na sociedade contemporânea, plural quanto a sua origem e formação, diversos serão os arranjos familiares possíveis, com distintas figuras de autoridade. Por esta razão, a noção da família tradicional, com a autoridade centrada na figura do pai já não funciona. Não obstante a figura da autoridade, na maioria dos lares, esteja nos pais, pode ocorrer de um avô ou uma avó representar tal figura, ou até mesmo um tio, quando não, o novo cônjuge ou companheiro da mãe o seja.

Por esta razão, a solidariedade também é valor jurídico, que deve ser adotado pelo Direito de Família. O momento histórico e social exige, em favor das crianças e dos adolescentes, o papel construtivo tanto da jurisprudência quanto da doutrina, desafiadas pela força dos novos fatos sociais..

Como se demonstrará, no capítulo seguinte, possível o exercício da parentalidade, nas famílias reconstituídas, pelos pais afins, uma vez que, tendo a família como base a afetividade e a solidariedade, esvaziado o seu conteúdo biológico, os laços de sangue, por si sós, não garantem o melhor interesse da criança. 


\section{VII - AUTORIDADE PARENTAL NAS FAMÍLIAS RECONSTITUÍDAS}

\section{O EXERCÍCIO DA AUTORIDADE}

Com acerto, o legislador de 2002, no artigo 1.636 do Código Civil distingue o poder familiar do estado civil dos pais. Da leitura do dispositivo, denota-se a compreensão pelo legislador da pluralidade familiar, protegida constitucionalmente, seja ela matrimonial, monoparental, constituída pela união estável, e, especialmente, se reconstituída, por pessoas que, após o término de um relacionamento, seja pela morte, separação, divórcio ou dissolução de união estável, novamente se unem a outras para formar um novo núcleo familiar.

Registra Luiz Edson Fachin, quanto ao dispositivo em comento que, “novo casamento ou nova união estável funda situação jurídica decorrente das expressões diversas e variadas do afeto do homem ou da mulher; a autoridade parental (poder familiar, na expressão do Código Civil de 2002) é inerente ao vínculo familiar que, entre pais e filhos (e vice-versa), não se altera com a mudança que pode ocorrer no relacionamento do pai ou da mãe. A regra em comento não abarca tão-só a alteração mas, também, a constituição (solteiro que casa ou passa a viver em união estável)". ${ }^{224}$

Dentro desta nova tendência do Direito de família, com preferência do afeto sobre a moral, nascem novos institutos, como a parentalidade afetiva. Reconhecida pela melhor doutrina, a parentalidade socioafetiva, tem como base a posse de estado de filho, e, na maioria das vezes está presente nas famílias reconstituídas, o que permite a desvinculação dos laços de sangue na plena realização das atividades parentais.

Buscando a realização pessoal, o ordenamento foi posto em segundo plano e os sujeitos se impuseram como prioridade. Formaram-se novas famílias, marginais e excluídas do mundo jurídico, mas ainda assim se formaram. A verdade social não se ateve à verdade jurídica e os fatos afrontaram o Direito. Valorizada a pessoa, valorizados também seus sentimentos e interesses conquistados na concretização do afeto e da solidariedade dentro do ambiente familiar.

A convivência gera vínculos familiares em que se observa o comprometimento mútuo dos integrantes, decorrente da afetividade. A família é, pois, uma

\footnotetext{
${ }^{224}$ FACHIN, Luiz Edson. Comentários ao Novo Código Civil. Do Direito de Família. Do direito pessoal. Das Relações de Parentesco. Arts. 1.591 a 1.638. Vol. XVIII - Coord. Sávio de Figueiredo Feitosa -1 ${ }^{a}$ edição. Rio de Janeiro: Forense, 2003, pág. 255.
} 
estrutura de cuidado e proteção, mas, não é só, também implica socialização dos integrantes para que possam se desenvolver como membro de seu grupo social. Cuidados que podem ser exercidos nas mais diversas estruturas familiares.

Neste sentido, registra Waldyr Grisard Filho que, "circula na sociedade a idéia generalizada de que somente o laço de sangue possibilita o pleno exercício da parentalidade. Por isto, não fundado o nexo entre um cônjuge e os filhos do outro no vínculo sanguíneo, atribui-se ao pai ou a mãe afim uma incapacidade para os cuidados do filho afim. Decorre disto, que não teriam direitos a atuar. Contudo, anota João Baptista Villela, as transformações por que passou a família, de unidade de caráter econômico, social e religioso, para se afirmar como grupo de afetividade e companheirismo, imprimiram considerável reforço ao esvaziamento biológico da paternidade, passando-se a reivindicar uma parentalidade psicológica e social. Nesta perspectiva, a função parental pode bem ser cumprida pelos pais afins. Os laços de sangue, por si sós, não garantem o melhor interesse da criança." 225

A criação e a educação, tarefas inerentes à autoridade parental, como visto, são valores transmitidos ao menor no cotidiano, especialmente dentro do ambiente familiar. Contudo não é atribuição exclusiva dos pais, uma vez que, o filho, na formação de sua personalidade, convive com outras pessoas, que não os pais, que, complementarmente, também exercem tal atribuição, tal como avós, tios, professores, babás, etc.

O fundamental é que as pessoas que exerçam tais funções sejam capazes de exercê-las com amor e respeito.

Se o desenvolvimento do menor é reflexo do ambiente familiar, todos que circulam naquele ambiente, de uma certa forma, influenciam. Logo há de se concluir que nas famílias reconstituídas, onde convivem pai e mãe com filhos de diferentes uniões, impossível que não haja interferência direta ou indiretamente, na criação e educação daquele menor.

Rodrigo da Cunha Pereira, em seu diálogo entre Direito e Psicanálise, ensinou que, para a estruturação de uma pessoa, é necessário que alguém cumpra funções paternas e maternas em sua vida, que poderá ser, ou não os pais biológicos. Por isso, a família não é um agrupamento natural, mas cultural, pois ela sobrevive independentemente dos vínculos biológicos existentes entre seus membros. Essa é uma das justificativas pela

${ }^{225}$ GRISARD FILHO, Waldyr. Famílias reconstituídas. Novas uniões depois da separação. Ed. Revista dos Tribunais. São Paulo, 2007, pág. 129. 
impossibilidade de limitar as formas de família, pois, na contemporaneidade, ela é plural. $^{226}$

Sob a ótica da psicanálise, destacamos a importância da transmissão da cultura dentro da família, na formação de seus integrantes. A linguagem e as tradições são referências como a primeira lei que dá identidade ao homem. Quando a criança começa a falar e a ela se refere - eu -, constitui-se como sujeito de direitos. Esta a primeira lei, baseada na relação entre os homens, ou seja, é uma lei que funda a nossa estrutura psíquica, que nos permitirá nos relacionarmos. A primeira integração se dá no ambiente familiar, onde, então, nos estruturamos e nos desenvolvemos, para nos integrar à sociedade.

Para Giselle Câmara Groeninga, "é por meio da identificação com os pais como modelos e da vivência afetiva com eles, e da oscilação entre amor e ódio, com um e com outro, que nos tornamos seres humanos capazes de dirigir nossas emoções, impulsos e sentimentos para fins socialmente aceitáveis. É com os pais, por meio da oscilação afetiva, entre amor e rivalidade, que desenvolvemos a nossa identidade que, sem dúvida alguma, está ligada também à nossa sexualidade, à nossa forma de viver as diferenças. Vejam que estou falando da sexualidade como forma de viver as diferenças. Essa não se restringe à questão da sexualidade biológica e adulta - genital. O que define uma família é justamente a diferença entre lugares e funções. São assimétricas as relações de família e, o que é importantíssimo, as suas funções são complementares. Quando falamos em função materna, paterna e de filhos, essas funções sempre pressupõe serem complementares. Assim é a noção de função, mesmo que a presença do pai ou da mãe seja virtual.” 227

Destarte, somente com a transmissão destes valores dentro do ambiente familiar a formação do indivíduo será plena.

As crianças e os adolescentes precisam de uma mãe e de um pai, disso não há dúvida. Porém, com a dissolução da sociedade conjugal ou a dissolução da união estável, ficando o menor sob a guarda de um dos pais, naturalmente surgirá uma lacuna funcional, mesmo que a outra parte (pai ou mãe que saiu do convívio diário familiar) mantenha-se a par dos acontecimentos, mesmo que compartilhe a guarda do menor. $\mathrm{O}$ fato é que os eventos acontecem no dia a dia, na operação da entidade familiar, e se o pai ou a

${ }^{226}$ TEIXEIRA, Ana Carolina Brochado. Família, guarda e autoridade parental. Ed. Renovar. Rio de Janeiro, 2005 , pág. 126.

${ }^{227}$ GROENINGA. Giselle Câmara. Afetos, sexualidade e violência - A família desmistificada. In. DIAS, Maria Berenice e BASTOS, Eliene Ferreira. Família além dos mitos. Ed. Del Rey, Belo Horizonte, 2008, pág. 72. 
mãe não estão no dia a dia, fica impossível a manutenção da sensibilidade que o pai ou a mãe precisam ter para agirem no momento e na dose adequadas a cada caso concreto da vida do menor.

É relevante também a questão da oportunidade, resolver a questão que surge no ato, no momento em que as coisas acontecem. Na prática, as tarefas corriqueiras de fundamental importância para uma saudável operação familiar, naturalmente são realizadas pelo outro cabeça do casal da família reconstituída, os pais afins.

Como estudado no capítulo referente às relações paterno-filiais, os pais, para os filhos menores, são muito mais importantes enquanto executores de uma função, buscando o seu pleno desenvolvimento, do que como referência biológica. Evidente, que os pais afins, enquanto autoridade dentro do ambiente familiar, querendo ou não, irão desenvolver funções parentais, seja transmitindo valores, seja nos cuidados domésticos, seja opinando, o que variará de uma família para a outra, será tão somente a intensidade deste exercício.

Neste sentido, Maria Christina Almeida, defende ser a paternidade e a maternidade muito mais uma função do que uma ligação específica ao ascendente biológico. Por isso, o reconhecimento de situações fáticas representadas por núcleos familiares recompostos traz novos elementos sobre a concepção de paternidade, compreendendo, a partir deles, o papel social do pai e da mãe, desvinculando-se do fator meramente biológico e ampliando seu conceito, realçando sua função biopsicossocial. ${ }^{228}$

A doutrina italiana, orienta que as relações de poder familiar devem se dar no melhor interesse do menor, independentemente dos laços de sangue, e assim, dispõe que “(...) l'istituto há travalicato i confini della famigilia di sangui, sulla quale traeva fondamento l'autorità del genitore, per estendersi a tutte Le situazioni in cui è necessária la cura del minori”,229

O convívio familiar, neste caso, é que orienta a autoridade parental, de acordo com o melhor interesse do menor.

Leciona Ana Carolina Brochado Teixeira: "Constata-se, destarte, a possibilidade da transferência de parte do exercício do poder familiar ao pai ou à mãe afim

\footnotetext{
${ }^{228}$ ALMEIDA, Maria Christina. A Paternidade Sócioafetiva e a Formação da Personalidade. O Estado e os Estados de Filiação. Revista Jurídica Del Rey, Belo Horizonte : Del Rey/IBDFAM, 2002, n. 8, p. 24, maio 2002. (Número especial).

${ }^{229}$ CIAN, Giorgio. OPPO, Girogio, TRABUCCHI, Alberto. Comentario al diritto italiano della famiglia. Padova, Cedam, 1992, v. 4, p. 301. Tradução livre: o instituto transcendeu as fronteiras da família de sangue, sobre a qual se fundava na autoridade do genitor, para estender-se a todas as situações nas quais é necessário o cuidado do menor.
} 
mediante autorização do titular. Assim, o genitor afim poderá contribuir de forma decisiva para os deveres de criar, assistir e educar os filhos menores, previstos no art. 229 da Constituição Federal. Poderá exercer as funções maternas ou paternas na vida da criança e do adolescente, que será, certamente, decisivo para sua estruturação biopsíquica saudável, enquanto pessoa. Poderão vivenciar a posse de estado, mediante o surgimento e fortalecimento da afetividade entre os integrantes da família, inclusive aprendendo a administrar os conflitos naturalmente surgidos". 230

Evidente que, tratando-se de situação complexa, a administração de interesses, visando ao equilíbrio dentro do ambiente familiar, é indispensável à estabilidade da família. Os pais biológicos e afins devem procurar ser coerentes em suas ações visando a uma harmonia familiar.

O desafio do casal no exercício da autoridade parental nas famílias reconstituídas é enorme por conviverem crianças de diversos relacionamentos que terão que se adaptar ao novo grupo, que criará suas próprias regras de conduta.

Contudo o lugar ocupado pelos pais e mães afins depende, muitas vezes, da origem da família reconstituída, se os pais biológicos do relacionamento anterior estão presentes ou não e da idade das crianças, como adiante se demonstrará.

\section{ATUAÇÃO SUBSIDIÁRIA DOS PAIS AFINS}

O convívio pressupõe integração. É inevitável, pois, a participação do cônjuge ou companheiro afim nas tarefas inerentes ao poder parental, pois ele convive diariamente com o filho, participando de quase todos os momentos de sua vida, seja nos momentos de alegrias, de tristezas, de diversão, de cumprimento de deveres ou, de conflitos.

Ainda que procure o cônjuge ou o companheiro se afastar das decisões quanto ao filho exclusivo do outro, as atividades diariamente desenvolvidas dentro do ambiente familiar necessitam que a todo tempo sejam tomadas decisões que dizem respeito ao grupo familiar, e, frequentemente, o responsável por estas decisões, não será necessariamente o genitor daquele menor. Isto porque, o cônjuge ou companheiro do pai ou da mãe simboliza a outra autoridade dentro do ambiente familiar.

\footnotetext{
${ }^{230}$ TEIXEIRA, Ana Carolina Brochado. Família, guarda e autoridade parental. Ed. Renovar. Rio de Janeiro, 2005, pág. 125/126.
} 
Para Ana Carolina Brochado Teixeira, "não há dúvida, portanto, quanto à possibilidade de exercício da autoridade parental pelo genitor afim, mediante autorização do titular. Essa, muitas vezes, é feita de forma inconsciente e tácita, através de permissões sucessivas, ou mesmo em pequenos pedidos de auxílio com a educação do filho, que pode se dar nas mínimas tarefas do quotidiano, ou nas grandes decisões acerca da educação, da escolha da escola mais adequada, ou mesmo na disciplina do filho. Entretanto, se houver algum problema com essa delegação, o responsável deve ser o genitor biológico, desde que o afim tenha agido de boa-fé. Não há fórmulas predeterminadas para o êxito desses novos arranjos, pois criar filhos é um verdadeiro desafio, seja pelo pai afetivo, biológico ou adotivo. Não se tem garantia do resultado, apenas das tentativas de acerto, que são feitas permeadas pela afetividade que medeia a relação parental, seja biológica ou não." 231

Nas famílias de primeiras uniões, as atribuições do poder familiar, são bem definidas e conhecidas por todos. Nas famílias reconstituídas, ao contrário, em que convivem crianças e adolescentes de diversos relacionamentos, não existem regras prédeterminadas que orientem as condutas de pais e mães afins em relação a seus filhos afins.

A família reconstituída, enquanto união de pessoas que têm um ou mais filhos de uniões anteriores, não se funda sobre condições naturais, mas sociais. E, como tal, representa nova estrutura familiar, não obstante, alheia à regulamentação pelo ordenamento jurídico. De forma relevante, então, se caracteriza como mais um momento evolutivo no ciclo das formas familiares, concebe nova forma de parentalidade.

A família, hoje, dentro do contexto pluralista, deve ser vista como instrumento para o desenvolvimento da personalidade de seus integrantes, não importando se se distancia do modelo institucional, desde que contribua para a realização da dignidade dos seus participantes.

As famílias reconstituídas podem ter várias configurações, tais como a) o genitor, seu filho e o novo companheiro ou cônjuge, sem prole comum; b) o genitor, seu filho e o novo companheiro ou cônjuge, com prole comum; c) os genitores de famílias originárias distintas e seus respectivos filhos, inexistindo prole comum; os genitores de famílias originárias distintas e seus respectivos filhos, com prole comum. Neste sentido, possível imaginar a variedade de arranjos familiares que necessitam de regramentos distintos. O grande número de possíveis origens destas famílias e o acúmulo de vínculos

\footnotetext{
${ }^{231}$ TEIXEIRA, Ana Carolina Brochado. Família, guarda e autoridade parental. Ed. Renovar. Rio de Janeiro, 2005, pág. 128.
} 
interindividuais que nelas se formam, por si sós, já demonstram a complexidade do instituto.

Este grupo familiar, proveniente do novo matrimônio ou união do genitor no exercício da guarda de seus filhos havidos de uma união anterior, conforma um sistema familiar único, mas, tal como a estrutura tradicional não está isenta das mesmas preocupações e conflitos.

Assim, registra Waldyr Grisard Filho: "as famílias reconstituídas, embora possuam as mesmas características de qualquer família, como a socialização dos filhos, a afetividade, a mútua assistência moral e material, a proteção, possuem outras especiais, que as distingue das famílias originais: é uma estrutura complexa, formada por múltiplos vínculos e nexos; existe ambigüidade nas regras; conseqüência desta são os conflitos originados na oposição entre as atitudes manifestas e os desejos encobertos, produto da falta de clareza nos lugares e direitos e deveres de seus integrantes; a interdependência requer combinar-se com os subsistemas anteriores e, por conseguinte, é necessário articular-se os direitos e os deveres dos integrantes do novo núcleo com os direitos e deveres dos integrantes daqueles subsistemas. Igualmente devem harmonizar-se alguns direitos do cônjuge atual e do ex-cônjuge, notadamente a autoridade parental e os alimentos, além de outras obrigações que afetam os filhos." 232

São complexas as relações estabelecidas no âmbito da família reconstituída. Em primeiro lugar porque cada participante da nova família traz consigo uma história própria, circunstância que exige tempo para realizar seu próprio ajuste mediante a reformulação de expectativas e necessidades em relação à nova situação. E depois, especialmente com relação aos filhos das uniões anteriores, que deverão se submeter a regras e estilos de parentalidade distintos.

Porém não há estabelecimento institucional que oriente o comportamento dos pais e mães afins em relação aos filhos afins. O novo marido da mãe, por exemplo, não sabe se se comporta como um "pai", "um tio", "um amigo" ou "um outro adulto da casa", especialmente, porque as categorias filhos, pais e mães afins, não são excludentes e nem contrárias às figuras nucleares tradicionais, mas complementares. Daí nascem os conflitos, das expectativas de comportamento.

Nestas famílias circulam e convivem crianças e adolescentes de distintos casamentos e uniões estáveis, não é, pois, difícil de imaginar que o sustento emocional e

${ }^{232}$ GRISARD FILHO, Waldyr. Famílias reconstituídas. Novas uniões depois da separação. Ed. Revista dos Tribunais. São Paulo, 2007, pág. 90. 
material do grupo passa por diversos conflitos, especialmente de princípios e regras, quanto ao exercício da autoridade parental.

Para existir uma convivência pacífica é necessário que exista um profundo respeito pela individualidade, história e o lugar agora ocupado por cada um dos integrantes do novo grupo. O casal, deve então discriminar atitudes egoístas, de ciúmes e inveja, como também promover a coesão e o entendimento entre os integrantes, ressaltando, especialmente, a necessidade de respeito ao espaço de cada um.

A tarefa não é fácil.

Registra Waldyr Grisard Filho, "a família, como grupo social, desde o modelo arcaico, requer pautas de conduta que definam e compatibilizem as regras entre seus integrantes, sem as quais não se pode conceber seu funcionamento. De uma maneira mais crescente, as famílias reconstituídas vivem seu cotidiano essencialmente no espaço privado e à margem da lei, com pautas institucionais somente para alguns de seus integrantes. Por inexistirem normas externas, são seus próprios integrantes que as criam. Para isto, exige-se o intercâmbio e a concordância de todos os membros da família, como meio de legitimar as regras que não são institucionalizadas. A falta de legitimação enraíza o medo e com ele as rivalidades, os interesses extremados e as chantagens afetivas. Ao direito cabe legitimar as eleições individuais ou grupais, afirmar certas responsabilidades originadas nas funções familiares, instituir determinadas regras para impedir descumprimento das funções conjugais e parentais." ${ }^{233}$

Da mesma forma, Ana Carolina Brochado Teixeira, diz: "note-se que a escassa doutrina existente considera esta espécie de família apenas quando existem filhos de um ou de ambos os cônjuges ou companheiros, que passam a conviver com o outro. Formam um novo lar com regras próprias, no qual cada um traz consigo a experiência vivida na família anterior. Diante dessa diversidade, a única alternativa é a criação de uma nova forma de convivência, através da qual os membros possam co-existir em busca da harmonia no novo arranjo familiar." 234

Como já dito, os pais afins assumem responsabilidades quanto aos filhos de seu companheiro ou cônjuge muito antes de se estabelecerem vínculos emocionais. Então, enfrenta-se o primeiro problema dentro do grupo familiar, como será o comportamento dos adultos em relação aos filhos do outro quanto ao lugar que ocuparão

${ }^{233}$ GRISARD FILHO, Waldyr. Famílias reconstituídas. Novas uniões depois da separação. Ed. Revista dos Tribunais. São Paulo, 2007, pág. 100.

${ }^{234}$ TEIXEIRA, Ana Carolina Brochado. Família, guarda e autoridade parental. Ed. Renovar. Rio de Janeiro, 2005, pág. 120. 
naquela família. Por exemplo, a nova mulher do pai que pretende atuar como mãe, mas os filhos não reconhecem nela a autoridade de "mãe", ou então, o marido que pretende se manter ausente das decisões relativas aos filhos de sua mulher. Ou ainda, podemos encontrar situações em que há um descompasso nas etapas de vida dos cônjuges ou companheiros, por exemplo, um dos cônjuges possui filhos adolescentes e o outro, que não possui filhos, de repente se vê responsável por este adolescente, ou então, um dos cônjuges, possui filhos pequenos, enquanto o outro, já criou todos seus filhos e já é avô, se vê responsável por crianças, nesta etapa da vida.

Contudo é extremamente importante para a criança a presença das figuras paternas e maternas para a criança, ainda, que gere conflitos de lealdade, é melhor a criança ter dois pais a não ter a sua figura.

É em razão disto que Cecília P. Grosman e Silvia Mesterman afirmam: "Se a criança não pode viver com os dois pais biológicos, é melhor que conviva em lar recomposto e não em uma família de um só dos pais". E, em igual sentido, observa Françoise Dolto: “A situação triangular é sempre preferível para a criança. É melhor, para as crianças de ambos os sexos, que a mãe volte a formar um casal, sobretudo se, por seu lado, o pai viver sozinho. Da mesma forma, é melhor para as crianças de ambos os sexos que o pai tenha uma parceira, mas principalmente para o menino, quando a mãe vive sozinha". 235

Embora tenham as famílias reconstituídas sofrido com a separação anterior, de pelo menos um dos cônjuges ou companheiro, tenham as crianças vivenciado a ruptura de um lar, a formação de uma nova família, como vimos, reintegra o menor no seio de um lar, lhe traz novas referências da figura materna e paterna, o que lhe traz benefícios.

Pais e mães afins podem ser figuras benéficas aos menores, podem lhe trazer o aprendizado de novas e sadias formas de relacionamento. Os conflitos surgirão, não há dúvidas. Podem existir fases de negação, de hostilidade, de confronto.

Mas, é certo que esses conflitos só podem ser resolvidos no seio familiar, por comum acordo, uma vez que a lei não cria ou impõe sentimentos. Com o tempo, aquele novo grupo familiar criará suas próprias regras, fruto da convivência, às quais os participantes se adaptarão. Com o tempo haverá a aceitação e, em muitos casos, a formação de um vinculo sincero de afeto. No entanto poderia e pode a lei legitimar comportamentos e responsabilidades livremente assumidos.

${ }^{235}$ GRISARD FILHO, Waldyr. Famílias reconstituídas. Novas uniões depois da separação. Ed. Revista dos Tribunais. São Paulo, 2007, pág. 89. 
Nas famílias reconstituídas uma das grandes inquietações que surgem para os pais afins diz respeito ao papel que assumirão dentro do ambiente familiar. Quem será provedor de quem? Quem cuidará dos afazeres domésticos? Quem estipulará as regras para o convívio diário? Pode a mulher unida a um homem que não vive com seus filhos o exercício de quaisquer dos atributos do poder familiar em relação a estes filhos? Pode dirigir-lhes a criação e educação, bem assim exigir-lhes respeito e obediência e a prestação de serviços próprios de sua idade e condição? Pode assistir e representar os filhos de seu novo marido, nomear-lhes tutor ou reclamá-los de quem ilegalmente os detenha?

Não existem respostas a estas perguntas no nosso ordenamento e, o que é pior, nada há que legitime sua conduta em relação aos filhos afins, ainda quando existam laços estreitos unindo os integrantes daquela família. A conduta dos pais afins, portanto, é puramente instintiva, trata-se de obrigação natural e compromisso moral em razão da convivência.

Neste contexto, questiona, Ana Carolina Brochado Teixeira: "Com o casamento ou a união estável de duas pessoas, que levam para o novo lar um ou mais filhos de relações anteriores - seja em decorrência da viuvez, separações, divórcios, dissoluções de uniões estáveis ou pai e mãe solteiros que criam sozinhos seus filhos -, há o estabelecimento de um conjunto próprio de regras de convivência para aquela nova família, principalmente no que se refere à continuidade da criação e educação dos filhos. Isso porque o espaço de liberdade de cada um sofre interferências em decorrência das novas pessoas que se agregam àquele núcleo familiar. Assim, o conflito acontece, principalmente quando não há definição prévia dos espaços e dos papéis de cada integrante dentro deste arranjo familiar. É neste contexto que surgem inúmeros questionamentos: a convivência, o quotidiano possibilitam a interferência do novo cônjuge ou companheiro na criação do filho? Em caso afirmativo, qual o limite dessa intervenção?”, 236

A convivência faz gerar inúmeras situações, envolvendo a família sendo impossível que o novo "marido" ou "mulher" simplesmente se mantenha alheio a respeito das decisões relativas aos filhos de seu cônjuge ou companheiro.

Uma pesquisa realizada por Daniel Kauffman ${ }^{237}$, “A família reconstituída paulistana e seu ciclo vital: uma análise na perspectiva das mudanças no ciclo da vida

${ }^{236}$ TEIXEIRA, Ana Carolina Brochado. Família, guarda e autoridade parental. Ed. Renovar. Rio de Janeiro, 2005, pág. 120.

${ }^{237}$ KAUFFMAN, Daniel. A Família reconstituída e o seu ciclo vital: uma análise qualitativa dos seus perfis. Monografia apresnetada ao Programa de Iniciação Científica, Faculdade de Psicologia, Universidade Presbiteriana Mackenzie, São Paulo, 2000. 
familiar”, através de uma bolsa de Iniciação Científica proporcionada pela Fundação de Amparo à Pesquisa do Estado de São Paulo (FAPESP), de duração de um ano e meio, com 50 famílias reconstituídas, de classe média paulistana, com aplicação de questionários com questões referentes à identificação, estrutura dinâmica e valores, detectou que as relações estabelecidas entre 'enteados' e 'padrastos' ou 'madrastas' era, no mínimo de respeito.

Tal fato, demonstra que a posição ocupada pelos pais afins é relevante dentro da família e que os menores, neles enxergam uma figura que representa autoridade dentro do ambiente familiar. Motivo pelo qual, sua conduta deve ser legitimida, em prol não só do interesse do grupo familiar e seus arranjos, mas, especialmente do menor.

Cumpre esclarecer, no entanto, que a origem da família reconstituída influencia no papel dos pais afins, pois se o pai biológico faleceu o pai afim poderá mais facilmente exercer o papel de "pai”, preenchendo um vazio na vida daquele menor, entretanto, quando a família reconstituída é proveniente da separação dos pais biológicos, a atuação do pai afim será diferente e complementar, dependendo do grau de atuação do pai biológico.

\subsection{ATUAÇÃO DOS PAIS AFINS QUANDO OS PAIS BIOLÓGICOS} SÃO ATIVOS

Se os pais biológicos são ativos, os pais afins não substituem e nem devem substituir estes, principalmente se a participação for efetiva na criação e educação do menor. Se ausentes, pode dar-se a lógica substituição por se encontrar vago o lugar do pai.

Desta forma, quando a família se reconstitui em razão de uma separação, divórcio ou dissolução de união estável anterior e os pais biológicos são ativos na criação e educação de seus filhos, as funções dos pais afins são de complementaridade, exigindo conciliação entre estes. Não é possível definir de maneira precisa quais atividades têm os pais afins direito de realizar, mas por certo estarão ligadas à vida cotidiana e à dinâmica doméstica.

Não obstante complementaridade não designa atuação em segundo plano, mas integração no exercício da parentalidade. É positivo para o desenvolvimento dos filhos, pois supre carências dos pais biológicos. A expressão "função subsidiária" dos pais afins é justamente utilizada no sentido de ajudar, contribuir, complementar e reforçar. 
Por certo, nestas situações, ainda que mantidos os laços originais de paternidade, não há como ignorar o exercício da autoridade parental pelos pais afins, uma vez que, a convivência familiar pressupõe a transmissão de valores e princípios e a participação na vida do grupo. Do mesmo modo, tratando-se o cônjuge ou companheiro do pai ou da mãe, do outro adulto da casa, em diversas situações cotidianas, desde os cuidados com a alimentação e outras tarefas domésticas até o socorro em caso de algum acidente, será o pai ou mãe afim que atuará como autoridade dentro do ambiente familiar.

É óbvio que nesta situação a atuação é subsidiária, com vistas a integrar a parentalidade, auxiliando no desenvolvimento do menor, sendo, pois, limitada pelo cônjuge ou companheiro genitor. As relações, nestas circunstâncias, exigirão constantes esforços dos participantes, visando à conciliação na conduta das relações entre pais e filhos, biológicos e afins.

Por exemplo, a mãe, que normalmente exerce a função de conciliadora responsável pelos cuidados emocionais, pela mediação entre os relacionamentos familiares - terá a difícil tarfea de ao mesmo tempo assumir este papel no ambiente familiar e preservar o da mãe biológica.

Neste sentido, a lição de Waldyr Grisard Filho: “quando, ambos os pais biológicos são ativos na criação e educação de seus filhos, as funções do pai ou mãe afim serão de complementaridade, exigindo maior conciliação entre eles, cujo conteúdo não se define em termos absolutos. Não será possível estabelecer de forma clara e precisa quais as atividades concretas que têm direito a realizar, mas é certo que serão ações ligadas à vida cotidiana e ao funcionamento doméstico. Complementaridade não significa mera acessoriedade, mas integração da função, suprimindo o paradigma da exclusividade do exercício parental. (...) Portanto, esta função adicional, não de substituição, pode ser compartilhada com outras pessoas - geralmente com avós, tias, babás, professoras, pais e mãe afins -, quer dizer, não é exclusiva e resulta positiva para o desenvolvimento dos filhos na medida em que o exercício parental do pai ou mãe afim enriquece ou compensa as carências vinculares. Em qualquer caso, o pai e a mãe afim terão influência na socialização dos filhos de seu cônjuge ou companheiro, preparando-os para a vida de relação, o que implica diversos cuidados, sustento, educação, saúde, transmissão de normas e valores, modelos de conduta. Estes cuidados, embora ativos os pais biológicos, não permite descartar a cooperação de fato de quem vive com o pai ou a mãe biológicos. A só 
coabitação com o pai ou mãe afim propicia a participação na função formativa da criança e do adolescente, ainda quando não conscientemente decidida."238

De fato, a convivência sob um mesmo teto exige organização familiar empenhada para o bem-estar comum. Para tanto, é necessário o estabelecimento de um regramento de hábitos e atividades, pelo genitor e pelo pai ou mãe afim, considerando os interesses dos menores. De rigor, pois, conferir ao pai ou mãe afim certa autoridade no âmbito doméstico, proveniente da convivência e da responsabilidade de todo adulto sobre menor a seu encargo.

\subsubsection{ESTABELECIMENTO DO VÍNCULO COM OS PAIS AFINS} EM RAZÃO DA IDADE

Constata-se também, diferença na qualidade do vínculo, se a relação se estabelece com crianças em tenra idade ou já na fase da adolescência.

Quando pequenas, as crianças naturalmente têm uma maior aceitação ao novo companheiro ou cônjuge da mãe ou do pai. O vínculo, então, se estabelece com maior intensidade, até porque, o pai ou mãe afim participarão de toda a fase de crescimento e desenvolvimento do menor.

A criança, nesta hipótese, desde cedo, convive com o pai ou mãe afim, assim, a figura de autoridade por eles representada é inerente àquela família. Não absorveram os pequenos a autoridade exercida exclusivamente pelos pais biológicos, então, aprenderam a respeitar, as duas figuras, a do pai biológico e a do pai afim, cada qual representando o seu papel.

Contudo, quando o vínculo se estabelece na adolescência, quer seja por lealdade aos pais biológicos, quer seja por um sentimento de traição, o elo não se estabelece de pronto, devendo ser cultivado no dia a dia, para que, as relações afetivas se desenvolvam. Por conseguinte é naturalmente mais difícil para o outro cônjuge exercer autoridade sobre eles sem conflitos, mas, não se pode ignorar sua presença, pois situações cotidianas fazem com que o pai afim exerça subsidiariamente a função do pai biológico, como em caso de na madrugada ter que buscar o filho do outro cônjuge, ter que socorrer na escola em razão de um acidente, etc.

\footnotetext{
${ }^{238}$ GRISARD FILHO, Waldyr. Famílias reconstituídas. Novas uniões depois da separação. Ed. Revista dos
} Tribunais. São Paulo, 2007, pág. 130/131. 
Porém será esta qualidade do vínculo que determinará a união da criança e o adolescente com o grupo familiar em que vive.

Uma pesquisa realizada com adolescentes que vivem em famílias reconstituídas demonstrou que eles enfrentam maiores dificuldades de adaptação. Isto porque, o adolescente, ao mesmo tempo que necessita adaptar-se à nova família, deseja, por características de sua fase evolutiva, afastar-se da família para concretizar sua independência, investindo sua energia em outros interesses, como o social, o lazer, o profissional, priorizados nesta fase do desenvolvimento. ${ }^{239}$

Assim, os adolescentes acabam resistindo em aprender novos papéis na nova família, gerando, então dificuldades especiais para os pais afins em discipliná-los e com eles se relacionar. Estão os adolescentes vivenciando a natural fase de contestação das figuras de autoridade, como forma de descobrir sua própria identidade. Logo, a entrada na família de um novo integrante, potencializa os conflitos com relação as regras, aos valores e aos limites. Tal processo exigirá tempo de adaptação e reorganização.

Um estudo realizado com crianças e adolescentes, entre 10 e 17 anos, filhos de famílias originais e de famílias reconstituídas, utilizando-se do instrumento do desenho da família e posteriormente de respostas a uma ficha com dados biodemográficos que caracterizavam o núcleo familiar que viviam e, por fim com respostas ao Inventario sobre a Rede de Relações Interpessoais, constatou-se que: $39 \%$ das crianças que viviam em famílias reconstituídas desenharam a família com que moravam, 17\% ainda representaram a sua família original e $34 \%$ desenharam a família com quem habitava acrescida de alguns membros de sua família original. ${ }^{240}$

Ao analisar a proximidade e o afastamento dos membros da família, analisando-se o desenho, constatou-se que, comparando os dois grupos, das famílias originais e das famílias reconstituídas a proximidade da família em geral é semelhante nos dois grupos. Observou-se também, que quanto mais velho o adolescente, mais próximo era representado o casal na família reconstituída.

$\mathrm{O}$ estudo demonstrou também que a figura paterna era claramente valorizada nas famílias originais, enquanto, nas famílias reconstituídas o personagem valorizado aparece distribuído entre pai, mãe, padrasto e outros. Contudo, nas famílias

\footnotetext{
${ }^{239}$ CARTER, B \& MC GOLDRICK, M. As mudanças no Ciclo de Vida Familiar: Uma estrutura para a terapia familiar, Porto Alegre. Artes Médicas, 1995.

${ }^{240}$ WAGNER, Adriana e BANDEIRA, Denise R. O desenho da família. Um estudo sobre adolescentes de famílias originais e reconstituídas. Trabalho apresentado no VI Simpósio de Pesquisa e Intercambio Científico da ANPEPP, maio de 1996, parcialmente financiado pelo CNPQ e pela FAPERGS.
} 
reconstituídas, quando da análise dos personagens desvalorizados, estavam a madrasta $(33 \%)$ e o padrasto $(17 \%)$

Com este trabalho, concluíram as psicólogas Adriana Wagner e Denise R. Bandeira, que boa parte dos adolescentes já tem incorporada a nova estrutura familiar. Dizem que o processo de incorporação parece passar por diferentes etapas de maturação, que, num primeiro momento o jovem tem necessidade de manter sua família original intacta, sem a inclusão de novos membros, há resistência em aprender os novos papéis dentro da nova família, mas, num segundo momento, o menor passa pela etapa onde os papéis de pai ou mãe são substituídos pelos novos personagens da família reconstituída (pais e mães afins), sendo que, na última etapa ocorre a integração total de todos os personagens do novo contexto familiar.

Percebeu-se uma tendência dos adolescentes em reconhecer a formação do novo casal nas famílias reconstituídas, com, provável aceitação da separação dos pais.

Como visto, o conflito, ao menos em um primeiro momento existe e é quase inevitável, o processo é difícil e exige paciência mas, com o tempo e a convivência, passam as crianças e os adolescentes por um processo de aceitação e adaptação, que, ao final, integrará aquela família. Estabelece-se, quase sempre, um vínculo afetivo entre os integrantes da família reconstituída.

Para se aprender a respeitar e gostar é necessário tempo. A criança e o adolescente, com o tempo, deixam de olhar o cônjuge ou companheiro do pai de forma desconfiada e negativa, quase como responsáveis pelo término do relacionamento dos pais e, passam a descobrir os pais afins, como pessoas, permitindo uma maior proximidade. $\mathrm{E}$ não raro, maiores intimidades e estabelecimentos de verdadeiros vínculos de afeto. Aceitam e respeitam, então, as decisões dos pais.

Neste sentido, também a conclusão de Waldyr Grisard Filho, “originada de uma família monoparental, de longos anos, com filhos adolescentes, é difícil que o novo cônjuge ou companheiro da mãe exerça uma autoridade sem conflitos. Quer isto dizer que a idade é um fator relevante na aceitação do cônjuge ou companheiro do genitor. Será maior nas idades mais baixas, será menor nas idades mais altas, gerando grandes dificuldades para admitir um poder disciplinário do pai ou mãe afim. Também incide sobre o exercício da parentalidade a história precedente do pai ou mãe afim; se solteiro, 
divorciado ou viúvo sem filhos; sem nenhuma experiência parental anterior, atuam em um plano complementar e cooperativo, realizando distintos aspectos da função educativa." ${ }^{241}$

As crianças e os adolescentes, com o tempo, passam a se identificar como membros daquelas famílias e aceitar a autoridade do cônjuge ou companheiro de seu pai ou sua mãe. Os 'meio-irmãos' criam maior intimidade e passam a se enxergar como integrantes da mesma família.

Mas, para isto, é importante criar dentro do lar conjugal o ambiente de uma nova família e não simplesmente juntar duas famílias debaixo de um mesmo teto. É relevante, pois, que o casal defina rotinas e responsabilidades, partilhe tarefas, crie programas que envolva toda a família.

\subsection{ATUAÇÃO DOS PAIS AFINS QUANDO OS PAIS BIOLÓGICOS} NÃO SÃO ATIVOS

Situação distinta, porém, se observa diante da ausência dos pais biológicos, seja em razão de seu falecimento, seu desaparecimento, abandono ou pouco relacionamento com o filho. Nestas hipóteses, geralmente, ocorre a natural substituição, do pai afim para o exercício da função parental.

É nesta circunstância que os pais afins podem assumir integralmente a autoridade parental com relação aos filhos de seu companheiro ou cônjuge, uma vez que, as decisões poderão ser tomadas em conjunto pelo casal sem a interferência de pessoas estranhas à família. Exige-se menos esforço para uma conciliação.

Não são raros os casos em que os pais afins assumem integralmente a paternidade daquele menor, que, em razão da convivência e baseado na afetividade, firmou-se verdadeiro vínculo paterno-filial, decorrente da posse do estado de filiação.

Neste sentido, Ana Carolina Brochado Teixeira, diz: "não se pode ignorar que, principalmente quando um dos genitores biológicos é ausente, constitui-se, na maioria das vezes, uma parentalidade afetiva entre o filho afim e o genitor afim, embora ausente o elo biológico. Isso se faz possível em decorrência da posse de estado de filho, de pai e mãe, que pode ocorrer nas famílias reconstituídas. Esse fenômeno, que exige os requisitos do nome, do tratamento e da fama, deve ser cada vez mais valorizado, pois segue a tendência do Direito de valorar muito mais a essência das relações jurídicas do que a

${ }^{241}$ GRISARD FILHO, Waldyr. Famílias reconstituídas. Novas uniões depois da separação. Ed. Revista dos Tribunais. São Paulo, 2007, pág. 132. 
forma por elas assumidas. Nesse diapasão, vem crescendo, na ordem jurídica brasileira, a doutrina que admite a paternidade socioafetiva, atribuindo-se valor jurídico ao afeto. ${ }^{242}$

Nestas hipóteses, de assunção integral de responsabilidade pelo pai afim, quando ausente o pai biológico, verifica-se, que, configurado o estado de posse de filho e formado um vínculo afetivo intenso, está-se diante de verdadeira relação de socioafetividade. Nesta hipótese, o pai afim, tornou-se, efetivamente pai. Não é mais o caso de atuação subsidiária, mas, de atuação em substituição.

Registramos que, mesmo quando ausente o pai biológico, não são todos os pais afins que livremente assumem esta paternidade afetiva, preferem, por sua vez, atuar de forma subsidiária, sem grandes comprometimentos.

\subsection{A QUESTÃO ECONÔMICA COMO INFLUÊNCIA DA QUALIDADE DO VÍNCULO FAMILIAR}

Questão relevante para o exercício das funções parentais nas famílias reconstituídas, e, que pode determinar a qualidade do vínculo familiar é a econômica.

Diferentes são as atitudes dos pais afins que assumem integralmente a nova família daqueles que fazem diferença entre os participantes em razão da origem. Aqueles pais afins que não fazem diferença entre os filhos têm maior chance de integrar a família, posto que, para todos, os programas serão sempre os mesmos, quer nos finais de semana, nas viagens de férias, nas atividades extracurriculares, festas de aniversário e até mesmo no vestuário.

Pais afins que distinguem os seus filhos dos filhos de seu companheiro ou cônjuge tenderá a causar ainda mais conflitos em razão das diferenças dentro do ambiente familiar.

De igual forma, aquele que, sem possuir filhos, não se sente de forma alguma responsável pela ajuda na criação do filho de seu companheiro ou cônjuge, e não demonstra o necessário comprometimento para o estabelecimento de vínculos.

Revelam Cecília P.Grosman e Irene Martinez Alcorta que, em camadas socioeconômicas mais baixas, o nível de envolvimento do pai ou mãe afim é mais intenso e se amplia com a fragilidade da comunicação entre o genitor e os filhos. Por outro lado, tratando-se de pais afins de posição mais elevada, cultural e economicamente, o genitor

242 TEIXEIRA, Ana Carolina Brochado. Família, guarda e autoridade parental. Ed. Renovar. Rio de Janeiro, 2005, pág. 121. 
não guardião preserva em maior medida sua função educativa e o novo casal só funciona como casal parental plenamente em relação a seus próprios filhos. Nestas famílias, muitas vezes, os filhos de um e de outro não convivem sob o mesmo teto, as saídas de férias são organizadas de maneiras diferentes, como se fossem territórios separados. Os laços familiares, para evitar desencontros, são separados, criando diversos núcleos familiares e não funcionam como uma unidade. ${ }^{243}$

Quando o laço não é intensificado formam-se vários grupos familiares que não funcionam como unidade, como de cada cônjuge em relação aos seus próprios filhos, reduzindo, por conseguinte, o exercício das funções parentais, mas que, ainda assim, subsistem.

Por fim, cumpre destacar a diferença entre 'afinidade' e 'socioafetividade', ou seja, até aonde sou 'pai' e até aonde sou 'padrasto'.

Como visto até então, a paternidade socioafetiva é exercida por aquela pessoa que, livremente, assumiu integralmente a função parental. $\mathrm{O}$ pai afetivo exerce a função parental em substituição ao pai biológico que, por alguma razão - morte, abandono, etc - não está presente na vida de seu filho. A assunção desta responsabilidade é consciente e se dá quando presente a posse de estado de filho e estabelecido forte vínculo afetivo.

Diferente é o exercício complementar da parentalidade pelos pais afins. Nesta hipótese, o pai biológico pode ou não estar presente, e a intensidade do exercício da autoridade varia de acordo com o seu comprometimento, a origem da família e a idade dos filhos.

O fato é que o cotidiano e a convivência fazem gerar inúmeras situações envolvendo a família, sendo impraticável para o cônjuge se manter completamente alheio às decisões relativas aos filhos de seu companheiro.

Há, de uma forma ou de outra, conforme o arranjo encontrado por aquela família, o exercício da autoridade parental de forma subsidiária, complementar. Este exercício decorre, não só da convivência mas também, por obrigações morais e naturais e, especialmente, do vínculo de afeto formado entre os integrantes da família.

O que se pretende dizer é que, nestes casos, o poder familiar é, de fato, exercido pelo pai original, pela mãe original e também pelo novo companheiro ou novo cônjuge em família reconstituída. Isso é decorrência da natureza dinâmica das relações sociais, funcionais e afetivas nas entidades familiares e que, apesar da determinação do

${ }^{243}$ GROSMAN, Cecilia P., ALCORTA, Irene. Famílias Ensambladas, Buenos Aires, Universidad, 2000, p. $169 / 170$. 
artigo 1.636 do CCB 2002 em sentido contrário, as situações cotidianas mostram uma outra realidade.

\section{CRÍTICA AO ARTIGO 1.636 DO CÓDIGO CIVIL DE 2002}

Não é possível ignorar as responsabilidades dos pais afins, pois estes terão influência na socialização dos filhos de seu cônjuge ou companheiro, transmitirão valores, princípios, modelos de conduta, por tal razão, é extremamente necessário que a lei confira aos pais afins certa autoridade, proveniente da convivência e da responsabilidade de todo adulto sobre menor a seu encargo.

Claro está que a legislação não está preparada para tratar corretamente a questão das famílias reconstituídas, onde pais, mães e pais afins têm funções específicas e relevantes no dia a dia da família.

A psicanálise e a sociologia orientam no sentido de que tem a família funções que lhe são próprias, e que escapam à abrangência do Direito; funções que lhe são anteriores na medida em que o Direito aparece em geral para ajustar situações não protegidas pelo Estado e que são relevantes à paz social ou à efetividade do conceito do justo como ideal.

Rodrigo da Cunha Pereira, sob a ótica da Psicanálise, esclarece quanto à importância da figura do pai e da mãe dentro do lar: "Jacques Lacan, desenvolvendo sua teoria, demonstra que o inconsciente é estruturado como linguagem e que a lei é representada pela figura do pai. Não necessariamente o pai biológico, mas "um" pai, ou uma metáfora paterna. Como se disse, todo esse discurso que engendra teorias, explica fatos e conta a história, assenta-se na figura do homem. Mesmo o Complexo de Édipo, traduzido por Freud em suas teorias, em que a mulher, mãe e figura central, serviu para remeter à responsabilidade da primeira lei ao pai." $" 244$

Sob a mesma ótica, ensina Giselle Câmara Groeninga, explica: "a família mudou e, de uma família com uma rígida divisão de papéis passamos para uma família com possibilidades e funções exercidas atualmente por homens e mulheres, não sem certo prejuízo das certezas antigas que tínhamos. (...) É preciso que se diga que as funções materna e paterna, existem na nossa subjetividade. Às vezes, elas existem na realidade, exercidas por pai e mãe, outras vezes não, mas sempre há esse terceiro, mesmo que virtual

${ }^{244}$ PEREIRA, Rodrigo da Cunha. Direito de Família: uma abordagem psicanalítica. Belo Horizonte, Del Rey, 1997, pág. 94. 
no nosso imaginário. O que não podemos é mistificar esse ideal, transformando-o em única possibilidade existente de família. E é isso que caiu por terra como o reconhecimento das famílias monoparentais, por exemplo (...) Como eu disse, o nosso imaginário é composto desta família: pai, mãe e filho. Precisamos psiquicamente dessas diferenças entre um e outro. E tanto mais fácil fica a formação do nosso psiquismo e da nossa personalidade quanto maior a oportunidade de convivência com um e com outro, para que ocorra a necessária oscilação afetiva (...),245

Do que se extrai a importância das funções dos pais afins dentro da família reconstituída. E, somente com a transmissão dos valores pelos pais, sejam biológicos ou afetivos, dentro do ambiente familiar a formação do indivíduo será plena.

Relevante a figura da delegação, ou pelo menos da faculdade de que um pai ou mãe afim no exercício da autoridade parental possa transferi-la ao seu cônjuge ou companheiro, de maneira provisória, em determinadas situações. Entre os pais naturais, estes acordos são implícitos e funcionam naturalmente no âmbito social. Esta permissão apenas beneficiaria os filhos, que possuem uma relação afetiva com os pais afins, como também aos pais que poderão exercer sua autoridade de forma comprometida e responsável.

É necessário, pois, a legitimação dos papéis exercidos por pais e mães afins dentro da família reconstituída, pelo ordenamento jurídico, que, então, poderá orientar a conduta dos membros desta estrutura, em consonância com seus costumes e sua cultura.

Todavia, diz o artigo 1.636 do Código Civil: "o pai ou a mãe que contrai novas núpcias, ou estabelece união estável, não perde, quanto aos filhos do relacionamento anterior, os direitos ao poder familiar, exercendo-os sem qualquer interferência do novo cônjuge ou companheiro".

A parte final de tal dispositivo denota a total ausência do princípio do melhor interesse da criança, indo de encontro à tendência mundial de privilegiá-lo, conforme já orientava o Estatuto da Criança e do Adolescente.

O Estatuto da Criança e do Adolescente nos orienta que a família assume espaço importante para a realização dos direitos fundamentais infantojuvenis, logo a

${ }^{245}$ GROENINGA. Giselle Câmara. Afetos, sexualidade e violência - A família desmistificada. In. DIAS, Maria Berenice e BASTOS, Eliene Ferreira. Família além dos mitos. Ed. Del Rey, Belo Horizonte, 2008, pág. 74. 
reestruturação da primazia da pessoa humana nas relações civis é a condição primeira da adequação do direito à realidade social e aos fundamentos constitucionais.

Nesta hipótese, estariam a Constituição Federal de 1988 e o ECA desprestigiados e ignorados pelo Direito Civil, pois é fundamental que o novo cônjuge ou companheiro participe do poder familiar tendo em vista exatamente o princípio do melhor interesse da criança e do adolescente.

Se assim não fosse, imagine-se como seria a realidade em uma família reconstituída composta por mãe e seus filhos de relacionamento anterior, pai e seus filhos trazidos também de relacionamento anterior e ainda mais filho comum. De que modo seria exercido o poder familiar nas questões operacionais? Como seria evitada a discriminação deste ou daquele menor? Como seriam as questões relativas à cultura, à educação, à orientação, aos bons exemplos? Como seria educar? Que padrão seria seguido? Que funções teria o pai afim?

Dúvidas não restam que o Código Civil precisa ser atualizado quanto a estas questões, especialmente no tocante à orientação do artigo 1.636, que contraria princípios constitucionais e conflita com disposições legais do próprio Código Civil. Lembramos que o próprio legislador sempre teve preocupações relativas ao estabelecimento e manutenção do parentesco por afinidade, tratados nos artigos 1.593 e 1.595 do Código Civil.

Este, também, o entendimento de Ana Carolina Brochado Teixeira: “O art. 1.636 do $\mathrm{CCB} / 02$, é taxativo no sentido de que as novas núpcias ou nova união estável contraídas pelo genitor não induzem à perda do poder familiar quanto aos filhos do relacionamento anterior. A situação se torna mais complexa em função da última parte do 'caput' daquele dispositivo, que estabelece que o exercício da autoridade parental se perfaz sem a interferência do novo cônjuge ou companheiro. O mesmo ocorre quando o genitor solteiro casar ou estabelecer união estável. Entretanto, a prática reflete exatamente o oposto. A realidade impõe novas formas de arranjos familiares, que provocam rearranjos internos, decorrentes da estrutura havida na família anterior, agora desfeita. Cada cônjuge ou companheiro, além dos filhos, leva a sua experiência para aquele novo relacionamento. É preciso muita flexibilidade e diálogo para que se alcance harmonia no funcionamento da nova família. Para tanto, é inevitável que algumas funções, sejam maternas ou paternas, sejam cumpridas pelo pai ou pela mãe afim."246

246 TEIXEIRA, Ana Carolina Brochado. Família, guarda e autoridade parental. Ed. Renovar. Rio de Janeiro, 2005, pág. 125. 
Ainda que não se possa regulamentar todas questões atinentes à família reconstituída e tampouco pautar comportamentos através do ordenamento, a lei pode conferir um marco de legitimidade no exercício das funções parentais nas novas famílias, permitindo o exercício interdependente e complementar entre os pais biológicos e os afins dentro de limites precisos.

Neste momento, oportuna a lição trazida por Rodrigo da Cunha Pereira, ao demonstrar que as normas criadas pela sociedade devem apenas refletir as necessidades daquela sociedade: "O jusfilósofo alemão Hans Kelsen, em sua obra Teoria Geral das Normas, desenvolve seu raciocínio de que há uma norma fundante que rege e coordena as normas jurídicas (aliás, muito bem fundamentado na sua divisão de sentido objetivo e subjetivo da norma). Exemplifica a norma fundamental da moral cristã como fundante das normas gerais cristãs. É um raciocínio não só brilhante, mas instigante. Ele nos impele a perguntarmo-nos o que é a lei fundamental. Kelsen é definitivo quando diz que as normas não são criadas pela ciência jurídica, mas tão somente descritas por ela." 247

Acredita-se que a relevância do assunto está exatamente na relação de poder familiar, na relação de afeto e no dever que tem o novo cônjuge ou companheiro de interferir sim para que os filhos sob factual guarda do casal reconstituído, sem excluir eventual guarda e as responsabilidades do pai ou da mãe ausentes do convívio operacional, sejam pessoas seguras de si, bem informadas, saudáveis e felizes e tenham um bom ambiente familiar.

$\mathrm{Na}$ doutrina brasileira, no exercício da responsabilidade parental, a posição não é pacífica. Para alguns doutrinadores, os pais e mães afins podem opinar em todas as questões relativas aos filhos e filhas afins, todavia, a decisão deverá ser compartilhada. Para outros, é aceitável a opinião, mas a decisão não pode usurpar a parentalidade do pai ou da mãe biológicos.

No direito internacional, em alguns países como a Alemanha e França permite-se que o pai afim compartilhe responsabilidade parental com o pai biológico, estando este autorizado a tomar atitudes e decisões na vida de seu filho afim sem privar o pai biológico de seus direitos.

O direito brasileiro não outorga ao pai ou mãe afim maior reconhecimento mediante a afirmação de certos direitos e responsabilidades, que atuem como orientadores de conduta com o objetivo de minimizar os conflitos e facilitar a

${ }^{247}$ PEREIRA, Rodrigo da Cunha. Direito de Família: uma abordagem psicanalítica. Belo Horizonte, Del Rey, 1997, pág. 32. 
estabilidade do sistema familiar reconstituído. É importante que a lei reconheça a realidade de uma convivência, que gera relações cotidianas, fonte de direitos e responsabilidades em relação à socialização, assistência material e emocional, à educação dos filhos que vivem nessas famílias.

A lei deve orientar as expectativas dos integrantes dessas famílias, mediante normas que constituam referências institucionais, transformando a figura dos pais afins, silenciadas pela própria lei, em figuras positivamente integrantes da família, sem oposições ou omissões. O Estado deve proteger a família afetiva e estimular compromissos e responsabilidades.

Quanto a importância de regulamentação pelo ordenamento jurídico das famílias reconstituídas, assim, justifica Waldyr Grisard Filho: "as concordâncias interpessoais podem deixar desguarnecidos os direitos de seus membros, principalmente das crianças e dos adolescentes, que não podem defender por si só seus interesses pessoais. Então, estas famílias reclamam do corpo social uma atitude mais comprometida, que estimule e valorize comportamentos responsáveis de seus integrantes adultos, criando o lugar e espaço próprios ao pai ou mãe afim no âmbito familiar. Neste sentido, a lei não pode permanecer alheia, fixando certas regras mínimas que afirmem o compromisso e as obrigações dos que vivem em companhia de menores e assumem cotidianamente seus cuidados, sejam ou não seus pais biológicos. A finalidade da lei seria fixar pautas claras de funcionamento, onde, porém, o espaço do 'não direito' e o poder da autonomia da vontade devem ser mais amplos, em razão da variedade existencial. A demanda social exige, à estabilidade de seu conjunto, a criação de referências institucionais, que ordenem os direitos e deveres de pais e mães afins com filhos afins durante a união e depois de sua ruptura." 248

A estrutura complexa das famílias reconstituídas requer um modelo distinto de funcionamento. De rigor, pois, a criação de um espaço próprio aos pais e mães afins pelo ordenamento jurídico. Neste passo, o direito deverá reconhecer a existência dos pais e mães afins, no âmbito das famílias reconstituídas, regulamentando-a apropriadamente, visando à afirmação da posição dos integrantes das famílias reconstituídas, dando-lhes legitimidade para colaborar no cuidado do filho afim.

No mesmo sentido, a posição de Ana Carolina Brochado Teixeira: "Não obstante a grande relevância do fenômeno na esfera sociológica é incipiente a manifestação ${ }^{248}$ GRISARD FILHO, Waldyr. Famílias reconstituídas. Novas uniões depois da separação. Ed. Revista dos
Tribunais. São Paulo, 2007, pág. 101. 
jurídica sobre o tema, não apenas em termos legislativos, mas também, doutrinários e jurisprudenciais. O único pronunciamento legal cinge-se ao art. 1.595 do CCB/02, que prevê o parentesco por afinidade do cônjuge ou do companheiro aos parentes do outro, que se restringe aos ascendentes, descendentes e irmãos. Entretanto, a lei se cala a respeito das relações jurídicas que se formam entre esses novos parentes afins. (...) E, então, conclui a autora "como uma nova forma de família, merece proteção do Estado, além de respeito da sociedade, principalmente em face das relações afetivas sólidas que podem se formar em seu bojo. Por isso, é uma realidade que não mais pode ser ignorada". 249

Contudo, para Maria Cláudia Crespo Brauner, "não nos parece haver a necessidade de se criarem dispositivos protegendo a família reconstituída, que venham a definir o papel da mãe ou do pai social ou afetivo, ou que prevejam a possibilidade de exercício da guarda, visita, participação na educação e na prestação de alimentos, ao contrário, seria importante destinar esforços para se constituírem soluções doutrinárias e jurisprudenciais que assegurem o interesse superior da criança a viver em um ambiente equilibrado e acolhedor" 250

Mas, acima de tudo, ao contrário da orientação do artigo 1.636 que ignora e veda o exercício da parentalidade pelos pais afins, é primordial que se reconheça o seu lugar dentro da família reconstituída e a importância de sua função subsidiária, enquanto executores de uma parentalidade integrativa à dos pais biológicos, legitimandose, pois, suas condutas. Pois, só assim, estará se cumprindo o preceito constitucional do melhor interesse do menor.

Todavia, enquanto não reconhecida a legitimidade para o desempenho da função de parentalidade pelos pais afins, importante, que os operadores do direito se orientem pelos mandamentos constitucionais, como normas de eficácia imediata, para a realização dos princípios do melhor interesse do menor, tendo em vista o seu pleno desenvolvimento, integrado no seio de sua família.

É certo, que doutrina e jurisprudência têm reconhecido o caráter normativo de princípios como o da solidariedade social, da dignidade da pessoa humana, entre outros, aos quais se tem assegurado eficácia imediata nas relações de direito civil. Somente, assim, através de recursos interpretativos, serão preservados os valores constitucionais e os princípios fundamentais da pessoa humana.

${ }^{249}$ TEIXEIRA, Ana Carolina Brochado. Família, guarda e autoridade parental. Ed. Renovar. Rio de Janeiro, 2005, pág. 119.

${ }^{250}$ BRAUNER, Maria Cláudia Crespo. Reinventando o direito de família: novos espaços de conjugalidade e parentalidade. Revista Trimestral de Direito Civil, v. 18, p. 79-107. 
Neste sentido, Luiz Edson Fachin, ensina que "a doutrina fornece bússolas, pois há que se ler atentamente o Código Civil de 2002 na perspectiva civilconstitucional, para se atribuir não só às cláusulas gerais, aqui realçadas, mas a todo o corpo codificado um significado coerente com a tábua de valores do ordenamento, que pretende transformar efetivamente a realidade a partir das relações jurídicas privadas, segundo os ditames da solidariedade e justiça social.",251

Na mesma linha, Gustavo Tepedino leciona que “torna-se indispensável que o legislador de hoje recorra à técnica narrativa, de algum modo à retórica e aos sentimentos (não subjetivos dele, legislador, mas da sociedade, recolhendo democraticamente os valores predominantes na realidade social), para que determine o conteúdo axiológico das cláusulas gerais e dos conceitos jurídicos indeterminados. Parece indiscutível a necessidade de se desenvolver, por parte do legislador e do intérprete, a técnicas das cláusulas gerais, cuja adoção evita as profundas lacunas causadas pela evolução da sociedade; sendo impossível ao legislador acompanhar o passo dos acontecimentos, e infrutífera a tentativa de tipificar a totalidade das situações jurídicas que, assim como os bens jurídicos objeto do direito, multiplicam-se a cada momento." ${ }^{, 252}$

Não obstante, mais uma vez, registramos a imprescindibilidade de alteração do artigo 1.636 do Código Civil brasileiro de 2002, a fim de que sejam legitimados os lugares dos pais e mães afins dentro das famílias reconstituídas, como forma de chancelar a sua função parental complementar à dos pais biológicos, o que, servirá como orientação de conduta, com o objetivo de minimizar os conflitos e facilitar a estabilidade do sistema familiar reconstituído.

E neste sentido a louvável proposta do Estatuto das Famílias, que tramita perante o Congresso Nacional, Projeto de Lei n 674 de 2007, feito pelo Deputado Sérgio Barradas Carneiro, elaborado em conjunto com uma comissão científica do IBDFAM Instituto Brasileiro de Direito de Família, especialmente, em seus artigos 60, 88 e $91^{253}$.

\footnotetext{
${ }^{251}$ FACHIN, Luiz Edson. Comentários ao Novo Código Civil. Do Direito de Família. Do direito pessoal. Das Relações de Parentesco. Arts. 1.591 a 1.638. Vol. XVIII - Coord. Sávio de Figueiredo Feitosa $-1^{\mathrm{a}}$ edição. Rio de Janeiro: Forense, 2003, pág. 261.

${ }^{252}$ TEPEDINO Gustavo (Coord). in Problemas de direito civil-constitucional (O Código Civil, os chamados microssistemas e a Constituição: premissas para um reforma legislativa), Rio de Janeiro: Renovar, 2000, pág. 10.

${ }^{253}$ Estatuto das Famílias. Projeto de Lei 674/2007.

Artigo 60. O divórcio e a separação não modificam os direitos e deveres dos pais em relação aos filhos. Artigo 88. A dissolução da entidade familiar não altera as relações entre pais e filhos.

Artigo 91. Constituindo os pais nova entidade familiar, os direitos e deveres decorrentes da autoridade parental são exercidos com a colaboração do novo cônjuge ou convivente ou parceiro. Parágrafo único. Cada
} 
Da leitura dos dispositivos possível notar que a proposta do Estatuto das Famílias, adequadamente, manteve a dissociação entre autoridade parental e convivência dos pais. Mas, especialmente, de forma expressa, possibilita o exercício da autoridade parental de forma complementar, no caso de novas uniões, pelos novos cônjuges ou companheiros dos pais.

A proposta, de maneira acertada, não só extirpou a impossibilidade de interferência dos novos cônjuges ou companheiros dos pais no exercício da autoridade parental, como, expressamente, possibilitou tal exercício em colaboração e legitimou a conduta dos pais afins, como para a representação dos menores em determinadas situações, como até então defendido neste trabalho. 


\section{VIII - LEGISLAÇÃO ESTRANGEIRA.}

O presente capítulo tem como objetivo o estudo da legislação estrangeira quanto ao exercício da autoridade parental em diferentes países, especialmente, quanto à posição dos novos cônjuges ou companheiros em relação aos filhos do outro nas famílias reconstituídas.

Buscar-se-á, verificar se a legislação alienígena legitima a conduta dos pais afins, ou, ainda, se confere alguma responsabilidade ou direito a estes participantes da família reconstituída..

O estudo será realizado pela análise da Carta Constitucional e do Código Civil dos diferentes países e será apresentado de forma dividida por país para melhor compreensão.

\section{ALEMANHA}

A legislação alemã será estudada através da tradução da Carta Constitucional e do Código Civil Alemão para a língua espanhola. ${ }^{254}$

A família é tratada na Constituição Alemã de forma ampla e genérica no artigo $6^{\circ}$, que tutela o matrimônio e a família, em um único dispositivo. Estabelece o artigo 6: “(1) O matrimônio e a família se encontram sob proteção especial do Estado; (2) O cuidado e a educação dos filhos é um direito natural dos pais e dever incumbido prioritariamente a eles; (3) Os filhos só poderão ser separados da família, contra a vontade dos responsáveis, em virtude de lei, quando estes falharem no cumprimento do seu dever ou quando, por outros motivos, os filhos corram perigo de ficar abandonados; (4) Toda mãe tem direito de proteção e assistência pela comunidade; (5) A lei deverá assegurar aos filhos extramatrimoniais as mesmas condições que a dos filhos nascidos dentro do

\footnotetext{
${ }^{254}$ A Constituição Alemã traduzida para a língua espanhola pode ser encontrada no site da Embaixada Alemã no http://www.brasilia.diplo.de/Vertretung/brasilia/pt/01 Deutschland/Constituicao/grundgesetz_seite.html, acesso em 15/11/2009. O Código Civil Alemão foi traduzido para a língua espanhola por Emílio Eiranovas Encinas, na obra: EIRANOVAS ENCINAS, Emilio; COESTER-WALTJEN, Dagmar. Código civil alemán comentado: BGB, Madrid: Marcial Pons, Ediciones Juridicas y Sociales, 1998.
} 
matrimônio no que diz respeito a seu desenvolvimento físico e espiritual e à sua posição social". 255

A Constituição Alemã, como visto, tutela a família de forma aberta e ampla, o que permite, a proteção do modelo plural de agrupamento familiar, tornando possível o reconhecimento das famílias reconstituídas.

O Código Civil Alemão, por sua vez, trata do Direito de Família em seu livro quarto, interessando-nos, particularmente, a segunda seção que trata do parentesco nos artigos 1.589 e seguintes.

O Código Civil define no artigo 1.589 o parentesco, como relação entre pessoas que descendam umas das outras em linha reta ou que descendam de uma mesma terceira pessoa, como parentes na linha colateral. ${ }^{256}$

Reconhece, também, o direito alemão o parentesco por afinidade, em seu artigo 1.590, como a relação estabelecida entre o cônjuge e os parentes do outro. Tal parentesco não se extingue com a dissolução do matrimônio. ${ }^{257}$

Com relação aos filhos, estabelece o Código Civil Alemão que os pais têm obrigação e direito de cuidados pessoais e patrimoniais. O cuidado pessoal compreende a educação, formação, guarda e residência dos filhos (artigo 1.631). Para tanto, devem os pais observar a capacidade e a necessidade de independência dos filhos menores para o seu desenvolvimento (artigo 1.626) ${ }^{258}$. Destacamos que, na parte final deste dispositivo, ressalta o legislador alemão a promoção da relação dos filhos menores

\footnotetext{
${ }^{255}$ Artícolo 6. (Matromio y família). (1) El matrimonio y la família se encuentran bajo la protección especial del orden estatal. (2) El cuidado y la educación de los hijos son el derecho natural de los padres y El deber que lês incumbe prioritariamente a ellos. La comunidad estatal velará por su cumplimiento. (3) Em contra de la voluntad de las personas autorizadas para su educación, los hijos sólo podrán ser separados de sus famílias em virtud de uma ley, cuando las personas autorizadas para su educación no cumplan com su deber o cuando, por otros motivos, los hijos corran peligro de quedar abandonados. (4) Toda madre tiene derecho a la protección y la asistencia por parte de la comunidad. (5)La legislación deberá asegurar a los hijos extramatrimoniales las mismas condiciones que para los hijos nacidos dentro del matrimonio em lo que respecta a su desarrollo físico y espiritual y a su posición social.

${ }^{256}$ Artícolo 1589 (Parentesco). Personas que desciendam unas de otras son parientes em linea recta. Persinas que no Sean parientes em línea recta que desciendan de uma misma tercera persona serán parentes em línea colateral. El grado de parentesco se determina según El número de nascimientos intervinientes.

${ }^{257}$ Artícolo 1590 (Parentesco por afinidad). 1. Los parientes de um cónyuge son parientes políticos del outro cónyuge. La línea y el grado del parentesco por afinidad se determina según la línea y el grado del parentesco interveniente. 2. El parentesco por afinidad seguirá vigente incluso trás la disolución del matrimonio al que debe su existência.

${ }^{258}$ Articolo 1626. (Cuidado paterno) consideración de la creciente independência del hijo). 1. Los padres tienem la obligación y el derecho de cuidar del hijo mwnor de edad (cuidado paterno). Dicho cuidado comprende El cuidado de la persona del hijo (cuidado personal) y el de su patrimônio (administración patrimonial). 2. Los padres observarán en el ejercício del cuidado la creciente capacidad y necesidad de independência del hijo em cuanto a su actuación consiente y resonsable. Debatirán com el hijo las cuestiones relativas a su cuidado y promeoverán la adopción de acuerdos. 3. Para el bien del hijo se promoverá normalmente su relación com ambos padres. Lo mismo será válido respecto de su relación com otras personas que condicionem su desarollo.
} 
não só com ambos os pais, mas também com as pessoas que estejam envolvidas no seu desenvolvimento, como por exemplo, os pais afins.

Nos casos em que os pais não sejam casados, estabelece o código que a custódia será de ambos os pais, algo semelhante à guarda compartilhada, quando houver acordo, sendo que, nos demais casos a guarda será atribuída à mãe (artigo 1626a) ${ }^{259}$.

Com a separação dos pais, a custódia conjunta não é afastada imediatamente. Contudo, podem os pais solicitar ao Tribunal que lhe ceda a custódia, ou mesmo uma parte dela, de forma única, que, será concedida caso o outro pai consinta e o filho, se maior de 14 anos não se oponha à decisão, ou, caso o juiz entenda que a atribuição da guarda única será o melhor para o menor. Do contrário, permanece a guarda conjunta $(\operatorname{artigo} 1.672)^{260}$.

Seguindo o princípio do bem-estar do filho menor, quando a guarda for exercida unilateralmente pela mãe, o pai poderá, com o consentimento desta, solicitar a custódia ou parte dela, que será decidida pelo Tribunal (artigo 1672) ${ }^{261}$.

Interessante destacar que o Código Civil Alemão, não obstante estabeleça ser dos pais, primeiramente, a obrigação de cuidados e educação dos filhos, permite a intervenção de terceiros que partilhem do seu desenvolvimento, entre os quais, podem ser considerados os pais afins. O artigo 1.634, em seu parágrafo segundo, expressamente prevê a possibilidade do Tribunal regular as condições e a forma de exercício do poder parental, inclusive, com relação a terceiros. ${ }^{262}$

\footnotetext{
${ }^{259}$ Artícolo 1626a. (Cuidado paterno de padres no casados). 1. Em caso de que los padres no estén casados em el momento del nascimiento del hijo el cuidado de este les corresponderá em común cuando: $1^{\circ}$ ellos así lo declaren (declaración sobre el cuidado del hijo) $2^{\circ}$ contraigan matrimonio entre si; ello será también de aplicación em caso de que dicho matrimonio sea posteriormente declarado nulo. 2. En los demás casos, el cuidado coreesponderá a la madre.

${ }^{260}$ Articolo 1671 (Separación em caso de cuidado paterno común). 1. Em caso de que los padres que ejerzan conjuntamente el cuidado paterno viveran separados de forma definitiva, cada uno de ellos podrá solicitar que el Tribunal familiar Le ceda el cuidado paterno o uma parte del mismo a título unilateral. 2. Deberá estimar-se la solicitud, siempre que: $1^{\circ}$ el outro padre lo consienta, salvo que el hijo haya cumplido los catorce años y se oponga a dicha cesión, o $2^{\circ}$ sea de esperar que la exctensión del cuidado común y su cesi[on al peticionário se alo mejor para el bien estar del hijo. 3. No deberá estimarse la solicitud cuando el cuidado paterno deba regularse de forma distinta conforme a otros preceptos.

${ }^{261} 1672$ (Separación em caso de cuidado paterno ejercido por la madre). 1. Em caso de que los padres vivam definitivamente separados y que el cuidado paterno corresponda a la madre conforme al $\S 1626^{\mathrm{a}}$, apartado 2 , el padre podrá, con el consentimiento de ésta, solicitar que el Tribunal familiar Le ceda dicho cuidado o parte de El. Deberá estimarse la solicitud cuando la cesión sea favorable al bienestar del hijo. 2. En la medida em que haya sido estimada dicha solicitiud según el apartado 1, el Tribunal familiar podrá decidir, a petición de uno de los padres y com el consentimiento del outro, que el cuidado paterno corresponde a los dos conjuntamente, siempre que ello no prejudique el bienestar del hijo. Ello será, asimismo de aplicación em caso que la cesión descrita em el apartado 1 fuese de nuevo revocada.

${ }^{262}$ Artícolo 1634 (Derecho al trato personal com el hijo; información). 2. El Tribunal familiar podrá regular más concretamente las condiciones del trato com el hijo y de su ejercício, incluso com respecto de terceros. Mientras no exista determiniación de su parte el derecho será ejercido por el padre a quien no corresponda el
} 
Da mesma forma, estabelece expressamente o parágrafo terceiro do artigo 1.684, que, o direito de terceiros com relação aos menores poderá ser regulamentado pelo Tribunal, de forma detalhada, inclusive quanto à sua extensão. ${ }^{263}$

Destacamos, especialmente, o artigo 1685 do Código Civil Alemão, que, de forma expressa reconhece o direito dos pais afins em relação aos menores, quando tenham convivido dentro do ambiente familiar, caso este contato seja em benefício da criança e do adolescente ${ }^{264}$.

Nesta linha, permite também a legislação alemã a adoção do novo nome de família à criança em razão do novo matrimônio de um de seus pais, a atribuição de um pequeno pátrio poder aos pais afins e, ainda, o direito de visitas.

Pela regra contida no artigo 1.618, o cônjuge do pai ou da mãe que conviva com a criança e não seja seu pai poderá conceder seu nome de casado ao filho mediante declaração ao Registro Civil, solicitando alteração de nome. O nome poderá anteposto ou adicionado ao nome anterior do menor. A adição ao nome requer o consentimento do pai, se a criança tiver seu nome e, se a criança tiver seis anos, o seu consentimento. O consentimento do outro pai poderá ser suprido pelo Tribunal, quando a adição do nome for para o bem do menor. ${ }^{265}$

A possibilidade de alteração do nome de nascimento da criança demonstra grande avanço do sistema alemão na concretização das famílias afetivas. Com base no melhor interesse do menor, viabilizou-se a plena integração familiar no âmbito dos lares reconstituídos, por exemplo.

cuidado personal del hijo, según el §1632, apartado 2. El Tribunal familiar podrá limitar o excluir el derecho cuando ello resulte necesario para el bienestar del hijo.

${ }^{263}$ Articolo 1684 (Derecho de trato del hijo y de los padres). 3. El Tribunal familiar podrá regular mas detalladamente, incluso frente a terceros, el alcance del derecho al trato com el hijo, lo que puede convellar el cumplimiento por las partes del deber dispuesto em el apartado 2 .

${ }^{264}$ Artícolo 1685 (Derecho de trato de otras personas). 1. Los abuelos y hermanos tienen el derecho a tratar com el hijo si ello resultara beneficioso para su bienestar. 2. Lo mismo se aplicará para los cónyuges de uno de los padres que hayan convivido em comunidad doméstica durante cierto tiempo com el hijo, y para las personas bajo cuyo cuidado familiar este hubiere permanecido durante cierto tiempo. 3. El §1684, apartado 2 a 4 , se aplicará por analogia.

${ }^{265}$ Artícolo 1618. (Denominación). El padre que tenga a su cargo el cuidado del hijo soltero y el cónyuje de aquél que no sea padre del hijo, podrán conceder a éste su nombre de casados, mediante declaración ante el encargado de Registro civil. Dicho nombre podrá asimismo preceder o ser anãdido al apellido anterior del hijo; um nombre de casados anteriormente añadido o prevalente desaparecerá. Em caso de que el hijo tenga el apellido del outro padre, la concesión, preferência o añadido requerirán el consentimiento de este, y em caso de Haber cumplido el hijo seis años, también el consientimento de este último. El Tribunal familiar podrá suplir el consentimiento del outro padre cuando la concesión, prevalência o añadido del apellido resulte necesario para el bien del hijo. Las declaraciones deberán realizarse em forma fehaciente. El §1617c se aplicará por analogia. 
Neste contexto, também concedeu a legislação alemã a figura denominada pela doutrina de pequeno pátrio poder aos pais afins, por eles ainda denominados padrastos e madrastas, no artigo $1.687 \mathrm{a}$ e $1.687 \mathrm{~b} .{ }^{266}$ É atribuído ao cônjuge de um dos pais que tem a guarda, e não é o pai da criança, o direito de codecisão nos assuntos diários da criança, o qual deve ser exercido com o consentimento do pai que tem a guarda parental. Nos casos urgentes, o cônjuge tem o direito de agir como for necessário para o bem da criança, mas deve informar imediatamente o pai que tem a guarda parental. Tais direitos podem ser limitados ou excluídos quando for necessário para o bem da criança.

Com a atribuição do 'pequeno pátrio poder' o sistema alemão legitimou a conduta dos pais afins, especialmente no trato diário com as crianças, indispensável, para o bom funcionamento das famílias reconstituídas, como até então exposto no presente estudo. Tal conquista merece destaque e aplausos como forma de tutela deste novo modelo familiar.

O direito alemão, assegurou também, aos pais e filhos afins, o direito de visita, no caso de separação dos cônjuges, quando a convivência for benéfica para o desenvolvimento da criança, de acordo com o já mencionado artigo 1.685. Importante a manutenção do convívio entre pais e filhos afins, evitando o rompimento de relações consolidadas no tempo, com pessoas que serviram de referência e lhe ajudaram no seu desenvolvimento.

\section{PORTUGAL}

A legislação portuguesa será estudada por meio das normas contidas na Constituição da República e do Código Civil ${ }^{267}$.

\footnotetext{
${ }^{266}$ Articolo 1687b. (Derecho de decisión del padre que conviva com el hijo sin disponer de su cuidado) Em caso del padre que no disponga del cuidado paterno y com quien resida el hijo com el consentimiento del outro padre o de outro titular del cuidado paterno o por decisión judicial serán de aplicación por analogia el $\S 1687$, apartado 1 , frases $4^{\mathrm{a}}$ y $5^{\mathrm{a}}$, y apartado 2 . 1687b (Derecho de cuidados del conyuge). 1. El conyuge del padre que disponga del cuidado paterno e que no sea uno de los padres del hijo, tiene derechos al trato com el hijo conjuntamente com el padre e deberá ejerce-lo com su consientimiento. 2. En caso de urgencia el conyuge puede actuar como necesario para al bien del hijo, contudo deberá informar imediatamente el padre que disponga del cuidado paterno. 3. El juez puede limitar o excluir los derechos dos apartados 1 e 2, cuando necesario para el bien del hijo. 4. Los derechos del apartado 1 no existen cuando los conyujes vivirem apartados.

${ }_{267}$ Constituição da República Portuguesa - VII Revisão Constitucional. Disponível em http://www.parlamento.pt/RevisoesConstitucionais/Documents/Revisao2005/155a00.pdf,, $\quad$ acesso em $30 / 11 / 2009$.
} 
A família é tratada na Constituição da República Portuguesa em um único artigo, o $36^{\circ}$. Da leitura do dispositivo é nítida a proteção dada ao instituto do casamento. $\mathrm{O}$ texto constitucional não faz qualquer menção a outras formas de constituição familiar, contudo refere-se ao divórcio, à igualdade entre os cônjuges e os filhos, nascidos ou não de união matrimonial e o dever de manutenção e sustento dos filhos pelos pais.

Dispõe o artigo $36^{\circ}$ da Constituição Portuguesa: "1. Todos têm o direito de constituir família e de contrair casamento em condições de plena igualdade. 2. A lei regula os requisitos e os efeitos do casamento e da sua dissolução, por morte ou divórcio, independentemente da forma de celebração. 3. Os cônjuges têm iguais direitos e deveres quanto à capacidade civil e política e à manutenção e educação dos filhos. 4. Os filhos nascidos fora do casamento não podem, por esse motivo, ser objecto de qualquer discriminação e a lei ou as repartições oficiais não podem usar designações discriminiatórias relativas à filiação. 5. Os pais têm o direito e o dever de educação e manutenção dos filhos. 6. Os filhos não podem ser separados dos pais, salvo quando estes não cumpram os seus deveres fundamentais para com eles e sempre mediante decisão judicial. 7. A adopção é regulada e protegida nos termos da lei, a qual deve estabelecer formas céleres para a respectiva tramitação."

O Código Civil Português trata o direito de família em seu livro IV, sendo a filiação assunto de interesse para o presente trabalho, tratada no Título III, do qual destacamos, especialmente, o estudo do poder parental.

No artigo $1874^{\circ}$ o Código Civil Português, assim estabelece os deveres entre pais e filhos: "1. Pais e filhos devem-se mutuamente respeito, auxílio e assistência. 2. O dever de assistência compreende a obrigação de prestar alimentos e a contribuir, durante a vida em comum, de acordo com os recursos próprios, para os encargos da vida”.

Por sua vez, estabelecem os artigos $1877^{\circ}$ e $1878^{\circ}$ do Código Civil o poder paternal e seu conteúdo. Dispõe o artigo $1877^{\circ}$ : “Os filhos estão sujeitos ao poder paternal até a maioridade ou emancipação." Enquanto, o artigo $1878^{\circ}$, diz que: "Compete aos pais, no interesse dos filhos, velar pela segurança e saúde destes, prover ao seu sustento, dirigir a sua educação, representá-los, ainda que nascituros, e administrar os seus bens. 2. Os filhos devem obediência aos pais, porém, de acordo com a maturidade dos filhos, devem ter em conta a sua opinião nos assuntos familiares importantes e reconhecerlhes autonomia na organização da própria vida."

Código Civil Português. VARELA, Antunes e LIMA, Pires. Código Civil Anotado. Volume V. Coimbra Editora, Coimbra, 1995. 
Segundo Antunes Varela e Pires de Lima, o conteúdo do poder paternal estabelecido no artigo $1878^{\circ}$ “é a síntese do poder paternal dada no artigo 371-2 do Código francês, segundo o qual a autoridade pertence ao pai e à mãe, para proteger o filho na sua segurança, na sua saúde e na sua formação moral (sa moralité), acrescentando o $\S$ subseqüente que eles têm perante o filho o direito e o dever de guarda, de vigilância (de surveillance) e de educação." 268

De acordo com os autores, o poder paternal possui três características relevantes: a) um lado passivo para afirmar o poder dos pais, que se desdobra e corresponde a um dever de obediência por parte dos filhos, b) um caráter individual e progressivo da autonomização conquistada pelo menor no caminho da maioridade, os pais devem ouvir os filhos, na medida que tratam de assuntos de seus interesses, e tenham eles maturidade para opinar, c) autonomia dos filhos, que deve ser reconhecida na organização da própria vida, desde observadas as regras e disciplinas impostas pelos pais.

Nos artigos $1881^{\circ}, 1885^{\circ}$ e $1888^{\circ}$ do Código Civil, o legislador português estabelece os direitos e deveres dos pais no exercício do poder paternal, entre os quais o poder de representação, que compreende o exercício de todos os direitos e o cumprimento de todas as obrigações do filho, o dever de educação, que compreende a promoção do desenvolvimento físico, intelectual e moral dos filhos, de acordo com suas possibilidades e à adequada instrução geral e profissional, correspondente às aptidões e inclinações dos filhos e a educação religiosa (artigo $1886^{\circ}$ ) e a administração dos bens dos filhos, destacando o legislador os bens sobre quais os pais não detém a administração. ${ }^{269}$

\footnotetext{
${ }^{268}$ VARELA, Antunes e LIMA, Pires. Código Civil Anotado. Volume V. Coimbra Editora, Coimbra, 1995. Pág. 332.

${ }^{269}$ Artigo $1881^{\circ}$. 1. O poder de representação compreende o exercício de todos os direitos e o cumprimento de todas as obrigações do filho, exceptuados os actos puramente pessoais, aqueles que o menor tem o direito de praticar pessoal e livremente e os actos respeitantes a bens cuja administração não pertença aos pais. 2. Se houver conflito de interesses cuja resolução dependa de autoridade pública, entre qualquer dos pais e o filho sujeito ao poder patenal, ou entre os filhos, ainda que, neste caso, algum deles seja maior, são os menores representados por um ou mais curadores especiais nomeados pelo tribunal.

Artigo $1885^{\circ}$. 1. Cabe aos pais, de acordo com as suas possibilidades, promover o desenvolviemento físico, intelectual e moral dos filhos. 2. Os pais devem proporcionar aos filhos, em especial aos diminuídos física e mentalmente, adequada instrução geral e profissional, correspondente, na medida do possível, às aptidões e inclinações de cada um.

Artigo $1886^{\circ}$. Pertence aos pais decidir sobre a educação religiosa dos filhos menores de dezasseis anos.

Artigo $1888^{\circ}$. 1. Os pais não têm a adminitração: a) Dos bens do filho que procedam de sucessão na qual os pais tenham sido excluídos por indignidade ou deserdação, b) Dos bens que tenham advindo ao filho por doação ou sucessão contra a vontade dos pais, c) Dos bens deixados ou doados ao filho com exclusão da administração dos pais, d) Dos bens adquiridos pelo filho maior de dezasseis anos pelo seu trabalho. 2. A exclusão da administração, nos termos da alínea c0 do número anterior, é permitida mesmo relativamente a bens que caibam ao filho a título de legítima.
} 
A irrenunciabilidade, assim como no direito brasileiro é reconhecida como característica do poder paternl no direito português, conforme estabelece o artigo $1882^{\circ}$ : "Os pais não podem renunciar ao poder paternal nem a qualquer dos direitos que ele especialmente lhes confere, sem prejuízo do que neste código se dispõe acerca da adopção.

Quanto ao exercício do poder paternal, dispõe o artigo $1901^{\circ}$, que, na constância do casamento pertence aos pais, que, exercem o poder de comum acordo. Em caso de divergência poderão recorrer ao tribunal, que, tentará a conciliação, e, não sendo possível decidirá. Reconhece, pois, o legislador português a igualdade jurídica entre marido e mulher dentro da sociedade conjugal ${ }^{270}$.

Contudo, é possível o exercício do poder paternal por apenas um dos pais, no caso de impedimento do outro, assim entendido como ausência, incapacidade ou impedimento propriamente dito, nos termos do artigo $1903^{\circ}$ do Código Civil Português ${ }^{271}$.

No caso da filiação ser extramatrimonial, se tiver sido estabelecida apenas quanto a um dos progenitores, a este pertencerá o poder paternal (artigo 1910) e, quando estabelecida quanto a ambos os progenitores, o exercício do poder paternal pertencerá àquele que tiver a guarda. Há presunção legal que a mãe detém a guarda dos filhos, presunção só elidida judicialmente. Para o exercício do poder parental ser conjunto, os pais devem conviver maritalmente e assim o declarar perante o funcionário do registro civil (artigo $\left.1911^{\circ}\right)^{272}$.

Da leitura dos artigos supra mencionados podemos notar, mais uma vez, a priorização dada ao instituto do casamento pela legislação portuguesa. Aos filhos extramatrimoniais presume-se que seus progenitores não convivem maritalmente, logo, o exercício do poder será exclusivo da mãe, reputada com maiores ligações com o filho por conta da situação. Para o exercício do poder paternal conjunto pelos pais, necessário o

\footnotetext{
${ }^{270}$ Artigo $1901^{\circ}$. 1. Na constância do matrimónio o exercício do poder paternal pertence a ambos os pais. 2. Os pais exercem o poder paternal de comum acordo e, se este faltar em questões de particular importância, qualquer deles pode recorrer ao tribunal, que tentará a conciliação; se esta não for possível, o tribunal ouvirá, antes de decidir, o filho maior de catorze anos, salvo quando circunstâncias ponderosas o desaconselhem.

${ }^{271}$ Artigo $1903^{\circ}$. Quando um dos pais não puder exercer o poder paternal por ausência, incapacidade ou outro impedimento, caberá esse exercício unicamente ao outro progenitor.

${ }^{272}$ Artigo $1910^{\circ}$. Se a filiação de menor nascido fora do casamento se encontrar estabelecida apenas quanto a um dos progenitores, a este pertence o poder paternal.

Artigo $1911^{\circ}$. 1. Quando a filiação se encontre estabelecida relativamente a ambos os pais e estes não tenham contraído matrimônio após o nascimento do menor, o exercício do poder paternal pertence ao progenitor que tiver a guarda do filho. 2. Para os efeitos do número anterior presume-se que a mãe tem a guarda do filho; esta presunção só é ilidível judicialmente. 3. Se os progenitores conviverem maritalmente, o exercício do poder paternal pertence a ambos quando declararem, perante o funcionário do registro civil, ser essa a sua vontade; é aplicável, neste caso, com as necessárias adaptações, o disposto nos artigos $1901^{\circ}$ a $1904^{\circ}$.
} 
cumprimento de formalidade, perante o registro civil, com declaração que vivem maritalmente e que é sua vontade exercer conjuntamente tal múnus.

No caso de separação ou divórcio dos pais, ou ainda de anulação do casamento, estabelece o artigo $1905^{\circ}$ do Código Civil Português que o poder paternal será regulado por acordo dos pais, que atenda ao interesse do menor. $\mathrm{Na}$ falta de acordo, o tribunal decidirá, observando o interesse do menor, a quem será confiada a guarda, que, poderá inclusive ser conferida a terceiro, caso os pais não atendam às condições necessárias. O pai que não ficar com a guarda terá direito de visitas ${ }^{273}$.

Para a separação de fato, são aplicáveis as mesmas regras que para o divórcio (artigo $\left.1909^{\circ}\right)^{274}$.

Observam Antunes Varela e Pires de Lima, que, o legislador, com a Reforma de 1977 do Código Civil, não reproduziu expressamente que no caso de separação ou divórcio ambos os pais conservam, em relação aos filhos menores, o poder paternal, e acreditam ter sido tal missão intencional, tendo em vista o direito de visitas estabelecido na parte final do artigo, no número 3. Ressaltam o destaque dado pelo legislador ao interesse do menor, que pode impedir a homologação de acordo dos pais e a concessão da guarda a terceiros, quando os pais não atendam às condições necessárias. ${ }^{275}$

A idéia de exercício do poder paternal por apenas um dos pais no caso de separação ou divórcio é reforçada pelo disposto no artigo $1906^{\circ}$, que, destaca o exercício do poder ao progenitor a quem o filho foi confiado e o poder de vigilância da educação e condições da vida do filho, ao progenitor que não exerça o poder paternal ${ }^{276}$.

Na legislação portuguesa não há norma quanto ao exercício do poder paternal para os casos de novo casamento. Não prevê o Código Civil Português a família

\footnotetext{
${ }^{273}$ Artigo $1905^{\circ}$. 1. Nos casos de divórcio, separação judicial de pessoas e bens, declaração de nulidade ou anulação de casamento, o destino do filho, os alimentos a este devidos e a forma de os prestar serão regulados por acordo dos pais, sujeito a homologação do tribunal; a homologação será recusada se o acordo não corresponder ao interesse do menor. 2. Na falta de acordo, o tribunal decidirá de harmonia com o intesse do menor, podendo este ser confiado à guarda de qualquer dos pais ou, quando se verifique alguma das circunstâncias previstas no artigo $1918^{\circ}$, à guarda de terceira pessoa ou de estabelecimento de educação ou assistência. 3. No caso referido no número anterior será estabelecido um regime de visitas ao progenitor ou progenitores a quem não tenha sido confiada a guarda do filho, a menos que excepcionalmente o intresse deste o desaconselhe.

${ }^{274}$ Artigo $1909^{\circ}$. As disposições dos artigos $1905^{\circ}$ a $1908^{\circ}$ são aplicáveis aos cônjuges separados de fato.

${ }^{275}$ VARELA, Antunes e LIMA, Pires. Código Civil Anotado. Volume V. Coimbra Editora, Coimbra, 1995. Pág. 401.

${ }^{276}$ Artigo $1906^{\circ}$. 1. O poder paternal é exercido pelo progenitor a quem o filho foi confiado. 2. Os pais podem, todavia, acordar, nos termos do $\mathrm{n}^{\circ} 1$ do artigo anterior, ou, na falta de acordo, pode o tribunal decidir que a administração dos bens do filho seja exercida pelo progenitor a quem o menor não tenha sido confiado. 3. Ao progenitor que não exerça o poder paternal assite o poder de vigiar a educação e as condições de vida do filho.
} 
reconstituída, mas, na medida em que admite o divórcio, tal fato também será uma realidade no país.

Registramos, contudo, que diferentemente da legislação brasileira, não há qualquer impedimento expresso no ordenamento quanto à influência dos pais afins no exercício do poder paternal.

\section{ITÁLIA}

A legislação italiana será estudada por meio das normas contidas na Constituição da República e do Código Civil $^{277}$.

A família é tratada na Constituição da República Italiana especialmente em três artigos do $29^{\circ}$ ao $31^{\text {o278 }}$.

Da leitura dos dispositivos, assim como na legislação portuguesa, possível notar a proteção dada ao instituto do casamento, uma vez que não há menção no texto constitucional a outras formas de constituição familiar.

Contudo reconhece a Constituição Italiana a igualdade entre os filhos matrimoniais e não matrimoniais e estabelece os deveres dos pais com relação aos filhos, especialmente quanto à manutenção, educação e instrução. Oferece, ainda ajuda econômica às famílias numerosas e estende a proteção à maternidade, infância e juventude.

Reconhece, ainda, a Constituição Italiana a igualdade entre os cônjuges na direção da sociedade conjugal.

O Código Civil Italiano trata da família em seu primeiro livro, que compreende os artigos $1^{\circ}$ ao $455^{\circ}$. Para o presente estudo, interessa, especialmente, os laços de parentesco e relações de filiação, em como a autoridade parental, contidas nos Títulos V e IX respectivamente.

277 La $\quad$ Constituzione $\quad$ Italian. $\quad$ Disponível em http://www.cjf.gov.br/Bvirtual/asp/saidaCat.asp?cod=9codintermed=18\&id=ita, acesso em 07/12/2009.

PERLINGIERI, Pietro. Codice Civile Annotato com la dottrina e la giurispudenza. Libro primo,, UTET, Torino, 1981.

278 Artícolo 29. La Repubblica riconosce i diritti della famiglia come società naturale fondata sul matromonio. Il matrimonio è ordinato sull'uguaglianza morale e giuridica dei coniugi, com i limiti stabiliti dalla legge a garanzia dell'unità familiare.

Artícolo 30. É dovere e diritto dei genitori mantenere, instruire ed educare i figli, anche se nati fuore del matrimonio. Nei casi di incapacita dei genitori, la legge provvede a che siano assolti i loro compiti. La legge assicura ai figli nati fuori del matrimonio ogni tutela giuridica e sociale, compatibile com i diritti dei membri della familiglia legittima. La legge detta Le norme e i limiti per la ricerca della paternità.

Artícolo 31. La Repubblica agevola com misure economiche e altre provvidenze la formazione della famiglia e l'adempimento dei compiti relativi, com particolare riguardo alle famiglie numerose, Protegge la maternità, l'infanzia e la gioventù, favorendo gli istituti necessari a tale scopo. 
No artigo 78, reconhece o Código Civil Italiano a afinidade, como o vínculo estabelecido entre o cônjuge e os parentes do outro, na mesma linha e grau de parentesco que o cônjuge estabelece com seus familiares. Tal vínculo, não se extingue nem com a morte do cônjuge. ${ }^{279}$

Possível dizer que tal artigo possibilita o reconhecimento do vínculo de afinidade entre o cônjuge e os filhos do outro, no caso de famílias formadas após o divórcio.

O Título IX, que compreende os artigos 315 ao 342, trata da autoridade dos genitores.

Estabelece o artigo 315 que o filho deve respeito ao genitor e devem contribuir para a própria manutenção e a de sua família ${ }^{280}$. Segundo Pietro Perlingieri, procurou o legislador proteger prioritariamente o instituto da família, o superior interesse da família, antes do interesse do menor. Assim o legislador retirou qualquer ingerência ou obstáculo ao exercício da autoridade dos genitores. ${ }^{281}$

De fato, a legislação italiana, estabelece aos filhos, mais deveres que as demais legislações analisadas, que, no exercício da autoridade parental, priorizam o melhor interesse do menor.

Os deveres dos pais em relação aos filhos encontram-se nos artigos 277 e 279 do Código Civil Italiano, quando o legislador trata dos efeitos do reconhecimento da filiação, que compreendem a manutenção, a instrução e a educação do filho, assim como, a tutela de seus interesses patrimoniais ${ }^{282}$.

\footnotetext{
${ }^{279}$ Artícolo 78 (Affinità). L'affinità è Il vincolo tra um coniuge e i parenti dell'altro coniuge. Nella línea e nel grado in cui taluno è parente d'uno dei coniugi, egli è affine dell'altro. Coniuge. L'affinità non cessa per la morte, anche senza prole, del coniuge da cui deriva, salvo Che per alcuni effetti specialmente determinati. Cessa se Il matrimonio è dichiarato nullo, salvi gli effeti di cui all'art. 87, n4.

${ }^{280}$ Artícolo 315. (Doveri del figlio verso i genitori). Il figlio deve rispettare i genitori e deve contribuire, in relazione alle proprie sostanze e al próprio reddito, al mantenimento della famiglia finché convive com essa.

${ }^{281}$ PERLINGIERI, Pietro. Codice Civile Annotato com la dottrina e la giurispudenza. Libro primo,, UTET, Torino, 1981, pág. 730.

${ }^{282}$ Articolo 277. (effeti della sentenza). La sentenza che dichiara la filiazone naturale produce gli effetti del riconoscimento. Il giudice può anche dare i provvedimenti che stima utili per Il mantenimento, l'istruzione e l'educazione del figlio e per la tutela degli interessi patrimoniali di lui.

Articolo 279 (Responsabilità per il mantenimento e l'educazione). In ogni i cui non può proposrsi l'azione per dichiarazione giudiziale di paternità o di maternità, il figlio natural può agire per ottenere il mantenimento, l'instruzione e l'educazione $(580,594)$. Il figlio naturale se maggiorenne e in stato di bisogno può agire per ottenere gli alimenti. L'azione è ammessa previa autorizzazione del giudice ai sensi dell'art. 274. L'azione può essere promossa nell'interesse del figlio minore da um curatore speciali nominato dal giudice su richiesta del pubblico ministero o del genitore che esercita la potestà.
} 
Quanto ao exercício da autoridade paternal, estabelece o artigo 316 do Código Civil Italiano ${ }^{283}$ que o filho está sujeito ao poder até a maioridade ou sua emancipação. A autoridade deverá ser exercida em comum acordo pelos genitores e, em caso de divergência quanto a alguma questão importante, qualquer dos pais poderá recorrer ao juiz. Entretanto, se a questão oferecer perigo iminente de grave prejuízo ao menor, o pai pode adotar providências urgentes e inadiáveis.

Não sendo este o caso, o juiz, depois de ouvir os pais e filho, se maior de 14 anos, sugere sugestões que considere mais úteis ao interesse do filho e à unidade familiar, respeitando, na medida do possível, a autonomia da família. Mas, se o desacordo persistir, determina o artigo 316 que o juiz, ao invés de decidir confie ao progenitor que lhe pareça mais idôneo para cuidar dos interesses do filho, o poder de decisão. Mais uma vez, verifica-se, a importância dada ao legislador à autonomia da família.

No caso de impedimento ou incapacidade de um dos genitores, o exercício da autoridade parental será exercida de modo exclusivo pelo outro genitor. Esclarece o legislador italiano que a autoridade comum dos genitores não se extingue com a separação, o divórcio ou anulação do matrimônio, que será exercida de acordo com o disposto na legislação. Estes os termos do artigo 317 do Código Civil Italiano ${ }^{284}$.

Dos termos do artigo 317, percebe-se que o legislador italiano inicialmente dissocia o exercício da autoridade parental da existência do casamento dos pais.

Para o caso de separação e divórcio, o artigo 155 do Código Civil Italiano estabelece como se dará o exercício da autoridade parental ${ }^{285}$. De acordo com a ${ }^{283}$ Articolo 316 . (Esercizio della potestà dei genitore). Il figlio è soggetto allá potestà dei genitori sino all'età
maggiore o all'emancipazione. La potestà è esercitat di comune accordo da entrambi i genitori. In caso di
contrasto su questioni di particolare importanza ciascuno dei genitori può ricorrere senza formalità al giudice
indicando i provvedimenti Che ritieni piú idonei. Se sussiste um incombente pericolo di um grave
pregiudizio per Il figlio, Il padre può adottare i provvedimenti urgenti Ed indifferibili. Il giudice, sentiti i
genitore ed figlio, se maggiore degli anni quattordici, suggerisce Le determinazioni che ritieni piú utili
nell'interesse del figlio e dell'unità familiare. Se Il contrasto permane Il giudice attriuisce Il podere di
decisione a quello dei genitori che, nel singolo caso, ritiene Il piú idôneo a curare l'interesse del figlio.
${ }_{284}$ Artícolo 317 (Impedimento di uno genitori), Nel caso di lontananza, di incapacitá o di altro impedimento
che renda impossibile ad uno dei genitori l'esercizio della potestà, questa è esercitata in modo esclusivo
dall'altro. La potestà comune dei genitori non cessa quando, a seguito di separazione, di scoglimento, di
annullamneto o di cessazione degli effetti civili del matrimonio, i figli vengono affitadi ad uno di essi.
L'esercizio della potestà é regolato, in tali casi, secondo quanto disposto nell'articolo 155 .
285 Articolo 155 . (Provvedimenti riguardo ai figli). Il giudice che pronunzia la separazione dichiara a quale
dei coniugi i figli sono affidati e adotta ogni altro provvedimentto relativo alla prole, com esclusivo
riferimento all'intersse morale e materiale di essa. In particolare Il giudice stabilisce la misura e il modo com
cui l'altro coniuge deve contribuire al mantenimento, all'instruzione eaal'educazione dei figli, nonché Le
modalitá di esercizio dei suoi diritti Nei rapporti com essi. Il coniuge cui sono affidati i figli, salva diversa
disposizione del giudice, há l'esercizio esclusivo della potestà su di essi; egli deve attenersi alle condizioni
determinate dal giudice. Salvo che sai diversamente stabilito, Le decisioni di maggiori interesse per i figli 
regra contida no artigo, o juiz que declara a separação deverá decidir a qual cônjuge o filho será confiado atendendo exclusivamente aos interesses morais e materiais da prole. O juiz deverá estabelecer a medida e o modo que o cônjuge deverá contribuir com o outro para a manutenção, instrução e educação dos filhos.

Ao cônjuge a quem foi confiado o filho, salvo disposição diversa do juiz, compete o exercício exclusivo da autoridade parental, entretanto, as decisões de maior interesse para o filho, deverão ser tomadas pelos pais, de comum acordo.

O cônjuge que não tiver o exercício da autoridade parental, incumbirá o dever de vigilância da instrução e educação do filho, podendo recorrer ao juiz quando alguma decisão tenha sido prejudicial ao interesse do menor.

Ao decidir sobre o exercício da autoridade parental e as demais questões relativas manutenção do filho, o juiz deve observar o acordo realizado entre os cônjuges, podendo, contudo`, decidir de forma distinta.

Por motivo grave, o juiz poderá determinar que a autoridade seja concedida a um terceira pessoa ou a um instituto de educação.

Questiona Pietro Perlingieri a ausência de disposição quanto à opinião do filho menor que tenha capacidade de discernimento para escolher com qual dos pais quer ficar $^{286}$.

Estabelece, ainda, o legislador que o direito de habitação da residência familiar é preferencial do cônjuge a quem o filho foi confiado.

A administração dos bens do menor também será decidida pelo juiz, que poderá determinar que seja exercida conjuntamente pelos pais.

A decisão quanto ao exercício da autoridade parental, a confiança do menor a um dos pais e as medidas de contribuição podem ser revistas a qualquer tempo a pedido dos cônjuges.

sono adottate da entrambi i coniugi. Il coniuge cui i figli non siano affidati há Il diritto e Il dovere di vigilare sulla loro istrzione Ed educazione e puó ricorrere al giudice quando ritenga che siano state assunte decisioni pregiudizievoli al loro interesse. L'abitazione nella casa familiare spetta di preferenza, e ove sai possible, al coniuge cui vengono affidati i figli. Il giudice dà inoltre disposizione circa l'amministrazione dei Beni dei figli e, nell'ipotesi che l'esercizio della potestà sia affidato ad entrambi i genitori, Il concorso degli stessi al godimento dell'usufrutto legale. In ogni caso Il giudice può per gravo motivi ordinari che la prole sai collocata presso uma terza persona o, nella impossibilita, in um istituto di educazione. Nell'emanare i provvedimenti relativi all'affidamento dei figli e al contributo al loro mantenimento, Il giudice deve tener conto dell'accordo fra Le parti: i provvedimenti possono essere diversi rispetto alle domande delle parti o al loro accordo, ed emessi dopo l'assunzione di mezzi di prova dedotti dalle parti o disposti d'ufficio dal giudice. I coniugi hanno diritto di chierdere in ogni tempo la revisione delle disposizione concernenti l'affidamento dei figli, l'atribuzione dell'esercizio della potestà sudi essi e Le disposizione relative alla misura e alle modalità del contributo.

${ }^{286}$ PERLINGIERI, Pietro. Codice Civile Annotato com la dottrina e la giurispudenza. Libro primo,, UTET, Torino, 1981, pág. 481. 
No artigo 317 bis $^{287}$, traz o Código Civil Italiano, que pertence ao genitor que reconheceu o filho natural o exercício da autoridade parental. Se os genitores reconheceram de comum acordo o filho, a autoridade será por eles exercida conjuntamente. Mas, se os genitores não convivem, a autoridade será exercida por aquele que convive com o filho. Esclarece, conduto, o legislador que, no interesse exclusivo do filho, o juiz pode decidir de forma diferente, nomeando-lhe inclusive um tutor. Ao genitor que não for conferido o exercício da autoridade, tem o poder de vigiar a instrução, educação e condições de vida do filho menor.

Segundo Pietro Perlingieri ${ }^{288}$, o artigo segue a tendência doutrinária de equiparar filiação legítima e filiação natural, tanto que, permitiu o legislador aplicar à filiação natural o disposto para a filiação legítima, especialmente quanto à posição do pai e da mãe natural quanto ao exercício da autoridade em relação ao seu filho menor.

Tal qual a legislação portuguesa, a italiana, que tem como base da família o casamento, embora admita o divórcio, não traz qualquer referência às famílias formadas após o divórcio e a possibilidade de atuação dos pais afins em relação aos filhos afins, embora, tal fato, seja também uma realidade naquele pais.

\section{CHILE}

A legislação chilena será estudada, assim como os demais países apresentados até então, pela análise da Constituição da República do Chile e do Código Civil Chileno. ${ }^{289}$

A família é tratada na Constituição da República do Chile em apenas um artigo, o $1^{\circ}$, que diz ser a família o núcleo fundamental da sociedade chilena. Dispõe o artigo ser dever do Estado dar proteção à família e promover o seu fortalecimento.

${ }^{287}$ Artícolo 317 bis (Esercício della potestà). Al genitore Che há riconosciuto Il figlio naturale spetta la potestà su di lui. Se il riconoscimento è fatto da entrambi i genitori, l'esercizio della potestà spetta congiuntamente ad entrambi qualora siano conviventi. Si applicano Le disposizione dell'articolo 316 . Se i genitori non convivono l'esercizio della potestà spetta al genitore col quale Il figlio convive ovvero, se non convive com alcuno di essi, al primo che há fatto il riconoscimento. Il giudice, nell'esclusivo interesse del figlio, púo dispore diversamente; púo anche escludere daal'esercizio della potestà entrambi i genitori, provvedendo alla nomina di um tutore. Il genitore che non esercita la potestà há Il potere di vigilare sulla istruzione, suul'educazione e sulle condizioni di vita del figlio minore.

${ }^{288}$ PERLINGIERI, Pietro. Codice Civile Annotato com la dottrina e la giurispudenza. Libro primo,, UTET, Torino, 1981, pág. 741/742.

289 Constituición Política de La Republica del Chile. Decreto $\mathrm{n}^{\circ}$ 1,150/1980. Ministerio del Interior. Disponível em http://www.direito.adv.br/constitu.htm, acesso em 19/11/2009.

$\begin{array}{lllll}\text { Código Civil } & \text { de } & \text { Chile. } & \text { Disponível } & \mathrm{em}\end{array}$ http://www.paginaschile.cl/biblioteca_juridica/codigo_civil/codigo_civil_de_chile.htm, acesso em 19/11/2009. 
Estabelece, ainda, estar o Estado ao serviço da pessoa humana, sendo sua finalidade promover o bem comum. ${ }^{290}$

Como podemos notar, a Constituição Chilena enaltece a pessoa humana e a promoção de sua dignidade e bem-estar dentro da sociedade. A proteção pelo Estado é dada à família de forma ampla, sem qualquer preferência quanto ao tipo de constituição familiar. O texto constitucional não descreve as formas familiares que reconhece, apenas orienta que, independente da formação, o grupo familiar deve ser protegido.

No Código Civil Chileno, as disposições atinentes à família encontram-se no Livro I, destacamos, especialmente os títulos, VII - da filiação, IX - dos direitos e obrigações entre pais e filhos e X-do pátrio poder, assuntos relevantes para o presente estudo.

Estabelece o artigo 222 do Código Civil Chileno que os filhos devem respeito e obediência aos seus pais, que, em contrapartida devem observar o melhor interesse do menor, buscando sua realização espiritual e material, guiando-o no exercício dos direitos fundamentais. ${ }^{291}$

Como deveres dos pais, estabelece também o Código Civil Chileno, a manutenção, criação e educação dos filhos menores, assim como orientá-los para o seu pleno desenvolvimento em todas as fases de sua vida (artigos 230 e 236). ${ }^{292}$

Para os filhos, há também o dever de cuidar dos pais na velhice ou se doentes, ou em qualquer outra situação que requeira atenção dos filhos (artigo 223). ${ }^{293}$

\footnotetext{
${ }^{290}$ Art. 1. Los hombres nascen libres e iguales em dignidad y derechos. La família es el núcleo fundamental de la sociedad. El Estado reconoce y ampara a los grupos intermédios a través de los cuales se organiza y estructura la sociedad y lês garantiza la adecuada autonomia para cumplir sus proprios fines específicos. El Estado está al servicio de la persona humana y su finalidad es promover el bien común, para lo cual debe contribuir a crear las condiciones sociales que permitan a todos y a cada uno de los integrantes de la comunidad nacional su mayor realización espiritual y material posible, con pleno respeto a los derechos y garantías que esta Constituición establece. Es deber del Estado resguardar la seguridad nacional, dar proteción a la población y a familia de todos los sectores de la Nación y asegurar el derecho de las personas a participar com igualdad de oportunidades em la vida nacional.

291 Art. 222. Los hijos deben respeto y obediencia a sus padres. La preocupación fundamental de los padres es el interés superior del hijo, para lo cual procurarán su mayor realización espiritual y material posible, y lo guiarán en el ejercicio de los derechos esenciales que emanan de la naturaleza humana de modo conforme a la evolución de sus facultades.

${ }^{292}$ Art. 230. Los gastos de educación, crianza y establecimiento de los hijos son de cargo de la sociedad conyugal, según las reglas que tratando de ella se dirán. Si no la hubiere, los padres contribuirán en proporción a sus respectivas facultades económicas. En caso de fallecimiento del padre o madre, dichos gastos corresponden al sobreviviente.

Art. 236. Los padres tendrán el derecho y el deber de educar a sus hijos, orientándolos hacia su pleno desarrollo en las distintas etapas de su vida.

${ }^{293}$ Art. 223. Aunque la emancipación confiera al hijo el derecho de obrar independientemente, queda siempre obligado a cuidar de los padres en su ancianidad, en el estado de demencia, y en todas las circunstancias de la vidaen que necesitaren sus auxilios.
} 
O pátrio poder é exercido pelos pais conjuntamente na constância da sociedade conjugal, mas, no caso de falecimento caberá exclusivamente ao sobrevivente. Da mesma forma, o poder será exercido exclusivamente por um dos pais, quando o filho extramatrimonial tiver sido reconhecido apenas pelo pai ou pela mãe (artigo 224). ${ }^{294}$

No caso de os pais viverem separados, caberá à mãe a guarda dos filhos, podendo, contudo, existir entre os pais acordo que tal múnus caberá ao pai. Ainda, no caso de não ser atendido o melhor interesse do menor, poderá existir determinação judicial para que a guarda seja atribuída ao outro pai, ou ainda, ser confiada a uma terceira pessoa (artigos 225 e 226 do Código Civil Chileno) ${ }^{295}$.

Mas, ao pai ou à mãe que não tenha sido atribuída a guarda do menor é mantido o dever de manter uma relação direta e regular, de forma conveniente para o menor. Tal direito apenas será restringido se manifestamente prejudicar o bem-estar do filho (artigo 229 do Código Civil Chileno). ${ }^{296}$ Como visto, o ordenamento prevê a obrigação de visitas do pai que não detém a guarda.

O legislador chileno previu expressamente as situações em que pais que detenham a guarda sejam casados com novos parceiros e estabeleceu que, nestes casos, os

Tienen derecho al mismo socorro todos los demás ascendientes, en caso de inexistencia o de insuficiencia de los inmediatos descendientes.

294 Art. 224. Toca de consuno a los padres, o al padre o madre sobreviviente, el cuidado personal de la crianza y educación de sus hijos.

El cuidado personal del hijo no concebido ni nacido durante el matrimonio, reconocido por uno de los padres, corresponde al padre o madre que lo haya reconocido. Si no ha sido reconocido por ninguno de sus padres, la persona que tendrá su cuidado será determinada por el juez.

295 Art. 225. Si los padres viven separados, a la madre toca el cuidado personal de los hijos. No obstante, mediante escritura pública, o acta extendida ante cualquier oficial del Registro Civil, subinscrita al margen de la inscripción de nacimiento del hijo dentro de los treinta días siguientes a su otorgamiento, ambos padres, actuando de común acuerdo, podrán determinar que el cuidado personal de uno o más hijos corresponda al padre. Este acuerdo podrá revocarse, cumpliendo las mismas solemnidades. En todo caso, cuando el interés del hijo lo haga indispensable, sea por maltrato, descuido u otra causa calificada, el juez podrá entregar su cuidado personal al otro de los padres. Pero no podrá confiar el cuidado personal al padre o madre que no hubiese contribuido a la mantención del hijo mientras estuvo bajo el cuidado del otro padre, pudiendo hacerlo. Mientras una subinscripción relativa al cuidado personal no sea cancelada por otra posterior, todo acuerdo o resolución será inoponible a terceros. Art. 226. Podrá el juez, en el caso de inhabilidad física o moral de ambos padres, confiar el cuidado personal de los hijos a otra persona o personas competentes. En la elección de estas personas se preferirá a los consanguíneos más próximos, y sobre todo, a los ascendientes.

${ }^{296}$ Art. 229. El padre o madre que no tenga el cuidado personal del hijo no será privado del derecho ni quedará exento del deber, que consiste en mantener con él una relación directa y regular, la que ejercerá con la frecuencia y libertad acordada con quien lo tiene a su cargo, o, en su defecto, con las que el juez estimare conveniente para el hijo.

Se suspenderá o restringirá el ejercicio de este derecho cuando manifiestamente perjudique el bienestar del hijo, lo que declarará el tribunal fundadamente. 
novos cônjuges somente poderão ter o menor em lugares comuns, com o consentimento de seu cônjuge (artigo 228 do Código Civil). ${ }^{297}$

Contudo possibilita o legislador chileno, em caso de necessidade, a adoção de medidas por terceiras pessoas que estejam na companhia do menor, na ausência dos pais, presumindo a autorização destes. $\mathrm{O}$ fato deverá ser imediatamente comunicado aos pais (artigo 241) $)^{298}$.

No título dedicado ao pátrio poder, o legislador chileno destaca os direitos e deveres dos pais em relação aos bens dos filhos menores não emancipados ${ }^{299}$, já que, os direitos e deveres decorrentes da relação paterno-filial se esgotaram no Título IX Das obrigações entre pais e filhos.

Como visto, a legislação chilena, ainda que de forma limitada confere direitos aos pais afins nas famílias formadas após o divórcio ou morte, legitimando, ainda, a conduta de terceiros, aí incluídos os pais afins, que se encontrem, em determinadas situaçãoes, ante a ausência dos pais, responsáveis pelos menores.

\section{ARGENTINA}

A legislação argentina será estudada através da Constituição da Nação Argentina e do Código Civil Argentino ${ }^{300}$.

A Constituição da Nação Argentina traz de forma generalizada a proteção à família, sem dedicar artigo especial ao tema. No artigo 14 há menção quanto ao dever do Estado de proteger integralmente a família, e no artigo 19 consta a obrigação de promover o desenvolvimento humano e assegurar a participação da família e da sociedade na promoção nos valores democráticos, e a igualdade de oportunidades e possibilidades,

\footnotetext{
297 Art. 228. La persona casada a quien corresponda el cuidado personal de un hijo que no ha nacido de ese matrimonio, sólo podrá tenerlo en el hogar común, con el consentimiento de su cónyuge.

${ }^{298}$ Art. 241. Si el hijo de menor edad ausente de su casa se halla en urgente necesidad, en que no puede ser asistido por el padre o madre que tiene su cuidado personal, se presumirá la autorización de éste o ésta para las suministraciones que se le hagan, por cualquier persona, en razón de alimentos, habida consideración de su posición social.

El que haga las suministraciones deberá dar noticia de ellas al padre o madre lo más pronto que fuere posible. Toda omisión voluntaria en este punto hará cesar la responsabilidad. Lo dicho del padre o madre en los incisos precedentes se extiende en su caso a la persona a quien, por muerte o inhabilidad de los padres, toque la sustentación del hijo.

${ }^{299}$ Art. 243. La patria potestad es el conjunto de derechos y deberes que corresponden al padre o a la madre sobre los bienes de sus hijos no emancipados. La patria potestad se ejercerá también sobre los derechos eventuales del hijo que está por nacer.

300 Constituición de la Nación Argentina. Disponível em http://www.direito.adv.br/constitu.htm, acesso em 19/11/2009.

Codigo Civil de la Republica Argentina. Disponível em http://www.redetel.gov.ar/Normativa/Archivos\%20de\%20Normas/CodigoCivil.htm, acesso em 19/11/2009.
} 
sem discriminação ${ }^{301}$. A proteção à família é ampla e não há preferência por qualquer tipo de constituição familiar.

O Código Civil Argentino trata em seu Livro Primeiro, Seção Segunda, dos 'Direitos pessoais e das relações de família'. Para o presente estudo, destacamos especialmente a análise do Título II - Da filiação, Título III - Poder Paternal.

Inicialmente, ressaltamos que a igualdade entre os filhos matrimoniais, extramatrimoniais e adotivos é reconhecida pelo Código Civil Argentino em seu artigo $240 . .^{302}$

Destacamos que o legislador argentino, reconhece o parentesco por afinidade como o vínculo estabelecido entre o cônjuge e os parentes do outro, há expresso reconhecimento da relação entre padrastos e madrastas e enteados, no caso de existir matrimônio precedente (artigo 363 do Código Civil Argentino) ${ }^{303}$.

Reconhece, pois, expressamente, o legislador argentino a possibilidade de formação das famílias reconstituídas.

Estabelece o artigo 264 do Código Civil Argentino ${ }^{304}$ ser o pátrio poder o conjunto de direitos e deveres que correspondem aos pais sobre a pessoa e os bens dos

301 Art. 14. El Estado otorgará los beneficios de la seguridad social, que tendrá carácter de integral e irrenunciable. En especial, la ley establecerá: el seguro social obligatorio, que estará a cargo de entidades nacionales o provinciales con autonomía financiera y económica, administradas por los interesados con participación del estado, sin que pueda existir superposición de aportes, jubilaciones y pensiones móviles; la protección integral de la familia; la defensa del bien de familia; la compensación económica familiar y el acceso a una vivienda digna.

Art. 19. Proveer lo conducente al desarrollo humano, al progreso económico con justicia social, a la productividad de la economía nacional, a la generación de empleo, a la formación profesional de los trabajadores, a la defensa del valor de la moneda, a la investigación y desarrollo científico y tecnológico, su difusión y aprovechamiento. (...) Sancionar leyes de organización y de base de la educación que consoliden la unidad nacional respetando las particularidades provinciales y locales; que aseguren la responsabilidad indelegable del estado, la participación de la familia y la sociedad, la promoción de los valores democráticos y la igualdad de oportunidades y posibilidades sin discriminación alguna; y que garanticen los principios de gratuidad y equidad de la educación pública estatal y la autonomía y autarquía de las universidades nacionales.

${ }^{302}$ Art.240.- La filiación puede tener lugar por naturaleza o por adopción. La filiación por naturaleza puede ser matrimonial o extramatrimonial.

La filiación matrimonial y la extramatrimonial, así como la adoptiva plena, surten los mismos efectos conforme a las disposiciones de este Código.

${ }^{303}$ Art.363.- La proximidad del parentesco por afinidad se cuenta por el número de grados en que cada uno de los cónyuges estuviese con sus parientes por consanguinidad. En la línea recta, sea descendente o ascendente, el yerno o nuera están recíprocamente con el suegro o suegra, en el mismo grado que el hijo o hija, respecto del padre o madre, y así en adelante. En la línea colateral, los cuñados o cuñadas entre sí están en el mismo grado que entre sí están los hermanos o hermanas. Si hubo un precedente matrimonio, el padrastro o madrastra en relación a los entenados o entenadas, están recíprocamente en el mismo grado en que el suegro o suegra en relación al yerno o nuera.

${ }^{304}$ Art.264.- La patria potestad es el conjunto de deberes y derechos que corresponden a los padres sobre las personas y bienes de los hijos, para su protección y formación integral, desde la concepción de éstos y mientras sean menores de edad y no se hayan emancipado. Su ejercicio corresponde: 
filhos, para sua proteção e formação integral até que atinjam a maioridade. É nítida a intenção do legislador em privilegiar o menor interesse do menor.

O mesmo artigo estabelece que o exercício do pátrio poder corresponde aos pais conjuntamente, quando se tratar de filhos matrimoniais, que os pais convivam maritalmente. Neste caso, presume-se que os atos de um dos pais conta com o consentimento do outro.

No caso de separação de fato, separação judicial, divórcio ou anulação do matrimônio, o exercício será atribuído ao pai ou a mãe, sem prejuízo do direito do outro manter contato direto com o menor e supervisionar sua educação. Dispõe o artigo 206 do Código $\mathrm{Civil}^{305}$ que os filhos menores de 05 anos ficarão sob responsabilidade da mãe e, que os maiores de 05 anos, na falta de acordo dos cônjuges, o juiz atribuirá o exercício àquele que considere mais idôneo.

Registra, ainda, o legislador que os pais continuarão sujeitos a todas as obrigações relativas aos filhos depois da separação ou divórcio. Dissocia, pois, o pátrio poder da situação conjugal dos pais.

No caso de morte ou ausência de um dos pais o exercício do pátrio poder caberá exclusivamente ao outro.

Quanto aos filhos extramatrimoniais estabelece o legislador que, se reconhecido apenas por um dos pais, a este caberá exclusivamente o exercício do pátrio

1ro. En el caso de los hijos matrimoniales, al padre y a la madre conjuntamente, en tanto no estén separados o divorciados, o su matrimonio fuese anulado. Se presumirá que los actos realizados por uno de ellos cuenta con el consentimiento del otro, salvo en los supuestos contemplados en el art. 264, quater, o cuando mediare expresa oposición;

2do. En caso de separación de hecho, separación personal, divorcio vincular o nulidad de matrimonio, al padre o madre que ejerza legalmente la tenencia, sin perjuicio del derecho del otro de tener adecuada comunicación con el hijo y de supervisar su educación;

3ro. En caso de muerte de uno de los padres, ausencia con presunción de fallecimiento, privación de la patria potestad, o suspensión de su ejercicio, al otro;

4to. En el caso de los hijos extramatrimoniales, reconocidos por uno solo de los padres, a aquel que lo hubiere reconocido;

5to. En el caso de los hijos extramatrimoniales reconocidos por ambos padres, a ambos, si convivieren y en caso contrario, a aquel que tenga la guarda otorgada en forma convencional, o judicial, o reconocida mediante información sumaria;

6to. A quien fuese declarado judicialmente el padre o madre del hijo, si no hubiese sido voluntariamente reconocido.

305 Art.206.- Separados por sentencia firme, cada uno de los cónyuges podrá fijar libremente su domicilio o residencia. Si tuviese hijos de ambos a su cargo se aplicarán las disposiciones relativas al régimen de patria potestad.

Los hijos menores de 5 años quedarán a cargo de la madre, salvo causas graves que afecten el interés del menor. Los mayores de esa edad a falta de acuerdo de los cónyuges, quedarán a cargo de aquel a quien el juez considere más idóneo. Los progenitores continuarán sujetos a todas las cargas y obligaciones respecto de sus hijos. 
poder. E, se reconhecido pelos dois, caberá a ambos o exercício, caso convivam maritalmente e, em caso contrário, àquele que tenha sido conferida a guarda.

$\mathrm{Na}$ hipótese de ambos os pais sejam incapazes ou estejam privados do pátrio poder, aos filhos menores será nomeado um tutor.

Dispõe o artigo 264 ter. $^{306}$ que, em caso de desacordo entre os pais no exercício do pátrio poder, qualquer um deles poderá recorrer ao juiz, que resolverá da forma mais conveniente, de acordo com o interesse do menor, que, se já tiver discernimento suficiente, poderá ser ouvido. Caso os desentendimentos sejam constantes, pelo prazo de até dois anos, poderá o juiz distribuir entre os pais as funções relativas ao exercício do pátrio poder.

Quanto ao conteúdo do pátrio poder, os artigos 265 e 266 estabelecem que os filhos estão sob a autoridade e cuidado dos pais, que têm a obrigação e o direito de criá-los, alimentá-los e educá-los conforme suas condições. Em contrapartida, devem os filhos respeito e obediência aos pais e deles cuidar na sua velhice ou quando doentes. ${ }^{307}$

Prevê também o Código Civil Argentino, quanto ao pátrio poder, o direito de representação dos pais (artigo 274), o poder de correção de forma moderada (artigo 278), o poder de exigir que os filhos prestem colaboração próprias da idade (art. 277) e, aos filhos, a necessidade de autorização para deixar o lar familiar (art. 275). ${ }^{308}$

\footnotetext{
${ }^{306}$ Art.264 ter.- En caso de desacuerdo entre el padre y la madre, cualquiera de ellos podrá acudir al juez competente, quien resolverá lo más conveniente para el interés del hijo, por el procedimiento más breve previsto por la ley local, previa audiencia de los padres con intervención del Ministerio Pupilar. El juez, podrá, aun de oficio, requerir toda la información que considere necesaria, y oír al menor, si éste tuviese suficiente juicio, y las circunstancias lo aconsejaren. Si los desacuerdos fueren reiterados o concurriere cualquier otra causa que entorpezca gravemente el ejercicio de la patria potestad, podrá atribuirlo total o parcialmente a uno de los padres o distribuir entre ellos sus funciones, por el plazo que fije, el que no podrá exceder de dos años.

307 Art.265.- Los hijos menores de edad están bajo la autoridad y cuidado de sus padres. Tienen éstos la obligación y el derecho de criar a sus hijos, alimentarlos y educarlos conforme a su condición y fortuna, no sólo con los bienes de los hijos, sino con los suyos propios.

Art.266.- Los hijos deben respeto y obediencia a sus padres. Aunque estén emancipados están obligados a cuidarlos en su ancianidad y en estado de demencia o enfermedad y a proveer a sus necesidades, en todas las circunstancias de la vida en que les sean indispensables sus auxilios.

Tienen derecho a los mismos cuidados y auxilios los demás ascendientes.

${ }^{308}$ Art.274.- Los padres, sin intervención alguna de sus hijos menores, pueden estar en juicio por ellos como actores o demandados, y a nombre de ellos celebrar cualquier contrato en los límites de su administración señalados en este Código.

Art.278.- Los padres tienen la facultad de corregir o hacer corregir la conducta de sus hijos menores. El poder de corrección debe ejercerse moderadamente, debiendo quedar excluidos los malos tratos, castigos o actos que lesionen o menoscaben física o psíquicamente a los menores. Los jueces deberán resguardar a los menores de las correcciones excesivas de los padres, disponiendo su cesación y las sanciones pertinentes si correspondieren.

Art.277.- Los padres pueden exigir que los hijos que están bajo su autoridad y cuidado les presten la colaboración propia de su edad, sin que ellos tengan derecho a reclamar pago o recompensa.

Art.275.- Los hijos menores no pueden dejar la casa de sus progenitores, o aquella que éstos les hubiesen asignado, sin licencia de sus padres.
} 
Como visto a legislação argentina traz de forma detalhada os direitos e deveres dos pais em relação aos filhos, inclusive, dispõe sobre as autorizações para realizações de atos e para atuar em juízo.

Da mesma forma, com relação aos bens dos menores, a legislação traz as regras de forma pormenorizada nos artigos 287 a 292 do Código Civil Argentino quanto ao usufruto dos bens dos menores pelos pais e nos artigos 293 a 304 do Código Civil a forma de administração, que, inicialmente pertence aos pais, de forma conjunta, podendo existir acordo quanto à administração exclusiva de um deles, necessitando, contudo do consentimento do outro para os atos de administração e, na falta de aocordo, poderão solicitar que o juiz nomeie o administrador ${ }^{309}$.

No direito argentino, como visto, não há previsão expressa na legislação quanto às famílias reconstituídas, que recebem tratamento enquanto fenômeno social, denominadas 'famílias ensambladas'. Há uma expressiva construção doutrinária, destacando a função social da família, que exige a adoção de marcos normativos para efetivar a tutela jurídica deste tipo familiar.

A denominação 'familias ensambladas' provém da linguagem musical, segundo a Dra. Maria Silvia Dameno. Esclarece a autora que os 'ensambles' são obras musicais escritas para um grupo de solistas e a palavra não apenas se refere ao conjunto musical como também descreve o grau de coerência com a execução musicial, e o resultado do esforço de todos, proporciona algo harmônico e gratificante tanto para os músicos como para o auditório ${ }^{310}$. Esta metáfora se popularizou e foi adotada pela doutrina.

Segundo Cecília Grosman e Inês Arcolta “a sociedade está obrigada a fixar certas regras mínimas que afirmem o compromisso daqueles que vivem com filhos, sejam ou não seus pais"311

Tampoco pueden, antes de haber cumplido 18 años de edad, ejercer oficio, profesión o industria, ni obligar sus personas de otra manera sin autorización de sus padres.

${ }^{309}$ Art.294.- La administración de los bienes de los hijos será ejercida en común por los padres cuando ambos estén en ejercicio de la patria potestad. Los actos conservatorios pueden ser otorgados indistintamente por el padre o la madre.

Los padres podrán designar de común acuerdo a uno de ellos administrador de los bienes de los hijos, pero en ese caso el administrador necesitará el consentimiento expreso del otro para todos los actos que requieran también la autorización judicial. En caso de graves o persistentes desacuerdos sobre la administración de los bienes, cualquiera de los padres podrá requerir al juez competente que designe a uno de ellos administrador.

${ }^{310}$ DAMENO, Maria Silvia. Mujeres em famílias ensambladas.

${ }^{311}$ GROSMAN, Cecília P. ALCORTA, Inês Martinez. Familias Ensambladas, Buenos Aires, 2000, pág. 134. 
Em maio de 2008, o senador Daniel Filmus, ex- Ministro da Educação apresentou o projeto de lei $n^{\circ} 1.299 / 08$, que propõe normas protetoras aos filhos das famílias reconstituídas para que pais afins tenham direitos e obrigações sobre os filhos biológicos de seus atuais companheiros, chamado: "Normas protectoras de los hijos en las familias ensambladas". O projeto foi aprovado no Senado no dia 02/12/2009 ${ }^{312}$.

312 Projeto de lei 1299/08. NORMAS PROTECTORAS DE LOS HIJOS EN LAS FAMILIAS ENSAMBLADAS. ARTICULO $1^{\circ}$ : Modifícase el artículo 198 del Código Civil el que quedará redactado de la siguiente forma: Articulo 198. Los esposos se deben mutuamente fidelidad, asistencia y alimentos. La obligación de asistencia mutua comprende el deber de un cónyuge de apoyar al otro de manera apropiada en el ejercicio de la pátria potestad respecto de los hijos propios anteriores a esta unión, y representarlo cuando las circunstancias lo exijan. ARTICULO 2: Modifícase el artículo 264 inciso 3 del Código Civil el que quedará redactado de la siguiente forma: Inciso 3: En caso de muerte de uno de los padres, ausencia com presunción de fallecimiento, privación de la patria potestad o suspensión de su ejercicio, al otro. Si por el interés superior del niño resultare a criterio judicial conveniente, se podrá asignar su ejercicio al padre o madre afín. El hijo siempre será oído y se valorará su opinión de acuerdo a su grado de madurez. El padre biológico conservará la titularidad de la patria potestad. ARTíCULO 3: Incorpórase el inciso 7 al articulo 264 del Código Civil, el que quedará redactado de la siguiente manera: Artículo 264, inciso 7: En los casos de ausencia, muerte o inhabilidad del progenitor que no ejerce la patria potestad del hijo, el padre o madre afín podrá asumir conjuntamente con el progenitor a cargo del niño dicho ejercicio. Este acuerdo debe ser homologado judicialmente, debiendo oírse en todos los casos al menor de edad. En caso de conflicto prima la opinión del progenitor. Este ejercicio se extinguirá con la ruptura del matrimonio. ARTICULO 4: Modificase el artículo 265 del Código Civil el que quedará redactado de la siguiente forma: Artículo 265: Los hijos menores de edad están bajo el cuidado de sus padres. Tienen éstos la obligación y el derecho de criar a sus hijos, 2 alimentarlos y educarlos conforme a su condición y fortuna, no solo con los bienes de los hijos, sino con los suyos propios. La madre o padre afín cooperarán en el cuidado y educación de los hijos propios del otro, y podrán cumplir todos los actos usuales relativos a la crianza y formación del niño atinentes al âmbito doméstico, como así también adoptar decisiones en caso de urgencia. Esta colaboración no afectará los derechos de los titulares de la pátria potestad. ARTICULO 5: incorpórase el artículo 265 bis, que quedará redactado de la siguiente manera: Artículo 265 bis: El progenitor a cargo del hijo podrá delegar al padre o madre afín el ejercicio de la patria potestad cuando no estuviere em condiciones de cumplir la función en forma plena por razones de viaje, enfermedad o incapacidad transitoria, y siempre que existiera imposibilidad para su desempeño por parte del otro progenitor, o no fuere conveniente a criterio judicial que este último asumiera su ejercicio. Esta delegación requerirá la homologación judicial salvo que el otro progenitor expresara su acuerdo de manera fehaciente. El hijo siempre será oído y se valorará su opinión de acuerdo a su grado de madurez. ARTICULO 6: Modifícase el artículo 266 del Código Civil el que quedará redactado de la siguiente forma: Artículo 266: Los padres e hijos se deben mutuo respeto, y en esse marco los hijos deben obedecerlos y prestar a sus progenitores la colaboración propia de su edad. Esta norma regirá igualmente para padres e hijos afines. ARTICULO 7: Modificase el artículo 363 del Código Civil el que quedará redactado de la siguiente forma: Artículo 363: La proximidad del parentesco por afinidad se cuenta por el número de grados en que cada uno de los cónyuges estuviese con sus parientes por consanguinidad. En la línea recta, sea descendente o ascendente, el yerno o nuera están recíprocamente con el suegro o suegra, en el mismo grado que el hijo o hija, respecto del padre o madre, y así en adelante. En la misma línea colateral, los cuñados o cuñadas entre sí están en el mismo grado que entre si están los hermanos o hermanas. Si hubo un precedente matrimonio, el padre o madre afín en relación a los hijos afines, están recíprocamente en el mismo grado en que el suegro o suegra en relación al yerno o nuera. ARTICULO 8: Modificase el artículo 368 del Código Civil el que quedará redactado de la siguiente forma: ARTíCULO 368: Entre los parientes por afinidad únicamente se deben alimentos aquellos que están vinculados en primer grado. La obligación alimentaria del padre o madre afín respecto de los hijos 3 afines, tendrá carácter subsidiario y no deberán prestarlos si existen parientes biológicos en condiciones de hacerlo. Igualmente, cesara la obligación en los casos de disolución del vínculo que dio origen a la afinidad. Si el padre afín hubiera asumido durante la convivencia el sustento del hijo del cónyuge podrá fijarse una cuota asistencial a cargo del padre o madre afín con carácter transitorio, cuya duración definirá el juez, si el cambio de situación pudiera ocasionar un grave daño al niño o adolescente. ARTICULO 9: Modificase el artículo 390 del Código Civil el que quedará redactado de la siguiente forma: ARTíCULO 390: La tutela legal corresponde a los abuelos, tíos, hermanos o medio 
Segundo os autores do projeto a importância reside na ausência de leis que reconheçam e amparem os pais afins nas famílias reconstituídas. Como fundamento, o projeto recorre a uma instituição existente no Código Civil Argentino, o parentesco por afinidade, para estabelecer as relações entre pais e filhos afins.

Justifica-se a importância das alterações propostas em razão do expressivo numero de novas famílias formadas após o divórcio, estabelendo novos vínculos entre os membros, que, até há pouco tempo, sequer possuíam um nome.

Busca-se a alteração do artigo 198, que agregaria a obrigação do cônjuge apoiar o outro no exercício do pátrio poder com relação aos filhos de uniões anteriores e representá-los quando as circunstâncias o exijam.

O projeto visa a que os pais afins cooperem com o cuidado e educação dos filhos afins, podendo cumprir todos os atos usuais relativos à criança e formação do menor, atinentes ao âmbito doméstico, facilitando, assim, a vida cotidiana. A norma possibilita que os pais afins tomem decisões, em caso de emergência (alteração do artigo 265 do Código Ccvil Argentino), visando à segurança do menor e, na ausência ou incapacidade transitória do genitor, este poderá delegar ao pai afim o pátrio poder (alteração artigo 265 bis).

O projeto permite que os pais afins obtenham, em conjunto com o cônjuge, o pátrio poder dos filhos da união anterior se o pregenitor tiver falecido ou estiver ausente ou, ainda, com algum tipo de incapacidade (alteração artigo 264 do Código Civil Argentino). E, em caso de morte dos progenitores, que a tutela possa ser atribuída ao pai afim, se no interesse superior do filho (alteração artigo 264 do Código Civil Argentino).

Como visto, a legislação argentina vem avançando, buscando proteger e amparar as diversas formas de constituição familiar, especialmente, os integrantes das famílias reconstituídas, os pais e filhos afins, reconhecendo-os e outorgando-lhes o mínimo de direitos e deveres, visando a facilitar a vida cotidiana e o funcionamento harmônico do lar familiar.

hermanos del menor de edad, sin distinción de sexos, y al padre o madre afín que hubiere convivido con el niño y se hubiera hecho cargo de su sustento y educación. ARTICULO 10: Comuníquese al Poder Ejecutivo. Daniel F. $\quad$ Filmus. $\quad$ Encontrado no http://senado.gov.ar/web/proyectos/verExpe.php?origen=S\&tipo=PL\&numexp=, acesso em 14/12/2009. 


\section{IX - CONCLUSÃO}

A construção da família contemporânea baseada no afeto é um fato social. A família hoje se identifica pela comunhão de vidas, de amor e de afeto no plano da igualdade, da liberdade, da solidariedade, e da responsabilidade recíproca entre os seus membros.

O legislador do Código Civil de 2002, de forma inovadora ampliou o vínculo de parentesco, ao prever, no artigo 1.593 do Código Civil, que o parentesco é natural ou civil, conforme resulte de consanguinidade ou "de outra origem", abrindo espaço para o surgimento de uma nova classe, a socioafetiva. Através da parte final do dispositivo "ou outra origem", o legislador permitiu que se realizasse, com base nos princípios constitucionais, interpretação para o reconhecimento do vínculo de parentesco por afetividade. Tal avanço é de grande importância, posto que o parentesco ao determinar o lugar das pessoas no contexto familiar, cria direitos e deveres entre os parentes e consequentemente gera efeitos pessoais e patrimoniais.

Na Jornada de Direito Civil, realizada em junho de 2002, aprovou-se proposição no sentido de que "no fato jurídico do nascimento, mencionado no art. 1.603, compreende-se, à luz do dispositivo 1.593, a filiação consanguínea e também a socioafetiva". 
A paternidade hoje deve ser entendida como aquela que decorre da estabilidade dos laços afetivos construída no cotidiano de pai e filho. Pai é aquele que convive, cuida, ama, protege, ensina, orienta e forma, enfim, pai é aquele que põe em prática a concretização dos direitos fundamentais dos filhos.

No estágio em que se encontram as relações familiares, a harmonização entre os direitos da personalidade e a plena garantia do desenvolvimento da dignidade da pessoa humana dos membros da família só podem fundar-se no valor jurídico do afeto.

Afeto, para a Psicanálise entendido como um estado emocional, capaz de afetar o indivíduo, ou seja capaz de produzir sentimentos que possibilitem a formação de um elo entre o indivíduo com outras pessoas. Relevante, pois, a qualidade dos elos mantidos pelo indivíduo que permearão os seus relacionamentos. Reside aí, a importância das relações familiares, a partir das quais o indivíduo se constituirá.

Sob o viés do Direito, o afeto pode ser entendido como elo formador e mantenedor de relações estabelecidas entre as pessoas, no âmbito familiar, que seja por relações de conjugalidade, de paternidade ou parentesco, que viabiliza a valorização das pessoas e de seus interesses tanto individuais como, enquanto parte de um grupo familiar, fundamental no desenvolvimento e formação do indivíduo.

O legislador não pode ignorar esta realidade. O instituto jurídico familiar identificado como paternidade socioafetiva, deverá integrar o nosso ordenamento jurídico, pois só assim estará em sintonia com os princípios constitucionais da dignidade da pessoa humana, da solidariedade e do melhor interesse do filho, pois só assim se concretizará a mais importante de todas as formas jurídicas de paternidade, onde seguirão como filhos legítimos os que descendem do amor e dos vínculos puros de espontânea afeição, tendo por vezes significado mais profundo que a verdade biológica.

Os pais, para os filhos menores, são muito mais importantes enquanto executores de uma função, buscando o seu pleno desenvolvimento, do que como referência biológica.

Neste contexto, estudamos as complexas relações estabelecidas nas famílias reconstituídas, assim entendidas como aquelas em que pelo menos um dos cônjuges ou companheiros possui filhos de uma união anterior.

Como vimos, através dos dados estatísticos levantados, especialmente em razão da alteração comportamental da sociedade, que passou a aceitar o divórcio com maior naturalidade, é expressivo o número de crianças crianças criadas em lares 
reconstituídos, o que justifica o estudo da estrutura, funcionamento e relações interpessoais dos integrantes das famílias reconstituídas.

Inicialmente com a nova união dos pais biológicos, estabelece-se uma relação de parentesco por afinidade entre os filhos e o novo cônjuge ou companheiro dos pais.

Com o decorrer do tempo, o pai ou mãe sem ser de sangue se torna afim não só pelo parentesco mas pela afetividade, pela convivência diária, pela solidariedade, pelos laços afetivos.

Contudo a estrutura da família reconstituída implica a fusão de duas ou mais famílias com características e modos de relação diferentes em que circulam e convivem crianças e adolescentes de distintos casamentos e convivências, criando múltiplos vínculos. Necessária, pois, constante integração, consenso, diálogo e estabelecimento de novas regras e rotinas entre os integrantes do grupo para o adequado funcionamento da nova estrutura familiar.

Não há dúvidas que a estrutura complexa das famílias reconstituídas requer um modelo distinto de funcionamento para a plena integração do novo grupo familiar. Lembramos que, muitas vezes, pais e mães afins, assumem funções dentro da família, antes mesmo que os vínculos entre os membros esteja estabelecido. De rigor, pois, a criação de um espaço próprio aos pais e mães afins pelo ordenamento jurídico.

A autoridade parental, enquanto complexo de atributos envolvidos na relação de parentalidade, possui como função mais relevante, a defesa do interesse dos filhos, para que se desenvolvam adequadamente.

Autoridade que é múnus dos pais biológicos, mas, que, inevitavelmente é desenvolvida dentro do ambiente familiar, por aqueles que convivem com o menor em razão da própria convivência e do cotidiano.

Até porque, na sociedade pós-moderna, plural quanto a sua origem e formação, diversos são os arranjos familiares possíveis, com distintas figuras de autoridade. Nestas circunstâncias os pais afins, nas famílias reconstituídas, em determinadas situações, ainda que de forma complementar aos pais biológicos, auxiliarão da criação e educação do menor.

Enquanto autoridade dentro do ambiente familiar, representam o outro adulto da casa, os pais afins, direta ou indiretamente, irão desenvolver funções parentais, seja transmitindo valores, seja nos cuidados domésticos, seja opinando quanto a aspectos 
variados do grupo familiar, o fator variante de uma família para a outra, será tão somente a intensidade deste exercício.

Somente o exercício pleno da autoridade parental, de forma integrativa a dos pais biológicos, nos lares reconstituídos permitirá uma adequada estruturação familiar, assim, tendo seus membros suas funções definidas, propiciarão melhores condições para o desenvolvimento dos menores, no seio da nova família.

Não há dúvida, portanto, quanto à possibilidade de exercício da autoridade parental pelo genitor afim, mediante autorização do titular.

O que se pretende dizer é que o poder familiar é, de fato, exercido pelo pai original, pela mãe original e também pelo novo companheiro ou novo cônjuge em família reconstituída. Isso é decorrência da natureza dinâmica das relações sociais, funcionais e afetivas nas entidades familiares e que, apesar da determinação do artigo 1.636 do CCB 2002 em sentido contrário, as situações cotidianas mostram outra realidade.

É melhor a criança ter dois pais a não ter a figura paterna.

A convivência faz gerar inúmeras situações envolvendo a família sendo impossível que o novo marido ou mulher simplesmente se mantenha alheio a respeito das decisões relativas aos filhos de seu cônjuge ou companheiro.

Cumpre esclarecer, no entanto, que a origem da família reconstituída influencia no papel dos pais afins, pois se o pai biológico faleceu, o pai afim poderá mais facilmente exercer o papel de "pai", preenchendo um vazio na vida daquele menor, entretanto, quando a família reconstituída é proveniente da separação dos pais biológicos, a atuação do pai afim será diferente e complementar, dependendo do grau de atuação do pai biológico.

Se os pais biológicos são ativos, os pais afins não substituem e nem devem substituir estes, principalmente se a participação for efetiva na criação e educação do menor. Se ausentes, pode dar-se a lógica substituição por se encontrar vago o lugar do pai.

Por certo, nestas situações, ainda que mantidos os laços originais de paternidade, não há como ignorar o exercício da autoridade parental pelos pais afins, uma vez que a convivência familiar pressupõe a transmissão de valores e princípios e a participação na vida do grupo. Do mesmo modo, tratando-se o cônjuge ou o companheiro do pai ou da mãe, de outro adulto da casa, em diversas situações cotidianas, desde os cuidados com a alimentação até o socorro em caso de algum acidente, será o pai ou mãe afim que atuará como autoridade dentro do ambiente familiar. 
É óbvio que nesta situação a atuação é subsidiária, com vistas a integrar a parentalidade, auxiliando no desenvolvimento do menor, sendo, pois, limitada pelo cônjuge ou companheiro genitor. As relações, nestas circunstâncias, exigirão constantes esforços dos participantes visando à conciliação entre pais e filhos biológicos e afins.

Não são raros os casos que pais afins assumem integralmente a paternidade daquele menor, que, em razão da convivência e baseado na afetividade, firmou-se verdadeiro vínculo paterno-filial, decorrente da posse de estado de filho.

A família, hoje, dentro do contexto pluralista, deve ser vista como instrumento para o desenvolvimento da personalidade de seus integrantes, não importando se se distancia do modelo institucional, desde que contribua para a realização da dignidade dos seus participantes.

Neste passo, o direito deverá reconhecer a existência dos pais e mães afins, no âmbito das famílias reconstituídas, regulamentando-a apropriadamente, visando à afirmação da posição dos integrantes das famílias reconstituídas, e, especialmente, dandolhes legitimidade para colaborar no cuidado do filho afim.

A nossa legislação civil é omissa, na medida em que não legitima a atuação dos pais afins. Deste modo, não se exerce a completa proteção dos entes familiares, não se estimula os compromissos e nem as responsabilidades dentro das famílias reconstituídas. Ao contrário, o artigo 1.636 do Código Civil, ignora e veda o exercício da parentalidade pelos pais afins.

É primordial que se reconheça o lugar dos pais afins dentro da família reconstituída e a importância de sua função subsidiária, enquanto executores de uma parentalidade integrativa à dos pais biológicos, legitimando-se, pois, suas condutas. Pois, só assim, estar-se-á cumprindo o preceito constitucional do melhor interesse do menor.

Enquanto não reconhecida a legitimidade para o desempenho da função de parentalidade pelos pais afins, importante que os operadores do direito se orientem pelos mandamentos constitucionais, como normas de eficácia imediata, para a realização dos princípios do melhor interesse do menor, tendo em vista o seu pleno desenvolvimento, integrado no seio de sua família. É certo que doutrina e jurisprudência têm reconhecido o caráter normativo de princípios como o da solidariedade social, da dignidade da pessoa humana, entre outros, aos quais se tem assegurado eficácia imediata nas relações de direito civil. Somente, assim, através de recursos interpretativos, serão preservados os valores constitucionais e os princípios fundamentais da pessoa humana. 


\section{X - BIBLIOGRAFIA}

ALMEIDA, José Luiz Gavião. O Direito de Família e a Constituição de 1988. In: Carlos Alberto Bittar. (Org.). O Novo Estatuto da Filiação, Ed. Saraiva, São Paulo, 2003, pág. $153 / 186$.

ALMEIDA, Maria Christina. A Paternidade Sócioafetiva e a Formação da Personalidade. O Estado e os Estados de Filiação. Revista Jurídica Del Rey, Belo Horizonte, Ed. Del Rey/IBDFAM, 2002, n. 8, p. 24, maio 2002. (Número especial).

ALVES, José Carlos Moreira. Direito Romano. 14ª edição, Ed. Forense, 2008.

AMORIM, Maria João. Família: crise ou transformação? Disponível em http://www.apfn.com.pt/noticiais/out2004/011004a, acesso em 17/11/2009.

ASCENSÃO, José de Oliveira. O Direito: introdução e teoria geral. Uma perspectiva lusobrasileira, Lisboa. Calouste Gulbenkian, 1978.

ASSUMPÇÃO, Luiz Roberto de. Aspectos da Paternidade no novo Código Civil. São Paulo: Saraiva, 2004.

AZEVEDO, Álvaro Villaça. Estatuto da Família de Fato. Ed. Atlas, 2a edição, São Paulo, 2002.

BARBOZA, Heloisa Helena, O reconhecimento jurídico. Del Rey. Revista jurídica, a 4, n. 8, p. 23, maio 2002. 
BARROS, Fernanda Otoni de. Paternidade. Do Direito do Pai: sobre a Paternidade no Ordenamento Jurídico. Revista Brasileira de Direito de Família. Porto Alegre: Síntese/IBDFAM, v. 6, p. 21, jul./ago./set. 2000.

BARROS, Sérgio Resende de. A ideologia do afeto. Revista Brasileira de Direito de Família. Porto Alegre: Síntese, Jul-Ago-Set. 2002, v. 14, p. 9.

BITTAR, Eduardo C.B. O Direito na pós-modernidade. Rio de Janeiro. Forense Universitária, 2005.

BITTENCOURT. Edgard de Moura. Família. $5^{\text {a }}$ ed., rev., atual. e ampliada por Joaquim Macedo Bittencourt Netto e Antônio Carlos Mathias Coltro, Campinas, Ed. Millennium, 2003.

BOEIRA, José Bernardo Ramos. Investigação de Paternidade, Posse do Estado de Filho: Paternidade sócioafetiva. Porto Alegre : Livraria do Advogado, 1999.

BONFANTE, Pietro. Instituizione di Diritto Romano, $1^{\mathrm{a}}$ ed., ristampa della X edizione, Torino, 1946. . Corso di Diritto Romano I, Diritto di Famiglia, reimpressão, Milano, 1963.

BRAUNER, Maria Cláudia Crespo. Novos Contornos do Direito de Filiação: a Dimensão Afetiva das Relações Parentais. Revista da AJURIS, Porto Alegre : Associação dos Juízes do Rio Grande do Sul, v. 26, n. 78, p. 193-216, jun. 2000.

. Reinventando o direito de família: novos espaços de conjugalidade e parentalidade. Revista Trimestral de Direito Civil, v. 18, p. 79-107, ANO BRUNO, Denise Duarte. Família sócioafetiva. Revista Jurídica Del Rey, Belo Horizonte : Del Rey/IBDFAM, n. 8, p. 27, maio 2002. (Número especial).

CAMBI, Eduardo. O Paradoxo da Verdade Biológica e Sócio-Afetiva na Ação Negatória de Paternidade, Surgido com o Exame do DNA, na Hipótese de "Adoção à Brasileira". Jornal Síntese, Porto Alegre, v. 59, jan. 2002. p. 19.

CARBONERA, Silvana Maria. O Papel Jurídico do Afeto nas Relações de Família. In: FACHIN, Luiz Edson. (coord.). Repensando Fundamentos do Direito Civil Brasileiro Contemporâneo. Rio de Janeiro: Renovar, 1998.

CARNEIRO, Sérgio Barradas. Projeto de Lei $n^{\circ}$ 674/2007. Dispõe sobre o Estatuto das Famílias. Projeto de lei apresentado e atualmente em trâmite na Câmara dos Deputados, Brasília, 2007.

CARTER, B \& MC GOLDRICK, M. As mudanças no ciclo de vida familiar: uma estrutura para terapia familiar, Porto Alegre, Artes Médicas, 1995. 
CHAVES, Antonio. Comentários ao Estatuto da Criança e do Adolescente, São Paulo, ED. LTR, 2006.

CIAN, Giorgio. OPPO, Giorgio, TRABUCCHI, Alberto. Comentario al diritto italiano della famiglia, v.4, Cedam, Padova, 1992.

CHINELATO, Silmara Juny de Abreu. Comentários ao Código Civil. Parte Especial. Do Direito de Família. Coordenação Antonio Junqueira de Azevedo. Ed. Saraiva. São Paulo, 2004.

. Exame de DNA, filiação e direitos da personalidade.

In: LEITE, Eduardo Silveira. (Org.). DNA como meio de prova da filiação: aspectos constitucionais, civis e penais. Rio de Janeiro: Forense, 2000, v. , p. 331-364.

CLARIN (Jornal argentino, 'on-line'). http://clarin.com/diario/2008/06/08/sociedad/s-04015.htm, acesso em 02/10/2009.

COLTRO, Antônio Mathias. Um valor imprescindível. Revista Jurídica, a.4, nº 08, Ed. Del Rey, Belo Horizonte, 2002.

COMEL, Denise Damo. Do Poder Familiar. Ed. RT, São Paulo, 2003.

CODIGO CIVIL DE LA REPUBLICA ARGENTINA. Disponível em http://www.redetel.gov.ar/Normativa/Archivos\%20de\%20Normas/CodigoCivil.htm, acesso em 19/11/2009.

CÓDIGO CIVIL DE CHILE. Disponível em http://www.paginaschile.cl/biblioteca_juridica/codigo_civil/codigo_civil_de_chile.htm, acesso em 19/11/2009.

CONSTITUIÇÃO ALEMÃ TRADUZIDA PARA A LÍNGUA ESPANHOLA. Disponível no site da Embaixada Alemã no Brasil: http://www.brasilia.diplo.de/Vertretung/brasilia/pt/01_Deutschland/Constituicao/grundges etz_seite.html, acesso em 15/11/2009.

CONSTITUIÇÃO DA REPÚBLICA PORTUGUESA - VII Revisão Constitucional. Disponível em http://www.parlamento.pt/RevisoesConstitucionais/Documents/Revisao2005/155a00.pdf,, acesso em 30/11/2009.

LA CONSTITUZIONE ITALIAN. Disponível em http://www.cjf.gov.br/Bvirtual/asp/saidaCat.asp?cod=9codintermed=18\&id=ita, acesso em 07/12/2009. 
CONSTITUICIÓN POLÍTICA DE LA REPUBLICA DEL CHILE. Decreto $\mathrm{n}^{\circ}$ 1.150/1980. Ministerio del Interior. Disponível em http://www.direito.adv.br/constitu.htm, acesso em 19/11/2009.

CONSTITUICIÓN DE LA NACIÓN ARGENTINA. Disponível em http://www.direito.adv.br/constitu.htm, acesso em 19/11/2009.

CORNU, Gerard. Droit Civil: La Famille. $8^{a}$ édition. Paris, Montchestien, 2003, pág. 324/326.

CORRÊA, Carlos Pinto. O Afeto no Tempo. Disponível em http://www.cbp.org.br/rev2806.htm, acesso em 07/10/2009.

Constituición de la Nación Argentina. Disponível em http://www.direito.adv.br/constitu.htm, acesso em 19/11/2009.

DAMENO, Maria Silvia. Mujeres en famílias ensambladas, Buenos Aires.

DAVISON. Dora. Las famílias ensambladas, en qué se diferencian?

DELGADO, Mario Luiz e ALVES, Jones Figueiredo. Questões Controvertidas no Direito de Família e das Sucessões. Série Grandes Temas de Direito Privado, vol. III, Ed. Método, 2006.

DI MARZO, Istituzioni di diritto romano. 5.ed. Milano: A. Giuffre, 1946.

DIAS, Maria Berenice. Direito das famílias. $2^{\mathrm{a}}$ ed., Porto Alegre: Ed. Livraria do Advogado, 2005.

. Famílias Plurais. Manual de Direito das Famílias, Ed. RT, $5^{\text {a }}$ edição, São Paulo, 2009, pág. 40 a 55.

- Comentários - Família pluriparental, uma nova realidade.

Disponível em http://www.lfg.com.br. 29 de dezembro de 2008, acesso em 17/11/2009.

DIAS, Maria Berenice e BASTOS, Eliene Ferreira. Família além dos mitos. Ed. Del Rey, Belo Horizonte, 2008

DIAS, Maria Berenice. PEREIRA, Rodrigo da Cunha (coord.). Direito de Família e o novo código civil. Belo Horizonte, Del Rey, 2005.

DINIZ, Maria Helena. Curso de Direito Civil Brasileiro. Direito de Família. 20.ed. São Paulo : Saraiva, 2005. v.5.

. Código Civil Anotado, $9^{\mathrm{a}}$ ed. atual. São Paulo, Saraiva.

DUARTE, Lenita Pacheco Lemos. A guarda dos filhos na família em litígio - Uma interlocução da psicanálise com o Direito. Ed. Lúmen Júris, 2006.

EIRANOVA ENCINAS, Emilio. COESTER-WALTJEN, Dagmar. Código Civil alemán comentado: BGB, Marcial Pons, Ediciones Jurídicas y Sociales, Madrid, 1998. 
ELIAS, Roberto João. Pátrio Poder: guarda dos filhos e direito de visita. Ed. Saraiva, 1999. Comentários ao Estatuto da Criança e do Adolescente Lei $n^{\text {o }}$ 8.069, de 13 de julho de 1990. $2^{\text {a }}$ ed. Saraiva, 2004, São Paulo. . Direitos Fundamentais da Criança e do Adolescente. Ed.

Saraiva, 2005. São Paulo.

ESTATÍSTICAS DO GOVERNO BRITÂNICO. Dados disponíveis no site HTTP://www.statistics.gov.uk, acesso em 29/09/2009.

FACHIN, Luiz Edson. Direito de Família. 2a. ed. Rio de Janeiro: Renovar, 2003. - Estabelecimento da Filiação e Paternidade Presumida. Porto Alegre: Sérgio Antônio Fabris, 1992. Limites e Possibilidades da Nova Teoria Geral do Direito Civil. Revista de Estudos Jurídicos, v. II, n. 1, ago. 1995.

A Tríplice Paternidade dos Filhos Imaginários. ALVIM, Teresa Arruda (coord). Repertório de Jurisprudência e Doutrina sobre Direito de Família: Aspectos Constitucionais, Civis e Processuais. São Paulo : Revista dos Tribunais, 1998. v. 2. .LIRA, Ricardo Pereira (coord.). in Elementos Críticos do Direito de Família: Curso de Direito Civil. Rio de Janeiro : Renovar, 1999.

. Comentários ao Novo Código Civil. Do Direito de Família. Do direito pessoal. Das Relações de Parentesco. Arts. 1.591 a 1.638. Vol. XVIII - Coord. Sávio de Figueiredo Feitosa $-1^{\mathrm{a}}$ edição. Rio de Janeiro: Forense, 2003.

- Princípios constitucionais do direito de família brasileiro contemporâneo. In. DIAS, Maria Berenice e BASTOS, Eliene Ferreira. Família além dos mitos. Ed. Del Rey, Belo Horizonte, 2008, pág. 121/130.

FARIA, Cristiano Chaves. A família da pós-modernidade: mais que fotografia, possibilidade de convivência. Disponível em http://www.juspodivm.com.br/novo/arquivos/artigos/civil_família/artfamilia4.pdf, acesso em 07/01/2009.

FELIPE, J. Franklin Alves; ALVES, Geraldo Magela. O Novo Código Civil Anotado. Colaborador João Bosco Cascardo de Gouvêa. Rio de Janeiro : Forense, 2002.

FERREIRA. Aurélio Buarque de Holanda. Novo Aurélio dicionário da Língua Portuguesa. $3^{\text {a }}$ ed. rev. e ampliada - Rio de Janeiro: Nova Fronteira, 1999.

FILMUS, Daniel F. Projeto de lei 1299/08. Normas protectoras de los hijos en las familias ensambladas.

Disponível em 
http://senado.gov.ar/web/proyectos/verExpe.php?origen=S\&tipo=PL\&numexp=, acesso em 14/12/2009.

FRANÇA, Rubens Limongi. Instituições de Direito Civil. São Paulo: Saraiva, 1988. . Manual de Direito Civil.São Paulo: RT, 1972, vol. 2, t.I.

FUJITA, Jorge Shiguemitsu. Curso de Direito Civil. Direito de Família. Ed. Juarez de Oliveira. São Paulo, 2003.

GAMA, Guilherme Calmon Nogueira. Das relações de parentesco. In, DIAS, Maria Berenice; PEREIRA, Rodrigo da Cunha. Direito de Família e o novo código Civil, Belo Horizonte. Del Rey, 2001, p. 87/88.

GIRARDI, Viviane. Famílias Contemporâneas, Filiação e Afeto - a possibilidade Jurídica da Adoção por Homossexuais. Porto Alegre: Livraria do Advogado, 2005.

GOMES. Orlando. Direito de Família. 14ª ed., Rio de Janeiro: Forense, 2002.

GOMES, Isabel Cristina. Relacionamento: os meus, os seus, os nossos ... A arte da convivência pacífica! Disponível em http://www.ip.usp.br/docentes/isagomes/\%5Cpdf\%5Cartgrelacionamento.pdf, acesso em $10 / 11 / 2009$.

GRISARD FILHO, Waldyr. Famílias reconstituídas. Novas uniões depois da separação. Ed. Revista dos Tribunais. São Paulo, 2007,

Famílias Reconstituídas. Novas relações depois das separações. Parentesco e autoridade parental. In. Afeto, Ética, Família e o Novo Código Civil Brasileiro. Anais do IV Congresso Brasileiro de Direito de Família - IBDFAM, coorenador Rodrigo da Cunha Pereira, Ed. Del Rey, Belo Horizonte, 2004, pág. 657 a 675. - Os alimentos nas famílias reconstituídas. In. Questões Controvertidas no novo Código Civil, corrd. Mário Luiz Delgado e Jones Figuerêdo Alves, Série Grandes temas de Direito privado - vol. 1, Ed. Método, São Paulo, 2003, pág. 373 a 388.

GROENINGA, Giselle Câmara. Aspectos psicológicos na prática jurídica. Rio de Janeiro: Imago, 2003.

. Afetos, sexualidade e violência - A família desmistificada.

In. DIAS, Maria Berenice e BASTOS, Eliene Ferreira. Família além dos mitos. Ed. Del Rey, Belo Horizonte, 2008, pág. 67/80.

GROSMAN, Cecília P. La multiplicidad de formas de familia. La família monoparental y la família ensamblada. Documento de trabajo presentado en las jornadas teórico praticas: 
família y derechos fundamentales, realizada los dias 8 y 9 de marzo del 2006 en la Universidad Catolica Andres Bello, Caracas, Venezuela.

GROSMAN, Cecília P. ALCORTA, Inês Martinez. Familias Ensambladas, Buenos Aires, 2000 .

GUIMARÃES, Luís Paulo Cotrim. O direito de visitação do pai não-biológico. Revista Trimestral de Direito Civil, v. 2, ano 1, p. 95-102, abr./jun. 2000.

GUIMARÃES, Luís Paulo Cotrim. A presunção da paternidade no casamento e na união estável in Anais do III Congresso Brasileiro de Direito de Família. Coordenador: Rodrigo da Cunha Pereira, Belo Horizonte: Instituto Brasileiro de Direito de Família - IBDFAM, 2002, p. 366.

GUSMÃO, Paulo Dourado de. Dicionário de Direito de Família. 2.ed. rev. e ampl. Rio de Janeiro : Forense. 1987.

HERRERA, Marisa. Filiación, adoptión y distintas estructuras familiares em los albores del siglo XXI. In. DIAS, Maria Berenice e BASTOS, Eliene Ferreira. Família além dos mitos. Ed. Del Rey, Belo Horizonte, 2008, pág. 151/200.

HIRONAKA, Giselda Maria Fernandes Novaes. Direito ao pai. Revista Jurídica Del Rey, v. 7, p. 20, 1999.

Se eu soubesse que ele era meu pai. Revista do Instituto de Pesquisas e Estudos Divisão Jurídica, v. 27, p. 321-323, 2000.

Responsabilidade Civil na Relação Paterno-filial. Novos estudos jurídicos, v. 14, p. 69-101, 2002.

. Seus filhos e nossos filhos. News Letter, v. 1, p. 3-3, 2004.

Aspectos jurídicos da relação paterno-filial. Carta Forense, São

Paulo, v. 3, p. 3-3, 2005.

A outra face do Judiciário. São Paulo: Del Rey/ EPD, 2005.

Novo Código Civil - Interfaces no ordenamento jurídico

brasileiro. Belo Horizonte: Del Rey, 2004.

A incessante travessia dos tempos e a renovação dos paradigmas: a família, seu status e seu enquadramento na pós-modernidade. In. DIAS, Maria Berenice e BASTOS, Eliene Ferreira. Família além dos mitos. Ed. Del Rey, Belo Horizonte, 2008, pág. 49/65.

HIRONAKA, Giselda Maria Fernandes Novaes e OLIVEIRA, Euclides. Do Direito de Família. In. DIAS, Maria Berenice e PEREIRA, Rodrigo da Cunha. Direito de Família e o novo Código Civil. Ed. Del Rey, Belo Horizonte, 2001, pág. 01/10. 
HOLANDA, Aurélio Buarque de. O Dicionário da Língua Portuguesa. 3a. ed. Rio de Janeiro: Nova Fronteira, 1999.

INSTITUTO BRASILEIRO DE GEOGRAFIA E ESTATÍTICA - IBGE. Estatísticas de Registro Civil relativa ao ano de 2007, publicada em 2008, dados no site http://ibge.gov.br, acesso em 29/09/2009.

KAUFFMAN, Daniel. A Família reconstituída e o seu ciclo vital: uma análise qualitativa dos seus perfis. Monografia apresnetada ao Programa de Iniciação Científica, Faculdade de Psicologia, Universidade Presbiteriana Mackenzie, São Paulo, 2000

LACAN, Jacques. Nomes-do-Pai. Rio de Janeiro: Jorge Zahar, 2005.

Os Complexos Familiares. Rio de Janeiro: Jorge Zahar, 2002.

LEITE, Eduardo de Oliveira. Temas de Direito de Família. São Paulo, Ed. RT, 1994.

Eduardo Oliveira. Famílias Monoparentais. SP. Revista dos

Tribunais, 1997.

Procriações artificiais e o direito. São Paulo, Revista dos

Tribunais, 1995.

LISBOA. Roberto Senise. Manual Elementar de Direito Civil, vol. 5, 2 ed. Ver. E atual. Em conformidade com o novo código civil - Direito de Família e das Sucessões, São Paulo: Revista dos Tribunais, 2002.

LÔBO, Paulo Luiz Netto. A família enquanto estrutura de afeto. In. DIAS, Maria Berenice e BASTOS, Eliene Ferreira. Família além dos mitos. Ed. Del Rey, Belo Horizonte, 2008, pág. 251/258.

Do Poder Familiar. In. Direito de Família e o novo Código Civil. Ed. Del Rey, Belo Horizonte, 2001, pág. 141/153.

Direito ao estado de filiação e direito à origem genética: uma distinção necessária. Anais do IV Congresso Brasileiro de Direito de Família, coord. Rodrigo da Cunha Pereira. Belo Horizonte, Del Rey, 2004.

Princípio jurídico da afetividade. Disponível em http://jus2uol.com.br/doutrina/texto.asp?id=527, acesso em 07/01/2009.

Entidades familiares constitucionalizadas: para além dos 'numeros clausus'. Revista Brasileira de Direito de Família, v. 03, n. 12, pág. 40-55, janmar, Porto Alegre, 2002.

MAIDANA, Jédison Ronei Daltrozo. O fenômeno da paternidade socioafetiva: a filiação e a revolução da genética. Disponível no site www.ibdfam.com.br. MADALENO, Rolf Hanssen. A Multa Afetiva. Aspectos Processuais do Direito de 
Família. Revista Jurídica Del Rey, Belo Horizonte: Del Rey/IBDFAM, n. 8, p. 33, maio 2002. (Número especial).

Novas Perspectivas no Direito de Família. Porto Alegre :

Livraria do Advogado, 2000.

MANRIQUE, Ricardo C. Perez. Nuevas formas familiares - Demografía Y Derecho de Familia. In. DIAS, Maria Berenice e BASTOS, Eliene Ferreira. Família além dos mitos. Ed. Del Rey, Belo Horizonte, 2008, p. 259/273.

MARQUES, Claudia Lima; CACHAPUZ, Maria Cláudia (col.) VITÓRIA, Ana Paula da Silva (col.). Igualdade entre Filhos no Direito Brasileiro Atual - Direito Pós-Moderno? Revista dos Tribunais, São Paulo, v. 764, p. 11-32, 1999.

MONTEIRO, Washington de Barros. Curso de Direito Civil. Direito de Família. 34.ed. rev. São Paulo : Saraiva, 1997. v. 2

MORAES, Alexandre de. Direitos Humanos Fundamentais. Coleção Temas Jurídicos, $7^{\mathrm{a}}$ ed., Ed. Atlas, São Paulo, 2006.

NERY Jr; Nelson; NERY, Rosa Maria de Andrade. Código Civil Comentado. 3a. ed. São Paulo: RT, 2005.

MUNIZ, José Ferreira. O direito de família na solução dos litígios. Textos de Direito Civil, Curitiba, Juruá, 1998.

OLIVEIRA FILHO, Bertoldo Mateus de. Relacionamento Interfamilial. Interfaces e Conexões Do Direito de Família. Del Rey Revista Jurídica, Belo Horizonte : IBDFAM, 2002, n. 8, p. 32, maio. (Número especial).

OLIVEIRA, Guilherme. Critério Jurídico da Paternidade. Coimbra: Almedina, 2003, pág. 445 .

OLIVEIRA, J.L.C.; MUNIZ, F.J.F., Direito de família, Sergio Fabris Editor, Porto Alegre, 1990.

PARLEGRECO, Carlo. Dizionario Portoghese-Italiano, Italiano-Porthoguese. Ed. Martins Fontes, $5^{\text {a }}$ edição, São Paulo, 1990.

PEREIRA, Caio Mário da Silva. Instituições de Direito Civil. Rio de Janeiro : Forense, 1990, p. 417. v. 5.

PEREIRA, Rodrigo da Cunha (cord.). Afeto, Ética, Família e o Novo Código Civil. Belo Horizonte: IBDFAM/Del Rey, 2004.

. Direito de Família - Uma abordagem Psicanalítica. 3a. ed. Belo

Horizonte: Del Rey, 2003. 
Novo Código Civil da Família Anotado. Ed. Síntese, Porto

Alegre, 2003.

. Casamento, união estável, namoro e uniões homoafetivas. In.

DIAS, Maria Berenice e BASTOS, Eliene Ferreira. Família além dos mitos. Ed. Del Rey, Belo Horizonte, 2008, pág. 275/282.

PEREIRA, Sérgio Gischkow. Algumas Questões de Direito de Família na Nova Constituição. A Igualdade na Filiação, Inclusive para Adotados. Revista AJURIS, n. 45, v. 16, p. 145-154, março 1989.

PEREIRA, Tânia da Silva. Direito da Criança e do Adolescente: uma Proposta Interdisciplinar. Rio de Janeiro : Renovar, 1996.

- Famílias Possíveis: Novos paradigmasna convivência familiar. In. Afeto, Ética, Família e o Novo Código Civil Brasileiro. Anais do IV Congresso Brasileiro de Direito de Família - IBDFAM, coorenador Rodrigo da Cunha Pereira, Ed. Del Rey, Belo Horizonte, 2004, pág. 633 a 655.

PEREIRA, Helena Bonito Couto. Michaelis: dicionário escolar espanhol. EspanholPortuguês Português-Espanhol. Ed. Melhoramentos, São Paulo, 2002.

PERLINGIERI, Pietro. Codice Civile Annotato com la dottrina e la giurisprudenza. Libro primo. UTET, Torino, 1981.

. Perfis do direito civil: introdução ao direito civil constitucional,

Rio de Janeiro, renovar, 1997, p. 244.

PERROT, Michelle. Funções da Família. In: História da Vida Privada. Da Revolução Francesa à Primeira Guerra. São Paulo: Companhia das Letras, 1991. v. 4.

. O nó e o ninho. In Reflexões para o Futuro. Editora Abril. São Paulo,

1993.

PESSOA, Vilmarise Sabim. A afetividade sob a ótica psicanalítica e piagetiana. Publicatio UEPG - Ciências Humanas, 2000, pág, 97 a 107.

QUEIROZ, Juliane Fernandes. Paternidade: aspectosjurídicos e técnicas de inseminação artificial, Ed. Del Rey, Belo Horizonte, 2001

REZEK, FRANCISCO. O DIREITO À IDENTIDADE. In. DIAS, Maria Berenice e BASTOS, Eliene Ferreira. Família além dos mitos. Ed. Del Rey, Belo Horizonte, 2008, pág. 41/47

RODRIGUES, Silvio. Direito Civil. 27.ed. atual. por Francisco José Cahali, com Anotações sobre o Novo Código Civil (Lei 10.406, de 10-1-2002). São Paulo : Saraiva, 2002. v. 6. 
SALAZAR, Clarissa. Afeto, Lei e Família. Conferência apresentada na $2^{\text {a }}$ Jornada Baiana de Psicologia Jurídica - Família, Afeto e Lei: novos moldes de (en)laço, Salvador, maio de 2009.

SIMÃO, José Fernando. O valor jurídico do afeto: a arte imita a vida. A parentalidade socioafetiva e a novela. Disponível em http://www.flaviotartuce.adv.br, acesso em 26/09/2007.

SANTOS, Lia Justiniano. Guarda Compartilhada. Revista Brasileira de Direito de Família, pág. 155 a 164. Ed. Síntese, 2001, Porto Alegre.

SARLET, Ingo Wolfgang. Dignidade da Pessoa Humana e Direitos Fundamentais na Constituição Federal de 1988. Porto Alegre : Livraria do Advogado, 2001.

SILVA, Denise Maria Perissini. Famílias Reconstruídas. Trabalho apresentado no V Congresso de Psicologia Jurídica Y Forense del Caribe. Disponível em http://psicologiajuridica.org/psj270.html, acesso em 17/11/2009.

SILVA, Evani Zambon Marques da. Paternidade ativa na separação conjugal. São Paulo: Juarez de Oliveira, 2005.

SILVA, Marcos Alves da. Do pátrio poder à autoridade parental: repensando fundamentos jurídicos da relação entre pais e filhos, Ed. Renovar, Rio de Janeiro, 2002.

STEP-FAMILIES FOUNDANTION. http://www.sucessfulstepfamilies.com/view/176, acesso em 29/09/2009.

STEP-FAMILIES ORGANIZATION. http://www.stepfamily.org/statistics.htlm, acesso em 29/09/2009.

TAPIA, Manuel Bermudez. Blog. http://blog.pucp.edu.pe/item/23019, acesso em 02/10/2009.

TEIXEIRA, Ana Carolina Brochado. Família, Guarda e Autoridade Parental. Ed. Renovar, 2005 .

TEPEDINO Gustavo (Coord). in Problemas de direito civil-constitucional. O Código Civil, os chamados microssistemas e a Constituição: premissas para um reforma legislativa, Rio de Janeiro: Renovar, 2000.

Premissas Metodológicas para a Constitucionalização do Direito

Civil. In: TEPEDINO, Gustavo. Temas de Direito Civil. 2.ed. rev. e atual. Renovar. Rio de Janeiro/São Paulo : Renovar, 2001.

TIBA, Içami. Adolescente: Quem ama educa! 8a. ed. São Paulo: Integrare, 2005. VARELA, Antunes e LIMA, Pires de. Código Civil Anotado, volume V, Coimbra Edidora, Coimbra, Portugal, 1995. 
VARELA, Antunes. Direito da família. Editora Lisboa, Petrony, Portugal, 1993.

VELOSO, Zeno. Direito Brasileiro da filiação e paternidade. SP. Malheiros, 1997.

VENOSA, Silvio de Salvo. Direito de Família, Coleção Direito Civil, Vol. 6, $3^{a}$ edição, São Paulo, Atlas, 2003.

VIANA, Terezinha Camargo. ARRAES, Ana Karerina. Afeto e Dor: faces do luto na obra freudiana. Disponível em http://www.estadosgerais.org/encontro/afeto_e_dor.shtml, acesso em 07/10/2009.

VILLELA. João Baptista. Desbiologização da Paternidade. Revista Forense, jul-ago-set 1980, p. $45 / 51$.

WAGNER, Adriana e BANDEIRA, Denise R. O desenho da família: um estudo sobre adolescentes de famílias originais e reconstituídas. Trabalho apresentado no VI Simpósio de Pesquisa e IntercÇambio Científico da ANPEPP, Rio Grande do Sul, maio de 1996.

WALD, Arnoldo. O Novo Direito de Família. 13.ed. rev. atual. e ampl. pelo autor, de acordo com a Jurisprudência e com Referências ao Projeto de Código Civil, com a Colaboração do Des. Luiz Murillo Fábregas e da Prof ${ }^{a}$ Priscila M. P. Corrêa da Fonseca. São Paulo Saraiva, 2002.

WELTER, Belmiro Pedro. Investigação de paternidade sócioafetiva. Revista Brasileira de Direito de Família. Porto Alegre, Síntese/ IBDFAM, v. 6, p. 50-52, jul/ago/set. 2000. Igualdade entre as Filiações Biológica e SócioAfetiva. São Paulo : Revista dos Tribunais, 2003.

Novo Código Civil: texto comparado: código civil de 2002, código civil de 1916, organizador, São Paulo: Atlas, 2002.

WINOGRAD, Monah. SOLLERO-DE-CAMPOS, Flávia. J. LANDEIRA-FERNANDEZ. Um diálogo entre a psicanálise e a neurociência. Departamento de Psicologia, Pontificia Universidade Católica do Rio de Janeiro, 2005. Disponível em http://www.scielo.br/scielo.php?pid=S0102-37722005000100016\&script=sci_arttext, acesso em 07/10/2009. 